UNIVERSIDADE DE SÃO PAULO

Faculdade de Filosofia, Letras e Ciências Humanas

Programa de Pós-Graduação em História Social

\title{
ARMÊNIOS E GREGOS OTOMANOS A Polêmica de um Genocídio
}

\author{
(Versão Corrigida) \\ Ligia Cristina Sanchez de Almeida \\ Dissertação apresentada ao Programa de \\ Pós Graduação em História Social da \\ Faculdade de Filosofia, Letras e Ciências \\ Humanas da Universidade de São Paulo, \\ para obtenção do título de Mestre em \\ História.
}

Orientadora: Profa. Dra. Maria Luiza Tucci Carneiro 
Ligia Cristina Sanchez de Almeida

\section{ARMÊNIOS E GREGOS OTOMANOS A Polêmica de um Genocídio}

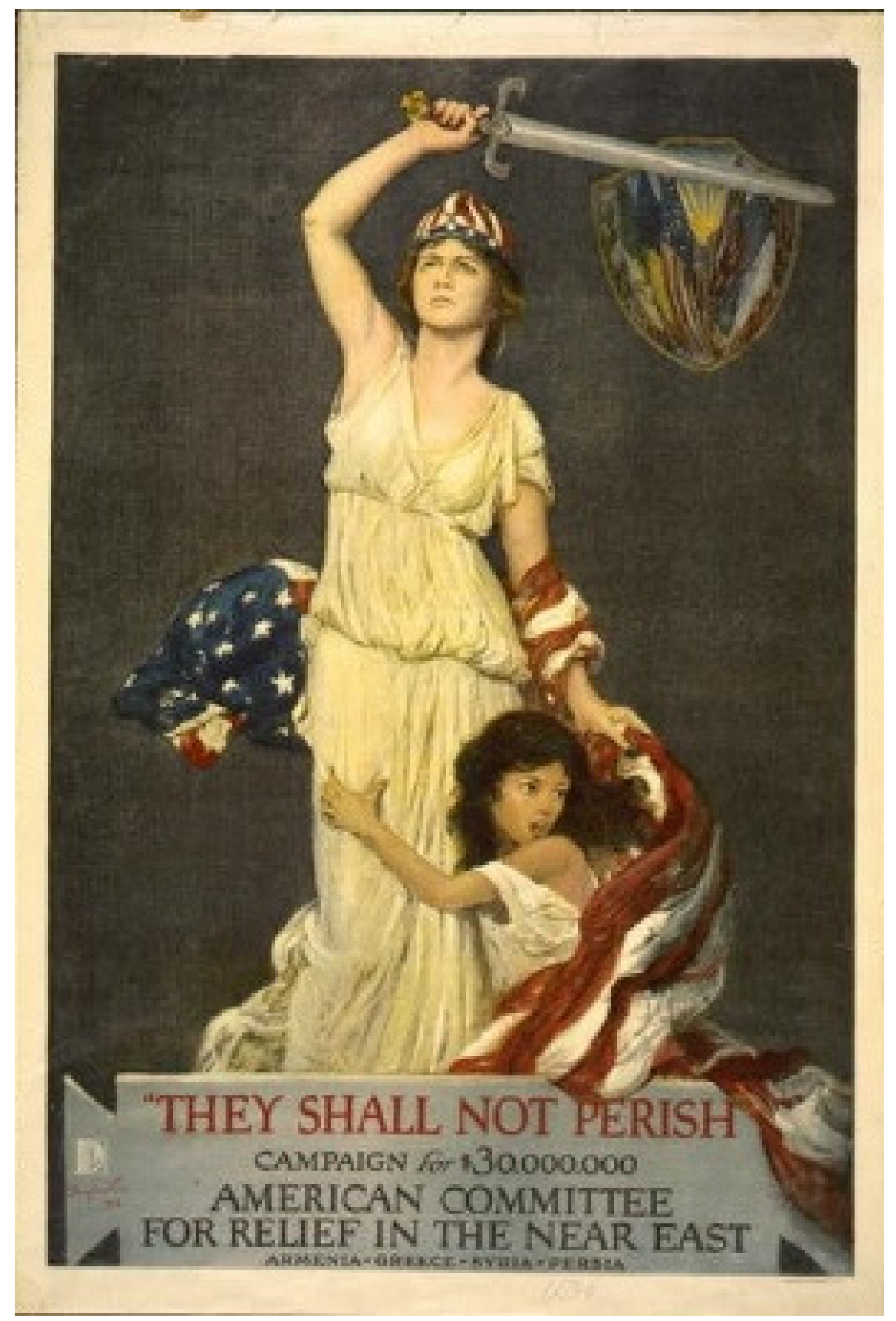


"Se você é neutro em

situações de injustiça, você escolhe o lado do opressor!

(Desmond Tutu) 


\section{AGRADECIMENTOS}

Aos meus filhos Maria Alice e Alexandre e à minha mãe Therezinha, pelas muitas horas de convivência que precisei trocar por leituras intermináveis.

À minha querida orientadora Maria Luiza, pela infinita paciência com minha falta de prática acadêmica, pelas valiosas sugestões e pelo cuidado e carinho demonstrado nas necessárias correções.

Aos professores Peter Demant e Lusiné Yeghiazaryan, pela inestimável contribuição para o direcionamento do estudo, durante a qualificação.

A Vassiliki Constantinidou, por me abrir os olhos, as portas e os horizontes e pela companhia constante nessa jornada.

Aos meus amigos gregos e armênios, pelo acolhimento e a abertura para que eu pudesse conhecer seu mundo e me sentir em casa, apesar de "estrangeira".

Aos funcionários da Escola Santa Tereza, pela compreensão nos momentos em que o meu trabalho precisou esperar.

E ao Pedro Ortiz, pai dos meus "três" filhos: Maria Alice, Alexandre e o livro dos gregos, que não virou realidade, mas me abriu as portas para um novo mundo e foi a fagulha inicial, sem a qual eu nunca teria iniciado este trabalho. 


\section{SUMÁRIO}

RESUMO

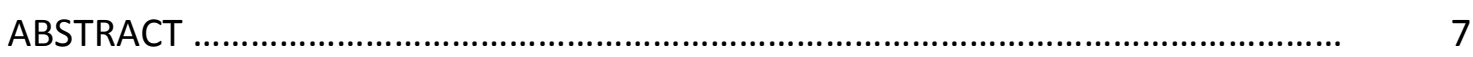

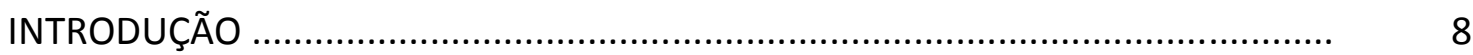

I - (CON)VIVÊNCIA E (IN)TOLERÂNCIA

1.1 - Grandes Impérios da Antiguidade: Roma e Pérsia............................... 22

1.2 - Divergências Religiosas.................................................................... 25

1.3 - Maomé e a difusão do Islã.................................................................. 28

1.4 - Ascensão e declínio Otomano............................................................ 31

1.5 - Interesses Imperialistas - As Grandes Potências Europeias................. 39

II - ANOS SELVAGENS: 1876 A 1923

2.1 - Abdul Hamid II - "Sultão Vermelho" ............................................... 46

2.1.1 - Primeiros massacres............................................................ 49

2.1.2 - Os "Jovens Turcos"................................................................ 57

2.2 - O Governo do CUP........................................................................ 60

2.2.1 - Práticas genocidas: política de limpeza étnica......................... 67

2.2.2 - A “Questão Armênia”.............................................................. 72

2.2.3 - Fim da Guerra, fim do CUP................................................. 87

2.3 - Mustafa Kemal e os nacionalistas...................................................... 93

2.3.1 - Os aliados divergem.......................................................... 99

2.3.2 - Guerra greco-turca.......................................................... 102

2.3.3 - "Gran Finale" - A República turca livre de cristãos.................. 114

III - ACORDOS E ACERTOS PÓS-GUERRA: A LUTA PELO RECONHECIMENTO

3.1 - Armênios e gregos frente ao negacionismo...................................... 121

3.2 - Turquia: negação dos fatos e controle da História............................. 134

3.3 - Consequências do negacionismo..................................................... 139

CONSIDERAÇÕES PRELIMINARES.......................................................... 145

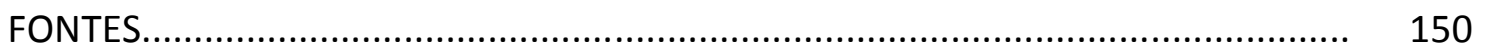

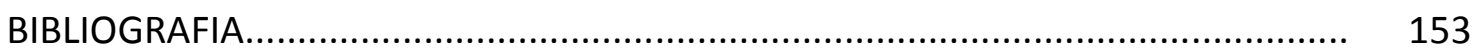




\section{ARMÊNIOS E GREGOS OTOMANOS - A Polêmica de um Genocídio}

\section{RESUMO}

O Genocídio Armênio (1914-1916), reconhecido por alguns estudiosos como o protótipo do genocídio moderno, é negado até hoje pelo governo turco, apesar dos protestos da comunidade armênia dispersa em todo o mundo. Oficialmente, a Turquia reconhece que ocorreram muitas mortes, mas nega a intenção estatal do ato genocida. Na mesma época ou até mesmo um pouco antes, os gregos - a outra grande minoria cristã do Império Otomano também sofreram massacres e perseguições, com um saldo de centenas de milhares de mortos, vivenciando situações semelhantes às sofridas pelos armênios.

Sob este mesmo viés, movimentos nacionalistas e imperialistas europeus levaram à perda significativa de territórios do Império Otomano, forçando, em consequência, a mobilização de centenas de milhares de muçulmanos que, fugindo do domínio cristão, instalaram-se na Anatólia, fortalecendo as questões etno-religiosas. Hoje, essas histórias seguem sendo motivo de questionamento, ainda que esquecidas ou silenciadas por alguns grupos.

O objetivo deste estudo é contribuir para a elucidação desta polêmica, reunindo um conjunto de informações que permita uma compreensão mais ampla do assunto. Com base na historiografia especializada no tema, procuramos inventariar e comparar as versões de diversos autores, cujos discursos são complementares ou mesmo antagônicos, bem como a posição oficial do governo turco, postada no site do Ministério das Relações Internacionais da Turquia. Somam-se aqui os testemunhos de sobreviventes e as declarações de diplomatas e missionários estrangeiros que presenciaram os acontecimentos.

\section{Palavras-chave: Genocídio, Armênios, Gregos, Ásia Menor, Negacionismo.}




\begin{abstract}
The Armenian Genocide (1914-1916), recognized by some scholars as the prototipe of the modern genocide, is denied by the turkish government even today, despite the protests of the armenian community around the world. Officially, Turkey recognizes that many people died in the period, but denies the genocidal intent. At the same time or little before. The greeks - the other major minority of the Ottoman Empire - also suffered with massacres and persecutions, resulting in hundreds of thousands dead, experiencing similar situations as those suffered by the Armenians.

In the same period, nationalist and imperialist movements led to great losses of territory of the Ottoman Empire, forcing, as a result, the mobilization of hundreds of thousands of muslims, escaping from the Christian rule, who settled at Anatólia, stressing the etno-religious conflicts. Today, those stories are still a reason to argue, even if forgotten or silenced by some groups.

The intention of this work is help on the elucidation of the polemica, collecting a set of informations that may allow a wider understanding of the subject. Using the specialized historiography, we tried to catalogue and compare the many opinions of authors, whose speeches are complementary or even opposing, as well as the official version of the Turkish government, posted at the Ministery of Foreign Affairs website. Here is added the voices of the survivors and the statements of foreign missionaries and diplomats, who witnessed the events.
\end{abstract}

Key-words: Genocide, Armenians, Greeks, Asia Minor, Denialism. 


\section{INTRODUÇÃO}

Entre os anos de 1894 e 1923, mais de dois milhões de cristãos perderam a vida no Império Otomano. Além disso, mais de dois milhões e meio de pessoas perderam tudo o que possuíam, inclusive suas raízes. Estes fatos raramente foram motivos de questionamentos. As causas, ações genocidas e consequências, no entanto, suscitam diferentes pronunciamentos, dependendo dos laços familiares ou políticos que identificam cada grupo ou pesquisador.

Os fatos e os testemunhos de sobreviventes e diplomatas estrangeiros comprovam que o genocídio ocorreu, sendo relatados, em essência, de forma semelhante: as datas e os locais coincidem, mas os números variam exageradamente e as razões apontadas são quase sempre antagônicas. O assunto é tratado por historiadores turcos, armênios, gregos, ingleses, americanos, entre outros, cujas obras são respeitadas. Cada livro apresenta um motivo diferente para os mesmos fatos. A pergunta mais óbvia diante destas diferentes versões nos parece ser: 'por quê?' Este é o objeto deste estudo: tentar identificar os argumentos que justificam tal controvérsia acerca dos fatos e, da parte turca, a negação absoluta ou um silêncio sepulcral.

Consideramos que após os acontecimentos que levaram à morte mais de um milhão de pessoas na Turquia no final do século XIX e início do século XX, houve uma grande dispersão dos sobreviventes pelo mundo. Da mesma forma como ocorreu com os judeus durante o nazismo (1933-1945), armênios e gregos ${ }^{1}$ - cristãos do Império Otomano espalharam-se por todos os continentes, buscando segurança e melhores condições de vida. A lembrança das perseguições assombraram essas pessoas ao longo de sua vida. Alguns esforçaram-se por narrar suas histórias, enquanto outros fecharam-se em um silêncio dolorido. Trauma e memória caminham juntos, principalmente nos casos evidentes de violência e intolerância sem limites.

Pouco mais de duas décadas mais tarde, o mundo foi abalado pelo horror ao tomar ciência dos episódios inenarráveis dos campos de concentração alemães. As imagens, as vozes dos sobreviventes e os cenários dos locais preparados para o extermínio continuam a

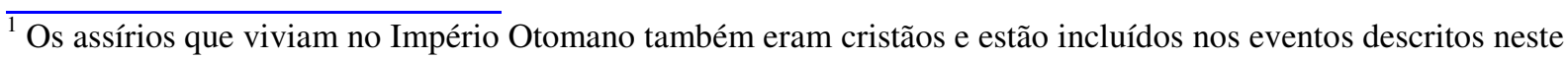
nosso estudo. Não figuram como objeto de pesquisa por conta do recorte que serve de balizamento a esta dissertação: armênios e gregos.
} 
causar impacto e indignação da humanidade. O Holocausto, reconhecido enquanto crime de genocídio, tem sido divulgado o máximo possível, para que nunca mais aconteça algo semelhante. Alguns de seus perpetradores e/ou mandantes foram julgados e condenados. A Alemanha ainda está aprendendo a lidar com este seu passado e, aos poucos, o povo alemão procura tirar dele suas lições de vida para um mundo mais justo. Mesmo assim, os movimentos neonazistas e as posturas negacionistas contra o Holocausto continuam a ocupar espaço junto às mídias, demonstrando que o homem ainda não aprendeu a lição.

Entretanto, analisando as versões que persistem sobre a história do "genocídio armênio",2 hoje, identificamos inúmeras semelhanças, principalmente filosóficas, entre as duas tragédias. Talvez, os judeus pudessem ter sido poupados, se os atos cometidos na Turquia tivessem sido devidamente punidos. Se os mandantes, no caso turco, tivessem encontrado seus algozes, o exemplo armênio despontaria como um alerta contra a intolerância e a violência institucionalizadas, ainda que camufladas. Ao invés disso, o próprio Hitler justificou seus planos genocidas com a frase: “afinal, quem se lembra dos armênios?", pronunciada durante um discurso aos soldados alemães pouco antes da invasão da Polônia. A pergunta tornou-se referência não só pelo obvio sentido da impunidade absoluta, mas também pelo exemplo. Se as vozes armênias tivessem sensibilizado o mundo em tempo, talvez o horror nacional-socialista não tivesse alcançado tais dimensões.

Hoje, a comunidade armênia espalhada pelo mundo procura resgatar cada indício de seu martírio, valendo-se de qualquer prova que ratifique sua história. Precisam desses argumentos para enfrentar a negação absoluta do governo turco e seguir na esperança por justiça. Neste contexto abalado pelo negacionismo que persiste nos dias de hoje, consideramos importante retomarmos alguns aspectos históricos. Até mesmo para compreendermos melhor os argumentos apresentados por aqueles segmentos que reivindicam o reconhecimento do "genocídio armênio" como protótipo do genocídio moderno. ${ }^{3}$ Por outro lado, para preservar o nome dos heróis nacionais, o governo turco esforça-se na busca de contra-argumentos que refutem as acusações armênias em busca de reconhecimento dos fatos enquanto genocídio. Apesar de alguns parecerem forjados, ainda são utilizados como discurso oficial do Estado Turco, gerando o resultado desejado: a dúvida.

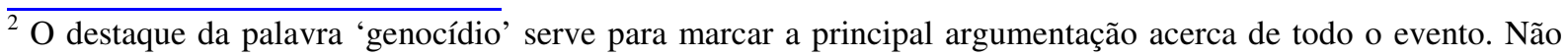
expressa a nossa opinião pessoal. Empregamos a definição de genocídio armênio, pois é assim que a maioria dos autores o nomeia. Os gregos serão citados ao longo do texto.

3 Em 2009, o LEER - Laboratório de Estudos sobre Etnicidade, Racismo e Discriminação - organizou o seminário "95 anos do Genocídio Armênio", junto a Universidade de São Paulo. Deste evento participaram importantes estudiosos do Instituto Zoryan, da Canadá, tendo esta posição como tema de suas investigações.
} 
Os armênios, povo estabelecido nos planaltos da Anatólia há mais de mil anos, viviam nas grandes cidades, como comerciantes, ou em vilas rurais, praticando a agricultura e pecuária, com uma organização social bastante avançada, com boas escolas, hospitais. Muitos eram artesãos ou tinham profissões liberais. Eram cristãos e, como tal, não tinham o direito, por exemplo, de portar armas. Nas regiões rurais, na Anatólia oriental, seus vizinhos mais próximos eram os Curdos e os Circassianos, tribos nômades e violentas, bastante imprevisíveis. Os armênios viviam em constante sobressalto pois, a todo momento, sofriam ataques curdos aos quais tinham dificuldade de resistir. Para manterem suas posses, pagavam aos curdos uma "taxa", além dos impostos devidos ao governo otomano. Durante décadas reclamaram uma solução da Porta ${ }^{4}$, sem sucesso.

Em Constantinopla a situação era outra: no final do século XIX, ali viviam cerca de 250 mil armênios, muitos com posições de prestígio junto ao governo, embora a lei islâmica não permitisse que os infiéis se dedicassem à política. Alguns eram senhores de grandes fortunas advindas dos negócios, pois somente os 'infiéis' se dedicavam ao comércio e ao mercado financeiro. Os armênios 'urbanos', mais cultos, acreditavam que a solução para seus problemas estava na via política. A crescente tomada de consciência de seus direitos civis culminou com a adoção de uma Constituição Nacional Armênia, utilizada dentro do seu respectivo millet. ${ }^{5}$ Enfim, esperavam da Sublime Porta a autonomia que os reconhecesse enquanto cidadãos com direitos.

O Sultão Abdul Hamid ${ }^{6}$ II (1876-1908) encontrou algumas soluções para estas demandas: armou os Curdos e Circassianos ainda mais, chegando mesmo a formar uma tropa, (chamada de `Hamidieh ou de Hamid) com a intenção nominal de controlar as fronteiras com a Rússia. Mas, na prática, este grupo estava incumbido de 'controlar' os armênios. Entre 1894 e 1896, Hamid logrou "liquidar" cerca de 200.000 armênios. A maneira clássica de iniciar as querelas que sempre resultavam em massacres - com mortos dos dois lados, mas muitas mais do lado armênio - era provocar o povo, exigir mais impostos ou confiscar bens, com a intenção de fazer com que algum armênio perdesse a cabeça:

"Os sacerdotes e líderes políticos armênios viram muitas evidências de que os turcos estavam [provocando rebelião] e falaram às pessoas avisando para ficar quietos e aguentar os insultos e até ataques com paciência, para não dar motivos para provocação. 'Mesmo que eles queimem algumas de nossas aldeias', teriam dito esses líderes, 'não

\footnotetext{
${ }^{4}$ Sublime Porta, o centro administrativo do Império - o próprio Sultão e seus ministros.

${ }^{5}$ SAPSESIAN, Aharon. História Sucinta e Atualizada da Armênia. São Paulo, Emblema. 2010, p. 101.

${ }^{6}$ Os nomes das personagens variam de acordo com o autor ou o idioma da obra. Pode-se encontrar também escrito como Abdulhamid, Abdul Hamit ou Abdulhamit.
} 
procurem retaliação porque é melhor que alguns sejam destruídos do que uma nação inteira ser massacrada."

Durante o reinado de Abdul Hamid II, as mortes de armênios aconteciam durante ataques a vilas no interior da Anatólia, onde sempre havia um argumento acionado pelo governo turco para que suas tropas fossem 'restabelecer a ordem'. De fato, alguns armênios estavam mobilizados e organizavam atos terroristas, como o sequestro no Banco Otomano, atos que instigavam a retaliação turca à população armênia.

Em 1908, o movimento dos Jovens Turcos, tomou o poder e depôs o sultão, colocando em seu lugar um irmão menos dominador, Mehmet. Em sua plataforma política figurava a intenção de modernização do Império e igualdade entre as muitas etnias sob seu comando. A subida de Mehmet ao poder levantou ondas de jubilo e muitas festas nas ruas, com armênios, gregos e turcos se abraçando e comemorando juntos. ${ }^{8}$ Apesar de tal intenção declarada, o Comitê para União e Progresso (CUP) mostrou-se pouco inclinado para solucionar o problema dos cristãos, muito pelo contrário. Em pouco tempo, principalmente após as derrotas turcas nas guerras balcânicas (1912-13), com uma considerável perda de território, transpareceu a tendência nacionalista dos integrantes do CUP. O lema "Turquia para os turcos" mostrou a direção para onde soprariam os ventos no Império.

A independência da Grécia balcânica, cujo território foi praticamente duplicado após a segunda guerra balcânica em 1912, fez a balança pender negativamente para os gregos da Ásia Menor, ainda súditos do sultão otomano. Entre 1912 e 1913, houve uma tentativa de "enfraquecer" a comunidade grega, com boicotes ordenados pelo governo. As lojas de gregos não deveriam ser frequentadas por turcos e os turcos que tivessem empregados gregos deveriam demiti-los e substituí-los por trabalhadores turcos.

Centenas de gregos foram mortos ao tentarem proteger suas posses em meio às tentativas de deportação, nas cidades da costa do mediterrâneo. O governo obrigou a formação de batalhões de trabalho, em que os homens entre 15 e 50 anos eram convocados para trabalhar na construção de estradas, restauro de ferrovias, etc.. Estes homens eram mantidos em regime de escravidão, recebendo uma ração insuficiente de alimento e trabalhando em condições extremas, sob a neve no Cáucaso ou em meio ao deserto. A maior parte deles pereceu. Muitos gregos das cidades costeiras foram transportados à revelia, para as ilhas do Mar Egeu em 1913. Estas ações, entretanto - fortemente criticadas pelos diplomatas

\footnotetext{
${ }_{7}^{7}$ MORGENTHAU, Henry. Ambassador Morgenthau's Story. New York, Doubleday, Page \& Co., 1918, p. 296.

${ }^{8}$ HORTON, George. The Blight of Asia, London, Sterndale Classics, 2nd Ed., 2008, p. 16.
} 
estrangeiros - acabaram causando protestos das grandes potências europeias. Com isso, o CUP ordenou que toda a operação cessasse imediatamente e organizou comissões para apurar os fatos e punir os responsáveis.

Com o início da Primeira Guerra Mundial em 1914, no entanto, os disfarces deixaram de ser necessários favorecendo a política de deportações implementada de forma rápida e eficaz. A derrota contra a Rússia em Sarikamiş, na qual participaram ativistas armênios auxiliando os russos, foi suficiente para que os armênios fossem considerados 'não confiáveis'. Para afastá-los dos soldados que lutavam no front de batalha, foi criada a Lei de Deportação (Tehcir) em 27 de Maio de 1915. Com isso, moradores de aldeias inteiras foram retirados de suas casas: primeiro os homens em idade de combate (de 15 a 70 anos), foram levados em fila por alguma estrada, com o pretexto de transferi-los para uma área mais tranquila do país. Porém, ao cabo de alguns quilômetros ou até mesmo na primeira curva da estrada, os soldados pilhavam e massacravam a todos, com a ajuda dos curdos ou de bandidos convenientemente liberados das cadeias na noite anterior. Uma vez aniquilados os homens, sem a mínima possibilidade de resistência, passavam a retirar as mulheres, crianças e velhos, fazendo-os caminhar rumo ao nada até que a fome, o frio, a exaustão ou os maus tratos os levassem à morte. Esta ação tão bem orquestrada ocorreu ao mesmo tempo em quase todo o país, exceto nas cidades maiores, como Constantinopla e Esmirna, onde haviam observadores estrangeiros.

\begin{abstract}
"A destruição de vidas têm sido sem exemplo em toda a região, desde as fronteiras da Pérsia até o Mar de Mármara, tendo por ora escapado apenas algumas poucas cidades na costa do mar Egeu. Dá-se isto porque as operações foram planejadas com tanto cuidado e executadas sistematicamente com tão desapiedada eficiência, como até aqui nunca se vira entre os turcos. (...) Tudo foi feito pela vontade do governo (...) porque desejavam, por razões puramente políticas, desfazer-se de um elemento não muçulmano que contrariava a homogeneidade do império..."
\end{abstract}

Embora o alvo principal nesse momento fossem os armênios, partilhavam do mesmo tratamento gregos, búlgaros, sérvios e outros tantos grupos que professassem a religião cristã. Os mesmos autores que relatam a história armênia referem-se aos cristãos em muitos momentos ${ }^{10}$. A política de deportação em massa não era novidade na época, nem tampouco exclusividade turca. Os russos a utilizavam em suas organizações no Cáucaso, e também os

\footnotetext{
${ }^{9}$ Discurso proferido por Lorde Bryce na Câmara dos Lordes em 6 de outubro 1915, apud TOYNBEE, Arnold, Bryce, James, Atrocidades Turcas na Armênia. São Paulo, Paz e Terra, 2003, p. 17.

${ }^{10}$ Hoje podemos perceber que o que começou como uma questão de diferenças religiosas evoluiu para uma questão nacionalista. Durante o século que se seguiu às perseguições de que tratamos, houveram muitas perseguições a grupos muçulmanos, como os curdos, que ainda sofrem o peso de ser minoria entre turcos.
} 
alemães lançavam mão desta solução quando desejavam remover um grupo indesejável do seu caminho ou povoar determinada região com 'população confiável'.

Os gregos sofreram sua parcela de deportações em 1894, na costa do Mar Negro e também pereceram aos milhares nas marchas forçadas através das montanhas, para chegar a nenhum lugar e, se chegassem, somente para serem informados que podiam retornar as suas casas. Esse mesmo subterfúgio foi utilizado várias outras vezes, sempre que necessário. O que difere o caso dos gregos do armênio, ao nosso ver, além de os armênios terem sofrido massacres durante as marchas, é o fato de haver uma comunidade armênia forte na diáspora, que tomou o caso como ponto de honra, não permitindo que seja esquecido. Outra diferença, mais significativa, são os documentos identificados por especialistas, comprobatórios da intenção dos líderes do governo otomano quanto ao extermínio do povo armênio.

Os telegramas de Talaat Pasha, Ministro do Interior do governo otomano, aos governadores de província com ordens expressas para deportar e eliminar os armênios são provas que a comunidade armênia se orgulha de possuir e que o governo turco afirma serem invenções. Mas acerca dos testemunhos de diplomatas presentes na Turquia no momento dos acontecimentos, como o Embaixador Americano Henry Morgenthau, o governo turco não se pronuncia. Fica evidente que os documentos enviados por diplomatas em missão no Império Otomano aos seus países, no ato da tragédia, contém informações importantes que podem ajudar a discernir a questão. Tais registros ratificam a intervenção genocida, principalmente por parte dos líderes do governo.

"Talaat explicou sua política nacional: esses blocos diferentes no Império Turco, ele disse, sempre conspiraram contra a Turquia; devido à hostilidade dessas populações nativas, a Turquia havia perdido província após província - Grécia, Sérvia, Romênia, Bulgária, Bósnia, Herzegovina, Egito e Trípoli. Desse modo, o Império Turco havia diminuído quase a ponto de sumir. Se o que restou da Turquia devia sobreviver, disse Talaat, ele devia se livrar desses povos". ${ }^{11}$

No caso da Armênia, pode-se encontrar razões tanto políticas quanto econômicas. Do ponto de vista político, o território ocupado pelos armênios situava-se no centro da atual Turquia e uma possível independência teria sido um desastre para as ambições otomanas. Economicamente, os armênios detinham grandes fortunas enquanto os turcos estavam cada vez mais empobrecidos, gerando disputas, tensões e ódio entre os dois grupos.

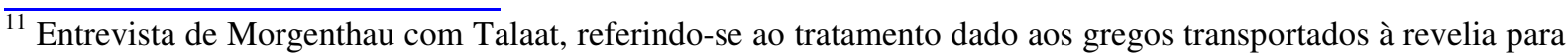
as ilhas do Mar Egeu, em 1913, na qual faz referência aos cristãos do império, apud MORGENTHAU, op. cit., p. 51.
} 
O problema com os gregos, por sua vez, tem raízes mais obscuras. O espaço ocupado pelo Império Otomano havia sido outrora o poderoso Império Bizantino, persistindo a disputa de território entre gregos e turcos. Apesar de terem sido totalmente dominados pelo Sultão Otomano Mehmet II (O Conquistador) em 1453, algumas famílias gregas, conhecidas como Phanariotes $^{12}$, mantiveram certo prestígio dentro do Império e, com o tempo, se tornaram realmente poderosas. No final do século XIX, a maior parte dos bancos do Império Otomano eram propriedade de gregos, além de ser grega a maior frota mercante do mundo.

Parte do sucesso dos gregos devia-se, como no caso dos armênios, ao fato de serem Dhimmis. Dhimmis, ou povos da al-Dhimma (do Pacto), eram cidadãos otomanos, porém de segunda classe. Tinham alguns direitos importantes para sua vida cotidiana e a convivência pacífica com os muçulmanos, mas somente enquanto aceitassem a condição de inferiores. Estavam, por exemplo, impedidos de portar armas e entrar para o exército, o que permitia que tocassem seus negócios sem interrupção. E como acontecia com os armênios, a fortuna dos gregos causava também um certo para mal estar junto à população turca, menos favorecida. Importante considerarmos os questionamentos do governo, que procurava fazer com que o poder econômico 'retornasse' às mãos dos turcos, quando nunca havia estado ali.

Quando a Revolução Grega (1921-29), após anos de sangrentas batalhas, logrou concretizar a independência e o Estado Grego foi criado, com forte apoio das potências europeias, a população grega subordinada ao sultão passou a ser vista com desconfiança. Este sentimento tinha sua razão de ser, pois para manter a unidade do recém-criado (e ainda não muito firme) Estado Grego, em 1844 Ioannis Kolletis, Primeiro Ministro grego, lançou a Megali Idea (Grande Ideia): o grande sonho de estender o território grego a todas as regiões em que houvesse gregos sob o jugo otomano. Considerando que o status de "povo grego" poderia ser aplicado a boa parte dos habitantes do Império Bizantino de quatro séculos atrás, seria quase como dizer que o território grego deveria ser o próprio Império Otomano ${ }^{13}$.

As Guerras Balcânicas ratificaram as intenções expansionistas gregas levando desespero aos Jovens Turcos, então no governo. Algumas medidas precisavam ser tomadas para impedir o completo esfacelamento do Império Otomano, como desejavam todas as potências, por diferentes motivos.

\footnotetext{
$\overline{12}$ Phanariotes eram os gregos que habitavam o opulento bairro de Phanar, em Constantinopla, quando da conquista da cidade pelos otomanos em 1453. Estes gregos foram poupados pelo Sultão naquele momento, por serem, de alguma forma, úteis ao governo e seguiram servindo à administração do palácio e mais tarde, do Império.

${ }^{13}$ CLOGG, Richard, A Concise History of Greece. $2^{\text {nd }}$ Ed. Cambridge, Cambridge University Press, 2002 , p. 91.
} 
Revisando essa história, parece natural que os massacres, que de fato ocorreram, fizessem parte de uma reação do governo otomano diante da perspectiva de perder o patrimônio que seus ancestrais conquistaram. E realmente, em alguns casos, o governo turco admite a luta por manter o Império "a qualquer custo". Entretanto, a pressão da comunidade armênia exige o reconhecimento desses massacres enquanto Genocídio, crime descrito pelo direito internacional, passível de punição, imprescritível. Essa prerrogativa é abominada pelo governo turco, que apesar das pressões internacionais, procura sustentar a sua versão dos fatos através do negacionismo. O comentado artigo 301 do Código Penal Turco prevê pena de prisão para quem "denegrir a 'turquicidade"”. Entre outros atos, a associação das mortes armênias com a palavra "genocídio" enquadra-se nesse artigo e já foi motivo para punição para vários intelectuais turcos, como Orhan Pamuk, Taner Akçam, Ragip Zarakolu.

O assunto é controverso desde a própria definição para o crime de genocídio, como será discutido adiante. Cada linha de pensamento procura incluir ou excluir um determinado grupo daqueles que podem ser enquadrados como vítimas de genocídio ou daqueles que podem ser os perpetradores. Neste estudo, não pretendemos aprofundar ainda mais essa discussão e sim apresentar um conjunto de argumentações e definir uma delas como nossa linha mestra para discutirmos o papel dos atores que serão apresentados.

Os governantes turcos atuais têm muito pouco em comum com aqueles que idealizaram as "deportações", porém os perpetradores das atrocidades contra os cristãos também foram os idealizadores da nova Turquia e, portanto, sua memória é intocável. Ainda que três dos principais membros do governo na época tenham sido julgados e condenados por esses crimes após o final da Primeira Guerra Mundial, eles estavam fora da Turquia por ocasião da sentença e nunca sofreram sequer uma sanção. Seguiriam suas vidas na Alemanha ou na Rússia, sem atropelos, se não fossem as ações de alguns armênios inconformados ${ }^{14}$.

A voz de Talaat Pasha, Ministro do Interior de 1913 a 1917, ecoa como aquele que decidia quando e para onde deportar. Somente com seu assassinato em 1921 em Berlim, por um sobrevivente das marchas da morte é que veio à luz parte da tragédia armênia. $\mathrm{O}$ julgamento de seu assassino, réu confesso, trouxe uma grande surpresa: o júri absolveu Salomon Teilirian, em vista do imenso sofrimento infringido ao povo armênio por sua vítima. Essa decisão abriu um precedente para a discussão sobre as atrocidades contra os armênios. A partir da repercussão desse julgamento, as notícias começaram ter visibilidade em inúmeras instâncias, sendo valorizadas sob o ponto de vista das vítimas.

\footnotetext{
${ }^{14}$ Os três líderes do CUP morreram no espaço de poucos anos, Talaat e Djemal assassinados por armênios e Enver durante uma investida contra os soviéticos.
} 
Antes desse momento, já circulavam rumores sobre o que acontecia dentro do vasto Império Otomano, registradas pelos maiores jornais da época: New York Times, Chicago Tribune, The Herald. Entretanto apesar destes periódicos terem estampado em manchetes as mortes de tantas pessoas na Turquia, seus correspondentes escreviam aquilo que lhes era permitido escrever. As notícias dependiam muito da distância em que se encontravam as tropas inimigas naquele momento e das relações políticas dos países envolvidos com a divulgação da notícia.

É necessário considerar também a forte influência dos imperialismos europeus sobre os acontecimentos que pretendemos analisar. O jogo de poder entre as grandes potências da época, Inglaterra, França e Rússia, muitas vezes causava repercussões nos demais países, principalmente neste caso. Por exemplo, após o armistício que colocou fim à Primeira Guerra, em 1918, os Aliados, apesar de saberem que isso seria desastroso para a população grega e armênia, decidiram pelo desembarque de tropas gregas, que ficariam responsáveis pela administração da cidade de Esmirna, a segunda maior cidade do Império, cuja população era de maioria cristã. Assim que essas tropas desembarcaram, o forte sentimento anticristão voltou a aflorar e teve início uma nova guerra, chamada por alguns (gregos) de Guerra GrecoTurca e por outros (turcos) de Revolução Nacionalista.

A vitória turca contra os gregos em setembro de 1922 recuperou o pesadelo para os cristãos de todo o país. A cidade de Esmirna, com mais de um milhão e meio de habitantes, foi quase totalmente destruída por um incêndio que começou pouco depois da entrada das tropas turcas e do massacre de armênios e gregos que ocorreu em seguida. Milhares pereceram como vítimas das ações violentas de soldados, mas também de populares turcos. Outros milhares passaram semanas no cais, aguardando um resgate pelos navios aliados ancorados no porto, um resgate que não ocorria porque nenhum dos governos dos aliados desejava desentender-se com Mustafa Kemal, o novo líder nacionalista. Mesmo após a autorização para que fossem retirados da cidade, somente as mulheres, crianças e velhos foram transportados para a segurança. Os homens, mais uma vez, foram levados para o interior em batalhões de trabalho, sem qualquer condição de sobrevivência. Milhares de gregos deixaram a Turquia nesse momento, levando consigo apenas a esperança de justiça.

No início de 1923, o governo provisório de Kemal assinou o Tratado de Lausanne, selando como definitiva a paz com os Aliados. Em troca, a Turquia recuperou suas fronteiras e ainda, agora com autorização oficial, expulsou de seus domínios todos os cristãos e recebeu os muçulmanos que viviam na Grécia. A operação de troca de populações foi realizada em tempo recorde, mas pouco importava aos governos turco e grego o sofrimento da população 
esfomeada e sem abrigo no local de destino. Milhares de pessoas morreram de tifo durante o transporte, sem que fosse permitida qualquer medida para sanar o problema.

Por fim, em 29 de Outubro de 1923, a República turca foi inaugurada com pompa e circunstância, por sobre um mar de sangue. Durante os anos que se seguiram, Kemal empreendeu diversas reformas no país, procurando recuperar a economia do país e aproximar a Turquia dos padrões ocidentais. Uma das medidas mais importantes foi a reforma do alfabeto. Além disso, Kemal fundou a Turkish History Research Society ${ }^{15}$, uma sociedade de historiadores responsáveis por escrever a história do país para a posteridade.

Ao revisar a obra de pesquisadores que, nas décadas de 1950-60, tiveram acesso aos arquivos otomanos, em vários casos -citados e discutidos neste estudo - nota-se a preocupação em eximir o governo turco da responsabilidade por essas mortes. É o caso, por exemplo, de Stanford Shaw, que considera:

"Em pouco tempo, apesar de todos os esforços do governo para manter a ordem, os Hunchaks ${ }^{16}$ tiveram o que queriam, represálias dos moradores muçulmanos das vilas"17

De acordo com outras obras, produzidas por Donald Bloxham e Taner Akçam, por exemplo, nem o governo pretendia apenas manter a ordem e nem foram somente os moradores das vilas que empreenderam represálias aos atos terroristas dos ativistas armênios. Ao contrário: em muitos episódios, quando as milícias muçulmanas não conseguiram a vitória sobre os armênios, o Sultão enviou suas tropas para 'restabelecer a ordem'. Curiosamente, a ordem era "restabelecida" com violência seguida de um número muito maior de armênios mortos, se comparados aos turcos ou curdos, embora em quase todos esses locais, os armênios fossem minoria populacional. Nota-se, por exemplo, a preocupação de Shaw, em deixar claro que a postura do governo era imparcial. ${ }^{18}$ Importante verificar que os questionamentos da comunidade armênia acerca dos episódios em questão incentivaram novas investigações com argumentos descobertos ao longo do tempo. Pelo lado turco, no entanto, os documentos históricos supostamente guardados nos arquivos otomanos desde a época, utilizados como prova para refutar as acusações armênias, parecem já conter as respostas a cada uma das questões levantadas, o que pode nos levar a considerar a possibilidade de fraude.

\footnotetext{
${ }^{15}$ The Turkish History Research Society, segundo o professor Farrokh, um instrumento para reescrita conveniente da história otomana. Ver FARROCH, Kaveh, Pan-Turanism Takes Aim at Azerbaijan: A Geopolitical Agenda. Fonte de internet: http://www.rozanehmagazine.com/NoveDec05/aazariindex.html ${ }^{16}$ Hentchaguian é o nome de um dos partidos políticos armênios, fundado na Suíça em 1887. "Os hunchaks" é a forma como alguns autores referem-se a grupos de militantes que buscavam a atenção principalmente das potencias europeias por meio de ações provocativas ou mesmo terroristas.

${ }^{17}$ SHAW, Stanford, History of the Ottoman Empire and Modern Turkey 1808 - 1975 v. II. New York, Cambridge University Press, 1977, p. 203.

${ }^{18}$ Idem.
} 
Importante lembrar que quando a República da Turquia foi proclamada por Mustafá Kemal, em 1923, houve uma grande preocupação com a história deste país. Foi promovida, entre outras, a reforma do alfabeto turco, que antes utilizava caracteres árabes e passou a usar o latino, a fim de facilitar a aproximação com o Ocidente. Com este ato, de acordo com Andrew Mango, seu biógrafo, Kemal facilitou o aprendizado da língua para as novas gerações $^{19}$. Com este ato também, na opinião de Taner Akçam, historiador turco, Kemal praticamente fechou o acesso das novas gerações aos arquivos otomanos.

"A Turquia é uma nação que não pode ler seus próprios jornais ou diários, se eles tiverem sido escritos antes de 1928. Não tem acesso a nada que aconteceu antes dessa data. Como resultado, a Turquia moderna é totalmente dependente da história que o Estado define e escreve." 20

As opiniões divergem, mas o fato é que as duas coisas realmente ocorreram. Pode ser que a intenção de Kemal fosse apenas levar o país ao progresso, mas sendo quem era, um excelente estrategista, é muito difícil crer que não tivesse percebido a consequência que seu ato teria. É claro que existe um exagero de Akçam ao dizer que a Turquia não pode ler seus jornais antigos, muitas pessoas provavelmente estudaram e podem ler os caracteres árabes, mas certamente, essa medida dificultou sobremaneira o acesso ao passado registrado em documentos.

Pesquisar, contestar ou denunciar as versões históricas sustentadas pela Turquia não é tarefa fácil para um estudioso e/ou ativista dedicado a esclarecer esta polêmica. Taner Akçam - turco, nascido em Ardahan, por exemplo, esteve preso por nove anos na Turquia, por editar um periódico estudantil. Atualmente, vive em Minesota, EUA, com asilo político. Muitos outros pesquisadores tiveram a mesma sorte. Nos dias de hoje, discutir a capacidade de Kemal Atatürk enquanto líder político é crime punível com prisão na Turquia, assim como referir-se às mortes dos armênios utilizando a palavra 'genocídio' .

Intelectuais turcos continuam a ser perseguidos e mesmo presos por investigarem esses temas tabus ${ }^{21}$, mas a versão oficial nega também esse fato. Assim, entre o silêncio e o negacionismo, o povo turco tem pouca oportunidade de conhecer seu passado e, ainda menos, de tirar do anonimato os nomes das vítimas de um estado de exceção. Em mais alguns anos, o projeto de Kemal terá alcançado suas aspirações: o esquecimento completo dos atos de intolerância máxima, restando apenas as condecorações aos heróis nacionais.

19 MANGO, Andrew, Atatürk - the Biography of the Founder of Modern Turkey, New York, The Overlook Press, 2002, p. 465.

20 AKÇAM, Taner. A Shameful Act. Translated by Paul Bessmer. New York, Metropolitan Books, 2006, p. 11.

${ }^{21}$ FERRO, Marc. Os Tabus da História- A Face Oculta dos Acontecimentos que Mudaram oMundo. Rio de Janeiro, Ediouro, 2002, p. 38. 
Não temos aqui a pretensão de discutir se as razões de um e outro lado foram ou não válidas, ou fazer um juízo de valores sobre a vida e a obra dos envolvidos. Fica evidente que o governo otomano precisava manter o controle sobre seus súditos, assim como o fato de haverem protestos por parte da população muçulmana que pressionava os governantes, quando o império havia perdido, em poucos anos, mais de 5 milhões de súditos pagantes de impostos e mais de $400.000 \mathrm{~km} 2$ de território de terras agriculturáveis. É compreensível que o povo muçulmano, o agricultor em estado de miséria ou o soldado sem condições profissionais e mal armado, se ressentisse das grandes fortunas conquistadas por armênios e gregos ${ }^{22}$. Os infiéis estavam desde sempre excluídos das forças armadas e, com isso, apesar de pagarem altas taxas de impostos, não precisavam deixar seus negócios nos tempos de guerra. Ficavam livres para exercer profissões liberais e dedicar-se ao comércio, inclusive em grande escala ${ }^{23}$. Como o Islã não permitia o empréstimo de dinheiro a juros, essa função ficou totalmente nas mãos dos Gâvur (infiéis), muitos dos quais se tornaram grandes banqueiros. É natural que esse fato despertasse ódios, principalmente quando o povo tinha dificuldade para alimentar as suas famílias. Não é de se admirar que as casas dos armênios deportados tenham sido quase imediatamente invadidas e apropriadas pelos vizinhos muçulmanos, ainda que esta não fosse a orientação estatal, situação que dificilmente poderá ser provada. Eram casas melhores, mais confortáveis, em melhor localização e estavam vazias.

No decorrer da apresentação dos fatos históricos, procuramos realizar uma discussão o mais imparcial possível, levantando um conjunto de situações em que os muçulmanos, ao menos inicialmente, tinham razão. É preciso também levar em conta que o nível cultural da população do Império naquele momento era muito baixo, assim como o índice de escolaridade, situação que restringia a capacidade de compreensão dos problemas multifatoriais que os afligiam. A maior parte da população, provavelmente, entendia essas questões da forma como lhes eram explicadas através da rede oficial de comunicações. A propaganda direcionada para o ódio nos ajuda a compreender a grande quantidade de episódios marcados por linchamentos e massacres levados a termo pela população local.

Tais considerações nos parecem necessárias para uma análise de fato isenta de julgamentos, ainda que esta seja uma tarefa difícil. É possível imaginar a angústia dos

\footnotetext{
$\overline{22}$ É interessante notar que os judeus também possuíam grandes fortunas, mas não encontramos relatos do mesmo tipo de 'boicote' aos judeus no Império Otomano. Ao contrário, quando a população foi proibida de comprar em lojas gregas e armênias, nos vários boicotes realizados, as lojas dos judeus foram muito procuradas.

${ }^{23}$ É nesse momento que começa a se construir a frota mercante grega, que se tornou a maior do mundo no século XX.
} 
muçulmanos forçados a deixar a Rumélia ${ }^{24}$ após as guerras balcânicas. Entende-se, enfim, que as pressões políticas, religiosas e financeiras daquele momento histórico eram imensas, gerando múltiplas situações de conflito.

O que nos causa estranheza e que acabou por suscitar a escolha deste tema como objeto de pesquisa, é o fato de o governo turco afirmar e reafirmar essas e várias outras razões e não reconhecer fatos que são incontestáveis. Como exemplos, citamos algumas respostas às "perguntas frequentes" no site do Ministério do Interior turco, fonte oficial de informação do governo $^{25}$ :

Nessa lei ${ }^{26}$, todas as medidas foram pensadas para assegurar a segurança dos armênios sujeitos a relocação. (...) Apesar dessas medidas, as condições de Guerra, gangues locais, roubos, ódios e sentimentos de vingança dos vizinhos suscitaram ataques aos comboios durante o processo de transferência. O governo tentou evitá-los. ${ }^{27}$.

Uma resposta assim seria convincente, se não houvessem testemunhos de sobreviventes armênios, de turcos e curdos que ajudaram alguns deportados, ocultando-os para salvar suas vidas, embora sob ameaça de prisão. Se não houvessem testemunhos de diplomatas e missionários que se referem ao estado calamitoso em que se encontravam as pessoas nos campos de reunião ao longo da marcha e ao fato de serem proibidos de levar comida a essas pessoas. Seria compreensível, se não houvessem sido recrutados presidiários muçulmanos, para 'proteger' os deportados, a quem era oferecida a liberdade e os bens das famílias que conseguissem expulsar. Devemos também considerar que os locais que "abrigariam" os deportados eram regiões absolutamente estéreis, desérticas ou pantanosas, onde jamais poderiam estabelecer uma nova vida.

Em síntese, o que nos chama a atenção é a negação quase pueril de situações históricas indiscutíveis e amplamente testemunhadas que ainda hoje persistem nas versões oficiais produzidas pelo governo da Turquia e seus intelectuais orgânicos. Mesmo após a morte dos envolvidos, após um século de reformas, de diálogos diplomáticos promissores e

\footnotetext{
${ }^{24}$ Território otomano que abrangia a península balcânica e as províncias ao norte, hoje Bulgária, Romênia, Montenegro, Servia, Croácia, Grécia, Albânia.

${ }^{25}$ Numa tentativa de entrevista ao cônsul turco em São Paulo, ouvimos a seguinte resposta da funcionária que atendeu o telefonema: 'tudo o que nós podemos lhe dizer está no site oficial do governo turco'. São Paulo, Março de 2012.

${ }^{26}$ Refere-se à Lei de Deportação, criada em 1915 pouco antes das deportações começarem, com a intenção declarada de proteger as populações próximas ao front de batalha.

${ }^{27}$ Site oficial do Ministério de Relações Exteriores da Turquia: www.mfa.gov.tr/faq
} 
tentativas de explicas os antigos desafetos, o governo turco não altera sua posição: não reconhece nem ao menos o 'erro de cálculo' ou a 'falha logística' de seus antepassados.

É muito provável que a legislação internacional acerca dos crimes de genocídio seja uma das razões que impedem o reconhecimento, apesar das pressões políticas internacionais. Afinal, nesse caso caberiam indenizações e outras punições na forma da lei. Entende-se que não há interesse e pretende-se evitar esse transtorno. Estas questões são o objeto deste estudo que tem como objetivo empreender o mapeamento das múltiplas versões procurando reconstituir os caminhos da polêmica. Temos consciência de que estamos diante de um tema tabu que, apesar de sua persistência, deve ser retomado pelos historiadores. Romper os silêncios propositais da história é, antes de mais nada, um direito que todo cidadão tem: da verdade e da memória histórica.

De forma a atender os nossos pressupostos aqui nomeados, estruturamos esta dissertação em três capítulos:

1) (Con)vivência e (In)tolerância: onde, através de uma retrospectiva histórica procuramos demonstrar o processo de inserção dos armênios e gregos no contexto da formação do Império Otomano, situações de convivência com grupos distintos por sua religião, poder econômico e proximidades com o poder político, assim como situações de intolerância que colaboram, ao longo dos séculos, para instigar o ódio aos gregos e armênios.

2) Anos Selvagens - 1876 a 1923: neste capítulo efetuamos uma comparação entre as diversas versões acerca dos acontecimentos que levaram à morte milhões de cristãos no Império Otomano, contrapondo opiniões de diversos autores, de modo a permitir uma análise mais global dos fatos. Associamos também os fatos históricos relativos à comunidade grega do Império Otomano, mostrando a semelhança do modus operandi, fato que permite ratificar a intenção genocida em relação aos "cristãos" do Império.

3) Acordos e acertos no pós-guerra - a luta pelo reconhecimento: onde discorremos sobre as dificuldades enfrentadas pelos armênios e gregos que procuram meios para provar o crime de genocídio diante da negação turca. Apresentamos a posição de diversos estudiosos quanto ao reconhecimento e a política de bastidores que contamina até mesmo a comunidade acadêmica. Por fim, discorremos sobre os efeitos nocivos do negacionismo sobre o ser humano. 


\section{I - (CON)VIVÊNCIA E (IN)TOLERÂNCIA}

\section{1 - Grandes Impérios da Antiguidade - Roma e Pérsia}

Para compreendermos o complexo emaranhado de razões e escusas que culminaram com os fatos históricos objetos deste estudo, procuramos analisar os relacionamentos entre os povos da região geográfica em que ocorreram os fatos históricos em questão: Mesopotâmia, Anatólia, Oriente Próximo, Balcãs. Enquanto espaços disputados por grupos distintos desde o início das civilizações e, de certo modo, até os dias de hoje, merecem nossa atenção. Tais conflitos, em diferentes momentos, aguçaram o ódio e ações de violência que culminaram nos atos identificados como "Genocídio Armênio".

Antes de qualquer entendimento, é preciso ter em mente que estamos tratando de um enorme território onde conviveram, desde a antiguidade, diferentes povos, distintos por suas culturas e idiomas. Estavam subordinados, de um modo ou de outro, em maior ou menor grau, a algum tipo de autoridade política, algum grande e poderoso império, cuja capital ou centro de poder estava, quase sempre, fora dessa região.

O primeiro movimento em direção a uma unificação cultural aconteceu com a helenização, consequência das conquistas de Alexandre, o Grande (335a.C.). A partir desse momento, surgiram grandes cidades segundo o modelo grego vigente, onde se falava o grego e se cultuavam deuses gregos. ${ }^{28}$ No século I d.C., grande parte da região passou para o domínio dos romanos, responsáveis por uma certa paz e prosperidade que persistiu por alguns séculos. Nesse momento, a polarização do poder estava entre Roma e os Persas ${ }^{29}$. Entre esses dois impérios e subordinados a um ou a outro, encontravam-se vários povos, dentre os quais, os armênios. A constante troca de poder e as alterações das fronteiras exigiam novos aprendizados, de modo a garantir para si próprios uma sobrevivência menos atribulada.

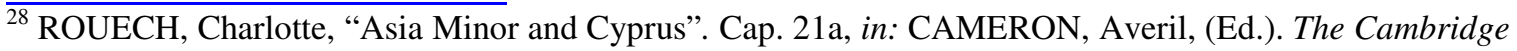
Ancient History - vol 14 - Late Antiquity: Empire and Sucessors, A.D. 425-600. Cambridge, Cambridge University Press, 2008, p. 571-572.

${ }^{29}$ Muitos autores utilizam a denominação "persas" também para seus sucessores, os Pártios e os Sassânidas. Em algumas obras também pode-se encontrar a denominação "iranianos”, com referência ao mesmo povo.
} 
1 - Oriente Próximo em 540 a. C.

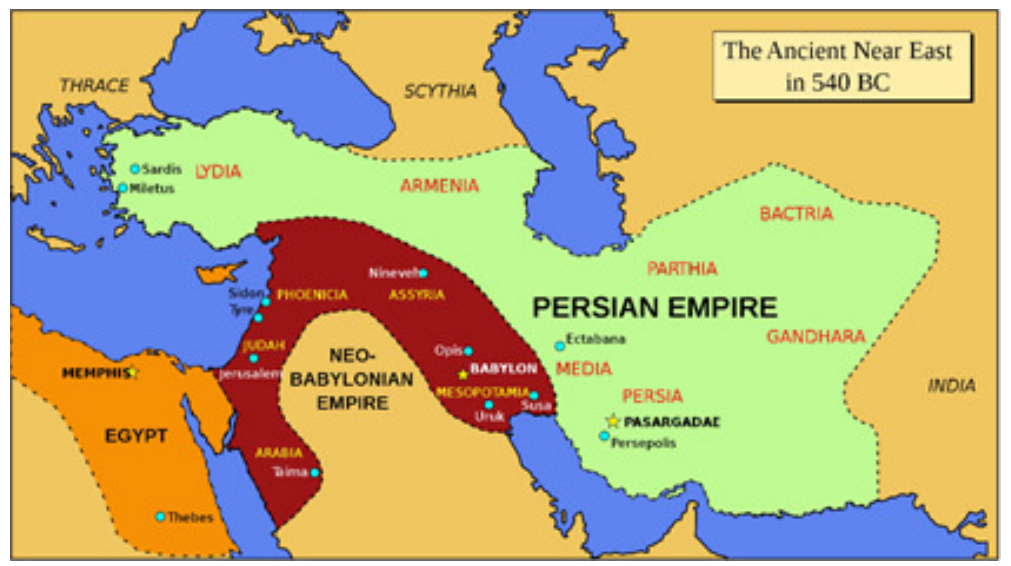

Reproduzido de:

http://commons.wikimedia.org/wiki/File:Ancient_near_east_540_bc.svg

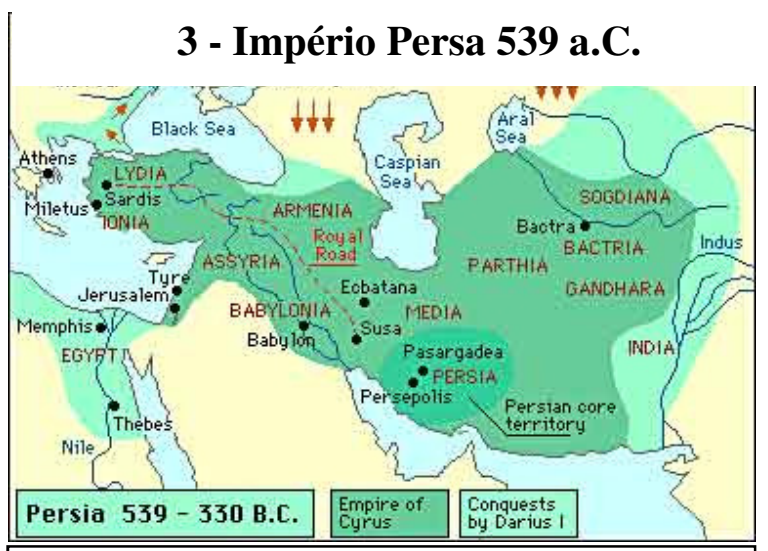

Reproduzido de: http://www.roman-

empire.net/maps/empire/extent/trajan.html

Reproduzido de:

http://www.ushistory.org/civ/4e.asp

2- Império Romano em 116 d. C.

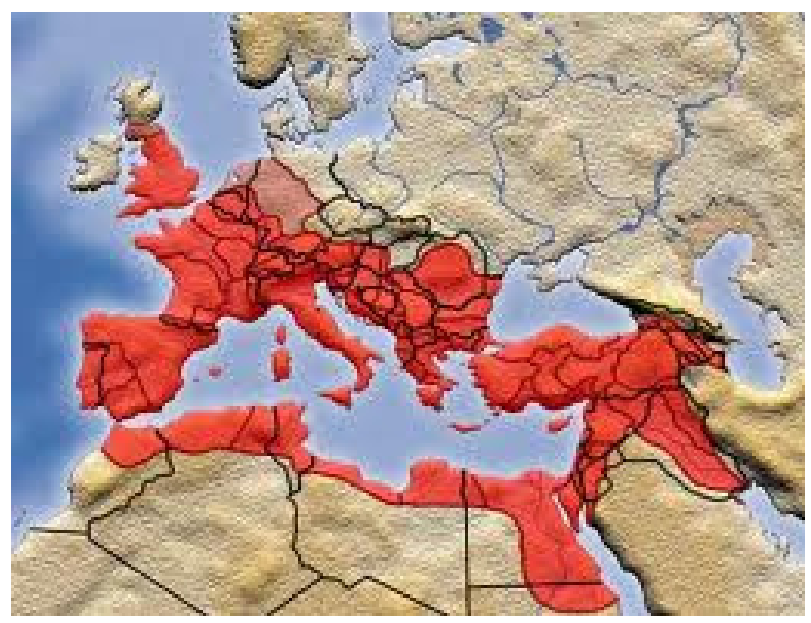


A palavra Armênia já aparece nos mapas de 540 a.C., mas sua definição é bastante complexa. Segundo Thompson ${ }^{30}$, é difícil saber se o termo se refere a uma entidade geográfica - nesse caso, não há uma definição de fronteiras - ou a um povo com laços comuns. $\mathrm{O}$ autor considera que seria necessário esclarecer quais são os laços, se linguísticos, religiosos, culturais ou políticos. Como tantos outros povos, os armênios procuravam manter boas relações com as autoridades locais. A força da cultura persa (iraniana) e os laços de amizade entre a nobreza armênia e o Irã faziam deles um aliado incerto para os romanos, apesar da conversão do Rei Tiridates ao cristianismo, provavelmente em 314 e a organização de uma igreja estruturada. Na verdade, a conversão do rei e a consequente cristianização do povo (ao menos oficialmente) complicou a situação dos armênios, pois a partir daí os Shás iranianos começaram a suspeitar da lealdade armênia. Tal fato levou inclusive a mais uma das muitas guerras entre os impérios na época de Constantino ${ }^{31}$. O mais conhecido dos imperadores romanos, que trouxe a capital do império para o Oriente (Constantinopla) e estava empenhado na difusão do cristianismo, enviou uma carta ao rei da Pérsia, Sapor, "sugerindo" que o mesmo fosse gentil com seus súditos cristãos. Como provavelmente era esperado, o persa imediatamente ocupou a Armênia e deu a Constantino a oportunidade de levar ao trono armênio o seu sobrinho Hannibaliano. ${ }^{32}$

Em 387, a Armênia foi dividida em duas monarquias, com distintas esferas de influência: uma iraniana, a leste; e outra, bem menor, romana, a oeste. Entretanto, essa divisão não resolveu a "questão armênia"33. Tanto Roma quanto a Pérsia seguiram considerando a Armênia um vizinho difícil. Apesar dessa situação desfavorável, a Ásia Menor esteve em relativa paz até o século VI. As invasões dos inimigos não alcançavam o interior da Anatólia, dando aos seus habitantes maior possibilidade de desenvolvimento sociocultural. Alguns arqueólogos consideram que houve uma escalada da insegurança na área a partir do aumento de construções de fortificações nas cidades, a partir de 570, embora seja difícil datar as fortificações. Na década de 570 há registros de um influxo de refugiados oriundos da Pérsia, o que teria desencadeado uma onda de fome. ${ }^{34}$ Outra ameaça externa eram os beduínos, povos nômades que viviam no deserto e conseguiam evitar facilmente as patrulhas de fronteira romanas.

\footnotetext{
$\overline{30}$ THOMPSON, R. W. "Armenia in the Fifth and Sixty Century" cap. 22b, in: CAMERON, op. cit., p. 662. ${ }^{31}$ Constantino o Grande, imperador romano e fundador da cidade de Constantinopla, em 330d.C.

32 JONES, AHM. The Later Roman Empire, 284-602, vol 1. Baltimore, University of Oklahoma Press, 1964, p. 101.

${ }^{33} \mathrm{O}$ termo 'questão armênia' será muito utilizado no futuro, aparentemente com o mesmo sentido. Neste caso, o autor refere-se a questão das lealdades à autoridade vigente e a percepção dos governantes em relação a elas.

${ }^{34}$ ROUECH, C, op. cit., p. 577.
} 
A partir do século VII, a vida começou a mudar. As invasões pártias tornaram-se mais frequentes e o exército romano de Heráclius se fazia mais ativo na região. Nesse momento, locais como Chipre, não regularmente utilizados para manobras militares, começaram a receber um contínuo influxo de pessoas deslocadas. ${ }^{3536}$ Nesse momento também se deram alterações nas sociedades urbana e rural: algumas cidades declinaram a ponto de desaparecer, outras se tornaram nada mais que um ponto de trocas de mercadorias. O poder político se transferiu para o campo, com foco nos senhores de terras. Essa alteração foi auxiliada pela disseminação do cristianismo, que permitiu a constituição de locais de culto nas pequenas vilas. No caso dos armênios, os senhores de terras representavam famílias da nobreza, conhecidos como 'príncipes', não necessariamente ligados à família real, mas detentores de poderes e privilégios reconhecidos tanto pelo Império Romano, quanto pelos persas.

A divisão entre os povos nessa área era muito mais cultural que étnica. Na prática, separavam-se os povos de acordo com o idioma, sendo mais comuns o grego, o siríaco e o árabe. A divisão linguística favorecia a separação geográfica, uma vez que o grego, por exemplo, era falado mais comumente nas grandes cidades ao longo da costa mediterrânea, enquanto o siríaco era usado no interior, especialmente nas pequenas vilas e no campo, nas regiões da Síria e no leste do Império. Até o século VI, o árabe era utilizado pelas tribos nômades que viviam nas bordas do deserto. Havia ainda algumas importantes comunidades judaicas, principalmente nas grandes cidades de Antioquia e Edessa.

A tranquilidade política nestas regiões, entretanto, era relativa, não significando paz ou ausência de confronto. A disseminação do cristianismo e a adoção desta fé como religião estatal(romana), a partir do reinado de Constantino I (324 d.C.) trouxe consigo os conflitos religiosos. Consideramos que as divergências que iriam culminar na "genocídio armênio" têm aqui suas raízes mais longínquas.

\section{2 - Divergências religiosas}

Inicialmente, a religião trouxe divergências para as terras romanas do Oriente, expressivas do embate do cristianismo imposto e recompensado pelo imperador e o paganismo arraigado na vida social. Apesar das proibições, os cultos pagãos persistiram, principalmente no campo, por séculos. Em Edessa, centro espiritual da Cristandade Siríaca,

\footnotetext{
35 Idem, p. 586.

${ }^{36}$ Em muitas obras que tratam dos séculos XIX e XX, podem ser encontradas referências à "antiga prática" de deslocamento de populações com fins de engenharia demográfica. É interessante notar que a prática de fato já existia desde o império romano tardio.
} 
sacrifícios a Zeus eram realizados ainda no final do século VI. Com os constantes embates entre os impérios e as mudanças de governantes, a religião do vencedor era quase sempre imposta aos subordinados, instigando conflitos e perseguições. A maior questão religiosa, entretanto, estava dentro da própria comunidade cristã. Desde o primeiro Concílio de bispos cristãos, conclamado pelo imperador Constantino em 325 em Nicéia, verificou-se a ausência de unidade dos dogmas a serem perpetuados pela Fé Cristã. Estes foram sendo construídos ao longo da história, em vários concílios que geravam conflitos entre os bispos, além de expulsões e assassinatos.

Um dos concílios determinantes para a História e que pretendemos acompanhar neste estudo, foi o de Calcedônia, em 451. Nesta reunião, a discussão sobre o entendimento do mistério da Reencarnação de Cristo dividiu literalmente as igrejas. Os Monofisitas, que acreditavam na natureza divina única de Cristo, afastaram-se daqueles Diofisitas, que preferiam sustentar a tese da natureza divina e humana de Cristo. Esta separação foi ainda mais importante, pois se fazia acompanhar de uma questão linguística: a doutrina monofisita era tratada principalmente em siríaco, enquanto os Diofisitas (também chamados de calcedônios, por terem acatado as definições estabelecidas nesse concílio) em geral se encontravam entre as elites urbanas que falavam o grego. Dependendo da fé do imperador, podia haver perseguição de um ou de outro grupo, o que colaborou ainda mais para o afastamento entre as comunidades. Na Armênia oriental, havia cerca de 50 famílias nobres, cada qual com sua própria força militar. Após a queda da família imperial, essas famílias procuraram aproximar-se de Roma ou da Pérsia, de acordo com interesses pessoais, conduzindo uma política externa individual. Historiadores armênios dos séculos V e VI ressaltam o papel "nacional" da Igreja Católica/Ortodoxa, mas deixam de informar que os bispados foram estabelecidos entre os nobres, o que reforçava a autoridade desses príncipes. ${ }^{37}$

Entretanto, a fé cristã não era um 'modo de vida ancestral' na Armênia. Para muitos, o cristianismo era uma fé estrangeira, que veio da Síria ou da Ásia Menor. No quarto século ainda não havia um meio escrito para registro na própria língua, o que dificultava a difusão entre a população, que seguia costumes de tradição iraniana. A escrita armênia foi criada por Mastros em 400 e seus discípulos foram enviados à Síria e à Ásia Menor para aprender o siríaco e o grego, além de fazer traduções dos livros necessários para a igreja. Mais tarde, o grupo também produziu obras próprias de filosofia, gramática, retórica e pesquisas científicas, criando segmentos para a construção de uma identidade armênia.

\footnotetext{
${ }^{37}$ THOMPSON, R. W, op. cit., p. 664.
} 
Como aconteceu em outros locais, a Igreja na Armênia também se tornou o único caminho para os interessados em aprender, "só a Igreja oferecia possibilidade de avanço para os ambiciosos e o paraíso para os estudiosos". ${ }^{38}$ Com isso, a importância do relacionamento da Igreja Armênia com o resto do mundo grego bizantino tornou-se significante. Entretanto, apesar de sua admiração pelo conhecimento grego, sua aproximação com Constantinopla era, no mínimo, cautelosa. A influência dos rituais da Igreja Síria, entre outras querelas, afastavam os armênios da linha seguida pela capital do império: um cisma era esperado.

No concílio de Éfeso, reunido em 431, o bispo Nestorius e outros antioquinos foram condenados. Entretanto, as ideias nestorianas circulavam na Armênia. Vinte anos depois, o patriarca armênio não enviou representação ao já citado Concílio de Calcedônia. A Igreja Armênia, portanto, não considerou as decisões desse concílio, tendo, nesse caso, se posicionado "contra" a fé imperial. Mas, como os armênios haviam desenvolvido uma tradição própria na arquitetura eclesiástica e na literatura, não era possível dizer que "se opunham" ao imperador, apenas que eram "diferentes". Essa situação os colocava em uma posição peculiar: eram 'protegidos' pelo imperador e também pelo Shá, sendo ao mesmo tempo um estorvo para ambos, como pode-se apreender do trecho da carta apócrifa que um historiador armênio conhecido como Sebeos afirma ter sido enviada por Mauricio (imperador romano de 582 a 602) a Khusro (rei da Pérsia):

'Eles [os armênios] são uma nação perversa e desobediente, que fica entre nós e nos perturba. Eu vou reunir os meus e mandá-los para a Trácia. Você reúne os seus e os manda para o leste. Se eles morrerem, são nossos inimigos que morrem. Se matarem, matam nossos inimigos. Então poderemos viver em paz. Porque se eles permanecerem em nossas terras, não haverá repouso para nós' ${ }^{39}$

A conversão dos armênios ao cristianismo mudou gradualmente as suas relações com o Irã. Sua fé também manteve os armênios à parte da igreja imperial de Constantinopla. Muitos armênios encontraram fama e fortuna no império bizantino, mas a Armênia como um todo nunca se integrou ao império de língua grega. Estas diferenças, ainda que sutis ou marginais, certamente contribuíram, ao longo dos séculos, para aprofundar as tensões.

\footnotetext{
38 Idem, p. 667.

${ }^{39}$ Sebeos, 86, apud THOMPSON, idem, p. 674.
} 


\section{3 - Maomé e a difusão do Islã}

À época do nascimento do Profeta Maomé (570), a população na península arábica era, em geral, politeísta, ainda que existissem tribos judaicas e cristãs instaladas na região. A desértica região era pouco frequentada, a não ser por caravanas gregas que faziam o comércio com o Oriente. Era, portanto, de pouca importância para os dois poderosos impérios da época. Aos 40 anos, Maomé começou a receber visões e ouvir vozes que julgava serem do Arcanjo Gabriel. Tais revelações foram anotadas pelos parentes e amigos do Profeta, mais tarde seguidores de sua nova fé. Em 662, trinta anos após sua morte, o Alcorão, livro sagrado do Islã, chegou a sua versão definitiva.

A partir de 633, um ano após a morte do profeta Maomé, começaram as invasões muçulmanas ao território bizantino, a princípio, procurando tomar vilas e pequenas cidades fronteiriças. Aparentemente, após uma grande vitória em 636, a entrada de muçulmanos nesses territórios foi pacifica, pois ocupavam uma terra pouco habitada, frequentada apenas por nômades. Muitas das mudanças atribuídas aos muçulmanos, como o declínio das cidades costeiras e a evolução das formas de urbanização, eram apenas continuações de tendências já estabelecidas na antiguidade tardia. ${ }^{40}$

Maomé foi sucedido por seus parentes, que controlaram a Península Arábica e avançaram em direção à Pérsia e à Síria, dominadas em pouco tempo por Omar. A partir de 660, a dinastia Omíada tomou o poder e seguiu com as conquistas, anexando a Palestina, o restante da Pérsia e o norte da África, passando em pouco tempo para a Espanha.

Em 750, os Omíadas foram substituídos pela dinastia de Abou Abas, os Abássidas, que transferiu a capital de Damasco para Bagdad. Um acontecimento de grande importância para o desenrolar dessas conquistas foi o aparecimento dos soldados Turcos, a partir de 830, como escravos (Mameluks). Inicialmente escolhidos como escravos, os soldados turcos logo ascenderam a líderes dos exércitos do Califado. Até o ano de 1055, muitas divisões ocorreram no califado muçulmano. Nesse ano, o chefe seljuk Togul Beg foi coroado califa em Bagdad. ${ }^{41}$

Enquanto isso, do outro lado da fronteira, o Império Bizantino crescia em poder, chegando a ser conhecido (na Europa) como o Estado mais poderoso do mundo em 1054. Para resolver problemas demográficos e fiscais, assim como afastar a oposição religiosa, o governo bizantino usava a política de transferência de população, às vezes em grandes números, de algumas partes da Ásia Menor para os Bálcãs, para repopular a região devastada

\footnotetext{
${ }^{40}$ WHITBY. op. cit., p. 610.

${ }^{41}$ ARRUDA, José Jobson de A. História Antiga e Medieval. São Paulo, Ática, 1982. p. 310-311.
} 
por guerras e invasões ou no sentido contrário, dependendo do interesse. ${ }^{42}$ Nesse mesmo ano, ocorreu o cisma entre as igrejas do Ocidente e do Oriente, revelando antigas desigualdades entre as partes latina e grega do império romano que, em última instância, contribuíram para o saque de Constantinopla durante a Quarta Cruzada, em 1204. ${ }^{4344}$

Um acordo entre um príncipe armênio e o Califa em 650 colocou fim à hegemonia romana na Armênia e apesar dos esforços bizantinos para reconquistar sua autoridade, o domínio árabe permaneceu firmemente definido. A autoridade islâmica se fazia através dos príncipes locais até que, em 770, uma grande revolta contra impostos abusivos quebrou essa regra. A revolta foi aplacada brutalmente e muitos nobres desapareceram. Como resultado, duas famílias nobres restantes, os Bagratuni e os Artsruni, conseguiram impor sua superioridade nas respectivas áreas de influência, porém os califas árabes começaram a assentar árabes e outros muçulmanos nas terras armênias, favorecendo, consequentemente, a islamização da região. Apesar disso, os Bagratunis mantiveram o controle, sendo reconhecidos pelo Califa como 'príncipe dos príncipes' e, em 884, Azor Bagratuni foi nomeado Rei da Armênia. ${ }^{45}$

Durante as guerras de reconquista dos bizantinos, muitas terras dessa região, dominadas pelos muçulmanos, retornaram às mãos de Constantinopla. Um tratado de aliança foi assinado em 970 entre o reino da Armênia e o Império Bizantino. Os Seljuks mantiveram seu poder, conquistando e perdendo território e poder em momentos alternados, até 1308. Alguns anos antes, um novo poder havia surgido do Oriente - os Turcos Öğuz, chamados Otomanos segundo o nome do fundador da dinastia, Osman I. Muitas tribos lutavam em nome do Islã contra o inimigo cristão, porém, em pouco tempo, os otomanos, mais organizados, conquistaram grande parte das terras bizantinas com muita eficiência. O domínio sobre tão diferentes povos exigiu do sultão uma política para lidar com os chamados infiéis sob seu

$\overline{42}$ HALDON, John. The Palgrave Atlas of Byzantine History. New York, Palgrave Macmillan, 2005, p. 76.

${ }^{43}$ Idem, p. 96.

${ }^{44}$ A Quarta Cruzada foi um momento de virada na sorte do império bizantino, embora este ainda tenha durado mais de dois séculos. O Papa Inocêncio III recrutou italianos e franceses para ir à terra santa por mar, passando antes pelo Egito. Para isso, precisavam de navios, que contrataram dos venezianos por 85 mil marcos, uma quantia astronômica, muito além do que até mesmo o Papa podia pagar. Aléxios, o filho do ex-imperador bizantino Isaac II, agora deposto e exilado, ofereceu aos cruzados pagar a dívida com os venezianos se estes fossem para Constantinopla e restaurassem no trono bizantino a ele ou ao pai. Essa proposta era muito interessante para o Papa, pois um imperador bizantino que devesse seu trono aos soldados do Papa seria muito mais benevolente para com a ideia de reunir novamente as igrejas (divididas oficialmente desde 1054) sob a autoridade papal. Os cruzados aceitaram, chegaram a Constantinopla em junho de 1203 e restauraram Aléxios e o pai no trono. Mas estes não conseguiram levantar o dinheiro para cumprir a promessa. Tentaram aumentar as taxas, mas a população se revoltou. Em abril de 1204, Isaac já estava morto e Aléxios fugiu. Então os cruzados tomaram a cidade e a saquearam por três dias, em completa selvageria. Muitos historiadores apontam o saque de Constantinopla como a principal razão para o enfraquecimento do Império, que a partir daí não teria mais condições de enfrentar a força crescente dos exércitos otomanos.

${ }^{45}$ HALDON, op. cit., p. 103. 
comando. A solução foi encontrada na Lei Sagrada, que especifica bastante detalhadamente como deve se portar o infiel que vive em território do Islã e como estes devem ser tratados.

De acordo com o Alcorão, não existe outro Deus senão Alá. Essa afirmação categórica obviamente exclui qualquer possibilidade de outros deuses, ainda que secundários, como ocorre nas religiões politeístas. Afirmar o contrário é desrespeitar o Islã, configurando-se como pecado mortal. Por conta disso, os politeístas habitantes de regiões conquistadas pelo Islã deveriam ser imediatamente convencidos de seu erro e repará-lo, convertendo-se à verdadeira fé. Caso não pudessem ser convencidos, deveriam ser mortos ou, na melhor das hipóteses, escravizados. Entretanto, em alguns locais onde o povo conquistado representava uma maioria muito expressiva, como na Índia por exemplo, o politeísmo pode ser mantido.

Já os chamados "povos do Livro", ou que professavam religiões da Revelação (cristãos e judeus), gozavam de certas distinções de tratamento. O quanto essas distinções podem ser consideradas tolerantes, depende da definição de "tolerância". Antes de mais nada, é preciso lembrar que a atitude tolerante com relação ao outro não era algo natural nesse momento da história mundial. Se assumirmos tolerância como a "ausência de discriminação", o Islã não poderia ser chamado de tolerante. Mesmo porque seria impossível: a discriminação dos não-crentes era inerente ao sistema de governo. Por outro lado, se consideramos tolerância como "ausência de perseguição", então pode-se afirmar que o domínio muçulmano foi bem tolerante durante longo tempo, bem mais que seus vizinhos cristãos, inclusive. Embora não seja uma religião igualitária, a mobilidade social era muito mais provável no Islã que fora dele ${ }^{46}$.

As regiões conquistadas pelo Islã, principalmente no Oriente Médio, haviam sofrido por séculos pois tanto cristãos quanto zoroastristas tentavam impor sua fé aos dominados, colecionando desafetos. O Islã não repetiu esses erros. Para muitos, como os judeus, a conquista pelo Islã foi apenas uma mudança de senhores, e para um senhor mais ameno.

\section{A Dhimma}

Desde o início definiram-se três grupos de desiguais na sociedade islâmica - os escravos, as mulheres e os não-crentes. Todos eles estavam inseridos de certa maneira no sistema e eram aceitos, pois tinham utilidades. Destes, os não-crentes eram os únicos que podiam mudar sua condição, a qualquer tempo e por sua própria vontade. A conversão ao Islã

\footnotetext{
${ }^{46}$ Link da Foundation of Hellenic World: http://www.fhw.gr/chronos/11/el/en/religion/conflict/index.html
} 
podia alçar o infiel à mesma categoria dos muçulmanos livres. Entendia-se com isso que o infiel estava na situação de subordinado porque assim o desejava. ${ }^{47}$

A relação entre o estado muçulmano e as comunidades não-crentes era regulada por um pacto chamado Dhimma e os beneficiários desse pacto eram conhecidos por Dhimmis (ahl aldhimma ou povos do pacto). Os termos desse acordo estavam bem fundamentados nas leis sagradas, em detalhes. $\mathrm{O}$ acordo permitia que não-crentes vivessem em território muçulmano e organizassem suas comunidades, em torno de suas igrejas. Estas comunidades eram os Millets. A autoridade máxima dentro do millet era o sacerdote e os assuntos internos podiam ser resolvidos sem a intervenção do governo muçulmano. Os dhimmis eram considerados como cidadãos de segunda classe do império. Ainda assim, muitos eram médicos, grandes comerciantes, banqueiros, tinham muitos bens. Como não podiam portar armas, nem servir ao exército, podiam dedicar-se com mais tempo às atividades profissionais e chegavam mesmo a ser mais abastados que muitos muçulmanos, fato que podia inspirar inimizades. ${ }^{48}$ Veremos adiante como as diferenças, principalmente econômicas, entre os dhimmis e os muçulmanos tiveram forte influência na escalada dos conflitos.

\section{4 - Ascensão e declínio Otomano}

Os herdeiros de Osman $^{49}$ viveram séculos de glória e multiplicaram suas vitórias. Constantinopla caiu aos seus pés e as fronteiras otomanas não paravam de se expandir. Parecia mesmo que a Casa do Islã triunfaria e abrangeria todo o mundo, como prega o Corão. Depois de envolver toda a Ásia Menor, voltaram-se para a Europa e seguiram ganhando terreno. Os guerreiros muçulmanos chegaram até aos portões de Viena, onde foram barrados. No ano de 1683, após quase dez séculos de expansão constante, o Islã encontrou um obstáculo intransponível: as terras europeias não se entregariam facilmente às tropas de Maomé. A maioria dos historiadores aponta esta batalha como o início da lenta decadência do Império Otomano.

\footnotetext{
${ }^{47}$ Sobre as restrições aplicadas aos Dhimmis, ver: http://sri000.wordpress.com/2013/02/26/the-conditionsdhimmis-have-to-live-by-under-islamic-sacred-law-sharia/

${ }^{48}$ DOBKIN, Marjorie H. Smyrna 1922, the Destruction of a City. New York, Newmark Press, 1998, p. 25.

${ }^{49}$ Osman era o Khan, o líder da tribo que leva seu nome - Osmanlis ou Otomanos.
} 


\section{4 - Conquistas Otomanas}

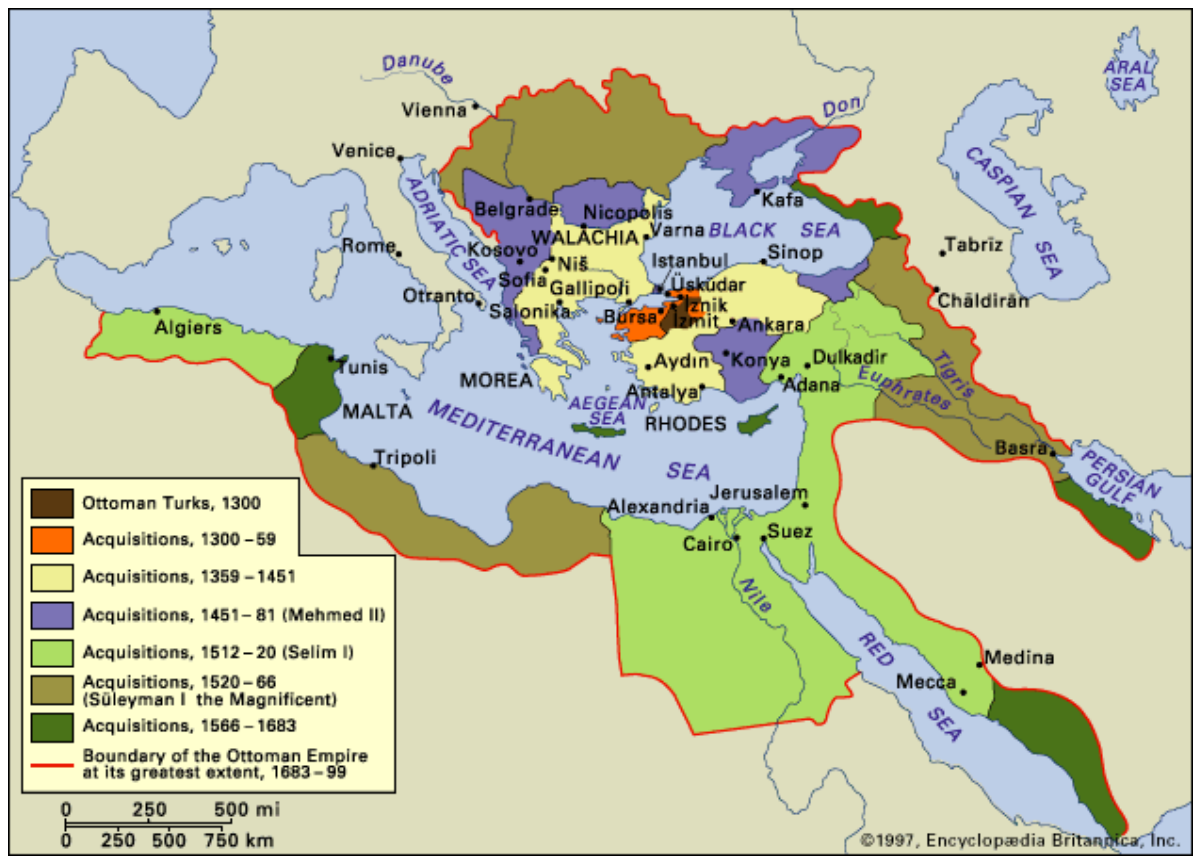

Reproduzido de:

http://www.theopavlidis.com/MidEast/part50.htm

No final do século XVII, o Império Otomano era formado por 39 províncias, dentre as quais quatro tinham predominância grega: Rumélia, Peloponeso, Chipre e Creta. ${ }^{50}$ Para os dhimmis de Constantinopla, a vida era bem aprazível, o que não significa que fosse assim em todo o Império. A riqueza para os otomanos vinha da terra conquistada, que era trabalhada pelos agricultores gregos (90\% da população). As áreas planas da Tessália e Macedônia produziam muito trigo, milho e algodão, que abastecia Constantinopla. O Peloponeso era famoso pelos figos e oliveiras. A vida nas cidades era regulamentada por um sistema de Associações de Ofício, às quais todo artesão ou comerciante deveria estar afiliado e cuja estrutura oferecia poucas possibilidades de ascensão profissional. O sistema de associações já era utilizado durante o período bizantino e foi incorporado pelos otomanos, por ser uma excelente forma de controlar as finanças do império. Os otomanos, por falta de interesse ou por motivos religiosos, deixavam o comércio nas mãos dos gregos, judeus, armênios e levantinos $^{51}$. Fica evidente, entretanto, que os otomanos tinham plena consciência da importância do comércio e das cidades onde ele florescia e, é claro, do imposto a ser cobrado sobre ele.

\footnotetext{
${ }^{50}$ BREWER, David. Greece. The Hidden Centuries - Turkish Rule from the Fall of Constantinople to Greek Independence. New York, I.B.Tauris, 2010, p. 99.

${ }^{51}$ Levantinos são estrangeiros, cidadãos de outros países, ingleses e franceses, por exemplo, que viviam no Império Otomano.
} 
"O pensamento econômico otomano estava intimamente relacionado com o conceito básico da sociedade no Oriente Médio. De acordo com esse conceito, o objetivo final do Estado era a consolidação e a extensão do poder dominante, e o único meio de alcança-lo era ter uma rica fonte de rendimentos. Isso, por sua parte, dependia das condições que faziam as classes produtivas prósperas" ${ }^{, 52}$

Para a maior parte dos gregos, o domínio otomano era apenas mais um domínio, como o dos francos ou dos bizantinos. O domínio turco, entretanto, trouxe certa estabilidade que, até então, eles não conheciam. A política de tolerância tinha suas razões - eram muito mais não-muçulmanos que muçulmanos, os súditos do sultão. Além disso, os dhimmis podiam servir ao império com sua produtividade: pagavam taxas, eram marinheiros e comerciantes ou financistas, coisas de que o estado precisava. Em 1699, pela primeira vez, o sultão assinou um tratado de paz em desvantagem: em Karlowitz, a Hungria, Belgrado e o território ao sul até Skopje foram cedidos à Áustria e o Peloponeso, a Veneza. Essas perdas, no entanto, foram temporárias. Em 1715 os otomanos expulsaram os venezianos e, em 1739, receberam de volta Belgrado e a maior parte do território perdido.

A Rússia era um inimigo constante e ameaçador. A guerra de 1768-1774 foi um desastre para o Império Otomano. Ao assinar o ainda mais humilhante tratado de KutchukKainardji (1774), além de perder o território da Romênia, o sultão concedeu muitos direitos de navegação à Rússia, o que afetou positivamente a comunidade grega. Ficaram autorizados também os navios gregos com bandeira russa - uma das importantes fontes de riqueza para os mercadores gregos. Além disso, esse mesmo tratado concedeu à Rússia o direito de proteger os súditos cristãos do sultão. ${ }^{53}$ Associada às derrotas militares estava a dificuldade econômica do Império Otomano. Desde a conquista da América Espanhola e da entrada de grandes quantidades de prata nos mercados europeus, a moeda otomana, de prata, perdeu valor e a inflação tornou-se incontrolável. ${ }^{54}$ A derrota definitiva nos planos expansionistas otomanos, às portas de Viena, fez com que o Império se voltasse para dentro. Sem perspectivas para a ampliação da Casa do Islã, o exército perdeu o interesse em atualizar sua tecnologia bélica. Com isso, começou a perder terreno para o Ocidente, que se aprimorava cada vez mais. Perceber isso era um golpe para a moral dos soldados. Este foi, segundo Bernard Lewis, um dos principais motivos do declínio do Império ${ }^{55}$.

\footnotetext{
$\overline{52}$ INALCIK, The Ottoman Empire: Conquest, Organization and Economy, section X, p. 217, apud BREWER, op. cit., p. 98.

55 LEWIS, Bernard - The Emergence of Modern Turkey. 3a. Ed. New York, Oxford University Press, 2002, p. 25.
} 
Outra razão a ser considerada era o desequilíbrio social reinante. Os muçulmanos tinham status social, mas somente conheciam quatro profissões - a guerra, a religião, o governo ou a agricultura. Todas as profissões liberais, o comércio e as transações financeiras estavam nas mãos dos infiéis (gregos, armênios e judeus, principalmente), por serem “indignas” de um filho do Islã. Da mesma forma, um infiel não podia participar das decisões políticas. Com isso, a sociedade multifacetada otomana era formada por dois grupos distintos: 1- cidadãos de primeira classe, dominantes, governantes, mas iletrados e, em geral, pobres e 2- cidadãos de segunda classe, mas ricos e poderosos, com importantes contatos no Ocidente porém impedidos de tomar as decisões políticas necessárias para o desenvolvimento do país.

A essa realidade socioeconômica é preciso acrescentar o papel político-militar dos Janízaros $^{56}$, a tropa de elite do império, que não admitia modernizações, mas com força suficiente para depor ministros e, até mesmo sultões, e algumas associações secretas de jovens estudantes dispostos a mudar o mundo. Ao reunir todas essas peculiaridades, o Império Otomano chegou a seu ponto de cisão.

\section{As revoltas nacionalistas}

Uma gama de fatores implicaram nas origens dos movimentos nacionalistas que buscavam destaque no complexo território otomano. Dentro do império, haviam os mercadores que tinham maior contato com o Ocidente e viajavam com frequência à França ou à Inglaterra, e os filhos de famílias abastadas, que buscavam instrução em Paris ou Berlim. E, no contexto otomano, mercadores e famílias ricas que eram, na maioria, gregos, armênios ou judeus.

O contato com as ideias iluministas teve seu efeito, reunindo grupos de jovens preocupados em planejar o Estado ideal. No início do século XIX, surgiram várias sociedades secretas, seguidoras do modelo dos irmãos Carbonari ${ }^{57}$ da Itália, que produziam literatura, publicavam jornais provocadores, cujos membros viajavam a Paris para abastecer-se de cultura. Nos Bálcãs, a mais famosa e efetiva dessas sociedades foi a 'Philiki Etairia', em

\footnotetext{
${ }^{56}$ A tropa de Janízaros era formada, principalmente, pelos meninos cristãos requisitados pelo Devshirme: a cada ano eram convocados os meninos mais saudáveis e espertos, entre as famílias cristãs, para serem criados no palácio, como "filhos" do sultão. Estes meninos recebiam formação específica e eram convertidos ao Islã. Os Janízaros eram, de fato, a guarda pessoal do Sultão e os soldados mais bem treinados do Império.

${ }^{57}$ Carbonari Brothers, irmãos ou primos, como costumavam chamar-se, eram membros da sociedade secreta que floresceu na Itália e ficou famosa em 1818. Buscavam defender os direitos do povo contra todas as formas de absolutismo. Vindos de todas as camadas da sociedade, os Carbonari não hesitavam em pegar em armas e, se necessário, assassinar desafetos. http://www.globalsecurity.org/military/world/europe/carbonari.htm
} 
grego 'Sociedade de Amigos', criada em 1814 e responsável pelo levante de forças que resultaram na Revolução Grega. Mas, certamente, esses grupos encontravam dificuldades para enfrentar a máquina imperial, aproveitando-se da ajuda externa, que era oferecida, mas não sem outros interesses.

A falta de dinheiro afetava principalmente as tropas, insatisfeitas por serem mal pagas e disporem de poucos armamentos e, ainda, de péssima qualidade. As conquistas de território, que antes traziam novas riquezas ao império, haviam cessado. As novas terras adquiridas eram um dos meios pelos quais os soldados da cavalaria eram pagos por seu trabalho: o sultão lhes concedia 'timars', terras que podiam ser cultivadas (por gregos ou armênios) e das quais retiravam uma porcentagem da colheita. Sem poder lançar mão dessa "moeda", o Sultão era obrigado a pagar salários, geralmente muito baixos e sem regularidade. Isso tornava o exército um peso para o Estado e vice-versa.

Para conseguir levantar fundos, a Sublime Porta instituiu os coletores profissionais de imposto ('tax farmers', ou literalmente, fazendeiros de impostos) - que compravam o direito de coletar impostos da população de uma certa região. Tinham o dever de enviar ao sultão uma quantidade fixa de dinheiro, e o que excedesse essa quantidade, era seu lucro. Obviamente, em pouco tempo, esse precedente conduziu a um sistema viciado de exploração e corrupção, tolerado pela Porta, interessada nos resultados, mas que sacrificava sobremaneira o agricultor ou trabalhador comum. Quando se sabia que uma determinada área era promissora para esse negócio, os direitos de coletor eram vendidos por valores cada vez mais altos, exigindo ainda maiores esforços do camponês. Desse modo, o governo central não gastava para acionar a máquina coletora, mas perdia totalmente o controle para as elites regionais, enquanto que o trabalhador sofria com uma exploração que o governo não podia, ou não desejava, combater $^{58}$.

Em 1764, a imperatriz russa Catherine apoiou a ascensão de Stanislav Poniatovski, seu amante, ao trono da Polônia. Os poloneses se ressentiram e procuraram apoio otomano. $\mathrm{O}$ Sultão lançou um ultimato à Rússia para retirar suas tropas da Polônia e quando Catherine recusou, declarou guerra. Provavelmente, as razões do sultão não eram tão altruístas: buscava uma forma de chegar à guerra com a Rússia, pois estava certo da vitória, como aconteceu na última vez em que se enfrentaram. No entanto, o decurso da guerra não se mostrou tão favorável aos otomanos, revelando-se um péssimo negócio para o Sultão. Pelo Tratado de

${ }^{58}$ BREWER. op. cit., p. 155. 
Kutchuk-Kainardji, assinado em 1774, além de pagar uma indenização enorme, a Porta concedeu à Rússia benefícios inestimáveis: o direito de navegar e fazer comércio no Mar Negro e também o direito de defender os cristãos, mais precisamente os ortodoxos, habitantes do Império Otomano. Dupla vantagem para os gregos que encontraram um protetor a quem recorrer e ainda a oportunidade de enriquecer. A indústria marítima floresceu, junto com o comércio. ${ }^{59}$ Até mesmo os marinheiros gregos eram requisitados para a marinha turca, por suas qualidades no mar. A partir dessa vantagem comercial, a frota grega cresceu a ponto de se tornar a maior frota mercante, no início do século $\mathrm{XX}^{60}$.

A partir do início do século XIX, com a pressão econômica e o descontentamento da população com os governantes - os tax farmers elevavam arbitrariamente o valor cobrado. Começaram a surgir pequenos grupos de insatisfeitos que buscavam, principalmente nos princípios iluministas franceses, um meio de mudar sua realidade. É quando têm origem os movimentos nacionalistas nos Bálcãs, dentre os quais o levante sérvio (1815-17) e a revolução grega (1821-27), os mais conhecidos. A Moldávia e a Bósnia-Herzegovina conseguiram certa autonomia e o norte da África tornou-se presa dos imperialismos europeus. Estes movimentos levaram à perda consecutiva de vários territórios otomanos levando o pânico à Sublime Porta.

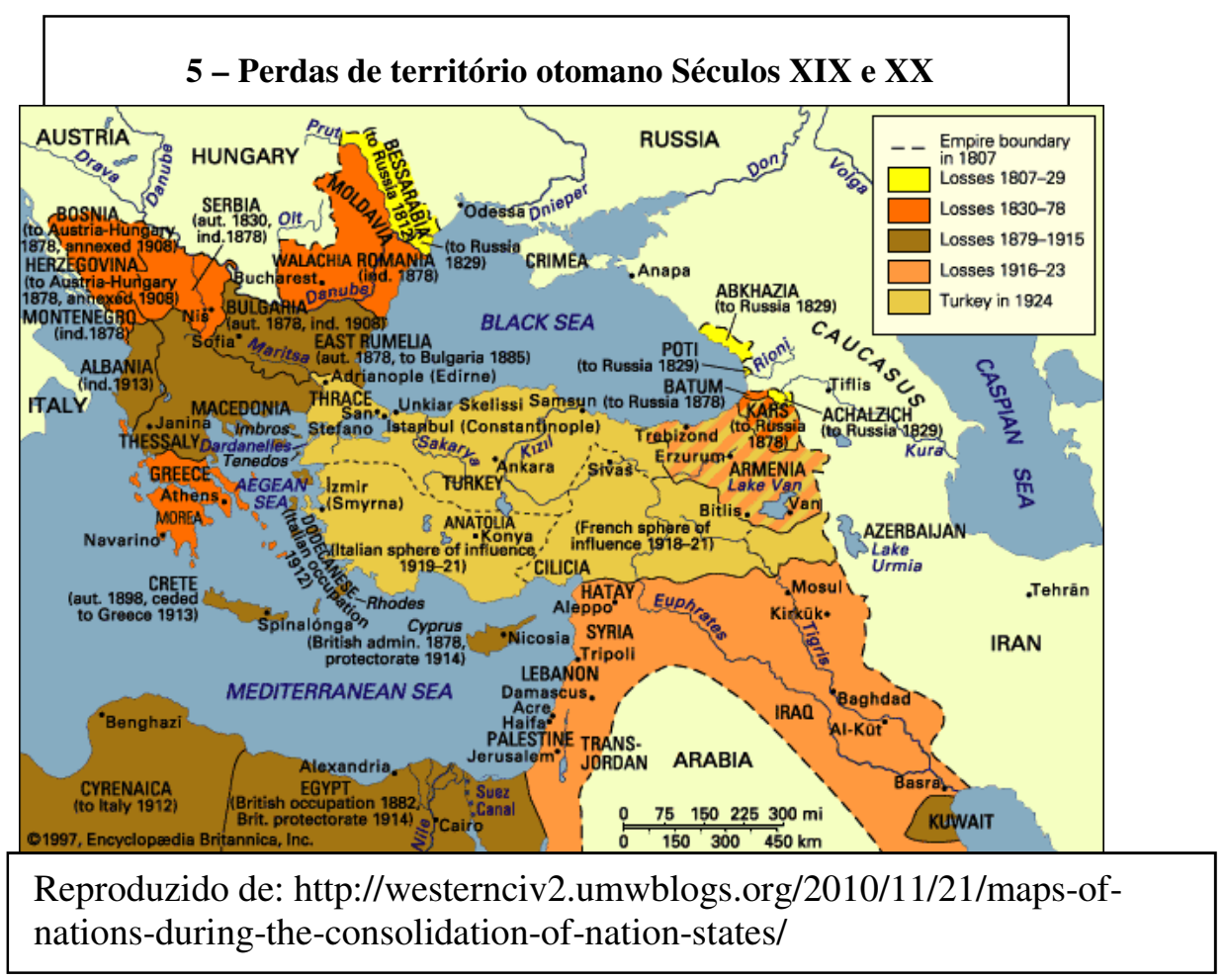

\footnotetext{
${ }^{59}$ É importante notar que os gregos e os armênios serão mais tarde acusados de enriquecer 'às custas' dos turcos e esta será uma das razões apontadas para a crescente animosidade entre esses povos.

${ }^{60}$ Fonte de internet: http://www.greece.org/poseidon/work/articles/polemis_one.html
} 
A independência dos territórios islâmicos, segundo Lewis, demonstra o estado debilitado da moral otomana. Os Pashas locais aproveitavam-se da fraqueza política e da distância do Sultão para promover revoltas e transformar suas províncias em principados independentes, como no caso do Egito (Ali Bey), da Síria (Ahmed Jezzar) e dos mamelucos de Bagdad e Basra. ${ }^{61}$

Assim como aconteceu com os cristãos, também os muçulmanos sentiram os ventos iluministas. O nacionalismo turco apareceu pela primeira vez na metade do século XIX, seguindo a tendência reformista inaugurada pelo sultão Selim. Com o fim do corpo de Janízaros, as reformas tornaram-se mais plausíveis e o Sultão Mahmud II empenhou-se nisso com afinco. Em 1839, com o objetivo de conter o declínio e as perdas territoriais, o Sultão Abdul Mecit I lançou um plano de reformas conhecido como Tanzimat, literalmente 'Reestruturação'. Concebido por pensadores turcos educados na Europa, como Ali Pasha, Fuad Pasha, Ahmed Cevdet Pasha e Midhat Pasha, e iniciado extraoficialmente pelo Sultão Mahmud II (o Reformador), o plano incluía a reorganização do exército, que passava a incluir os não-muçulmanos em seus quadros, garantias para a vida, honra e propriedades de todos os súditos, reorganização do sistema financeiro segundo o modelo francês, igualdade para os cidadãos de todas as religiões, abolição do imposto cobrado de não-muçulmanos, entre outras medidas bastante 'ousadas'. A igualdade de direitos para não-muçulmanos desafiava a lei islâmica que preconiza a tolerância aos infiéis desde que estes se submetessem à condição secundária. Desnecessário dizer que havia também muita pressão por parte das potências europeias, interessadas nestas reformas.

No entanto, essas medidas não foram bem aceitas pela maioria da população. Os muçulmanos ressentiram o término de sua superioridade e honra. O novo código civil, de 1850, copiado da França, criava condições para estrangeiros possuírem terras no império, bem como, dentro dos millets armênios e gregos, além de incentivar o crescimento e enriquecimento da burguesia. Este grupo também recebia influência das ideias políticas francesas, o que acabou levando a um movimento para a emancipação das organizações, mesmo dentro dos millets, fora do controle das respectivas igrejas. Após longas negociações,

${ }^{61}$ LEWIS, B. - The Emergence of Modern Turkey, op. cit., p. 37. 
o millet gregoriano armênio adotou constituição própria, que serviu de inspiração para o movimento constitucional otomano. ${ }^{62}$

A partir da Guerra da Criméia (1853-56) - cuja causa declarada era um conflito Franco-Russo entre católicos e ortodoxos pelo controle dos lugares sagrados da Terra Santa, e que resultou num tratado de Paz que incluiu o Império Otomano sem que o mesmo fosse consultado - o Império foi incluído no "Concerto da Europa", sistema encontrado para manter o equilíbrio de forças das potências. Apesar de aceito, sua fraqueza e pobreza fizeram do Império Otomano objeto de intriga diplomática. ${ }^{63}$ Seu envolvimento econômico com as potências europeias levou o Império a aumentar seu comércio, bem como seus empréstimos junto aos colegas europeus. A situação monetária tornou necessário e lucrativo o negócio bancário - os banqueiros armênios, gregos e judeus preferiam lidar com os juros do capital a investir em produção, cujo retorno era muito mais lento. ${ }^{64}$ Nesse momento surgem opositores às reformas em curso, tanto aqueles que desejavam permanecer na estagnação anterior quanto os que desejavam seguir em frente com a modernização, seguindo, porém, uma linha mais, por assim dizer, islâmica.

Jovens turcos de famílias ricas estudavam línguas europeias, com professores europeus, e viajavam pela Europa. Era inevitável que se sentissem atraídos pelas peculiaridades e diferenças entre o Ocidente e seu país. O que de mais peculiar poderiam encontrar que um governo parlamentar? ${ }^{65}$

Esses jovens formariam a elite letrada do país em mutação, até então inexistente. Possuíam condições para repensar seu papel na sociedade otomana e, no momento em que o sultão ameaçou tomar as rédeas do poder, se sentiram preteridos. Esses mesmos jovens formaram a oposição intelectual, divulgada por jornais distribuídos pelo Império, conquistando simpatizantes em toda parte.

Em 1859, durante o reinado de Abdul Mecit, aconteceu o incidente Kuleli, que ficou conhecido como o primeiro protesto liberal contra o absolutismo turco. Tratava-se de um plano para depor e, se necessário, matar o Sultão, mas o plano foi descoberto e seus organizadores exilados na Ásia. Embora pareça, este não foi um movimento revolucionário liberal. Os conspiradores atentavam contra o Sultão, mas pretendiam um golpe de estado de linha ortodoxa. Mais tarde, começaram a aparecer em Istambul pequenos grupos ou

\footnotetext{
${ }^{62}$ ZURCHER, Eric J. Turkey, a Modern History. New York, I.B. Tauris \& Co Ltd, 2005, p. 61-62.

${ }^{63}$ Idem, p. 53-54.

${ }^{64}$ ZURCHER, op. cit., p. 64.

${ }^{65}$ LEWIS, B. - The Emergence of Modern Turkey, op. cit. p. 131.
} 
sociedades secretas, nos moldes dos Irmãos Carbonari, autointitulados 'Jovens Otomanos'. Eram grupos de jovens intelectuais insatisfeitos e incluíam, em 1865, dois príncipes da casa de Osman: Murad e Abdul Hamid, embora este último, verificou-se depois, tivesse interesse em conhecer a organização para melhor combatê-la. O grupo incluía ainda um outro príncipe, da casa do Egito, Mustafá Fazil. Preterido na linha sucessória, Fazil tinha bons motivos para opor-se ao Sultão e ambicionava o posto de primeiro ministro do futuro estado.

A crise financeira do Império provocava grande fome na Anatólia e desconforto das províncias balcânicas não afetadas: revoltas dos cristãos, primeiro na Bósnia-Herzegovina, depois na Bulgária. A repressão da Porta à revolta búlgara, que deixou 15 mil cristãos mortos, causou uma onda de choque na Europa, que virtualmente ignorou os massacres cometidos em larga escala pelos cristãos contra muçulmanos na mesma ocasião. ${ }^{66}$

Em meio a tamanha crise, um grupo de políticos preparou um golpe de estado que depôs o Sultão Abdul Aziz em 30 de Maio de 1876. Assumiu o jovem Murat, já comprometido com o grupo dos Jovens Otomanos, liberais. Antes de subir ao trono, Murat promete promulgar a constituição. Em vez disso, editou apenas um decreto imperial, bastante vago. Em seguida, em 5 de junho, Abdul Aziz cometeu suicídio e um capitão do exército, por razões pessoais, matou vários ministros durante uma reunião do Gabinete. Esses acontecimentos contribuíram para que o estado mental de Murat deteriorasse a ponto de tornalo incapaz de conduzir o governo. O Gabinete decidiu por sua deposição, subindo ao trono o príncipe Hamit, agora Abdul Hamit $\mathrm{II}^{67}$, em 1 de setembro de 1876.

\section{5 -- Interesses imperialistas: as Grandes Potências Europeias}

Desde o século XVII, a ruína do Império Otomano já era esperada e desejada por todos os poderosos que buscavam reafirmar-se em suas políticas expansionistas: Rússia, Inglaterra e França mantinham os olhos muito atentos a cada movimento da Sublime Porta. E, cuidadosamente, verificavam os movimentos de seus pares, tentando conhecer suas intenções. Assim sendo, a Inglaterra não podia permitir que a Rússia se adiantasse em negociações com a Porta, pois isso traria vantagens ao Czar. Do mesmo modo, a França não desejava que Rússia e Inglaterra se entendessem nesse ponto e a deixassem de fora do botim final. Enfim, os 'aliados' associavam-se de tempos em tempos, para fins específicos, ou agiam sozinhos

\footnotetext{
${ }^{66}$ ZURCHER, op. cit., p. 72-73

67 Ver resumo da biografia de Abdul Hamid II no capítulo II.
} 
quando melhor lhes convinha, vigiando os próprios passos e os de seus concorrentes. $\mathrm{O}$ interesse final era o mesmo: um quinhão dos domínios otomanos, quanto maior, melhor.

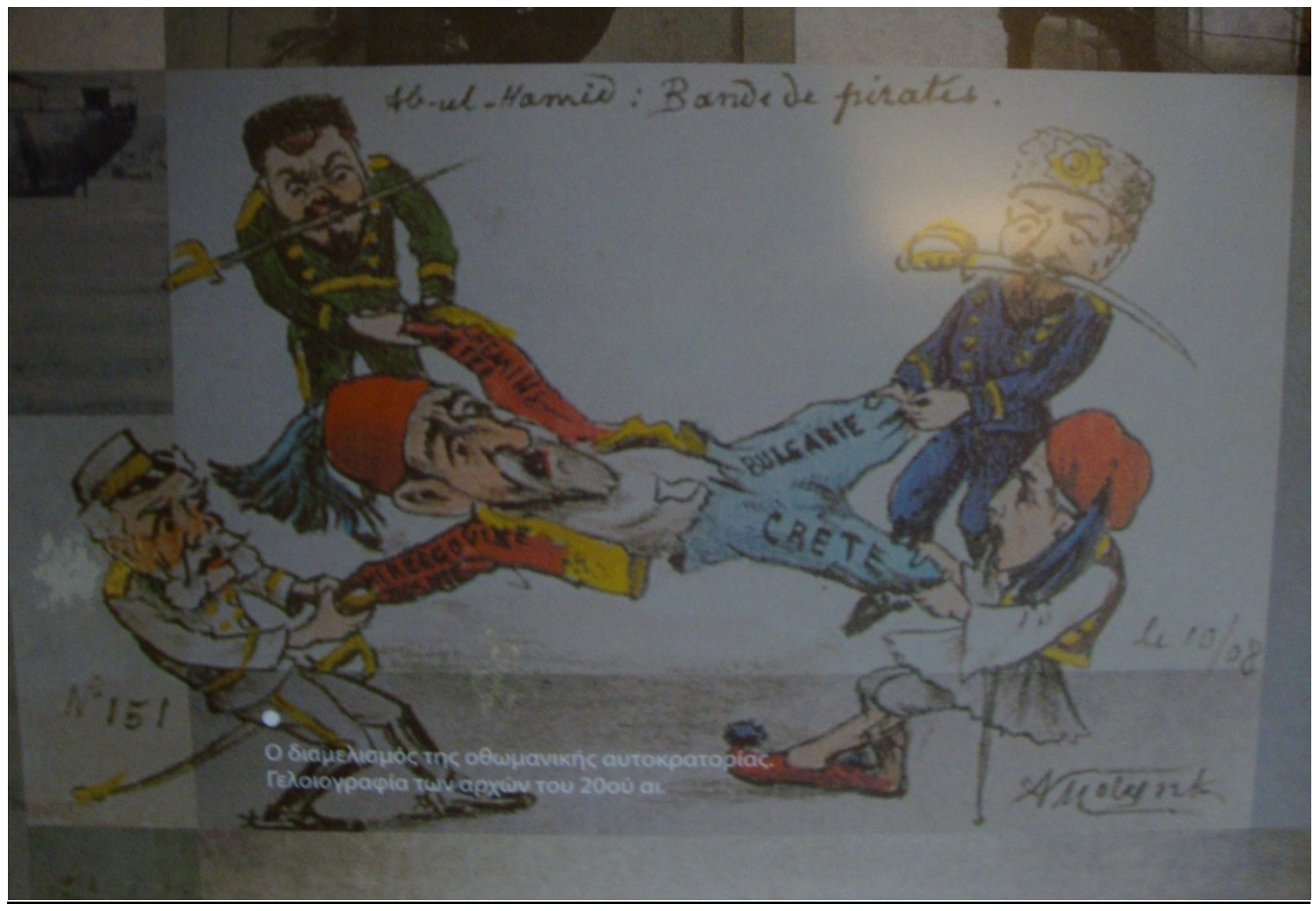

6 - "Abdul Hamid - Band de pirates" "O desmembramento do Império Otomano". Ilustração do Museu da Torre Branca, Thessalônica. Início do século XX”. Reproduzido por Ligia Sanchez, 2009.

A situação diplomática era difícil, pois para a divisão do Império Otomano, era necessário este ruísse, processo sempre acelerado pelos interessados na partilha. Porém, nenhum deles podia externar suas aspirações antes de receber os louros. Assim, as infindáveis disputas por território seguiam, permeadas por tratados de paz cujas determinações não eram levadas a termo. Em junho de 1807, foi assinado em Tilsit um acordo entre França e Rússia, para 'resolver ao menos parcialmente os problemas da Europa, pela divisão do Império Otomano, ${ }^{68}$. Em seguida, França e Inglaterra concluíram que a Rússia não podia assumir o controle de Istambul e dos estreitos, pois isso iria comprometer o equilíbrio de forças da Europa. Nesse momento, a Rússia estava em guerra com o Império Otomano e, pelos termos do tratado, os países signatários deveriam apoiar-se. Napoleão, entretanto, declarou que só

${ }^{68}$ SHAW, op. cit., p. 12. 
apoiaria a Rússia se o Império Otomano recebesse ajuda da Áustria. A Inglaterra, por sua vez, bloqueou os Dardanelos, para uma rápida finalização do conflito, forçando o Sultão a aceitar a paz, oferecendo para isso, a retirada de suas tropas do Egito e exigindo a recuperação dos privilégios Capitulares ${ }^{69}$ no Império.

O Czar seguiu com a guerra e sua assistência permitiu que a revolta sérvia inicialmente um protesto contra a tirania dos Janízaros em Belgrado - se transformasse em guerra de independência. Mas, quando Napoleão começou a sua campanha russa, em 1812, a Rússia foi obrigada a aceitar a paz nos termos do Sultão, perdendo vários territórios conquistados, apesar de sua superioridade bélica. No entanto, conquistou também o direito de manter seus privilégios Capitulares, como a Inglaterra. Estes privilégios permitiam intervenções na vida doméstica do Império, o que, enfim, também ajudou a minar as bases imperiais por outras vias.

A Revolução Grega é outro bom exemplo de maneira indireta encontrada pelos poderosos para minar o Império Otomano. A maior parte dos gregos estava satisfeita com sua situação, principalmente por sua prosperidade. A resistência à tourkokratia (domínio turco) era mantida subliminarmente pelos klefts (literalmente bandidos), cuja ação incomodava tanto turcos como gregos, mas no imaginário popular eram a única forma de genuína resistência aos desmandos otomanos, desde a queda de Constantinopla. Esses bandos de 'foras-da-lei', chamados de milícia pelos gregos, eram os únicos com alguma experiência militar. ${ }^{70}$

Durante o século XVIII, apesar da elite ortodoxa ter motivos para evitar a queda do Império e a consequente perda de seus inúmeros privilégios, a classe dos comerciantes cresceu entre os gregos e enriqueceu sobremaneira, fornecendo a base cultural e financeira para os 'proto-revolucionários'. Os trabalhos da Philiki Etairia ${ }^{71}$ seguiam, reunindo adeptos em toda a Europa Ocidental. Em 1821, uma tentativa de levante foi iniciada na Moldávia, e outra, quase ao mesmo tempo, no Peloponeso, aproveitando o momento em que o Sultão tentava disciplinar Ali Pasha, governador de Ioannina. Apesar do apoio de voluntários vindos da Europa e de organizações russas, as tropas irregulares dos gregos não conseguiriam enfrentar o exército imperial por muito tempo. A reação otomana, em geral foi de retaliação à

\footnotetext{
${ }^{69}$ As Capitulações eram uma série de privilégios legais e comerciais concedidos aos não-muçulmanos, em acordos com as grandes potências europeias, originalmente para encorajar o comércio internacional. O primeiro destes acordos foi fechado com o rei da França em 1535, e outros em 1604, 1673 e 1740. Em 1673, ficou acordado que a França seria a protetora de todos os católicos em suas relações com o Império.

${ }^{70}$ Link: http://www.greece.org/main/index.php?option=com_content\&view=article\&id=580\&Itemid=820

${ }^{71}$ Uma das muitas sociedades secretas surgidas nesse momento histórico na Europa, reunia jovens gregos e tinha como objetivo a luta pela independência da Grécia. Teve de fato papel determinante na luta, embora pouco sucesso nas ações diretas organizadas.
} 
população grega em todo o Império. Muitos gregos foram demitidos de postos importantes, ocorreram massacres como o de Chios, onde o patriarca foi torturado e enforcado ${ }^{72}$.

Miraculosamente mantendo algumas posições, as tropas gregas receberam um grave golpe quando o Sultão conseguiu o apoio de Muhamad Ali, do Egito, com a promessa de grande parte do espólio. Muhammad e seu filho Ibrahim Pasha reuniram tropas no Peloponeso e atacaram os insurgentes sem perdão, em 1825. Desesperados, os gregos procuraram apoio das três Potências ${ }^{73}$, oferecendo um ato de submissão à Inglaterra, que foi recusado. De todo modo, os grandes esperavam a oportunidade certa para tirar a vantagem certa da situação. $\mathrm{O}$ Protocolos de São Petersburgo colocaram a Rússia e a Inglaterra como mediadores do conflito. Pouco depois a França também foi incluída na 'interferência pacífica' que culminou com a Batalha de Navarino, em 20 de outubro de 1827, na qual as frotas dos três aliados destruíram 57 embarcações egípcias e otomanas, virtualmente esgotando os recursos navais do império, em apenas três horas.

\section{7 - O Estado Grego independente em 1829}

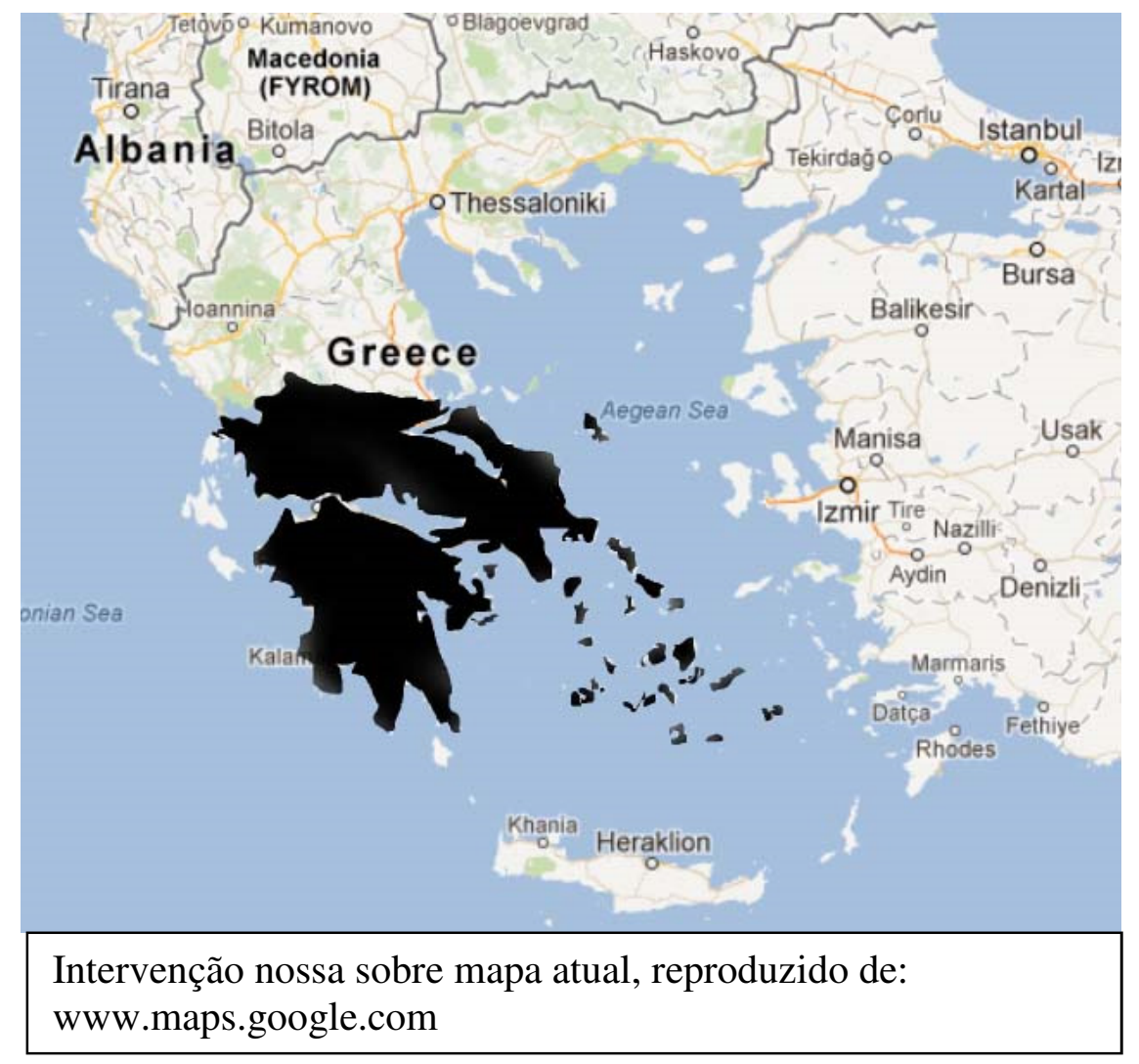

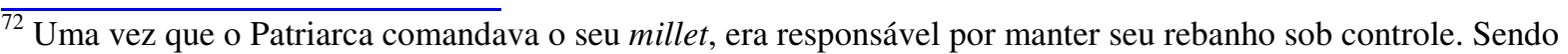
assim, quando haviam problemas desse tipo, a punição do patriarca era comum.

${ }^{73}$ A maioria das obras consultadas usa o epíteto "Potências" para designar a tríade Inglaterra, França e Rússia.
} 
Coincidentemente, ou não, o Czar declarou novamente guerra ao Sultão poucos meses mais tarde, deixando a Sublime Porta sem perspectivas senão aceitar a independência grega, para poder dispor de tropas contra a Rússia. Após longas negociações envolvendo os embaixadores dos três mediadores, chegou-se a um acordo quanto às fronteiras desse primeiro Estado grego livre: de Volos a Arta, o Peloponeso e algumas ilhas. Como parte do preço por essa mediação os poderosos determinaram que o novo país deveria ser uma monarquia e o rei escolhido entre as casas reais europeias ${ }^{74}$.

Se, por um lado, as potências europeias colocavam-se a serviço dos levantes nacionalistas, como nos Bálcãs, por outro, sua influência tornava ainda mais difícil qualquer atividade revolucionária, como na Armênia. Esta, desde o século XVIII, estava novamente dividida em Armênia turca e Armênia persa, mais tarde russa. Entretanto, não se pode falar em delimitações territoriais nesse caso. Existiam comunidades armênias dispersas por todo o Império Otomano, bem como na transcaucásia. Apesar de não terem perdido sua identidade cultural, mantida principalmente em torno da religião, os armênios estavam mais adaptados à sociedade otomana, cumpriam com seus deveres cívicos e utilizavam correntemente o idioma turco. O Millet armênio era, de fato, conhecido como o "millet fiel' 75 .

\section{8 - Composição etnológica da Ásia Menor e região, antes de 1910}

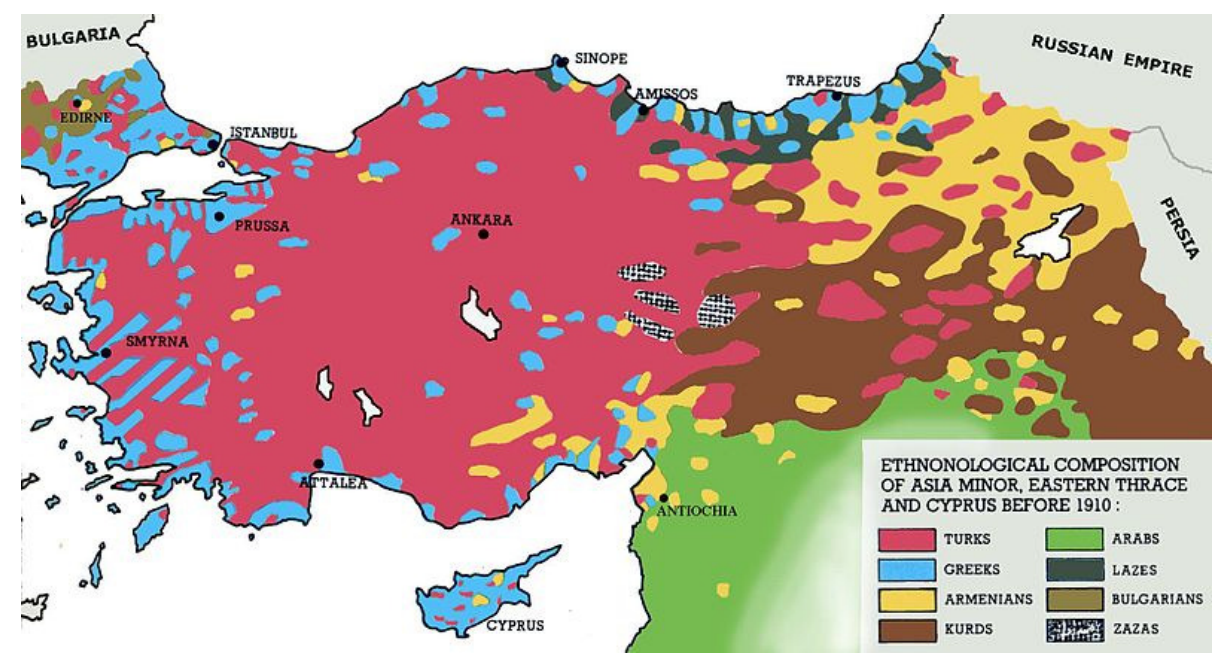

Reproduzido de:

http://upload.wikimedia.org/wikipedia/commons/7/75/AsiaMinor1910.jpg

\footnotetext{
${ }_{75}^{74}$ CLOGG, op. cit., p 43.

${ }^{75}$ Idem, p. 15 .
} 
A vida dos armênios radicados em Constantinopla e outros grandes centros era bastante confortável: atuavam como comerciantes, artesãos, banqueiros e, alguns, acumularam grandes fortunas. Mas os camponeses, grande maioria da população, sofriam com o descaso dos responsáveis públicos. Alimentavam um sonho nacionalista, mas a princípio sem nenhuma possibilidade de concretizar-se. Faltava base intelectual à consciência ideológica. Com o tempo, os filhos das famílias armênias abastadas de Constantinopla foram tomando contato com a educação ocidental, 'aguçando a consciência da anomalia de sua nação ser despojada de liberdade e soberania nacional' ${ }^{76}$

No início do século XIX, esta consciência deixou de ser uma tendência da elite intelectual e acabou se espalhando pelas massas, gerando um forte sentimento patriótico. A partir da conquista da Geórgia das mãos dos persas, a Rússia iniciou um movimento para anexação de territórios na transcaucásia, o que incluía grande parte da Armênia, com suas cidades mais importantes: Erevan, Etchmiadzin, o lago Van e o Karabagh, que atualmente estão dentro das fronteiras da República Armênia. A tutela russa era bem mais amena, o governo procurava desenvolver as regiões transcaucásias, situação que trazia benefícios aos camponeses, que se sentiam mais protegidos e menos espoliados. Do lado turco, entretanto, o povo armênio enfrentava os desmandos dos chefes locais e das tribos curdas. E, durante as invasões das tropas russas aos domínios otomanos nessa região, os armênios 'russos' engajados no exército reuniam admiradores entre os armênios 'turcos'. Alguns destes, inclusive, prestavam serviços clandestinos ao invasor.

A independência dos países balcânicos inspirou novo alento à esperança armênia de conquistar sua própria liberdade, mas a maioria dos líderes intelectuais preferia que a estratégia se fizesse por via política. Um importante impacto das Tanzimat foi a abertura do Império, não apenas para a penetração econômica europeia, mas para os missionários ocidentais e suas escolas. Isso complementou o renascimento cultural armênio, quando um movimento literário 'proto-nacional' começou a unir as comunidades armênias. ${ }^{77}$ Um tratado de paz russo-turco, firmado em março de 1878 em San Estefano incluía uma cláusula de suma importância, o famoso artigo 16, que estipulava "que a Sublime Porta se compromete a executar reformas e melhoramentos em benefício das províncias habitadas pelos armênios e

\footnotetext{
${ }^{76}$ SAPSESIAN, op. cit., p.88

${ }^{77}$ BLOXHAM, Donald. The Great Game of Genocide - Imperialism, Nationalism and the Destruction of the Ottoman Armenians. New York, Oxford University Press, 2005, p. 43.
} 
garantir sua segurança". ${ }^{78}$ Ao cumprimento dessas exigências estava condicionada a retirada das tropas russas da Anatólia.

O mesmo tratado, entretanto, determinava grandes concessões territoriais à Rússia. Essa parte do tratado suscitou a desconfiança britânica, que conseguiu convocar um congresso internacional poucos meses depois, para reexaminar essa questão. Em Berlim, em junho de 1878, a pequena delegação armênia viu suas expectativas caírem por terra. Dias antes da abertura do congresso, os ingleses já haviam firmado um acordo com o Sultão em Chipre, segundo o qual, os britânicos defenderiam os interesses da Sublime Porta em Berlim, em troca da concessão da ilha de Chipre para os britânicos. Ao tomarem conhecimento desse prévio acordo, os delegados em Berlim quase dissolveram o congresso. Retomados os trabalhos, ficou resolvida a imediata retirada das tropas russas, e, só então, o sultão iria efetuar as melhorias, que obviamente nunca aconteceram.

Desse episódio ficou uma parábola criada por Khrimian, o líder armênio presente no congresso: "aqueles que tinham longas colheres de metal (alusão aos búlgaros, romenos, sérvios, gregos, cujo anseio por independência contava com o apoio armado das potências) conseguiram alcançar o panelão e saciar-se do apetitoso herissé. Ora, a delegação armênia tinha apenas colher de papel (uma vaga promessa num documento oficioso) e, com colher de papel, não se come herissé..." 79

De acordo com Sapsezian, essa decepção política foi o que levou os armênios à luta armada e em contrapartida, a retaliação da Sublime Porta. A partir do momento em que os armênios se levantaram e ousaram exigir direitos, tornaram-se insubmissos aos olhos do sultão.

"Ninguém mais podia duvidar. A paciência e a resignação só levavam a becos sem saída. A única alternativa era revidar. O sentimento de revolta que há tempos germinava na alma de alguns pioneiros revolucionários começou a alastrar-se pela população. (...) jovens e idosos, homens e mulheres, todos sentiam que o momento era chegado para agir, com determinação e destemor, a fim de sacudir o jugo insuportável que há séculos oprimia a nação." 80

\footnotetext{
${ }^{78}$ Idem, p. 103.

${ }^{79}$ BLOXHAM, op. cit., p. 125.

${ }^{80}$ SAPSEZIAN, p. 129.
} 


\section{II - ANOS SELVAGENS: 1876 A 1923}

\section{1 - Abdul Hamid II - "Sultão Vermelho"}

A ascensão de Abdul Hamid II ao trono otomano marca a transição entre a tolerância e a aversão. A partir daí, embora de modo dissimulado no início de seu governo, as políticas estatais com relação às minorias se transformaram para sempre. O que até então era um esforço para igualar e assimilar, se transformou em uma luta selvagem para diferenciar, separar e eliminar. Sobre este item, também há divergências de opiniões entre os diversos autores que escreveram e ampliaram novas "versões da história".

\section{9 - Sultão Abdul Hamid II}

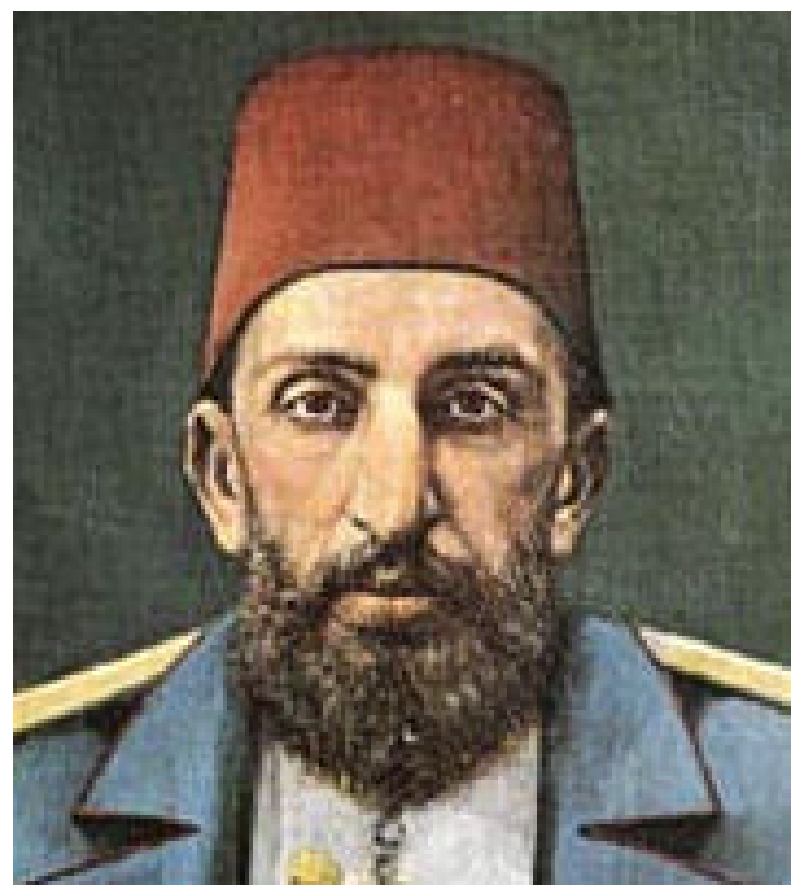

Fotografia reproduzida de http://www.globalsecurity.org/military/world/europe/otsultan-abdul-hamid-ii.htm

Trigésimo quarto Sultão Otomano, filho de Abdul Mecit I, Abdul Hamid II chegou ao trono após a deposição de seu irmão Murad V, cujo curto e celebrado reinado não pode continuar por conta de uma enfermidade mental. Murad, assim como Hamid, havia 
participado da sociedade dos Jovens Otomanos ${ }^{81}$, o movimento reformador que culminou com as Tanzimat.

A ascensão de Murad seguiu-se à deposição de Abdul Aziz por seus próprios ministros, em 30 de Maio de 1876, quando Murad subiu ao trono após comprometer-se em continuar e ampliar as reformas e promulgar a Constituição. Entretanto, limitou-se a editar alguns decretos de pouco alcance. O suicídio de Abdul Aziz, cinco dias após sua deposição e o assassinato de alguns ministros por um jovem oficial do exército, levaram Murad V a um colapso mental ${ }^{82}$. Em pouco tempo, os ministros da Sublime Porta perceberam que seria impossível a Murad conduzir os negócios administrativos do Império Otomano e optaram por uma nova deposição.

Assim, em 31 de Agosto de 1876, subiu ao trono aquele que seria o último sultão otomano relevante. Antes de coroá-lo, os ministros estiveram no harém onde este vivia e lhe esclareceram que somente seria sultão se promulgasse a constituição otomana, longamente esperada. Promessa feita, cabeça coroada. A primeira Constituição Otomana foi de fato promulgada em 23 de dezembro de 1876, baseada na Constituição Belga de 1831. Este ato serviu muito mais para evitar uma intervenção estrangeira após o choque que percorreu a Europa com a supressão brutal da revolta na Bulgária, ${ }^{83}$ do que para satisfazer o ego de ministros reformistas. De qualquer forma, a promessa foi cumprida. Por receio de ter a mesma sorte dos seus predecessores, Abdul Hamid II se preocupou em desenvolver as comunicações no Império, principalmente a rede telegráfica e uma inteligência secreta, responsável por enviar-lhe quilométricos relatórios sobre toda a atividade "suspeita" desenvolvida dentro de seus domínios. Muitos intelectuais que haviam retornado de Paris após a promulgação da constituição, na certa esperando dias melhores, foram novamente cassados e enviados ao exílio devido à severa censura promovida pelo sultão. Uma vez que a Constituição em vigor tornava desnecessária qualquer outra reforma que visasse melhoria das condições de vida das minorias, pelo menos do ponto de visto otomano, todas as demais propostas foram recusadas. $^{84}$

Após a desastrosa guerra com a Rússia (1877-78), Abdul Hamid II assinou o Tratado de San Estefano, com graves perdas como, por exemplo, a Bulgária que se tornava autônoma, a independência da Romênia e grandes territórios perdidos para Sérvia, Montenegro e para a

\footnotetext{
${ }^{81}$ Ittifak-i Hamiyet (Aliança de Patriotismo), sociedade secreta criada em 1865 por Namik Kemal que mais tarde abrangeria células em todo o império e em vários países europeus. O grupo de Paris era chamado de Jeune Turcs (jovens otomanos).

${ }^{82}$ ZURCHER, Eric J. Turkey, a Modern History. New York, I.B. Tauris \& Co Ltd., 2005, p. 73.

${ }^{83}$ Fonte de internet: http://www.britannica.com/EBchecked/topic/931/Abdulhamid-II

${ }^{84}$ ZURCHER, op. cit., p. 74.
} 
Rússia, além de reformas a serem feitas na Armênia. San Estefano provocou pânico entre as demais potencias europeias, que se apressaram a exigir uma nova reunião, em Berlim, para “equilibrar as forças", sem, é claro, levar em conta a opinião dos povos balcânicos. ${ }^{85} \mathrm{O}$ novo tratado assinado em junho de 1878 não trouxe mudanças significativas para o Sultão, cujos territórios perdidos não foram recuperados, mas proporcionou melhor distribuição desses "prêmios de guerra" entre os demais. O Sultão não teve outra escolha senão assinar o tratado, mas pelo menos nos assuntos domésticos sua vontade prevaleceu: Abdul Hamid II fechou o congresso em fevereiro de 1878 e retirou de vigor a constituição. Governou sozinho pelos trinta anos seguintes. A descrição de seu reinado é um bom exemplo de quanto divergem as opiniões a respeito dessa figura.

Os europeus do século XIX o viam como um tirano sanguinário e reacionário. A sangrenta repressão aos Armênios na década de 1890 foi fundamental para a formação dessa imagem. Os historiadores da república turca também o vêem como um reacionário que freou o desenvolvimento do império por uma geração. Entretanto, historiadores modernos da Turquia, desde 1960, citam a ampliação da rede ferroviária e de telégrafos e a duplicação do número de escolas e estudantes como exemplo de como seu governo foi uma continuação, ou até uma culminação, da era das Tanzimat e dos benefícios levados ao império e sua população. $^{86}$

Segundo Zurcher, Abdul Hamid era contra o liberalismo, o nacionalismo e o constitucionalismo. Procurava vencer essas forças ressaltando o caráter islâmico e tradicional do seu reino ${ }^{87}$, sendo uma de suas mais conhecidas atitudes o incentivo ao movimento PanIslâmico. Como Sultão otomano, acumulava a função de Califa, o líder religioso do Islã. Com essa importante prerrogativa, seu apoio ao movimento era de grande peso. A intenção era unir os muçulmanos de todo o mundo (não apenas os otomanos), de tal forma que os nãomuçulmanos fossem forçados a aceitar um retorno ao antigo estado de submissão. ${ }^{88}$

Na verdade, o Pan-Islamismo de Abdul Hamid II se aplicava apenas aos sunitas, grupo muçulmano majoritário do império. Isso teria causado desconforto em alguns grupos curdos, questão resolvida com a indicação de líderes curdos a cargos estatais pelo Sultão, reduzindo, assim, a possibilidade de união entre os curdos contra seu governo. Em 1891, Abdul Hamid criou os regimentos Hamidiye (ou 'de Hamid') - tropas curdas de cavalaria - que se

\footnotetext{
${ }^{85}$ Idem, p. 75.

${ }^{86}$ ZURCHER, op. cit., p. 77.

${ }^{87}$ Idem, p. 80.

${ }^{88}$ BLOXHAM, op. cit., p. 46.
} 
reportavam diretamente a ele, ultrapassando o poder das autoridades locais. ${ }^{89}$ Esses regimentos foram instalados principalmente na região da Anatólia Oriental, onde vivia a maior parte dos armênios, representando assim um primeiro passo em direção ao combate aos cristãos no Império Otomano.

\subsection{1 - Primeiros massacres}

Como vimos anteriormente, os povos habitantes da Anatólia estiveram envolvidos em conflitos desde a Antiguidade. Os armênios estabelecidos nessa região sempre sofreram com as invasões de tribos nômades, curdos e circassianos principalmente, que exigiam inclusive pagamento em troca de proteção. A distância do poder central permitia a ascensão de autoridades locais, que geralmente acumulavam a interessante função de coletores de impostos. Os abusos de poder eram tão constantes que o patriarca armênio chegou a enviar à Sublime Porta relatórios que contabilizavam, em 20 anos de queixas, 73 ofensas durante a coleta de impostos, 154 casos de abuso de poder pelas autoridades locais e 249 casos de roubo, sequestro e proibição dos padres de fazer seu trabalho. ${ }^{90}$

Sem resposta do próprio governo, as comunidades armênias voltaram-se para aliados externos. De acordo com os termos do Tratado de Berlim (1878), as potências europeias tinham o direito, ou mais ainda, o dever de exigir do Sultão as reformas necessárias para melhoria das condições de vida dessas comunidades. O principal resultado dos apelos à comunidade cristã internacional por parte dos armênios e da consequente pressão das potencias, foi a formação de uma consciência anticristã cada vez mais forte por parte do Sultão e de muitas lideranças muçulmanas. A formação dos regimentos Hamidiye, segundo Akçam, tinha a intenção declarada de proteger as fronteiras com a Rússia, mas seu verdadeiro alvo eram os armênios. A seguinte frase é atribuída a Abdul Hamid, em conversa com o visitante húngaro Armenius Vambery, sobre o uso das tropas Hamidieh:

"vou te dizer, eu vou controlar logo esses armênios. Vou dar a eles um 'tapa nas orelhas' que vai deixá-los espertos e fazê-los desistir de suas ambições revolucionárias". ${ }^{91}$

O mesmo Tratado de Berlim havia deixado os intelectuais armênios com a certeza de que somente a luta armada poderia resolver sua situação, como citado anteriormente, embora a grande maioria dos líderes político-religiosos preferisse uma solução diplomática.

\footnotetext{
${ }^{89}$ Idem, p. 47.

${ }^{90}$ AKÇAM, op. cit., p. 36.

${ }^{91}$ HASLIP, Joan. The sultan: the life of Abdulhamid. New York, 1973, apud AKÇAM, op. cit., p. 40.
} 
Uma das primeiras medidas tomadas pelo Sultão foi a redivisão da Anatólia em seis províncias ou vilaiettes, cada qual com um governador indicado pela Porta: Sivas, Erzerum, Kharput, Bitlis, Diarbekir e Van. De acordo com o historiador Akçam, a redivisão geográfica teria sido pensada para falsear a densidade demográfica dos distritos e mascarar a maioria armênia. ${ }^{92}$ Guenter Lewy também considera que o novo desenho das fronteiras teria ajudado a diminuir o número de armênios nessas províncias, juntamente com as emigrações, conversões e o influxo de muhajirs ${ }^{93}$ dos Bálcãs e do Cáucaso ${ }^{94}$. Na sua visão,porém, estes fatos não teriam sido produtos de um projeto prévio de perseguição. Na memória étnica turca, o sofrimento e a experiência de relocação desse período é conhecida como sökümü, o desastre. $\mathrm{O}$ governo ofereceu incentivos para muitos muhajirs estabelecerem-se ao longo das linhas férreas e a política de assentar esses refugiados em terras armênias parece ter se tornado sistemática, pressionando ainda mais a questão agrária e aumentando a insegurança dos armênios quanto à sua vida e propriedade. ${ }^{95}$

A rápida deterioração da situação dos armênios, principalmente em termos de segurança, acelerou o processo de conscientização nacionalista armênia e as ideias revolucionárias disseminaram-se em várias cidades. Os missionários estrangeiros teriam contribuído para a radicalização do processo. ${ }^{96}$ Seus relatórios enviados aos países de origem levaram ao mundo o conhecimento dos problemas desses colegas cristãos na Anatólia. As injustiças sofridas pela população cristã eram reais. Aos olhos das autoridades otomanas entretanto:

"interpretavam qualquer manifestação cultural ou resistência, individual ou local, como uma ato de rebelião nacional... os oficiais e intelectuais turcos passaram a ver os armênios como desobedientes, subversivos, elementos estranhos que se aliavam às potencias internacionais." 97

Do ponto de vista da Sublime Porta, os fiéis armênios estavam se tornando traidores. Transformavam-se em instrumentos para as potencias europeias alcançarem suas aspirações. Lord James Bryce, conhecido como protetor da causa armênia, apontou, em 1896, logo após a onda de massacres de armênios que:

\footnotetext{
${ }^{92}$ AKÇAM, op. cit., p. 41.

${ }^{93}$ Muhajirs são os refugiados muçulmanos vindos da Russia ou dos Bálcãs após a perda de territórios.

${ }^{94}$ LEWY, Guenter. The Armenian Massacres in Ottoman Turkey. Utah, University of Utah Press, 2005, p. 3.

95 ASTOURIAN, “Genocidal Process”, 61-2, 66-7, apud BLOXHAM, op. cit., p. 47.

${ }^{96}$ LEWY, op. cit., p.6.

${ }^{97}$ SUNY, Ronald G, "Empire and Nation: Armenians Turks and the End of the Ottoman Empire", Armenian Forum I, $n^{\circ} 2$ (Summer 1998):33, apud LEWY, p. 7.
} 
"Se não tivesse havido um Congresso de Berlim, nem uma Convenção AngloTurca, os armênios sem dúvida continuariam a ser oprimidos, como foram oprimidos por séculos. Mas teriam evitado a tempestade de fogo, fome e massacre que se abateu sobre eles em 1895... Antes do Tratado de Berlim, o sultão não nutria especial inimizade pelos armênios, nem a nação armênia tinha aspirações políticas. Foi a sugestão feita ali (em Berlim), de protegê-los, que os marcou como suspeitos e odiados. (...) A Convenção Anglo-Turca os ensinou a olhar para a Inglaterra e a interferência da Inglaterra enraiveceu os turcos 98

Até mesmo os autores armênios concordam que o nacionalismo armênio levou à criação de partidos com objetivos separatistas. A primeira, segundo Sapsezian, nasceu em Van em 1885: o Partido Armenagan denunciava pela imprensa as arbitrariedades sofridas e pregava a luta armada para defesa de suas famílias e bens. ${ }^{99} \mathrm{Em} 1887$, um grupo de estudantes armênios fundou o Partido Hunchakian em Geneva. ${ }^{100}$ Os "Hunchaks", como ficaram conhecidos, eram jovens influenciados pelo pensamento marxista, cujo objetivo era a restauração da Armênia histórica, que incluiria os armênios da Turquia, da Rússia e da Pérsia sob um governo socialista. ${ }^{101}$

A Federação Revolucionária Armênia (FRA), também conhecida pelo nome de Dashnaktsuthiun, ou Dashnaks, foi fundada em Tiflis, em 1890, por estudantes armênios russos. A princípio, reunia também os Hunchaks, mas estes logo se separaram e enfraqueceram. A FRA então se tornou a principal organização revolucionária armênia. Sua plataforma enfatizava a necessidade de emancipação política e econômica da Armênia turca.

"Para alcançar esses objetivos, 'por meio de revolução' os revolucionários deviam armar a população e lutar incessantemente contra o governo turco."102

Com relação aos partidos revolucionários armênios, Bloxham afirma que as queixas que pretendiam ressaltar eram todas muito reais e que, de modo geral, haviam organizações nacionalistas em desenvolvimento, praticamente em todas as populações cristãs do Império. Portanto, não seria de estranhar que ocorresse também entre os armênios. Entretanto, aos olhos do palácio, os armênios preocupavam pois compartilhavam com os projetos dos revolucionários búlgaros bem sucedidos e, também, porque a região que pretendiam "liberar"

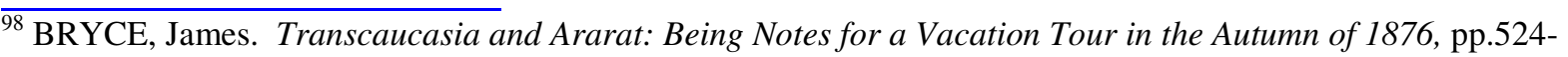
523, apud LEWY, p. 9.

${ }^{99}$ SAPSESIAN, op. cit., p. 129.

${ }^{100}$ Existem diferenças de grafia entre as obras de diferentes autores. Hunchakian também pode ser encontrado como Henchagian, ou Huntchaguian. Mantivemos a grafia mais encontrada nas obras consultadas.

${ }^{101}$ LEWY, op. cit., p. 11.

${ }^{102}$ LEWY, op. cit., p. 12.
} 
era justamente o coração do império. ${ }^{103}$ Entretanto, apesar de seus esforços e propaganda, os revolucionários armênios contavam com pouco apoio da população apolítica e menos ainda dos ricos armênios que viviam nas cidades. ${ }^{104}$ Chegavam mesmo a aterrorizar os próprios armênios, mas apesar dessas atividades crescentes, o regime Otomano não corria risco. $\mathrm{O}$ número de militantes era pequeno e eles lutavam entre si. ${ }^{105}$

Ainda assim, o governo e principalmente o Sultão, estava em estado de pânico. Suspeitava de qualquer movimento armênio e por alguns anos, cada levante repercutia em massacre. No verão de 1892, o governo britânico enviou uma nota à Sublime Porta, criticando severamente as medidas de repressão utilizadas pelo Sultão, o que o irritou ainda mais. O embaixador britânico enviou relatório a Londres em março de 1894:

"A inabilidade dos oficiais em distinguir entre crítica e sedição ativa; sua política de prisão indiscriminada para tentar encontrar algo que incrimine o prisioneiro; o recurso frequente de torturar para obter testemunho; o uso que alguns oficiais fazem das desordens para resolver inimizades pessoais ou extorquir dinheiro... ameaça criar rebeldes mais rápido do que a polícia pode pegá-los". ${ }^{106}$

Um inventário, ainda que resumido, dos principais massacres se presta para um "Raio X” da situação política vigente na época. Estes fatos geralmente são negligenciados pelas versões oficiais que procuram esvaziar este movimento e suas razões. O acúmulo destas ocorrências atesta que um conjunto de atos violentos preparava, desde 1894, o caminho para o "genocídio". Dentre os massacres cumpre citar:

\section{Sasun, 1894}

Parte da população armênia desta cidade protestava pela cobrança abusiva de impostos. Além do governo otomano, também as tribos curdas exigiam pagamento. Foi enviada a Istambul uma reclamação formal e o tribunal deu ganho de causa aos armênios, mas o governador local incitou a população contra eles ${ }^{107}$. Houve enfrentamentos nas ruas, com mortes em ambos os lados. A linha revolucionária dos Hunchaks apoiou a revolta armênia e a luta nas ruas tomou grandes proporções. A situação foi reportada ao Sultão, que enviou tropas

\footnotetext{
${ }^{103}$ BLOXHAM, op. cit., p. 49-50.

104 “Os revolucionários não apenas sofriam oposição da grande maioria da população e da liderança eclesiástica, como de fato eram um segmento muito pequeno daquela população." DADRIAN, Warrant for Genocide, p. 69, apud LEWY, op. cit., p. 14.

${ }^{105}$ LEWY, op. cit., p. 15.

${ }^{106}$ SIMSIR, British Documents on Ottoman Armenians, vol 3, p. 335, apud LEWY, op. cit., p. 15.

${ }^{107}$ SATOGLU Mithat, apud AKÇAM, op. cit. p. 41.
} 
para conter o levante. De acordo com as fontes turcas citadas por Akçam, as tropas se comportaram com selvageria contra os armênios e muitos foram massacrados. Hovanisian afirma que houve uma negociação e uma promessa de anistia desde que os armênios depusessem as armas e se rendessem. Ainda assim, grande número de habitantes foi morto, sem distinção de idade ou sexo. ${ }^{108}$

Novas pressões das potências levaram o Sultão a enviar comissários ao local para investigar. Enquanto isso, Abdul Hamid apelou à Alemanha por se sentir pressionado, mas não obtendo o retorno desejado, viu-se forçado a atender a vontade das potências: foi definido um novo plano de reformas, a princípio rejeitado pelo Sultão, que teria dito que 'esse assunto vai acabar em sangue ${ }^{, 109}$.

\section{Istambul, Setembro de 1895}

Como as reformas demoravam e os incidentes de sempre seguiam acontecendo, organizações armênias da capital iniciaram uma marcha de protesto, em apoio as propostas de reforma encaminhadas pelas potências europeias. Deveriam entregar uma petição ao Grão Vizir em uma passeata pacífica. De acordo com Sapsezian,

“(...) alguns espíritos se inflamaram e seus brados de 'liberdade ou morte' precipitaram a intervenção das forças policiais. Durante os enfrentamentos que se seguiram, um jovem manifestante, sentindo-se ameaçado, sacou uma arma em desespero e abateu o policial que investia contra ele. O tiroteio imediato foi implacável e dezenas de estudantes tombaram sem vida". ${ }^{110}$

Lewy, por sua vez, retrata o fato de outro modo:

"uma petição deveria ser entregue ao Grão Vizir, mas muitos dos quase quatro mil manifestantes, estavam armados com pistolas e facas. $\grave{A}$ alguns quilômetros dos escritórios do governo a polícias bloqueou a passeata, houve tiros, e na confusão que se seguiu, sessenta armênios e quinze gendarmes foram mortos e muitos mais feridos." 111

Esse foi o gatilho para uma trágica reação da população muçulmana de Istambul, que procurava armênios, inclusive em suas casas, para agredi-los, instigados pelo ódio do fanatismo. Os mortos contaram-se aos milhares. Este foi um episódio tão marcante que ganhou espaço junto às páginas literárias desta época. ${ }^{112}$ A versão estatal explicou a situação como uma tentativa de controlar a manifestação violenta dos armênios:

\footnotetext{
$\overline{108}$ HOVANNISIAN, Richard Armenia on the Road to Independence. 1918, p. 27, apud LEWY, op. cit., p. 16. ${ }^{109}$ SALT, Imperialism, p.88, apud AKÇAM, op. cit., p. 41.

${ }^{110}$ SAPSESIAN, op. cit., p. 135.

${ }^{111}$ LEWY, op. cit., p. 22.

${ }^{112} \mathrm{O}$ romance Loxandra, traduzido para várias línguas inclusive o espanhol, conta a história de uma matriarca grega que vive em Istambul no final do século XIX. Entre as peripécias da família, a autora dedica quase um
} 
"Em reação a essas revoltas, os Otomanos fizeram o que outros estados fizeram em tais circunstâncias, mandando forças armadas contra os rebeldes para restaurar a ordem e na maior parte, resolvendo rápido já que muito poucos armênios apoiavam os rebeldes ou as sociedades revolucionárias. Entretanto, para a imprensa e a opinião pública na Europa, agitada pelas histórias espalhadas pelos missionários e as sociedades revolucionárias, cada restauração da ordem dos otomanos era automaticamente considerada um 'massacre' de cristãos, enquanto milhares de muçulmanos assassinados são ignorados e as reclamações contra os muçulmanos automaticamente aceitas. Em muitos casos, os países europeus não apenas interferiram para impedir os otomanos de restaurar a ordem, mas também asseguraram a libertação de vários terroristas capturados, inclusive os envolvidos na revolta de Zeytun, na ocupação do Banco Otomano e na tentativa de assassinar o Sultão Abdul Hamid. Enquanto muitos foram expulsos do Império Otomano, não levou muito tempo para que conseguissem passaportes falsos e outros documentos e retornassem ao território otomano para continuar suas atividades terroristas, com a cooperação de patrocinadores europeus."

Após este massacre nas ruas de Istambul, sob o olhar dos embaixadores internacionais, as potências europeias forçaram o Sultão a aceitar o pacote de reformas estabelecido originalmente, incluindo a acomodação dos curdos e restrições à ação das tropas Hamidieh. Em 17 de outubro de 1895, o Sultão concordou em assinar um decreto que reunia a maior parte das reformas propostas. Recusou-se, no entanto, a divulgar o texto na integra, argumentando que a publicação iria inflamar seus súditos muçulmanos. O resultado dessa negociação incitou outras explosões de violência em várias cidades da Anatólia. ${ }^{114}$

Registram-se mortes nas cidades de Zeytun, Trabizonda, Erzerum, Bitlis, Van, Harput, Diyarbakir, Sivas e Çukurova, embora não comprovadamente relacionadas às ordens imperiais. No entanto, parece uma grande coincidência que os massacres tenham acontecido logo após o Sultão ter oficialmente concordado em efetivar as reformas ${ }^{115}$.

De acordo com o Consul Graves, o massacre (de Erzerum) aparentemente tinha sido planejado com cuidado, pois

\begin{abstract}
"antes de começar centenas de mulheres turcas se aglomeraram na cidade com sacolas, nas quais levaram o saque do bairro armênio. Os assassinatos de homens armênios nas ruas começaram com um toque de clarim e terminaram quatro ou cinco horas depois com outro toque, e o saque das lojas e casas armênias foi conduzido sistematicamente, as vidas de mulheres e crianças poupadas." 116
\end{abstract}

capítulo para narrar a longa noite do massacre dos armênios. IORDANIDOU, Maria, Loxandra, Barcelona, Ed Lúmen, 2000, p. 181-187.

113 Texto explicativo do site oficial do governo turco (consultado em 18/01/2013)

http://www.kultur.gov.tr/EN,32372/did-the-turks-engage-in-massacring-the-armenians-as-of-.html

${ }^{114}$ LEWY, op. cit., p. 23.

115 AKÇAM, op. cit., p. 42.

${ }^{116}$ GRAVES, Storm Centers of the Near East, p 157, apud LEWY, op. cit., p. 24. 


\section{Banco Otomano, agosto de 1896}

Em uma última tentativa de conseguir a atenção internacional, membros da organização Dashnak invadiram o Banco Otomano, ícone financeiro do Império. Armados com pistolas e dinamite, os revolucionários mantiveram centenas de funcionários como reféns. Segundo Lewy, aparentemente, essa ação já era conhecida tanto pela polícia turca quanto pela comunidade armênia, pois várias famílias armênias saíram da cidade na manhã do ataque. As autoridades turcas devem ter considerado que esse ataque iria desacreditar os rebeldes aos olhos da Europa, visto que o Banco Otomano era um empreendimento anglofrancês. Possivelmente, este seria o momento oportuno para dar uma lição nos armênios com uma retaliação brutal. ${ }^{117}$

As demandas dos rebeldes para a liberação dos reféns foram atendidas e todos saíram do país a salvo. Imediatamente após essa negociação, entretanto, ocorreu um novo massacre de armênios, de grandes proporções. Às seis da tarde do mesmo dia, bandos de muçulmanos, em sua maioria curdos e lazos, armados com barras de ferro e cassetetes, investiram contra armênios nas ruas. Os números variam entre oitenta mil (por um diplomata e historiador turco em 1895) e trezentos mil mortos (por dois membros da Academia de Ciências de Yerevan, em 1965). O Embaixador Alemão reportou uma estimativa de 60 a 80 mil. Era claro para os observadores, que essa ação não era uma reação espontânea, mas cuidadosamente preparada. Centenas de casas e lojas foram saqueadas e destruídas, muitos foram forçados a se converter, outros optaram por fugir e, ainda, a fome e as doenças também fizeram vítimas em seguida. ${ }^{118}$

Como se nota, há muita controvérsia, tanto no número de vítimas quanto na descrição do fato em si. É praticamente impossível comprovar a versão correta, dificultando a análise dos fatos que carecem de estatísticas. Ficamos no contexto do trauma, da dor e solidariedade aos armênios massacrados. Em uma visão geral, ainda que os revolucionários provocassem situações de conflito, na maioria das vezes percebe-se a intenção declarada de chamar a atenção das potências para os problemas armênios e exigir seu apoio, levando, contudo, à imediata e violenta resposta da Porta, evidência que o governo turco atualmente chama de "restaurar a ordem". $\mathrm{Na}$ verdade, esta foi uma forma de eliminar um grande número de armênios tomando como justificativa a "desordem" e a "segurança nacional". Porém, nada justifica, por exemplo, que os massacres tivessem hora marcada para começar e terminar, ao som do clarim, como foi relatado em diversas situações. Ao "restaurar a ordem", ocorriam

${ }^{117}$ LEWY, op. cit., p.25.

${ }^{118}$ Idem, p. 26. 
saques às propriedades armênias, um ato claramente sem conexão com uma intervenção policial "de rotina".

Ainda segundo Lewy, a intervenção europeia foi constante o suficiente para despertar a ira dos turcos, mas nunca efetiva o suficiente para proporcionar a real proteção aos armênios. Os refugiados muçulmanos vindos dos Bálcãs contavam histórias terríveis sobre os desmandos dos cristãos e como os muçulmanos haviam sido mortos. Após a guerra russoturca, mais de meio milhão de muçulmanos búlgaros entraram no Império e eram conhecidos por seu ódio anticristão. Alguns desses refugiados sabidamente participaram dos massacres de seus vizinhos e a grande massa se juntou, de corpo e alma, à pilhagem e ao assassinato, por motivos variados. Fanatismo religioso, ganância pelo saque e intolerância funcionaram como elementos mobilizantes em proporções variadas e em diferentes lugares, culminando com as matanças. $^{119}$

A responsabilidade das potências europeias será tratada mais adiante, mas fica evidente que as chamadas 'intervenções' eram, muito mais, fruto das próprias necessidades de afirmação de poder daquelas nações, inclusive perante seus pares, do que uma real intenção de "salvar" os cristãos do Império.

Após essa onda de massacres que durou até 1896, a situação se acomodou, de certa forma. Talvez porque o governo otomano tenha procurado não provocar os governos europeus ou, talvez, porque os armênios tenham evitado novos confrontos. Afinal, a função dos massacres, segundo Bloxham, foi avisar aos armênios e às potências europeias que não pressionassem por reformas. Segundo este mesmo autor, com a guerra greco-turca em Creta em 1897, o assunto "reformas" foi esquecido pela próxima década. ${ }^{120}$ A maior parte dos historiadores falha em descrever eventos no período compreendido entre o ataque ao Banco Otomano (1896) e a ascensão dos Jovens Turcos (1906). No entanto, Lewy relaciona vários ataques dos revolucionários Dashnaks a tribos curdas, principalmente na fronteira com a Rússia. Esses ataques, na sua opinião, alguns com sucesso, teriam repercutido muito pouco na Europa (talvez por essa razão não são citados na literatura), apesar de terem proporcionado aos armênios uma sensação de poder e capacidade para resolver seus problemas sem ajuda externa. $^{121}$

\footnotetext{
$\overline{119}$ BLISS, Turkish Cruelties upon the Armenian Christians, p. 557, apud LEWY, op. cit., p. 29.

${ }^{120}$ BLOXHAM, op. cit., p. 55.

${ }^{121}$ LEWY, op. cit., p. 31.
} 
O despótico reinado de Abdul Hamid oprimia não só os armênios e outros cristãos, mas também intelectuais e políticos que se opunham a ele. Com uma rede de espiões e informantes espalhada por todo o seu domínio, o Sultão controlava as pequenas organizações de oposição que despontavam pelo império. Jovens intelectuais foram presos e expulsos do país, por conta de suas tendências políticas "revolucionárias". Em geral, esses grupos reuniam-se secretamente tendo, assim sua circulação e alcance limitados.

\subsection{2 - Os Jovens Turcos}

Em 1889 surgiu um novo grupo, desta vez dentro da escola de medicina, disposto a fazer oposição a Abdul Hamid II. Este movimento cresceu rapidamente e, em pouco tempo, contava com células organizadas em várias cidades do país. Alguns membros da sociedade foram presos e exilados em diversos destinos, como Cairo e Atenas, após o que procuravam reunir-se em Paris, para onde haviam fugido alguns dos antigos organizadores. Ahmet $\operatorname{Riza}^{122}$ foi contatado pela célula e em 1895 aceitou liderar a organização na Europa ${ }^{123}$. Ele publicava em Paris um periódico chamado Meşveret ou 'consulta', cujos pensadores se reuniam sob nome de Intizam ve Terakki (Ordem e Progresso), de linha positivista. O grupo de Istambul, Ittihad-i Osmanli (União Otomana) trocou seu nome para Ittihad ve Terakki (União e Progresso) ao identificar-se com a linha de Riza. ${ }^{124}$

Quando o Meşveret começou a circular em Istambul, o número de adeptos cresceu rapidamente, chamando a atenção das autoridades para as atividades do grupo. Seus membros foram responsáveis pelo golpe de 1896, que deveria depor o Sultão, mas foi denunciado e seus líderes presos e deportados para províncias remotas do Império. ${ }^{125}$ Apesar do fracasso do golpe, o grupo agora conhecido como "Jovens Turcos" continuou a atuar em Istambul, embora sem muito fôlego.

As relações entre o governo e as minorias cristãs se deterioravam, mas o sultão não era impopular entre seus súditos, nem tinha motivos para ser. Sob seu governo, a população muçulmana cresceu de 20 para 27 milhões e a fome e as epidemias rarearam. ${ }^{126} \mathrm{Um}$ novo

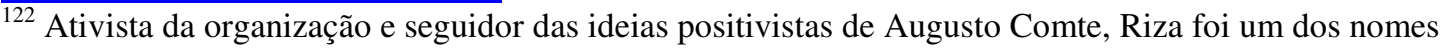
principais da organização em Paris, onde publicava o periódico Meşveret sobre a unificação da tradição otomana e islâmica. Após o golpe, teve vários cargos de importância no governo, foi ministro da educação e era nome cotado para Grão Vizir. Foi o presidente do primeiro parlamento otomano, na segunda era constitucional do império otomano.

${ }^{123}$ ZURCHER, op. cit., p. 86.

${ }^{124}$ LEWIS, The Emergence of Modern Turkey, op. cit., p. 198.

125 Idem, p. 199.

${ }^{126}$ ZURCHER, op. cit., p. 85.
} 
alento para os revolucionários foi a presença em Paris dos príncipes Damad Mahmud Celâleddin, neto por parte de mãe do sultão Mahmud II e sua esposa, irmã de Abdul Mecit, com os filhos Sabaheddin e Lûtfullah, que vieram integrar o grupo. Trouxeram força e prestígio aos "Jovens Turcos", ao mesmo tempo em que evidenciavam as diferenças internas que acabaram por dividir o movimento entre o nacionalismo turco de Ahmed Riza e o liberalismo otomano, de Sabaheddin. ${ }^{127}$ A questão que determinou a cisão de fato foi o interesse dos armênios integrantes do grupo, que, conscientes dos massacres de 1894-96, desejavam a intervenção das potências europeias como garantia das reformas do império. Os nacionalistas do Comitê para União e Progresso (CUP), entretanto, eram totalmente contrários a essa posição. ${ }^{128}$

A partir daí, a ideia da revolução chegou aos oficiais militares. Consta que uma das primeiras, se não a primeira dessas células militares, a 'Pátria e Sociedade Livre' foi criada em 1906, em Damasco e contava com Mustafá Kemal ${ }^{129}$ entre seus membros. Ele havia completado com distinção sua formação no Colégio de Oficiais e esperava ser alocado na unidade de treinamento de Thessalônica, sua cidade natal e também berço do movimento revolucionário que iria de fato mudar o país nos próximos anos. Entretanto, a diligente polícia secreta do Sultão descobriu um apartamento onde se reuniam alguns dos jovens politicamente engajados em Istambul, incluindo Kemal, que foi detido para averiguações junto com vários companheiros. Mantido em isolamento, ele descobriu que havia sido acusado de publicar jornais e liderar uma organização secreta, ações que seus colegas já haviam confessado. Sua prisão de alguns meses chegou ao fim tão repentinamente como começou e todos foram chamados de volta ao Quartel General e designados para seus postos em Edirne e Thessalônica, justamente onde queriam estar. Porém, a manifestação de júbilo dos jovens soldados foi interpretada como prova de conspiração e, sendo assim, acabaram enviados à Síria. $^{130}$

Em Thessalônica, a vida política borbulhava. Em setembro de 1906, Ismail Canbulat e Midhat Sukru [Breda] fundaram a 'Sociedade para a Liberdade Otomana' e o primeiro comitê reunia 10 homens, entre os quais Bursali Tahir, o diretor da Escola Militar de Thessalônica, assim como Talaat, o chefe dos correios e telégrafos, e outros oficiais do Terceiro

\footnotetext{
${ }^{127}$ LEWIS, The Emergence of Modern Turkey, op. cit., p. 203; ZURCHER, op. cit., p. 87.

${ }^{128}$ LEWIS, The Emergence of Modern Turkey, op. cit., p. 201-203.

${ }_{129}$ Mustafa Kemal, mais tarde chamado de Kemal Atatürk, "pai dos turcos", conhecido e respeitado como o fundador da República turca, em 1923. Kemal era membro dos "Jovens Turcos", mas não participou do governo central durante o governo do Comitê de União e Progresso (CUP). Essa ausência seria sua fortuna pouco tempo depois, como será explicado ao longo do texto.

${ }^{130}$ MANGO, Andrew, Atatürk, the Biography of the Founder of the Modern Turkey, New York, The Overlook Press, 2002, p. 55.
} 
Regimento. ${ }^{131}$ Em setembro de 1907, após um segundo congresso convocado por iniciativa armênia, no qual até mesmo o grupo de Riza teria aceitado a via da violência, o Terceiro Regimento, de Thessalônica, havia se juntado ao CUP. A essa altura, o exército de Abdul Hamid ganhava mal, tinha poucos recursos e alimentação ruim. Os "Jovens Turcos" mostravam-se preocupados com a inépcia real em defender seu império e com isso, ganharam muitos simpatizantes nas Forças Armadas. Alinhados com Riza, o grupo voltou a se chamar Ittihad ve Terakki Cemiyeti (Sociedade ou Comitê de União e Progresso - CUP) ${ }^{132}$

Aproveitando o descontentamento notório do exército de Abdul Hamid, o Tzar russo e o Rei Edward II da Inglaterra se reuniram para decidir a questão macedônia, forçando o estabelecimento de um governo estrangeiro na região, ato que deixaria o Sultão em situação de subalterno. A notícia desse encontro somou-se ao fato de que o movimento estava por ser descoberto pelos agentes do sultão e deu início à revolução dos Jovens Turcos, que preferiram agir antes que fosse tarde demais..

Nos primeiros meses de 1908, o CUP saiu das sombras apoiado pelo Terceiro e o Segundo regimentos, respectivamente de Thessalônica e Edirne, e exigiu do sultão a restituição da Constituição. Este tentou resistir, mas foi forçado a promulgar a Constituição em 23 de julho de 1908 e a reabrir o parlamento, dissolvido há 30 anos. Apesar de ter cedido à pressão dos revolucionários, Abdul Hamid II não se abateu completamente. Acionou a máquina de comunicação que havia criado em seu benefício, principalmente na Anatólia e outros lugares de difícil acesso, espalhando a sua própria versão dos fatos:

"por anos ele havia sido levado a pensar que o país não estava pronto para a Constituição, mas agora havia percebido que tais conselheiros eram traidores e que era a hora para isso". 133

Segundo Lewis, a "longa noite do despotismo hamidiano estava terminada, a aurora de liberdade chegara. A constituição estava novamente válida e haveriam eleições. Turcos e Armênios se abraçavam nas ruas. A era da liberdade e fraternidade havia chegado"134.

O segundo regime constitucional turco durou mais que o primeiro, mas também terminou em amargo fracasso e desapontamento. Os perigos e dificuldades, dentro e fora de casa, eram muitos e os defensores da constituição poucos, fracos e ineptos. Apesar de manter a Constituição e as eleições, o regime degenerou para um tipo de oligarquia militar dos “Jovens Turcos" que só terminou com a derrota do Império Otomano em 1918.

\footnotetext{
${ }^{131}$ LEWIS, op. cit., p. 205.

132 ZURCHER, op. cit., p. 90.

${ }^{133}$ Idem, p. 95.

${ }^{134}$ LEWIS, op. cit., p. 210.
} 
Y. H. Bayur, historiador turco, observou que

"poucos movimentos no mundo suscitaram tão grandes esperanças como a Revolução Constitucional Otomana; entretanto, do mesmo modo, poucos movimentos tiveram suas esperanças tão brutal e definitivamente desapontadas." 135

\section{2 - O governo do CUP}

Surpreendentemente, os jovens revolucionários não tomaram o poder, nem depuseram o sultão que manteve sua popularidade inabalada. Também porque na sociedade otomana, a idade e o tempo de serviço eram precondições para a autoridade e os "Jovens Turcos" não tinham nem uma nem a outra, de modo que preferiram manter as coisas como estavam e vigiar as ações do governo por trás das cenas. Esse modo de agir impediu que as aspirações verdadeiramente 'otomanistas' fossem levadas a cabo, pois apesar das primeiras eleições apontarem a vitória fácil dos Unionistas, os parlamentares não reconheciam a visão única do Partido. A lacuna de poder - mandava o Sultão, o Parlamento ou o exército? - permitiu um levante contrarrevolucionário no ano seguinte. Também pode-se especular que este momento, em particular, tenha sido escolhido por diversos governos estrangeiros para realizar suas conquistas de território em detrimento das terras da Sublime Porta, justamente por essa razão. Menos de 3 meses após o golpe, chegaram notícias desalentadoras das fronteiras: a Bulgária declarou sua independência em 5 de outubro e a Áustria anexou oficialmente a BósniaHerzegovina, em 6 de outubro de 1908. No mesmo dia, a Assembleia em Creta aprovou uma resolução formando um governo interino, em nome do Rei dos Helenos (Gregos). ${ }^{136}$

Em 9 abril de 1909, os contrarrevolucionários, que lutavam pela restauração do Islã e da Shari' ${ }^{137}$, conseguiram retomar o poder e passaram a perseguir os Unionistas, sendo que alguns tiveram que deixar o país. A reação do CUP foi imediata: em 15 de abril já tinham um 'Exército de Ação' formado a partir das tropas regulares do Terceiro Regimento, que incluía em seus quadros Sevket Pasha, Enver e Niyazi Bey ${ }^{138}$. Segundo Lewis, o comandante das

\footnotetext{
$\overline{135}$ BAYUR, Y.H., Türk Inkilabi Tarihi, apud LEWIS, B. The Emergence of Modern Turkey, op. cit., p. 210-211 ${ }^{136}$ Tratativas para a união de Creta à Grécia já aconteciam desde 1899, intermediadas pelas potencias europeias. A decisão da assembleia cretense em 6 de outubro de 1908 não foi oficialmente acatada pelo rei grego, por falta de apoio europeu. A união oficial aconteceu em 1913.

137 Shari'a, é a Lei Islâmica, o código moral muçulmano. Pode ser encontrada na literatura com diversas grafias: Charia, Sheriat, Syariat.

${ }^{138}$ ZURCHER, op. cit., p. 97.
} 
tropas era o próprio Kemal. ${ }^{139} \mathrm{O}$ 'Exército de Ação' marchou para Constantinopla e com a anuência dos parlamentares, ocupou a cidade em 24 de Abril, sem grandes confrontos, devolvendo o governo aos líderes do CUP. Sua primeira medida foi a instauração de cortes marciais que julgaram e condenaram os rebeldes. Ato contínuo, agora sim, reforçados politicamente, depuseram o Sultão, colocando em seu lugar o suave Mehmet V. ${ }^{140}$

A onda reacionária que expulsou temporariamente o CUP do palácio também teve repercussões no interior do Império. Em Adana, um novo massacre da população armênia começou em 14 de abril de 1909 e só foi 'resolvido' em 27 de abril. Existem inúmeras versões sobre os acontecimentos em Adana. Para dar uma ideia do quão complicado estava o "problema armênio" no Império Otomano nesse momento, citamos alguns relatos:

"Djemal não ficou em Istambul. Em 14 de Abril, um dia depois do motim na capital, sérios problemas intercomunais irromperam entre turcos muçulmanos e armênios em Adana, a principal cidade de Çurokova (Cilicia). Como em outros lugares do império, a ordem havia se deteriorado após a queda do antigo regime. As apreensões muçulmanas foram alimentadas por um prelado Armênio, Arcebispo Moushegh, que apressou seu povo a comprar armas. Pogroms antiarmênios se espalharam em Adana e nas imediações. Cerca de vinte mil armênios e dois mil muçulmanos foram mortos e grande parte da cidade foi queimada. Djemal foi enviado à cidade como governador, para restaurar a ordem. Ele fez isso com mão firme. Quarenta e sete muçulmanos, incluindo um mufti, e um armênio foram enforcados". ${ }^{141}$

"A contra revolução não se espalhou de fato pelas províncias. Houve um incidente entretanto, que pode ser ligado a isso. Na província de Adana, um grupo de apoiadores do antigo regime aproveitou a oportunidade da quebra de poder central para atacar os representantes dos unionistas. $O$ protesto se transformou em pogrom e um grande número (possivelmente 20.000) de cidadãos armênios foram massacrados. Uma comissão parlamentar de inquérito foi enviada a Adana e 124 muçulmanos e 7 armênios foram executados." 142

"As novas relações de amizade entre os Dashnaks e o CUP sobreviveram até mesmo a um novo massacre em Adana e outras partes da Cilicia, que aconteceram no início do contragolpe conservativo em Abril de 1909. Por algum tempo, parece, o líder da comunidade armênia de Adana, Arcebispo Musheg, havia apressado seu povo a adquirir armas, espalhado ideias chauvinistas e se envolvido no que os muçulmanos percebiam como um comportamento de desprezo em relação aos muçulmanos. Os armênios da Cilicia, (...) haviam declarado sua liberdade e igualdade com os muçulmanos em termos desnecessariamente ofensivos. Figuras religiosas muçulmanas, em contrapartida, se opuseram à recém proclamada ideia de igualdade para todas as religiões e incitaram a multidão contra os armênios. A primeira onda de massacres acorreu em 14 de abril, poucas horas depois de o grupo de reacionários ter tomado o poder em Constantinopla. Tropas enviadas para restaurar a ordem participaram dos saques e assassinatos. Depois que navios de guerra europeus entraram no porto de Mersina e no dia em que os Jovens Turcos recuperaram Constantinopla uma segunda onda de massacres se seguiu. Junto

${ }^{139}$ LEWIS, op. cit., p. 216.

${ }^{140}$ ZURCHER, op. cit., p 98.

${ }^{141}$ MANGO, op. cit., p. 90

142 ZURCHER, op. cit., p. 99 
com uma violenta explosão, resultaram em cerca de vinte mil mortos, a maioria armênios. $" 143$

"O movimento reacionário entretanto não estava restrito a Istambul. Com suspeita simultaneidade, uma onda de choques se espalhou pela Anatólia. Particularmente ruins foram os acontecimentos em Adana, que culminaram com o massacre de milhares de Armênios. Enquanto a Europa estava chocada com a brutalidade dos turcos, a opinião dos muçulmanos era de assombro com a insolência dos armênios e a hipocrisia da Europa Cristã." ${ }^{144}$

"Durante os primeiros anos do governo dos Jovens Turcos, os armênios sofreram mais uma onda de ataques. No distrito de Cilicia, os armênios se tornaram especialmente destacados ao expressar suas esperanças por reformas, e em resposta algo como quinze ou vinte mi armênios foram mortos em pogroms em 1909, que foram atribuídos a agentes de Abdul Hamid, durante o contragolpe do Sultão contra os Jovens Turcos. Como parte do pogrom, cinquenta igrejas foram destruídas, junto com cinco mil casas e lojas armênias. O governo dos Jovens Turcos, mais tarde, se desculpou pelos massacres e destruição de propriedades; entretanto, à luz do eventos ainda por vir, é possível que os elementos nacionalistas dos Jovens Turcos estivessem de acordo com o que aconteceu, principalmente porque alguns dos soldados enviados para suprimir o massacre parecem ter participado deles." 145

"O massacre de Adana foi a segunda série de massacres de armênios a ocorrer no império otomano. As atrocidades cometidas na província de Adana em Abril de 1909 coincidiram com a contrarrevolução preparada pelos apoiadores de Abdul Hamid (...) Os distúrbios foram mais severos na cidade de Adana onde 4.437 casas de armênios foram queimadas, resultando na destruição de quase metade da cidade e levando alguns a descrever o inferno como "holocausto". As revoltas eclodiram em toda a cidade e estimadamente trinta mil armênios foram mortos. Enquanto as tentativas de resistência em Adana se provaram inúteis e os armênios nas pequenas vilas ao redor foram brutalmente assassinados, duas cidades habitadas por armênios organizaram uma defesa bem sucedida - Hadjin resistiu ao cerco e os dez mil armênios de Dortyol seguraram sete mil turcos que haviam cercado a cidade.

A intensidade dos massacres levou o governo a abrir uma investigação, mas o fracasso do processo desanimou as expectativas armênias de reformas liberais pelo novo regime. Os elementos reacionários do império otomano eram suspeitos de instigar os massacres para desacreditar o CUP, mas os Jovens Turcos também estavam implicados. Ao massacres de Adana expuseram a dupla composição do Movimento dos Jovens Turcos, que consistia tanto de elementos liberais quanto de radicais nacionalistas. (...) Para os Jovens Turcos, os massacres de Adana se provaram um ensaio para aferir a profundidade da animosidade turca no império otomano contra as minorias cristãs e para testar sua capacidade de comandar essas forças para fins políticos" ${ }^{\prime 16}$

"Nas duas fases do massacre, as mortes começaram em Adana e se espalharam pela província. $O$ mais perturbador para os armênios foi a participação das autoridades

\footnotetext{
${ }^{143}$ LEWY, op. cit., p. 33

${ }^{144}$ Idem, p. 216

${ }^{145}$ MILLER, Donald. E; Miller, Lourna T. Survivors - An Oral History of the Armenian Genocide. Berkeley, University of California Press, 1999, p. 52.

146 ADALIAN, Rouben Paul, no site: http://www.armenian-genocide.org/adana.html
} 
locais, da polícia e dos militares nesses massacres. O centro do CUP em Istambul não pode ser diretamente responsabilizado, já que durante a maior parte do tempo estavam ocupados com o contragolpe. Mais ainda, vários membros do CUP e armênios trabalharam juntos para proteger a constituição. Entretanto, as ordens vindas do ministério do interior em Adana no início dos massacres mostravam uma preocupação maior em prevenir intervenção externa que em proteger os armênios. Finalmente, muitos soldados leais ao CUP foram enviados a Cilicia após o 27 de abril e tomaram parte nos massacres por sua vez, apesar de não haver prova de que agiam sob ordem superior. Após esses acontecimentos, não apenas não houve uma tentativa substancial de punir os culpados ou restaurar as propriedades armênias como alguns dos oficiais mandantes foram mantidos em seus postos e a comissão de inquérito estabelecida procurou culpar os revolucionários armênios. Não encontraram evidencias para essa acusação. ${ }^{147}$

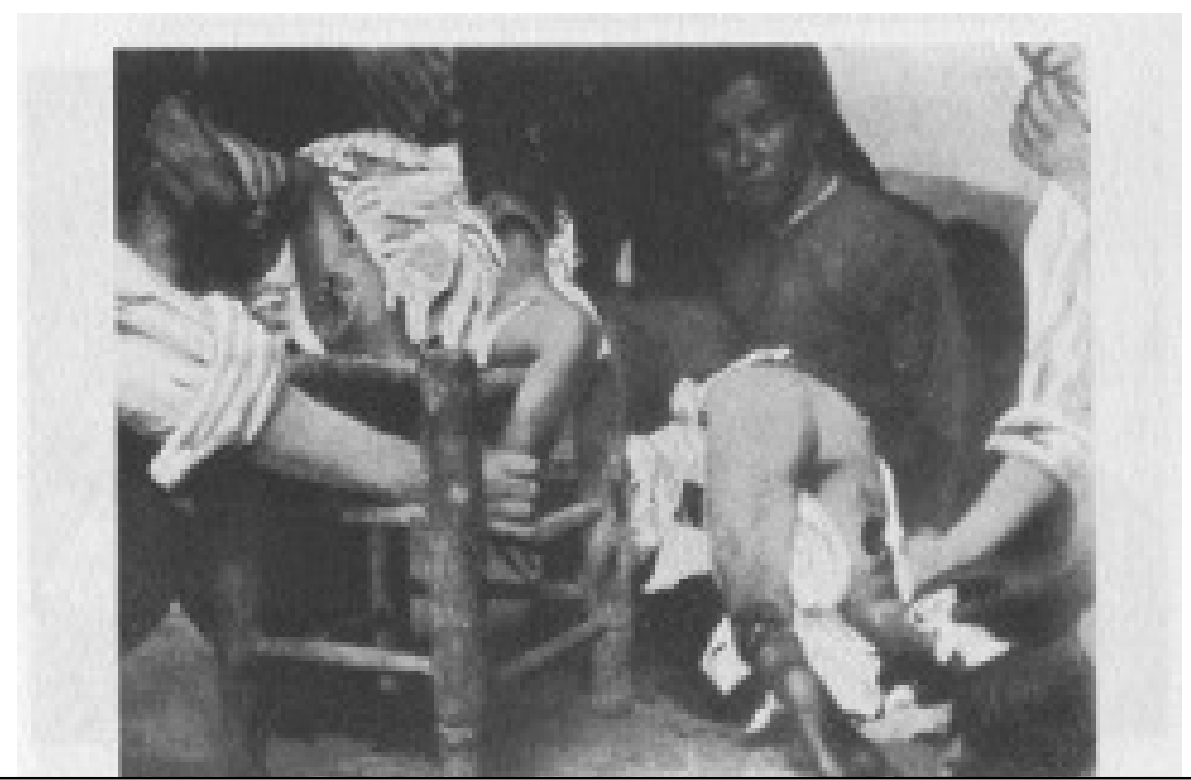

10 - "Massacres em Adana, Abril 1909:crianças armênias cuja carne foi decepada com tesouras de tosquia e cujos tendões dos joelhos foram cortados. De ERNST, Jäckh, The Rising Halfmoon. Berlin-Schöneberg, 1911. (Cortesia de Informations-undDokumentationszentrun Armenien, Berlin)

Como se nota, há divergências nos números, bem como nas razões para o início do massacre, entre os diversos autores. Mas os fatos, em resumo, são os mesmos: morreram muito mais armênios que turcos, as igrejas, casas e lojas armênias foram queimadas e parece coerente afirmar que líderes locais incitaram a multidão, que reagiu de acordo, contra os armênios, demonstrando a crescente animosidade da população. A fotografia acima serve de exemplo do que os autores querem representar quando tratam da "ferocidade" dos ataques. Também serve para uma reflexão diante da declaração turca de que os armênios só eram atacados porque se revoltavam: é evidente que as crianças não poderiam ser líderes revolucionários. Esse resumo será útil para a análise dos acontecimentos de 1914-1916 que veremos mais à frente.

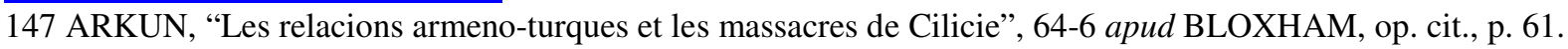


Ao comparar os relatos de cada autor, pode-se notar também a tendência de cada um a apoiar um e outro lado. Verificar essas tendências será importante para o pesquisador que deseje realmente chegar aos fatos, pois a todo momento é necessário eliminar os exageros.

Logo após a retomada do poder pelo CUP, o ex-Sultão e sua família foram imediatamente colocados em um trem para Thessalônica, fato que impediu qualquer reação contrária à sua deposição. Seguiu-se então um período de comando democrático, multipartidário: um desastre, devido às pressões internas e externas que nunca deixaram de existir. O novo governo devia enfrentar a invasão da Itália a Trípoli e Bengazi, bem como a crescente tensão que pouco mais tarde levaria às guerras balcânicas. Houve uma tentativa de modernização militar, com novos canhões, navios, armas e também especialistas estrangeiros para o treinamento, cujas ordens os muçulmanos tinham dificuldade em seguir, pois não se conformavam em obedecer a um gâvur (infiel).

A revolta da Albânia, nos primeiros meses de 1910, segundo Shaw, mostrou aos turcos que seria impossível conciliar interesses nacionais tão distintos dentro de um mesmo império. As estratégias liberais falharam ao tentar impedir o declínio do império e, então, os "Jovens Turcos" passaram gradualmente de sua visão original de um império baseado em garantias civis e direitos das minorias para uma ideologia nacionalista turca com ênfase no domínio turco. ${ }^{148}$ Nesse momento, o otomanismo deixou definitivamente de ser uma tendência política, enquanto que o nacionalismo turco determinaria as ações daí em diante ${ }^{149}$.

Ainda assim, os líderes do CUP nunca concordaram com uma orientação ideológica única, sendo várias as tendências dentro do partido. Alguns autores apontam o sociólogo Ziya Gokälp, o idealizador da noção do pan-turanismo, onde Turan seria o lar imaginário de todos os turcos da Ásia Central, como o elemento de influência ideológica entre os líderes do governo central do CUP e precursor do genocídio armênio ${ }^{150}$. Entretanto, de acordo com Lewy, Gokälp fazia parte apenas de um pequeno grupo dentro do partido e ainda assim, sua ideia de turanismo nunca chegou a ser um programa de ação. ${ }^{151}$

Dadas as divergências internas do partido, parece mais provável que a direção tomada pelo governo central tenha sido muito mais influenciada pelas pressões externas e internas que enfrentavam do que por qualquer ideologia política pré-estabelecida. As guerras por território seguiam sendo motivo de desespero para a Sublime Porta. Em setembro de 1911, a Itália

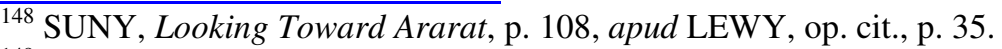

${ }^{149}$ Diferencia-se Otomanismo de Turquismo pois o primeiro pretendia encontrar uma forma de contentar a todas as nacionalidades 'otomanas' no império e o último prescrevia a 'Turquia para os turcos'.

${ }^{150}$ Vahakn Dadrian é o mais citado entre os autores que sustentam essa visão.

${ }^{151}$ LEWY, op. cit., p. 35.
} 
invadiu a Tripolitania (atual Tripoli) sob pretexto de que os italianos locais estavam sendo ameaçados pelos muçulmanos. ${ }^{152}$

Durante a guerra com a Itália, o CUP procurou reconquistar a popularidade fazendo um boicote aos produtos italianos e conseguindo que o Parlamento abolisse as Capitulações italianas. Ainda assim, formaram um governo de coalizão com outros partidos. A pressão italiana, que ocupou as Ilhas do Dodecaneso, acabou por reforçar a opinião pública em favor do CUP, como a única força administrativa capaz de enfrentar o problema. O Comitê voltou à cena com mais poder que antes, entretanto, a fim de enfrentar a aliança dos estados balcânicos, assinou um acordo de paz dando vitória à Itália em outubro de 1912. As trocas de cabeças no gabinete se tornaram mais frequentes, até o momento em que estourou a Primeira Guerra Balcânica. Sem fôlego para enfrentar essa coalizão, a guerra mostrou-se catastrófica para o Império. Além de perder a maior parte de suas possessões europeias, o búlgaros sitiaram Edirne, a antiga capital, e avançavam contra Istambul. Milhares de refugiados chegavam do norte, espalhando a confusão nas ruas da capital imperial. O povo culpava o governo. Edirne sitiada provocou uma reação drástica dos membros do CUP - acreditando que o Grão Vizir iria entregar a cidade, em janeiro de 1913, Enver Bey liderou o 'golpe à Sublime Porta' e forçou a demissão do Primeiro Ministro sob a mira de sua pistola. Em abril, após um armistício, foi assinado o Tratado de Londres, encerrando o conflito. Os liberais assassinaram Mahmut Sevket, o ministro da guerra, dando ao CUP uma outra chance: os assassinos foram presos e julgados e a União Liberal execrada pela população. O Comitê voltou mais uma vez ao topo e, desta vez, sem opositores, inaugurando uma ditadura que somente terminou com a derrota na Primeira Guerra Mundial, em 1918.

Apesar da nova vitória, o CUP arcou com o peso da mutilação do Império Otomano ao assinar o Tratado de Constantinopla em setembro de 1913. O governo otomano aceitou a perda de quase $20 \%$ do seu território total (98\% das terras europeias, 100 mil Km quadrados), incluindo excelentes terras agriculturáveis e as melhores zonas comerciais do império, além de quase quatro milhões de habitantes pagadores de impostos ${ }^{153}$. Cerca de 400 mil refugiados muçulmanos saíram dos países agora independentes sob governo cristão e buscaram refúgio no Império, aumentando a pressão social. Apesar desses revezes, pela primeira vez na história, os turcos se tornaram maioria da população. ${ }^{154}$

${ }^{152}$ ZURCHER, op. cit., p. 105.

${ }^{153}$ BLOXHAM, op. cit., p. 62.

${ }^{154}$ ZURCHER, op. cit., p. 109. 


\section{Triunvirato do CUP}

Logo após o retorno do CUP ao topo do gabinete, os acordos de paz definiram as fronteiras ao final da Segunda Guerra Balcânica, com a cidade de Edirne de volta ao Império. Edirne foi a antiga capital do reino de Osman, tendo sua história ligada à do próprio Império Otomano, razão pela qual seu retorno ao domínio do Sultão aumentou sobremaneira o prestígio do Comitê. Oficialmente, quem comandava o país nesse momento era o Grão Vizir Sait Halim Pasha, mas o verdadeiro poder estava nas mãos dos líderes do CUP, mais especificamente em três de seus membros: Talaat Pasha, ministro do interior, o gênio administrativo, Djemal ${ }^{155}$ Pasha, homem de armas, severo e impiedoso com os inimigos e Enver Pasha, o herói público, carismático soldado e totalmente patriótico.
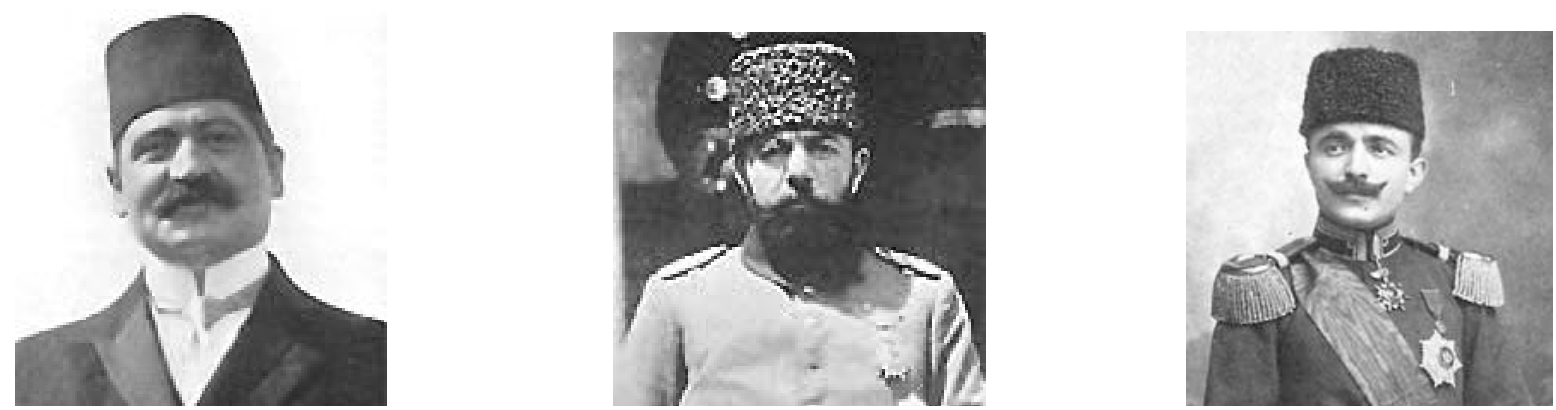

11 - Líderes do CUP, de 1913 a 1918 - da esquerda para a direita: Talaat Pasha, Djemal Pasha e Enver Pasha

O peso do poder não parecia ser um problema, embora os problemas a serem resolvidos seguissem tão numerosos quanto antes e o império estivesse a um passo da decisão de entrar ou não na guerra que se anunciava, e de que lado. A essa altura, toda a ideia de otomanismo, igualdades sociais e religiosas, tudo isso já havia sido esquecido. As perdas territoriais ajudaram a levar a opinião pública para o nacionalismo estrito: as minorias do império perderiam toda esperança de apoio.

O CUP no poder empenhou-se na continuação das modernizações iniciadas há tanto tempo. A burocracia estatal precisava ser adaptada às novas dimensões do novo país, os refugiados alocados em algum lugar onde fossem úteis e devia ser combatido o 'terrorismo' das minorias. Uma das atitudes mais importantes foi a modernização das Forças Armadas. Para isso, contaram com o inestimável auxílio da Alemanha. Alemães ocuparam postos de

$\overline{155}$ Também pode ser encontrada a grafia Cemal. 
comando e treinaram os oficiais turcos. Essa gentileza teria um preço alto. A princípio, a intenção do império era manter-se neutro na guerra, mas o comando alemão decidiu fechar a passagem no Estreito de Dardanelos, o que vinha a ser o mesmo que declarar guerra à Rússia e aos aliados, deixando o CUP sem escolha. ${ }^{156}$

"De fato, o único factível. Esse era o estreito portão por onde passavam $9 / 10$ das exportações e importações russas, durante anos. Ao fechar subitamente essa passagem, os alemães destruíram a Rússia econômica e militarmente. Também impediram que munições inglesas e francesas chegassem aos russos em quantidade suficiente para enfrentar os alemães. Sem disparar nenhum tiro e sem custar nenhuma vida, em um piscar de olhos, a Alemanha conseguiu o que provavelmente três milhões de homens em frente ao bem equipado exército russo não conseguiriam. Esta foi uma das mais dramáticas vitorias militares durante a guerra e foi resultado da propaganda, penetração e diplomacia alemãs."157

\subsection{1 - Práticas genocidas: política de limpeza étnica}

Apesar de toda a controvérsia entre tantos estudiosos interessados no assunto, existe um ponto com o qual todos concordam: um número assombroso de armênios que, de fato, perderam suas vidas durante a Primeira Guerra Mundial em território otomano. Os números podem variar dependendo da fonte consultada: autores armênios chegam a 1,5 milhão ${ }^{158}$ enquanto os turcos falam em 600 mil $^{159}$; mas ninguém nega a evidência de que as mortes ocorreram e foram centenas de milhares.

A alegação, e a negação em contrapartida, de que essas mortes tenham configurado um crime de genocídio, depende principalmente da prova da intenção estatal de matar essas pessoas e é esse o principal ponto de choque entre os autores pró-armênios e pró-turcos. É fato que poucos documentos escritos e autenticados podem ser apresentados como prova da intenção genocida e esse fato é acionado, muitas vezes, como ferramenta para o negacionismo. Um pesquisador que procure manter-se imparcial diante deste momento histórico terá que evitar armadilhas de ambos os lados. É natural que, ao tentar defender sua versão, cada lado apele para o exagero, é parte da natureza humana. Entretanto, esses exageros são utilizados pelo 'adversário' com muita eficiência, transformando as dúvidas em certezas manipuladas.

\footnotetext{
${ }^{156}$ MORGENTHAU, op. cit., p. 105-108.

${ }^{157}$ Idem, p. 109.

${ }^{158}$ Dadrian, em várias obras.

${ }^{159}$ Site de internet do Ministério do Turismo da Turquia: www.kultur.gov.tr
} 
Um dos melhores exemplos desta disputa entre "história" e "verdade histórica" é o caso dos famosos telegramas de Talaat Pasha. Quase todos os textos armênios citam os telegramas enviados pelo então Ministro do Interior - e ex-chefe dos correios e telégrafos aos governadores das províncias, os quais continham ordens expressas sobre quando e como conduzir as deportações dos armênios. Se aceitos como autênticos, esses telegramas são evidencias incriminatórias para a acusação de genocídio. ${ }^{160}$ Tais telegramas foram apresentados em Tribunal, durante o julgamento de Salomon Teilirian, armênio, assassino confesso de Talaat em 1921, em Berlim. A intenção da defesa era provar que o réu cometeu o crime por estar convicto de que Talaat era o responsável pelo aniquilamento de seu povo. ${ }^{161}$ Esses documentos teriam chegado às mãos dos armênios quando a força aliada ocupou Constantinopla, sendo entregues por Naim Bey, um dos oficiais turcos responsáveis pelo comitê de deportações em Aleppo. Naim entregou a Aram Andonian as suas memórias, que continham muitos documentos oficiais, telegramas e decretos que passaram por suas mãos enquanto estava no cargo. ${ }^{162}$

Esses controversos documentos são motivo para as mais acirradas discussões. Praticamente todos os autores armênios e muitos outros pesquisadores de renome, como Robert Melson e David Lang, os aceitam como genuínos, enquanto a defesa turca refere-se a eles como "conto armênio". ${ }^{163}$ Aqueles que acreditam tratar-se de falsificação, ou os que não deixam claro sua posição, como Lewy, questionam a origem, afirmando que Naim Bey, enquanto secretário, não poderia ter acesso a esse tipo de documentos altamente confidenciais. Afirmam que não há provas de que sejam verdadeiros, pois as assinaturas telegráficas são fáceis de falsificar, entre outros argumentos bastante coerentes.

Entretanto, se não há forma de confirmar a veracidade destes registros, tampouco existe meio de provar que são falsos, fato que nunca é levantado. Naim Bey era secretário do comitê em Aleppo, para onde se dirigiram a maior parte dos deportados. É também coerente afirmar que o responsável pela execução das ordens de deportação naquela cidade devia receber essas ordens de alguma forma e já vimos que desde a época do sultão, os turcos consideravam de grande importância a rede telegráfica, o que nos leva a concluir que a comunicação com o governo central devia ser feita por esse meio.

\footnotetext{
${ }^{160}$ LEWY, op. cit., p. 64.

${ }^{161}$ PASCHOAL, Erlon (trad.) Um Genocídio em Julgamento - o Processo de Talaat Pasha na República de Weimar. São Paulo, Paz e Terra, 1994, p. 139.

${ }^{162}$ LEWY, op. cit., p. 63. - Nota: o autor cita diversos trechos dos documentos, mas não fica claro se acredita na sua autenticidade.

${ }^{163} \mathrm{http}: / / \mathrm{www}$. tallarmeniantale.com/
} 
Ora, se chegam telegramas, o secretário em serviço pode ter tido oportunidade de ter contato com eles. O Ministro Talaat, antigo funcionário dos correios e telégrafos, de acordo com as memórias do Embaixador Morgenthau ${ }^{164}$, tinha um telégrafo particular em sua própria residência, e o utilizava com frequência. Portanto, é possível que tenha enviado pessoalmente ordens diretas aos seus subordinados. É possível, mas não pode ser provado ${ }^{165}$. Como quase tudo nessa história, essa é mais uma ponta do emaranhado: tanto pode ser exagero armênio no afã de ver reconhecido seu luto, como pode ser exagero turco, em defesa de seus heróis nacionais.

Existem fatos 'secundários' 166 aos massacres, entretanto, que podem fazer pender a balança armênios/turcos. Esses fatos raramente são mencionados ou foram desprezados durante muitos anos, esquecidos em memórias poeirentas. Não são sequer citados nas 'perguntas frequentes' do site oficial turco, máximo instrumento de defesa contra as alegações armênias. ${ }^{167}$ Falamos do tratamento empregado pelo governo dos "Jovens Turcos" para com as comunidades gregas do Império, antes do início da grande guerra. Ao analisar essa atitude, à luz do que ocorreu pouco mais tarde com os armênios, pode-se perceber um traço conectivo, uma linha de conduta iniciada antes, bem antes, dos desertores armênios começarem a ameaçar as linhas otomanas do front. ${ }^{168}$

Desde o boicote aos 'produtos austríacos' iniciado após a anexação da BósniaHerzegovina em 1908, que afetou diretamente os negociantes cristãos, era intenção declarada do governo otomano diminuir a imensa dominância econômica dos cristãos dentro do império:

"Boicotes comerciais foram parte da estratégia sugerida contra os cristãos pelos jovens turcos radicais, ainda antes do golpe de 1908. Usando o pretexto da anexação da Bósnia pela Áustria e de Creta pela Grécia, os boicotes visavam a Áustria e depois os cristãos otomanos. Em 1909 houveram sanções contra os comerciantes gregos que foram renovadas em 1910 e com maior energia em 1913-14. A política antigrega alcançou seu final sob o CUP nesses anos e em 1915-16, em uma combinação de engenharia populacional e apropriação econômica, usando boicotes, assassinatos, terror e depois deportações de partes da população grega da Anatólia ocidental." ${ }^{169}$

\footnotetext{
$\overline{{ }^{164} \text { MORGENTHAU, op. cit., p. } 143 \text {. }}$

${ }^{165}$ Importante lembrar que no caso do Holocausto dos Judeus, também não foram encontrados documentos por escrito ou assinados por Hitler e ainda assim, o caso é reconhecido como genocídio.

${ }^{166}$ Uso o termo 'secundários' apenas para distinguir entre o peso moral de um assassinato em massa e da expulsão da população, por exemplo, sem (muitas) vítimas fatais .

${ }^{167}$ http://www.mfa.gov.tr/questions.en.mfa\# em janeiro de 2013

${ }^{168}$ A traição dos armênios, que atacavam as tropas otomanas 'pelas costas' é a principal justificativa turca para o início das deportações.

${ }^{169}$ BLOXHAM, op. cit., p. 64.
} 
Os planos traçados para a turquificação da Anatólia foram cuidadosamente estudados. A princípio, o CUP "tomou uma decisão clara. A fonte de problemas na Anatólia ocidental devia ser removida, deveria 'limpar' os gregos, por meios políticos ou econômicos. Antes de qualquer coisa, era preciso enfraquecer os economicamente poderosos gregos". ${ }^{170}$

"O plano era transportar os gregos para as ilhas do egeu. Naturalmente, os gregos se rebelaram contra esse tratamento e massacres ocasionais foram o resultado, especialmente na Fócia, onde mais de 50 pessoas foram mortas. Os turcos ordenaram que todos os estabelecimentos estrangeiros em Esmirna demitissem seus empregados gregos e admitissem muçulmanos. Entre os interesses americanos, a fábrica Singer recebeu essas instruções e embora eu tenha conseguido um prazo de 60 dias, ao final também tiveram que obedecer ao mandado. Um boicote oficial foi estabelecido contra todos os cristãos, não apenas na Ásia Menor, mas também em Constantinopla, mas esse boicote não afetava os judeus, que sempre foram mais populares na Turquia que os cristãos. Os oficiais particularmente pediam aos comerciantes judeus que pusessem avisos em suas portas, indicando a nacionalidade e o tipo de negócio - esses avisos como 'Abraham o judeu, alfaiate', 'Isaac o judeu, sapateiro'.,"171

O início das atividades antigregas deveria ser ao redor da região de Esmirna/Izmir, onde havia maior concentração de 'poderosos gregos'. No entanto, um relatório de Kuşçubaşi, um oficial turco enviado à região, afirma que as influências externas tornariam muito difícil a turquificação daquela região, além de afirmar que qualquer ação local colocaria o governo otomano sob suspeita das grandes potências, por isso, o esforço de nacionalização deveria ser levado por compatriotas sérios, resolutos e com muita força de vontade. ${ }^{172}$

Ainda sem a cobertura da guerra, o governo Unionista temia agir e provocar uma intervenção estrangeira. Daí então a Organização Especial ${ }^{173}$ ter realizado um trabalho 'disfarçado': roubos, sequestros, campanhas de terror, ataques de bandos armados. Desse modo, não havia envolvimento estatal aparente, embora empregasse oficiais de alto escalão para monitorar o trabalho de "limpeza":

“A operação de 'limpeza' no Egeu foi implementada militarmente pelo Chefe de Staff Cafer Tayyar Bey, do $4^{\circ}$ Regimento, sob comando de Pertev [Demirhan] Pasha, e pelo governador da província de Izmir, (...) Rahmi Bey, diretor administrativo local, por determinação do Partido de União e Progresso. As forças estatais agiriam de acordo com ordens do Ministro da Guerra e do Supremo Comando Militar, para implementar esse plano." 174

Existe nesse episódio referência à formação de 'batalhões de trabalho', quando jovens foram levados ao interior para construir estradas em condições sub-humanas, uma das

\footnotetext{
$\overline{170}$ NURDOĞAN Taçalan, Ege'de Kurtuluş Savaşi Başlarken (Istambul, 1970) p. 65 apud AKÇAM, op. cit., p. 103.

${ }^{171}$ MORGENTHAU, op. cit., p. 50.

172 BAYAR, Ben de Yazdim, vol. 5 p. 1576, apud AKÇAM, op. cit., p. 103.

${ }^{173}$ Ver referência à Organização Especial mais à frente neste capítulo.

${ }^{174}$ KUTAY, Birinci, p.62, apud AKÇAM, op. cit., p. 104.
} 
estratégias do genocídio por vir. Apesar dos cuidados, houve repercussão e uma forte reação na Europa, o que deteve os trabalhos. Uma comissão de inquérito foi estabelecida, liderada por Talaat Pasha, incluindo membros de cada embaixada. ${ }^{175}$

Durante a guerra, a migração forçada dos gregos voltou a ocorrer, desta vez organizada pelo general alemão Otto Liman Von Sanders, que enviou um relatório ao governo otomano dizendo que ele seria incapaz de manter a segurança das tropas se essas recolocações não fossem realizadas. Da cidade de Ayvalik, na costa do Egeu, por exemplo, toda a população entre 12 e 80 anos foi relocada para o interior da Anatólia. No relatório, Von Sanders inclui a pergunta retórica "não podemos jogar esses infiéis no mar?"176 O mesmo Von Sanders, em depoimento durante o julgamento de Teilirian em Berlim, afirmou:

"posso dizer de nós [alemães] - porque como o doutor Leipsius teve a bondade de salientar, fomos considerados em larga medida suspeitos - que nenhum oficial alemão colaborou com qualquer medida contra os armênios. Pelo contrário, intervimos onde pudemos". ${ }^{177}$

Em suas memórias, o embaixador americano Henry Morgenthau relata o modo como os gregos foram tratados:

"primeiro incorporados ao exército, depois agrupados em 'batalhões de trabalho' levados para construir estradas, no Cáucaso e outros locais, onde morreram aos milhares. Depois patrulhas procurando armas de casa em casa, conversões forçadas, meninas gregas foram levadas para haréns muçulmanos, deportações a pé, para locais distantes. Tudo isso, exatamente do mesmo modo como agiram com os Armênios, com a diferença de que os gregos não foram submetidos aos massacres vistos no caso armênio, o que, segundo ele, foi o que fez com que sua história não fosse tão conhecida, embora mais de 200 mil gregos tenham perecido desse modo". ${ }^{178}$

O caso dos gregos foi menos destrutivo e, para esta questão podemos levantar algumas hipóteses explicativas: a Grécia era um Estado Nacional reconhecido e apoiado internacionalmente e, apesar de não ter autoridade sobre os 'gregos' otomanos, poderia levantar a opinião pública internacional contra os turcos, por exemplo. Além disso, havia uma preocupação quanto à adesão ativa da Grécia aos aliados, o que seria um problema durante a guerra, por conta de uma base territorial excelente para as tropas da Entente. ${ }^{179}$ Enfim, o fato é que os gregos otomanos foram igualmente perseguidos antes e durante a Primeira Guerra. Autores como Tessa Hoffman, afirmam que também os assírios (outra minoria cristã)

\footnotetext{
$\overline{175}$ BAYUR, op. cit. vol 2, parte 3, p. 255, apud AKÇAM, idem.

${ }^{176}$ Meclisi Mebusan Zabit Ceridesi, Period 3, Assembly Period 5, vol 1,23 Teşrinisani 1334 (23 Novembro 1918) 17. Inikad,p.186, apud AKÇAM, ibidem.

${ }^{177}$ PASCHOAL, op. cit., p. 128.

${ }^{178}$ MORGENTHAU op. cit. p. 324-325.

${ }^{179}$ O Rei Constantino não permitiu que a Grécia entrasse na guerra até que foi expulso do país por pressão da potências europeias. A partir de 1917, o país governado pelo Primeiro Ministro Eleftérios Venizelos se aliou às tropas da Entente.
} 
sofreram os mesmos tratamentos no Império Otomano naquele momento. Esse fato permite reavaliar as alegações de defesa do governo turco quanto à necessidade de deportações armênias por não serem 'um povo confiável': caem por terra, pois o mesmo mecanismo já vinha sendo utilizado para resolver questões com os demais cristãos do Império, antes da guerra.

Entretanto, os armênios eram realmente uma ferida aberta no orgulho nacional turco. Em especial porque pretendiam amputar a porção mais nobre do Império, ao contrário dos demais 'rebeldes' - búlgaros, gregos, sérvios, etc. - que tomaram regiões periféricas. A independência armênia causaria um "buraco" no centro do território otomano, algo impensável, que devia ser evitado a qualquer custo. Para evitar esse desastre políticogeográfico, o governo do CUP se valia de cada oportunidade emergente.

\subsection{2 - A "Questão Armênia"}

\section{A “Revolução" de Van}

O episódio de Van poderia ser apontado como o início das deportações pois, logo após esse confronto, foi promulgada a Lei de Deportações, que determinou o destino dos armênios. A história da "Revolução" de Van recebeu diferentes versões com explícitas divergências de fontes, assim como ocorreu com o "levante" de Adana em 1909. Entendemos que a multiplicidade de versões em fatos "chave" como estes, ratifica o peso da política negacionista, tornando necessária a análise das diversas opiniões.

O Embaixador Americano Morgenthau faz um relato bastante extenso, mas revelador, sobre este episódio:

"A localização da vila inevitavelmente a fazia ser cena de operações militares e fazia as atividades dos armênios um caso de suspeita diária. Se a Rússia decidisse invadir a Turquia, uma das rotas mais fáceis passava por aí. A guerra não havia ido muito longe quando as causas de irritação começaram. As requisições de suprimentos para o exército eram muito mais pesadas para os cristãos, assim como em todas as demais províncias. Os armênios tinham que ficar quietos enquanto os oficiais turcos levavam todo seu gado, seu trigo e bens de todos os tipos, dando em troca apenas um pedaço de papel. A tentativa de desarmamento geral que aconteceu ali também aumentou sua apreensão, que já estava aumentada pelo tratamento brutal para com os soldados armênios no Cáucaso. Por outro lado, os turcos fizeram muitas acusações à população cristã e de fato, atribuíram a eles os reveses sofridos pelo exército turco no Cáucaso. 
Os turcos afirmaram que grande número de soldados armênios desertaram, cruzaram a fronteira e se juntaram ao exército russo, onde seu conhecimento das estradas e do terreno teria sido importante para as vitorias russas. Apesar desses fatos ainda não terem sido confirmados, não parece impossível que essas deserções, talvez algumas centenas, realmente tenham ocorrido.

No início da guerra, agentes do CUP apareceram em Erzeroum e Van e apelaram aos líderes armênios para ir a armênia russa e tentar começar uma revolução contra o governo russo; e o fato de que os armênios otomanos se recusaram a fazer isso contribuiu ainda mais para a irritação já em curso. (...)

Por anos tinha sido política turca provocar a população cristã a cometer atos abertos e então aproveitar esses atos como desculpa para massacres. Os clérigos armênios e os líderes políticos viram muitas evidencias de que os turcos estavam de volta a suas antigas táticas, e eles então foram ao povo, avisando-os para permanecerem quietos, para aguentar todos os insultos e mesmo ataques pacientemente, para não dar aos muçulmanos a abertura que procuravam. "Mesmo que eles queimem algumas de nossas vilas", esses líderes diziam, "não façam retaliação, pois é melhor que alguns sejam destruídos que uma nação inteira ser massacrada".

No início da primavera, os russos se retiraram temporariamente. É prática reconhecida como boa tática militar que o exército vitorioso siga o exército em retirada. Aos olhos dos generais turcos, entretanto, a retirada dos russos era uma boa reviravolta da guerra, já que deixava os armênios privados de seus protetores e à mercê do exército turco. Ao invés de seguir as tropas em retirada, portanto, os turcos se voltaram e atacaram seu próprio território. Ao invés de lutar com os exércitos russos bem treinados, eles voltaram seus rifles, metralhadoras e outras armas para as mulheres, crianças e velhos armênios de Van. Seguindo seu costume, eles distribuíram as mulheres mais bonitas entre os muçulmanos, saquearam e queimaram vilas e massacraram ininterruptamente por dias. Em 15 de Abril, cerca de 500 jovens armênios de Akantz foram reunidos para ouvir uma ordem do sultão; ao pôr do sol eles foram levados para fora da cidade e mortos friamente com tiros. Esse procedimento foi repetido em aproximadamente 80 vilas armênias do distrito norte do lago Van, e em 3 dias, 24 mil armênios foram mortos dessa forma atroz.

Então, quando Djevdet, ao retornar ao seu posto oficial, requisitou $4 \mathrm{mil}$ soldados, naturalmente o povo não estava inclinado a aceitar sua requisição. Quando consideramos o que já havia acontecido e o que aconteceu em seguida, não resta dúvidas do propósito dessa demanda. Sua intenção ao convocar 4 mil soldados era massacrá-los e deixar o resto da população sem defesa. Os armênios, para ganhar tempo, ofereceram 500 soldados e pagar pela isenção do restante. Agora Djevdet começou a falar em "rebelião" e sua determinação de reprimi-la a todo custo. "Se os rebeldes derem um só tiro", ele declarou, "vou matar cada homem cristão, cada mulher e (apontando para o joelho) cada criança deste tamanho."

Em 20 de abril, um bando de soldados turcos prendeu um grupo de mulheres armênias que entravam na cidade. Alguns armênios correram para ajuda-las e foram mortos a tiros. Então os turcos abriram fogo pelo bairro armênio com rifles e artilharia; logo uma grande parte da cidade estava em chamas e um cerco foi fechado. A resistência armênia consistia de 1500 homens; eles tinham 300 rifles e pouca munição, enquanto Djevdet tinha 5 mil homens, completamente armados e equipados. Os armênios não tinha chance de resistir por muito tempo, mas sabiam que o exército russo estava lutando para chegar a Van e sua esperança era de que conseguissem segurar o cerco até que os russos chegassem. (...)

Eu contei essa história sobre a "revolução" de Van não só porque ela marcou o primeiro estágio dessa tentativa organizada de eliminar uma nação, mas porque esses eventos são mostrados sempre pelos turcos como justificativa para seus crimes subsequentes. Como vou contar, Enver, Talaat e o resto (sic), quando eu apelei a eles pelos armênios, invariavelmente falavam de "revolucionários" de Van como um exemplo de traição armênia. A famosa "revolução", como esta narração mostra, foi apenas a 
determinação de alguns armênios de salvar suas mulheres e suas vidas, após os turcos, matando milhares de seus vizinhos, haviam mostrado o destino que os aguardava. ${ }^{180}$

Para o historiador Zurcher,

"Apesar de não confiar muito na sua capacidade bélica, os alemães traçaram várias estratégias ofensivas para o exército otomano, com a aprovação entusiástica de Enver. Em janeiro, após um bom início, as tropas otomanas sofreram uma derrota arrasadora em Sarikamiş, perdendo 4/5 dos homens, principalmente de frio e fome, enquanto tentavam atravessar o Cáucaso em pleno inverno. O fiasco militar permitiu grande avanço russo e também marcou o início da supressão dos Armênios Otomanos, assunto ainda controverso. (...)

Com o início da guerra, os nacionalistas armênios viram numa vitória russa a sua chance de estabelecer um estado armênio. Alguns milhares de armênios entraram para o exército russo, houveram deserções de armênios do exército otomano e guerrilha por trás das linhas otomanas. Confrontados com esta situação, o exército Otomano iniciou algumas deportações esporádicas nas áreas atrás do front. Alguns pequenos massacres ocorreram. No final de março, a liderança do CUP tomou provavelmente a decisão de realocar toda a população armênia da zona de guerra para Zor, no coração do deserto sírio e mais tarde, de lá para a síria e mesopotâmia. Uma reação dos armênios de Van estreitou o sentimento de urgência. As deportações começaram em maio." 181

A versão do governo turco enfatiza que:

"O início da Primeira Guerra Mundial e a entrada do Estado Otomano na guerra contra os aliados foram vistos como a grande oportunidade por esses grupos revolucionários. Eles se revoltaram contra o governo Otomano, colaboraram com o Exército Russo invasor e outras forças estrangeiras, lançando ataques ao exército Otomano e civis muçulmanos por trás do front e envolvendo-se em atos de sabotagem. Em março de 1915, as forças russas começaram a se mover na direção de Van. Após o fracasso da Operação Sarıkamış, em 11 de Abril de 1915, os armênios de Van iniciaram uma revolta geral que foi a segunda rebelião dos armênios de Van, massacrando todos os turcos nos arredores para proporcionar a fácil conquista da cidade pelos Russos. Como resultado, o governo Otomano promulgou a Lei de Relocação em 27 de Maio de 1915. Os armênios que viviam ao redor de locações militares estratégicas deviam ser relocados para outras áreas longe da zona de guerra.

Quando analisamos os eventos de 1915 no contexto histórico, o Governo Otomano que enfrentava enormes traições internas e externas como os ataques terroristas, rebeliões e cooperação com inimigos lançou mão de medidas defensivas e precauções aumentadas. Sendo assim, essas precauções não foram pré-planejadas e não tem um objetivo político baseado em certa ideologia. Ao contrário, foram implementadas devido a necessidades militares e de segurança.

Historiadores militares dizem que o Governo Otomano foi forçado a promulgar a Lei de Relocação em 27 de Maio de 1915 devido a necessidades militares e a ameaça de movimentos separatistas."182

\footnotetext{
${ }^{180}$ MORGENTHAU, op. cit., p. 293-300.

${ }^{181}$ ZURCHER, op. cit., p. 112-114.

182 Trecho do texto explicativo para a pergunta "o que aconteceu em 1915" na seção Perguntas Frequentes do site oficial do Ministério das relações exteriores da Turquia - http://www.mfa.gov.tr/questions.en.mfa, consultado em abril de 2013.
} 
É fato que muitos armênios desertaram das fileiras otomanas e fugiram para o front russo. Com certeza o início da guerra foi uma excelente oportunidade, tanto para revolucionários armênios como para os adeptos da turquificação completa do país. As diferentes descrições a respeito da "Revolução" de Van, obviamente, correspondem aos interesses de cada um dos autores comprometidos com sua identidade ideológica. Importante esclarecer que o embaixador Morgenthau não estava presente em Van, mas ouviu narrativas dos missionários americanos Clarence e Elizabeth Ussher e Grace Knapp, durante uma entrevista na Embaixada Americana em Istambul, após a expulsão dos missionários de Van pelos agentes do governo otomano. Lembramos que o embaixador americano permaneceu em seu posto e esteve em contato frequente com os líderes do CUP durante todo o período em que ocorreram as deportações. Somente em abril de 1917, quando os Estados Unidos se uniram às forças aliadas, é que os embaixadores americanos deixaram o país. Consideramos a descrição de Morgenthau de alto valor, pois sua posição pode ser confirmada pelos documentos diplomáticos enviados ao governo de seu país, que estão disponíveis para consulta pública.

Consideramos importante ressaltar a negativa explícita da premeditação, encontrada no site do governo turco. Esse ponto tem especial importância pois, em questões legais, uma das prerrogativas mais importantes para que o crime seja considerado genocídio é a intenção de matar, a premeditação do processo. Por essa razão, em todo o texto disponível no site, identificamos várias vezes esse tipo de negativa: 'não foi um ato premeditado', 'o governo não deu as ordens'.

Entendemos que os fatos ocorridos em Van devem ser avaliados como um ato de heroísmo por parte dos armênios, tentando evitar a sorte que se anunciava. Eles já conheciam o destino dos soldados enviados aos batalhões de trabalho e já haviam tido notícia das deportações dos gregos da costa do Egeu, ocorridas no ano anterior. Talvez o que eles não soubessem naquele momento, era que não podiam esperar nada de muito bom por parte do governo otomano, assim como de outros países. A Rússia tinha seus motivos para aceitar desertores armênios em suas linhas e atacar os turcos que sitiavam Van, mas seus motivos não eram apenas de ordem humanitária. Se fossem, é pouco provável que seus exércitos não tivessem condições de impedir ou interromper as deportações. As grandes potências europeias recuaram diplomaticamente quando o governo otomano os rechaçou exigindo que não se metessem em assuntos domésticos. Evidente que a 'humanidade' dos líderes russos, ingleses e 
franceses foi testada diversas vezes no decorrer desses conflitos e, em nenhum momento, superou a força dos interesses políticos.

\section{A “intenção" através das Leis}

Quase todos os autores que lidam com esse assunto se preocupam, com razão, em esclarecer a questão "genocídio ou massacre" com base em documentos autênticos, declarações oficiais e depoimentos de personagens chave. Infelizmente, após um século, ainda não foi possível chegar a um veredicto final, pela via legal, a respeito da real intenção do governo central otomano de liquidar os armênios. A comunidade armênia mundial tem pressionado por reconhecimento e muitos pesquisadores apresentam argumentos e documentos, todos refutados pelo governo turco. O impasse segue, sob a alegação de que faltam provas irrefutáveis.

Entretanto, quando nos desviamos um pouco da via legal, como é a proposta deste estudo, e nos concentramos na via humana, fica mais fácil perceber um conjunto de ações que nos oferecem alguns indícios interessantes. Quando falamos em 'via humana', nos referimos ao não-oficial, aos sinais nas entrelinhas dos registros, como por exemplo as leis promulgadas sobre o assunto.

Primeiramente, o governo otomano aprovou a Lei de Associação, que proibia qualquer associação, grêmio ou clube das minorias do Império. Mais tarde, em 27 de maio de 1915, foi promulgada a Lei de Relocação, cujo primeiro artigo autoriza os comandantes do Exército, das divisões e regimentos a "tomar medidas militares contra os oponentes às ordens do governo, à defesa do país e à proteção da paz; e contra aqueles que organizarem ataques e resistência armada e matarem rebeldes durante a agressão e se rebelarem em tempo de guerra." 183

O segundo artigo autoriza os mesmos comandantes a

"transferir e relocar individualmente ou em massa, as pessoas vivendo em vilas e cidades que estiverem envolvidas em espionagem ou traição. As propriedades dos armênios sujeitos à imigração estavam protegidas sob um ordem datada de 10 de junho de 1915. Uma 'Comissão para Propriedades Abandonadas' compreendendo um presidente e dois membros, um administrativo e um financeiro, foi estabelecida. Essa comissão deveria determinar quais as propriedades armênias nas vilas e cidades evacuadas, e conservar livros de registro detalhados. Um dos livros deveria ser conservado nas igrejas regionais, um submetido à administração regional e outro conservado pela comissão. Bens não duráveis e rebanhos de animais deveriam ser vendidos e o dinheiro guardado. Em lugares onde a comissão não fosse apontada, as provisões do comunicado deveriam ser exercidas

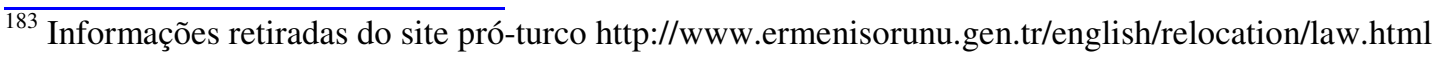


pelos oficiais da região. Tanto a comissão como os administradores regionais deviam ser responsáveis pela proteção dessas propriedades até o retorno dos armênios." 184

A Lei de Relocação foi promulgada oficialmente pelo governo otomano e colocada em prática pelos oficiais militares e administradores regionais, conforme a determinação legal. Suas determinações são, portanto, 'intenção estatal'. Diante disso, é possível seguir uma linha de raciocínio referente às intenções do governo: todos conheciam as condições das estradas no interior da Anatólia, assim como todos sabiam que a viagem seria exaustiva demais para qualquer ser humano, principalmente nas condições em que as marchas foram iniciadas, sem comida, sem transporte.

A própria Lei de Relocação, ao ser instituída, já era sentença de morte para muitos. Qualquer pessoa seria capaz de saber que uma mulher grávida ou com um bebê nos braços, crianças pequenas ou idosos, jamais seriam capazes de empreender uma viagem de quinhentos, seiscentos quilômetros em meio ao deserto, ou durante nevascas. Mesmo que fossem bem alimentados e pudessem descansar, o que nunca foi o caso, ainda que ninguém os atacasse, ainda assim, pelo menos uma boa parte das pessoas nunca chegaria a seu destino.

Como não aceitar que há provas circunstanciais da intenção genocida do Estado Otomano? É frequente ler que o governo providenciou guardas para acompanhar as caravanas e que deu ordens para que os deportados recebessem proteção. No entanto, sabe-se que os soldados turcos bem treinados e de boa disciplina estavam no front. A guarda providenciada para acompanhar as caravanas era, na verdade, formada por bandidos liberados das cadeias, por ordem do governo.

Também era de conhecimento público que muitos turcos e, principalmente, curdos nutriam forte sentimento anticristão. A guarda das caravanas reunia muitos desses homens, e não é possível que o governo central não tivesse conhecimento desta realidade. Parece pouco provável que tantas falhas logísticas tenham sido reunidas em um plano de ação, sem qualquer intenção de extermínio.

O funcionário alemão Johannes Lepsius, citado pelo embaixador Morgenthau como homem bem informado e para quem Talaat não tinha segredos, ao depor no julgamento de Teilirian em Berlim relatou que:

"oficialmente, afirmou-se sobre as deportações, que se tratava apenas de medidas preventivas, mas particularmente algumas autoridades expressavam claramente que se tratava do extermínio do povo armênio. O que digo aos senhores provém de documentos que publiquei a partir dos autos da embaixada imperial e do Ministério das Relações Exteriores. São principalmente os relatórios dos cônsules alemães no interior e do

${ }^{184}$ Idem. 
embaixador alemão em Constantinopla. (...) A execução das medidas para o extermínio dos armênios foi viabilizada à medida que os Uales, Mutessarifs e Kaimakans, isto é, os chefes superiores, os chefes distritais e os administradores do Conselho, foram colocados a par delas. Os funcionários públicos que se negavam a colaborar eram exonerados. Desse modo, o uale Djelal Paxá, de Aleppo, por exemplo, recusou-se a cumprir as ordens de deportação em sua província. Talaat destituiu-o de seu cargo e o transferiu para Konia. Lá ele agiu do mesmo modo como em Aleppo, protegendo os armênios locais e encarregando-se das deportações. Em consequência disso, foi novamente exonerado e perdeu o cargo." $" 185$

\section{A Organização Especial}

Durante as guerras balcânicas (1912-13), quando o Império Otomano perdeu a posse da cidade de Edirne para os búlgaros, o CUP lançou mão do mesmo grupo de voluntários que haviam lutado em Tripolitania: um destacamento especial do exército, com oficiais bem treinados mas que eram vistos como as tropas que faziam o trabalho "sujo" do Comitê, como os assassinatos políticos, entre outras ações. Esse grupo teve participação importante também dentro do Exército de Ação que restaurou o CUP no poder. Este círculo era muito próximo a Enver, que parecia atuar como seu líder. ${ }^{186}$

Segundo Zurcher, após a tomada de Edirne (março de 1913), Enver enviou alguns desses homens para começar uma guerrilha na Trácia, além do Rio Maritza, território [agora grego] que era, e ainda é, habitado por muçulmanos de língua turca. Esse movimento durou poucos meses mas serviu de 'laboratório' para o movimento de resistência nacional que iria se desenvolver na Anatólia após a Primeira Guerra Mundial. O grupo de oficiais voluntários à volta de Enver parece ter sido conhecido informalmente como Teşkilât-I Mahsusa (Organização Especial) em 1913. Em 1914, a organização foi formalizada com esse nome, sob comando direto de Enver, nesse momento Ministro da Guerra. Durante a Primeira Guerra, o grupo teve papel importante nos bastidores, tanto na repressão aos movimentos separatistas nas províncias árabes, quanto nas campanhas de terror contra os negócios gregos na costa ocidental da Ásia Menor, ${ }^{187}$ como citamos anteriormente.

No caso dos armênios, a Organização Especial foi responsável pela condução das deportações, bem como da guarda das caravanas. Entre suas funções estavam a retirada dos armênios de suas casas e a organização das colunas de marcha, bem como o acompanhamento das caravanas. Uma vez que a maior parte dos soldados regulares estava no front, a

\footnotetext{
$\overline{185}$ Fragmento do depoimento de Johannes Leipsius no julgamento de Salomon Teilirian, apud PASCHOAL, op. cit., p. 119-120.

${ }^{186}$ STODDART, Philip (1963) The Ottoman Government and the Arabs 1911-1918: a preliminary study of Teşkilât-I Masusa, Tese de Ph.D (não publicada), Princeton, fl. 52, apud ZURCHER, op. cit., p. 109.

${ }^{187}$ ZURCHER, idem.
} 
Organização Especial, sob ordens diretas de Enver, escolhia e liberava das cadeias os condenados dispostos a 'ajudar' na condução dessas tarefas.

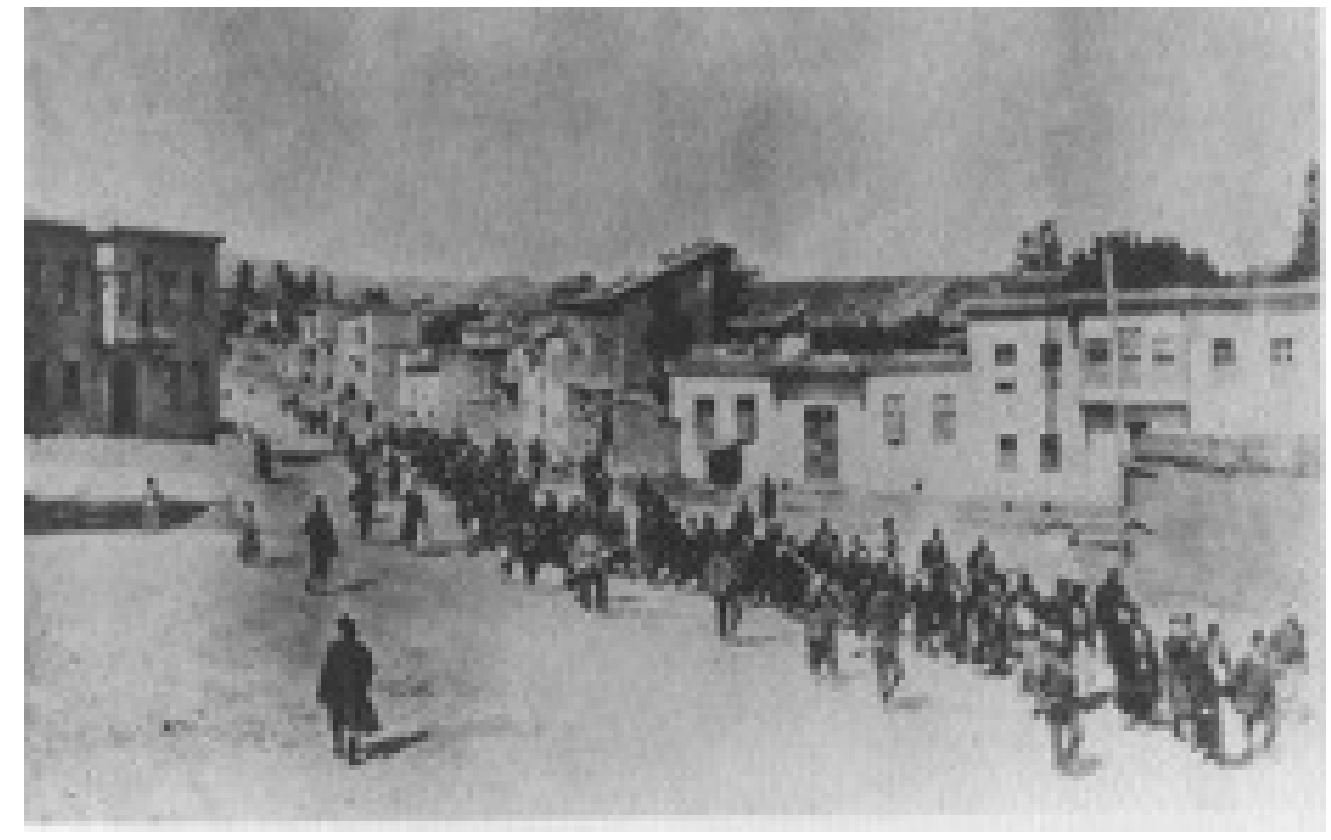

12- Caravana de deportados armênios de Harput sob vigilância armada, maio de 1915. A Fotografia foi tirada por um comerciante alemão, de sua janela. (Cortesia de doador anônimo para o projeto SAVE)

\section{As deportações}

Um resumo (da visão turca) desta operação está disponível no site do Ministério de Relações Exteriores da Turquia:

"Os armênios que viviam na Anatólia Oriental foram transferidos para zonas em outras regiões otomanas, tendo reservados os direitos de voltar a suas casas após o final da guerra. A transferência começou após a necessária preparação. Enquanto isso, os armênios vivendo em áreas fora da zona de operações militares não fizeram parte do processo de reassentamento. Portanto, os armênios de Istambul, Kütahya e Aydin não foram afetados por essa lei. A decisão feita pelo governo otomano não foi uma extensão de uma ideologia.

Nessa lei, todas as medidas foram tomadas para assegurar a segurança dos armênios sujeitos à relocação. O Governo Otomano instruiu as autoridades locais a tomar as necessárias medidas de segurança para uma relocação organizada dos armênios. Mais ainda, oficiais e civis que desobedeceram essas instruções e cometeram ofensas contra os comboios armênios foram julgados pelas Cortes Marciais (Divan-i Harbi Örfi, 19151916). As Cortes decidiram pela prisão de 1673 pessoas e pela pena de morte para 67 indivíduos. Os documentos relativos ao caso estão disponíveis nos Arquivos Otomanos.

Apesar dessas medidas, as condições de guerra, as gangs locais, roubos, sentimentos de ódio e vingança, levaram a ataques aos comboios nas regiões em que a autoridade estatal era relativamente alta. Insuficiência de alimento e outros meios em tempo de guerra, condições climáticas extremas e epidemias como tifo também ajudaram a aumentar o número de perdas de vidas humanas. De fato, o período em questão era um momento em que todas as pessoas da Anatólia partilhavam o mesmo destino. Deve ser 
notado que três milhões de pessoas, a maioria civis muçulmanos, morreram na Anatólia durante a Primeira Grande Guerra. Os que pereceram nas mãos dos bandos Armênios alcançam 524 mil, entre os anos de 1914 e 1922."188

Para uma visão armênia sobre os mesmos acontecimentos, existe farta bibliografia, sendo que a maioria dos autores citados neste estudo descrevem esses momentos com maior ou menor detalhamento, subsidiados também em testemunhos de sobreviventes. Importante lembrar que existem centenas de registros, dentre os quais a fotografia cumpre com o seu papel de testemunho.

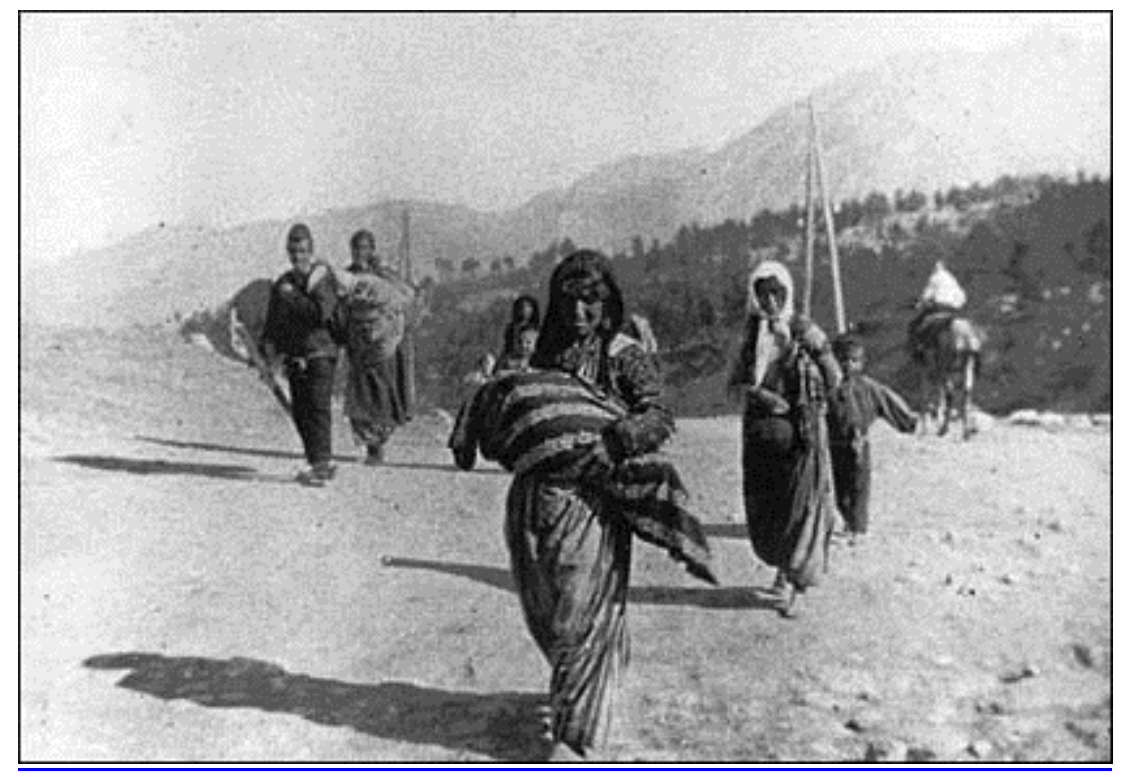

13 - Armênios deportados. Armin T. Wegner Wallstein Verlag, Germany, 1915

Durante o julgamento de Teilirian, que consideramos como uma fonte confiável, uma vez que os testemunhos se fizeram sob juramento, citamos aqui três depoimentos recolhidos, de pessoas muito diferentes, conforme segue:

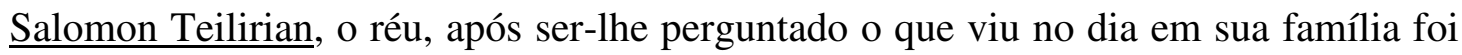
morta, relatou:

"quando a coluna [dos deportados] já havia se afastado um bom trecho da cidade, pediram para parar. Os guardas começaram o saque e tentaram pegar o dinheiro e os abjetos de valor da nossa coluna. (...) Durante o saque abriram fogo na coluna lá da frente. Um dos guardas então agarrou minha irmã, e minha mãe gritou: "que eu fique cega"!". (...) Arrancaram-nos tudo e ainda me bateram. Depois vi partirem o crânio de meu irmão com um machado. (...) ${ }^{189}$-Quando os guardas e os soldados começaram o massacre, o povo também se juntou. Aí partiram o crânio do meu irmão mais novo.

\footnotetext{
${ }^{188} \mathrm{http}: / /$ www.mfa.gov.tr/questions.en.mfa

189 As várias interrupções na narrativa se devem a interrupções do juiz, com questionamentos e também a uma certa aversão do réu a narrar os fatos, pois isso lhe trazia de volta a angústia que sentiu. Ele segue contando porque o juiz o faz ver que é importante para o seu julgamento que o júri conheça todos os detalhes do caso.
} 
Minha mãe caiu. Não sei porque. Talvez um tiro ou alguma outra coisa. (...) Não vi meu pai, ele estava mais à frente, onde também havia luta. (...) Senti uma pancada na cabeça e caí. O que aconteceu depois, não sei. (...) Quanto tempo fiquei lá não sei. Talvez dois dias. Quando acordei, vi à minha volta muitos cadáveres, pois toda a caravana havia sido morta. Vi várias pilhas de cadáveres. Mas não conseguia distinguir muito bem as coisas pois já estava um pouco escuro. Primeiro não sabia onde estava, depois dei pela verdade e vi que eram cadáveres." 190

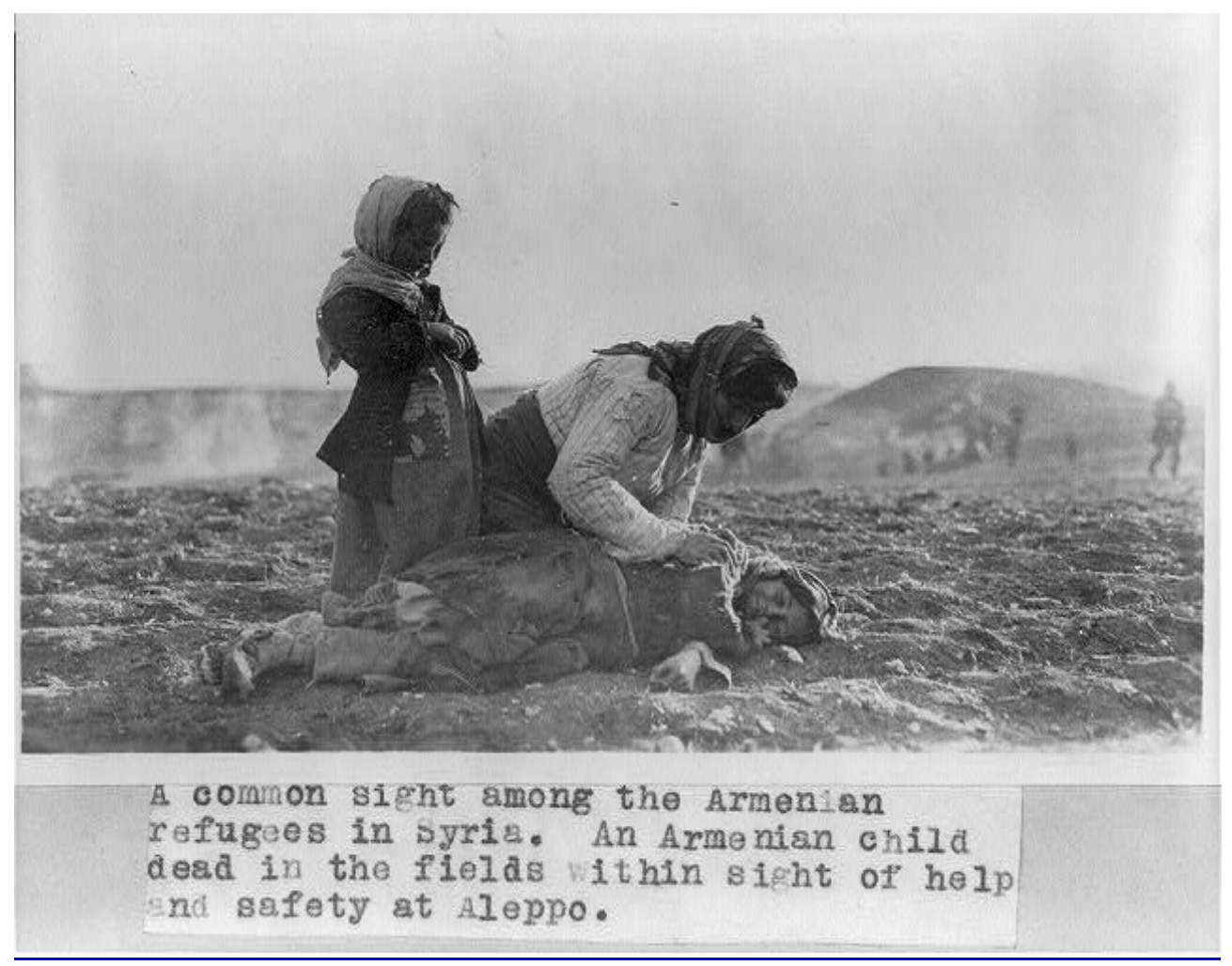

14 - Armênios durante as deportações. Arquivo da Library of Congress Prints and Photographs Division Washington, D.C. 20540 USA, sem data

A testemunha Christine Tersibaschian de 26 anos, ao ser questionada sobre as deportações em Erzerum, sua cidade natal, descreve:

"Em julho de 1915 juntaram os habitantes do lugar e disseram que todos teriam que abandonar a cidade. (...) porque ela fazia parte da zona de guerra e a população civil devia ser evacuada. Os ricos da cidade foram informados oito dias antes, os outros uma hora antes da deportação. Mais tarde soubemos que era uma trapaça e que apenas a população armênia devia ser afastada.

A população foi expulsa em quatro pelotões no decorrer de oito dias. Os que ficaram não ficaram sabendo o que ia acontecendo com as primeiras colunas. Iríamos primeiro para Erzyngian. Eu parti no segundo pelotão. Nossa família compunha-se de vinte e uma pessoas. Só restaram três. No pelotão havia quinhentas famílias. (...) Quando deixamos a cidade e estávamos nos portões da fortaleza de Erzerum, vieram os guardas e procuraram armas. Facas, guarda-chuvas etc. foram arrancados de nós. De Erzurum fomos para Beirburt. Ao passarmos por essa cidade, vimos montes de cadáveres, e tive até de caminhar sobre eles de modo que meus pés ficaram manchados de sangue. (...)

${ }^{90}$ PASCHOAL, op. cit., pp. 39-40. [grifo nosso] 
Depois chegamos em Erzyngian. Prometeram-nos alojamento, mas não tínhamos onde nos abrigar; não nos permitiram beber água. Tivemos até de entregar os bois, e eles foram levados para as montanhas. (...) Quando partimos, separaram dos pelotões quinhentos jovens. Um de meus irmãos também, mas ele conseguiu fugir e voltar. Eu o disfarcei de mulher e ele pode assim ficar comigo. Os outros jovens foram reunidos. (...) Amarraram todos e jogaram dentro da água. Vi com meus próprios olhos. Foram jogados no rio e a correnteza era tão forte que todos os que foram jogados na água foram arrastados por ela. (...) Com o que pudemos carregar nas costas, fomos a Malatia; lá nos levaram à montanha e separaram os homens das mulheres. As mulheres foram afastadas uns dez metros dos homens e puderam ver com os próprios olhos o que aconteceu com eles. Foram mortos a machadadas e jogados na água.

Somente os homens foram mortos dessa forma. Quando escureceu um pouco, chegaram os guardas, escolheram as mulheres e meninas mais bonitas e fizeram delas suas mulheres. (...) Quem não obedecia e não queria ceder, eles transpassavam com a baioneta e escancaravam as pernas. Das mulheres grávidas eles partiam as costelas, arrancavam as crianças e jogavam fora. Eu juro." ${ }^{, 191}$

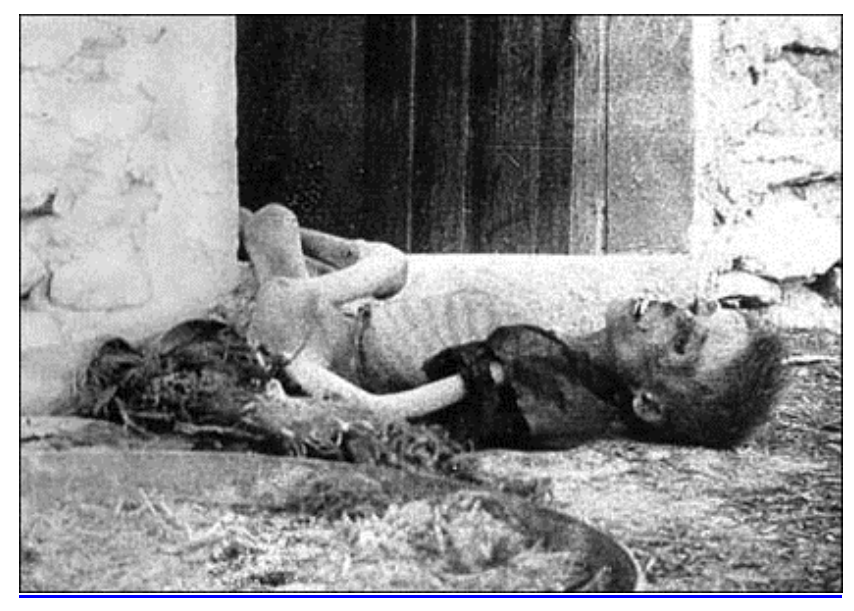

15 - Criança armênia morta de fome. Armin T. Wegner Wallstein Verlag, Germany, 1916

O bispo armênio Krikoris Balakian também relatou a sua história diante do júri:

"No dia 21 de abril de 1915, fui preso pela polícia e expatriado com mais duzentos e oitenta outros intelectuais armênios. Fomos levados de trem durante trinta e seis horas até os arredores de Ankara. Lá, aproximadamente noventa de nosso grupo foram expatriados para Ayasch. Os restantes cento e noventa foram banidos para Tschangere, vinte e quatro horas adiante de Ankara, levados de carroça até lá. Mais tarde, eles foram novamente deportados para Ankara em pequenas caravanas de vinte e cinco, quinze, dez pessoas e ali assassinados. Sobraram apenas dezesseis dessas pessoas. (...) Em Tschangere moravam por volta de duzentos e cinquenta pessoas [armênios] que falavam turco, comerciantes que se mantiveram bem distantes da política. Os dezesseis exilados de Constantinopla deviam ser levados juntos com estes para o deserto Der-el-Zor, por ordem telegráfica do ministro do Interior, em Constantinopla. (...) Quando chegamos a Yosgad, o lugar mais sangrento, vimos nas proximidades, quatro horas adiante, em um vale, algumas cabeças com longos cabelos; eram cabeças de mulheres e meninas. Perguntei ao capitão: tinha ouvido que matavam homens armênios, mas não as mulheres e meninas. "Sim", disse ele, "se matássemos apenas os homens e deixássemos as mulheres e meninas, depois de cinquenta anos haveria novamente alguns milhões de armênios. Por isso temos de matar

PASCHOAL, op. cit., p. 115-116. [grifo nosso] 
também as mulheres e as crianças para que não ocorram nunca mais desordens internas e externas". (...) "Nós matamos todas, mas não na cidade". Era proibido, porque Abdul Hamid em 1895-1896 ordenara matar todos na cidade. Os povos europeus, todo o mundo civilizado, ficaram sabendo disso depois, e não iriam permitir tal coisa. (...) O capitão disse-me: "posso contar-lhe isto tranquilamente porque você vai para o deserto onde morrerá de fome e não terá a oportunidade de trazer à luz esta verdade". ${ }^{192}$

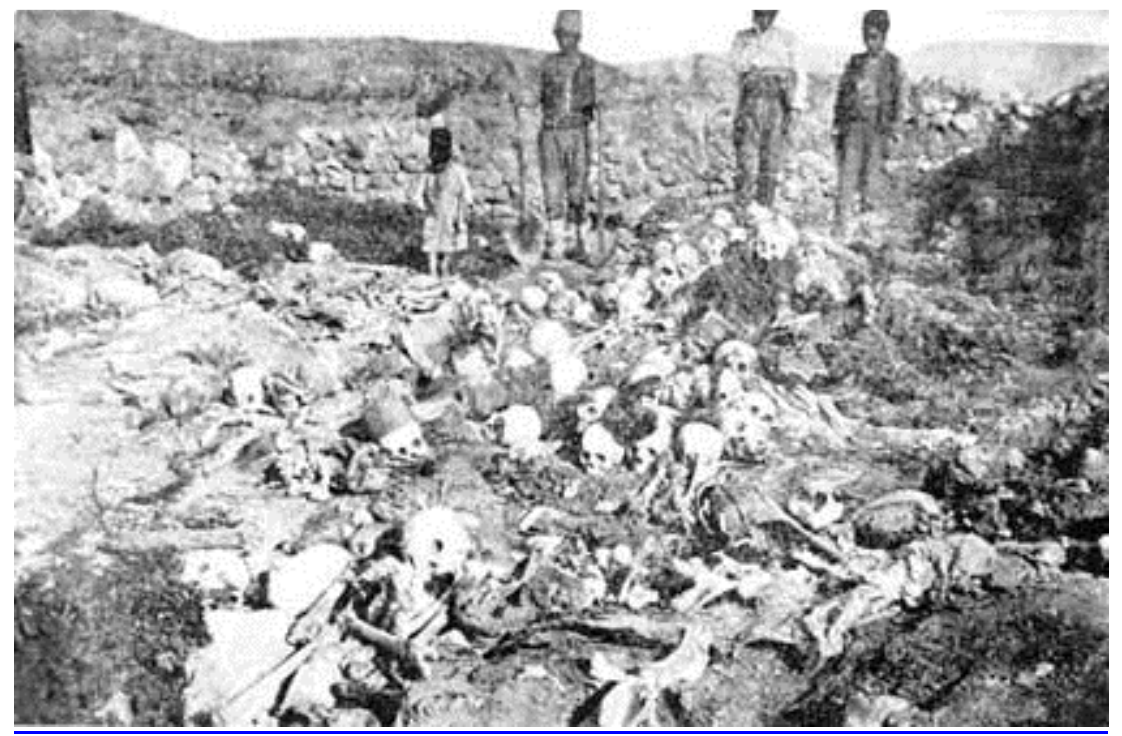

16 - Restos mortais de armênios queimados vivos em carro de boi em Aly-Zrna, s.d. Arquivo do Genocide Museum Yerevan.

Muitos são os autores que reconstituem as atrocidades cometidas durante as deportações. Não pretendemos reproduzir uma a uma essas narrativas, nem as imagens. Consideramos importante fornecer informação ao leitor interessado, para quaisquer pesquisas específicas. Em síntese, as narrativas têm em comum pontos chave:

- a maior parte dos deportados teve pouco tempo para reunir seus pertences e organizar a viagem; muitos foram avisados um dia antes e outros, no próprio momento da retirada;

- os homens válidos era levados em caravanas separadas, antes dos demais e massacrados pouco depois de deixar a cidade, pelos próprios guardas das caravanas ajudados por curdos, algumas vezes também a população turca da vila atacava os deportados;

- as caravanas que levavam mulheres crianças e velhos, ao sair da cidade conduziam carros de boi ou animais de carga, com os pertences dos proprietários, mas em pouco tempo eram saqueadas e todas essas cargas roubadas. Os saques em especial, são muito citados, principalmente buscando o dinheiro e as joias que as famílias possuíssem;

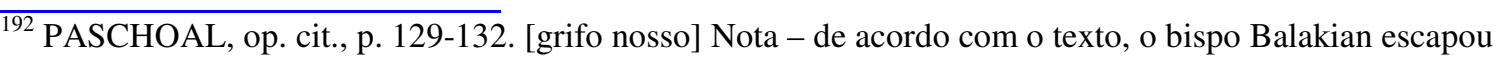
escondendo-se entre engenheiros alemães durante vários meses e depois embarcando em um trem que conduzia soldados alemães para Constantinopla.
} 
- alguns deportados de cidades servidas por ferrovia utilizaram esse meio de transporte pelo menos em uma parte da viagem, mas a grande maioria empreendeu todo o percurso a pé. Muitos relatam que, ao chegar perto de rios ou fontes, os guardas impediam que bebessem ou, em vários casos, cobravam pela água, daqueles que ainda possuíam algum dinheiro escondido;

- há inúmeras referências ao tratamento às mulheres grávidas que davam à luz em marcha, sendo imediatamente forçadas a continuar andando. Há referências de que ao chegar às margens de grandes rios, como o Eufrates, os guardas atiravam as crianças à água, algumas vezes após golpear-lhes as cabeças;

- de cidades como Aleppo, local de reunião dos que logravam sobreviver às marchas, chegam informações de que os habitantes da cidade foram proibidos de oferecer alimento ou mesmo água aos deportados, agrupados em campos fora da cidade, onde as epidemias matavam centenas diariamente. Conforme informações do Consul Rössler, no final de setembro [de 1915] a taxa de mortalidade entre os deportados era de 110 por dia. ${ }^{193}$ Geralmente, após poucos dias nesses campos, os sobreviventes eram novamente enviados em marcha para novo destino, muitas vezes na direção oposta, ou seja, de volta ao ponto de partida. $^{194}$

Existem ainda, em quase todas as obras e sites de internet, fotografias destas marchas, expressivos registros da situação vivenciada pelos deportados. Tais imagens prescindem de explicação: são tão absurdas quanto esclarecedoras, formas explícitas da maldade humana.

\footnotetext{
${ }^{193}$ LEWY, op. cit., p. 193.

${ }^{194}$ Para detalhes sobre as deportações ver: BALAKIAN, pp. 225-275; AKÇAM, pp. 174-193; LEWY, pp. 162208 - LEWY faz um relato em separado de cada grande cidade envolvida no processo; BLOXHAM, pp. 84-93; ZURCHER, pp. 115-126 entre outros.
} 


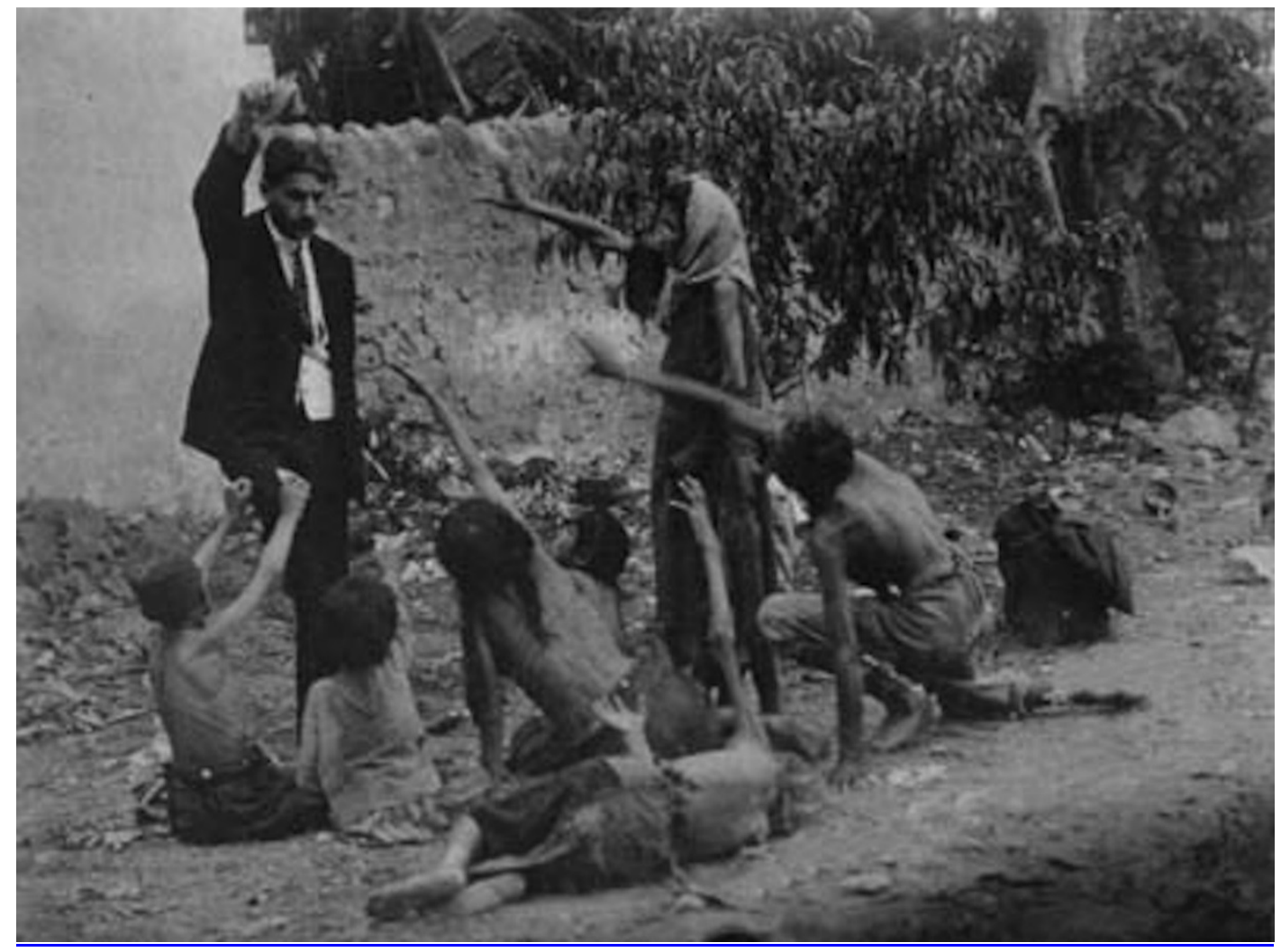

17 - Oficial turco provoca crianças deportadas famintas com um pedaço de pão, 1915 Collection of St. Lazar Mkhitarian Congr.

De modo geral, os autores pró-armênios se estendem em descrições detalhadas das agressões, enfatizando, principalmente, os números de mortos, enquanto os pró-turcos fazem o oposto. Por exemplo, Stanford e Ezel Shaw relatam as deportações em um subcapítulo de módicas três páginas:

(...) "Instruções específicas foram dadas para o exército proteger os armênios contra ataques de nômades e providenciar suficiente comida e outros suprimentos necessários durante a marcha e após o assentamento. Avisos foram enviados aos comandantes militares otomanos para deixar claro que nem os curdos nem outros muçulmanos deviam aproveitar a situação para se vingar dos longos anos de terrorismo armênio. Os armênios deviam ser protegidos e cuidados até que retornassem a suas casas após a guerra. ${ }^{195}$ Uma lei suplementar estabelecia uma comissão especial para anotar as propriedades de alguns deportados e vende-las por preços justos, guardando os valores recebidos em custódia até o seu retorno. Muçulmanos que desejassem ocupar os edifícios abandonados podiam fazê-lo como inquilinos, pagando aluguel ao fundo de custódia e entendendo que deveriam entregar a propriedade aos proprietários originais no seu retorno. (...) Pode-se assumir que por volta de 200 mil morreram como resultado não apenas do transporte mas também das condições de fome, doenças e guerra que mataram cerca de dois milhões de muçulmanos no mesmo momento. Exame cuidadoso dos registros secretos do gabinete otomano daquele tempo não revelam evidência de que os líderes do CUP, ou qualquer

\footnotetext{
$\overline{195}$ BVA, Meclis-i Vükeka Mazbatalari, decisions of May 14/27 and May 17/30, 1331/1915, quoted partly in BAYUR, III/3, Ankara, 1957, pp. 35-40; Düstur2 , VI, p. 609; May 27, 1915; FO 371/9158, 4376/P.I.O. 206 apud SHAW, op. cit., p. 315.
} 
outra pessoa do governo central, ordenaram o massacre. Ao contrário, as ordens eram às autoridades locais para prevenir qualquer tipo de ataque e distúrbios comunais que pudessem causar perda de vidas." 196

Por fim, reproduzimos o texto do telegrama do Embaixador Morgenthau ao Secretário de Estado em Washington, em 16 de Julho de 1915:

"858, 16 Julho 1pm. Confidencial. Você recebeu meu 841? Deportações e excessos contra armênios pacíficos estão aumentando e de angustiantes relatos de testemunhas parece que uma campanha de extermínio de raça está em progresso sob pretexto de represália contra rebelião. Protestos, bem como ameaças são inúteis e provavelmente incitariam o governo otomano a medidas mais drásticas já que eles estão determinados a negar a responsabilidade por sua absoluta negligência às capitulações e eu acredito que nada menor que força de fato o que obviamente os Estados Unidos não estão em posição de exercer iria resolver adequadamente a situação. Sugiro que você informe os países beligerantes e missões sobre isso. (assinado) Embaixador Americano, Constantinopla."197

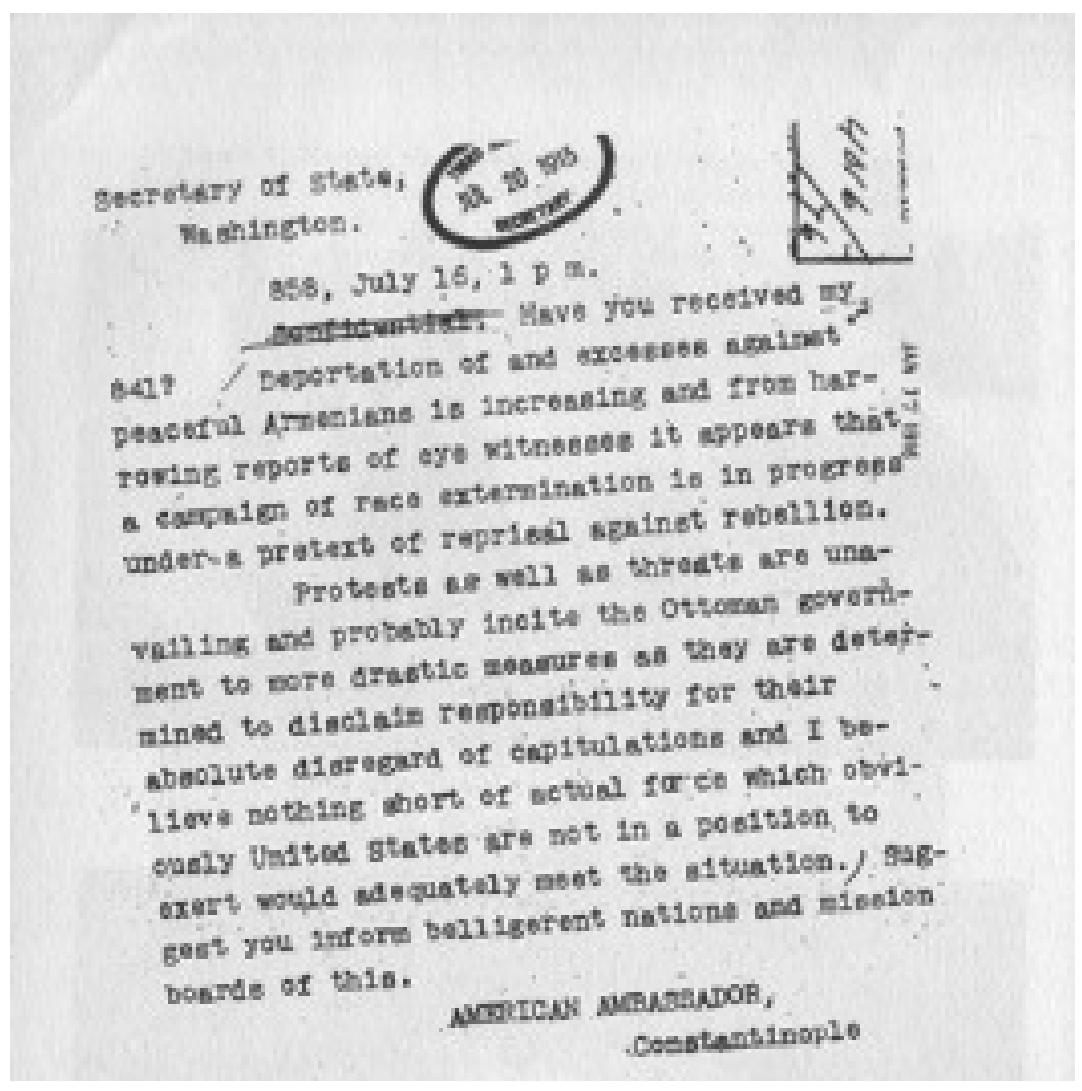

18 - Telegrama do embaixador americano Morgenthau ao Secretário de Estado, 16 de julho de 1915, National Archives, State Deptartment, Record Group 59.867.4016/76.

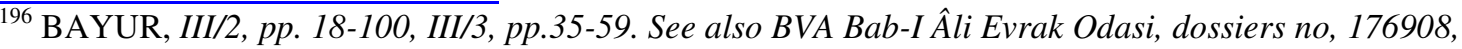
189354, 196578, 203987 and 148765, and FO 2130/1 1985, FO 2488/108070; HOVANNISIAN, Road to Independence, pp. 48-55 apud SHAW, op. cit., p. 315.

197 Do Arquivo Nacional, Departamento de Estado, Record Group 59.867.4016/76, apud BALAKIAN, op. cit., p. 232-233.
} 
O Embaixador Morgenthau é citado por muitos autores como um dos homens que lutaram para levar o massacre dos cristãos da Anatólia ao conhecimento do mundo. Em suas memórias, o embaixador cita várias visitas a Talaat e Enver para tratar do assunto 'armênios', todas sem sucesso, muitas terminando em acessos de raiva dos líderes turcos. Em uma delas, o diplomata descreve a sua indignação ao receber o seguinte pedido de Talaat:

“"Eu gostaria', Talaat disse, 'que você pedisse às companhias de seguro americanas que nos mandassem uma lista completa dos armênios que mantém $\underline{\text { seguros com eles. Eles estão praticamente todos mortos agora e não têm herdeiros }}$ para receber o dinheiro. Isso é claro, reverte para o Estado. O Governo é o beneficiário agora. Você pode fazer isso?'Isso foi demais para mim e perdi a calma. 'Você não terá essa lista de mim' eu disse, e me levantei e o deixei.",198

\subsection{3 - Fim da Guerra, fim do CUP}

O curso da guerra deixou os "Jovens Turcos" em uma situação muito grave. Os oficiais alemães pressionavam por resultados que o exército turco não tinha a menor condição de alcançar. Desde o início as forças turcas sofreram dissabores e salvo alguns dias melhores, como a vitória em Gallipolli, não teve grandes sucessos durante toda a guerra. O país inteiro sofria com as condições do conflito, mesmo sem citar o destino dos armênios. De fato, como frisam vários autores pró-turcos, milhares de muçulmanos também morreram durante os anos de guerra, principalmente de fome, frio e doenças. Tudo isso devido à falta de preparo do país para abraçar uma causa tão imensa.

Na verdade, o Império Otomano estava em guerra desde 1897, com breves intervalos. Em 1914, quando começou a Grande Guerra, restava pouco do exército para oferecer qualquer resistência. Ainda assim, os motivos políticos se sobrepuseram aos humanos e, com uma boa dose de pressão alemã, os jovens líderes do CUP optaram por enfrentar esse desafio. ${ }^{199}$ Talvez porque a cortina providenciada pela guerra, com a saída dos diplomatas estrangeiros, parecesse o disfarce ideal para o plano que já tinham em mente, ou talvez, simplesmente, porque a diplomacia alemã superava a turca com alguma folga. O fato é que o império não teve outra alternativa além de aceitar a guerra, depois que os alemães fecharam os Dardanelos em 27 de Setembro de 1914.

\footnotetext{
$\overline{198}$ MORGENTHAU, op. cit., p. 339. [grifo nosso]

199 MORGENTHAU dedica vários capítulos de suas memórias a explicar como e porque os alemães praticamente empurraram o Império Otomano à guerra. Para detalhes ver MORGENTHAU, op. cit., p. 68-129.
} 
As pressões só aumentavam, de todos os lados, e os jovens líderes do Comitê precisariam de muito mais tempo para resolver todos os problemas do país que governavam. Mas, para alívio dos cristãos, o tempo não foi suficiente. Quando as informações sobre o tratamento ministrados aos deportados começaram a ganhar as manchetes da grande imprensa internacional, e os olhos escandalizados começaram a voltar-se na direção do Oriente, o governo otomano iniciou uma 'campanha' para parar as deportações.

Segundo Lewy, a partir do final de Agosto de 1915, o governo central enviou repetidas ordens para que nenhum armênio fosse mais deportado. Essas ordens aparentemente, não eram obedecidas, pois foram expedidos vários decretos seguidos nesse sentido. ${ }^{200}$ Respondendo às exigências diplomáticas de seus aliados, Talaat, Ministro do Interior e homem mais poderoso do Império, afirmou algumas vezes aos embaixadores Pallavicini, da Áustria e Metternich, da Alemanha, que havia tomado "medidas amplas" para a alimentação dos deportados e que as ofensas contra propriedades armênias estavam sendo severamente punidas. ${ }^{201}$ Entretanto, como se sabe, isso não condiz com a realidade. As ordens telegráficas de Talaat para finalizar as deportações, essas sim, foram autenticadas e, inclusive, mostradas aos embaixadores. Porém é, no mínimo, curioso que o homem conhecido como o mais importante da Turquia visse suas ordens serem descumpridas repetidamente e não perdesse o bom humor. Durante as entrevistas com Morgenthau, Talaat sempre se mostrou muito zeloso de sua posição de líder máximo ${ }^{202}$. Como seria possível que alguém ousasse descumprir suas ordens simplesmente? Talvez porque esses telegramas fossem apenas uma fachada para "mostrar aos alemães", seguidos imediatamente de contraordens confidenciais. Além disso, as ordens expedidas continham especificações como "nenhum armênio deve ser deportado, a menos que tenha ligação com os revolucionários Dashnaks". A exceção para os 'perigosos revolucionários' abria uma nova janela para excessos dos oficiais subalternos, como ressalta Lewy. ${ }^{203}$ Oficialmente, as deportações cessaram no final de 1916 e já não mais ocorriam quando Talaat ascendeu ao posto de Grão Vizir, em 4 de fevereiro de 1917. Neste momento, afirmou ao embaixador alemão Kühlmann sua intenção de seguir uma política de igualdade de todas as nacionalidades no estado Otomano. ${ }^{204}$

\footnotetext{
${ }^{200}$ LEWY, op. cit., p. 205.

${ }^{201}$ LEWY, op. cit., p. 206.

${ }^{202}$ MORGENTHAU, op. cit., p. 143 e outras - o embaixador americano em diversas ocasiões se utilizou da vaidade do ministro Talaat para conseguir alguma providência de sua parte 'para mostrar a seus colegas que suas ordens tinham mais valor'

${ }^{203}$ LEWY, op. cit., p. 207.

${ }^{204}$ Kühlmann to Berlin, February 16 and 24, 1917, PA, T. 183/46/A5919 and A6742 (fiche 7162), apud LEWY, idem.
} 
A partir desta data, começam as contagens de número de vítimas. Os números são muito díspares, de acordo com o autor consultado, como se nota na tabela montada por Lewy:

\begin{tabular}{|l|r|}
\hline \multicolumn{1}{|c|}{ Fonte } & Número de vítimas \\
\hline Halacoglu (2002) & 56.612 \\
\hline Ötke (1989) & 600.000 \\
\hline Zurcher (1997) & 700.000 \\
\hline Morgenthau (1918) & 800.000 \\
\hline Ministério do Interior Otomano(1919) & 800.000 \\
\hline Lepsius(1919) & 1.000 .000 \\
\hline Dadrian (1999) & 1.350 .000 \\
\hline Karajian (1972) & 2.070 .037 \\
\hline
\end{tabular}

Fonte: LEWY, op. cit., p. 240.

A diferença pode ser explicada pelo desconhecimento do número exato de habitantes armênios no Império Otomano antes da deportação, o que compromete o cálculo da diferença. O governo turco sempre utiliza esses dados para provar a 'inocência' dos "Jovens Turcos". Alega que não é possível precisar quantos armênios morreram em consequência das marchas ou dos ataques, pois, um grande número morreu em consequência da fome e das doenças, assim como aconteceu com os muçulmanos.

Grande parte dos estudos aqui citados termina a descrição histórica do episódio - seja ele 'genocídio', 'massacre' ou 'subproduto da guerra' - ao final das deportações em 1916. É como se depois desse ano, o tempo tivesse parado. Mas, apesar de reduzidas, em comparação com os números assombrosos dos anos selvagens de 1915 e 1916, essas deportações seguiram acontecendo até 1923, em vários lugares do Império, incluindo também os gregos e outros cristãos. 


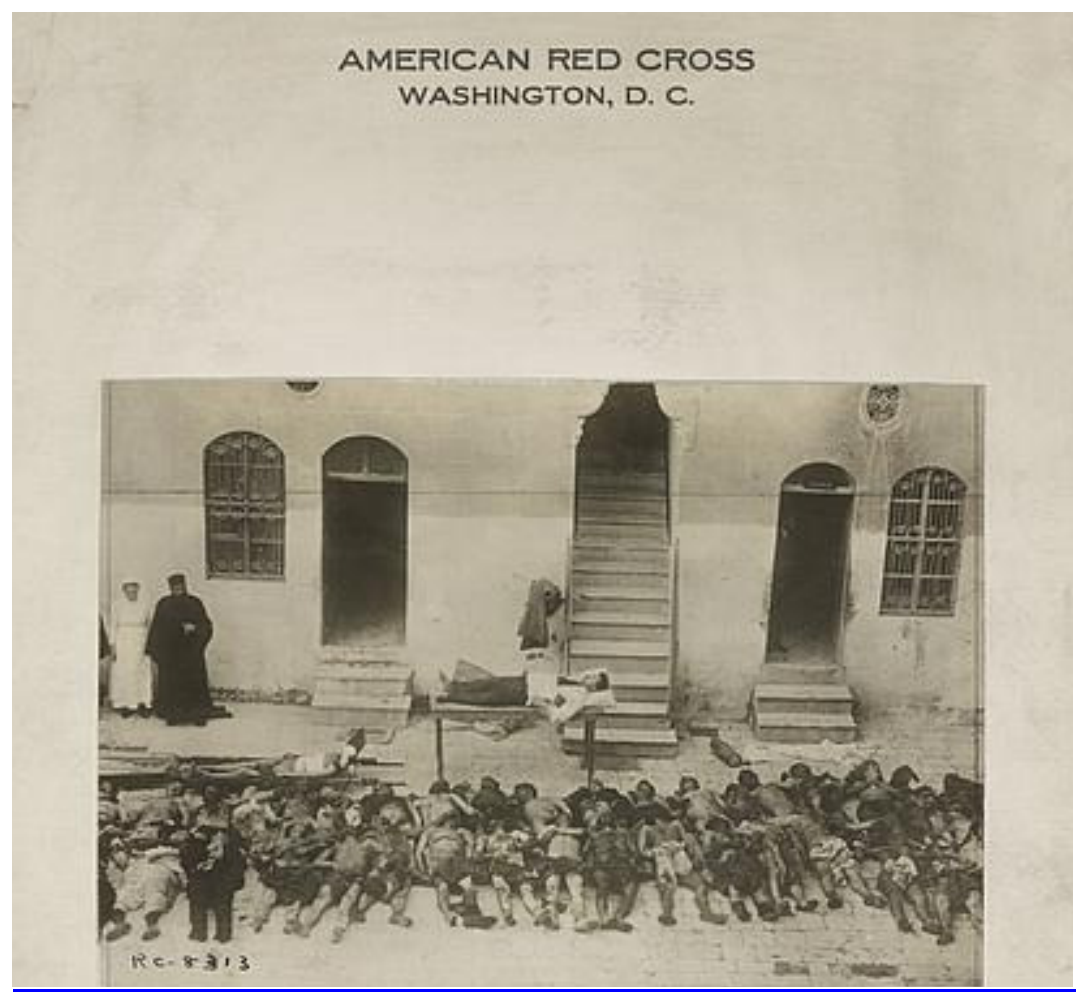

19 - Quarenta armênios mortos em massacre na Ásia Menor, fevereiro de 1919. Arquivo da Library of Congress Prints and Photographs Division Washington, D.C. 20540, USA

É possível que essa lacuna de informação se deva à preocupação desses autores em provar ou negar legalmente o crime de genocídio. Por conta disso, debruçam-se em detalhes e deixam de lado o fenômeno como um todo. Em nossa opinião, é possível perceber a intenção do governo turco de 'livrar-se dos grupos incômodos', tomando a distância necessária para visualizar o quadro das ocorrências enquanto um conjunto de ações planejadas.

Fica evidente que o ano de 1917 foi decisivo para o desfecho da guerra, embora este ainda demorasse. Em março, a Revolução Russa derrubou o Tzar e em abril os Estados Unidos entraram na guerra junto aos Aliados, seguido pela Grécia, em junho ${ }^{205}$. Esse último fato, longamente esperado e igualmente temido pelos líderes otomanos, moveu as últimas forças do Império, em uma reação quase visceral ao inimigo odiado por tantos anos. Havia motivo para temer a entrada da Grécia ao lado da Inglaterra pois, em muitas ocasiões, os gregos haviam sido auxiliados e apoiados pelo governo britânico que tinha interesse em 
manter uma base sólida no Mediterrâneo. E também porque o apoio popular ao irredentismo grego era forte nesse momento. ${ }^{206}$

Durante três anos, o Rei Constantino I, cunhado do Kaiser alemão, conseguiu manter a Grécia na neutralidade, apesar dos esforços em contrário de Eleftérios Venizelos, Primeiro Ministro grego. A divergência entre esses dois poderes acabou por dividir de fato o país, em 1915, no Cisma Nacional. Durante dois anos, o país ficou dividido em dois governos, mantendo a decisão real pela neutralidade, que favorecia os planos do Eixo. Em junho de 1917, tropas francesas e inglesas ocuparam Pireus, o principal porto de Atenas e bombardearam a cidade, exigindo a renúncia do rei. Constantino renunciou e deixou o país a caro de seu filho Alexandre. Um mês depois, a Grécia declarou-se oficialmente em guerra contra o Eixo. ${ }^{207}$

Durante as negociações para esse apoio, a Inglaterra ofereceu a Venizelos a tão almejada Esmirna, após o fim da guerra, promessa que foi cobrada mais tarde. A entrada da Grécia na guerra provocou ainda mais o ódio popular contra os cristãos e desencadeou nova onda de ataques ${ }^{208}$, que entretanto, não tiveram repercussão internacional. Os diplomatas americanos, principais responsáveis pelas comunicações entre o interior do Império Otomano e o resto do mundo, já haviam sido forçados a deixar o país.

Durante o ano de 1918, a decadência do exército turco se fazia cada vez mais notória. Em setembro, uma dupla ofensiva aliada, na Macedônia e na Palestina, fez caírem por terra as últimas resistências otomanas. O exército otomano contabilizava mais de 400 mil deserções; a fome e as doenças cobravam vidas diariamente. A situação econômica, que já era desesperadora no início da guerra, havia piorado muito com as deportações porque os grandes bancos e negócios estavam nas mãos dos armênios e gregos, muitos dos quais mortos nesse período.

Em 5 de outubro, o Grão Vizir Talaat Pasha pediu um armistício. Ao não receber resposta e vendo que as tropas francesas e inglesas continuavam ganhando terreno na Macedônia, Talaat renunciou, sendo substituído por Ahmet Pasha, cujo gabinete não incluía nenhum dos antigos líderes do CUP. O novo governo fez novo pedido de armistício e, em 26 de outubro, reuniu-se com o Admiral Calthorpe, em seu navio, ancorado no porto de

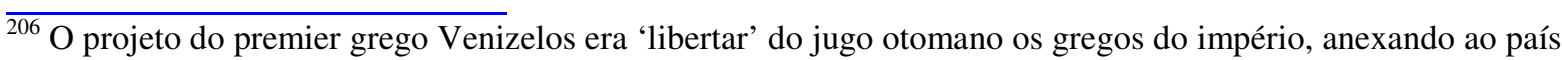
as terras otomanas necessárias para isso, em especial a rica região de Aydin, cuja capital Esmirna era o maior porto otomano e a segunda maior cidade do império.

${ }^{207}$ ABBOTT, George Frederick. Greece and the Allies 1914-1922. Livro de domínio público, disponível para download em http://www.amazon.com/kindle_edition . location 2519 kindle fire reader

${ }^{208}$ A informação desses massacres vem de depoimentos de familiares de sobreviventes, principalmente gregos, colhidos informalmente aqui no Brasil, mas as datas não são precisas.
} 
Moudros, na ilha grega de Lemnos. Apenas quatro dias mais tarde, a delegação otomana retornou a Esmirna e conseguiu, via telégrafo, autorização do gabinete para a assinatura do armistício. Os pontos discutidos durante esses quatro dias referiam-se principalmente a três grandes preocupações dos otomanos:

- que a ocupação dos estreitos, uma vez que inevitável, fosse realizada apenas por tropas inglesas e francesas (sem a participação de italianos e ainda menos de gregos);

- que Istambul não fosse ocupada;

- os artigos 7 e 24 tratavam do direito dos aliados de interferir caso a população estivesse em perigo ou em caso de distúrbios nas províncias armênias. Isso, do ponto de vista otomano, abria a possibilidade para os Gregos e Armênios provocarem a intervenção aliada, por isso, Rauf Bey, representante otomano, pediu que esses artigos fossem mantidos em segredo, o que foi negado ${ }^{209}$;

Finalmente, a delegação otomana pediu que nenhuma tropa grega fosse autorizada a desembarcar nem em Istambul, nem em Esmirna. ${ }^{210}$

O armistício foi assinado em 30 de outubro e, na noite de 1 de novembro, um submarino alemão serviu de veículo para a fuga dos três grandes líderes do Comitê, Talaat, Enver e Djemal, para a cidade de Odessa. O gabinete recém-empossado, que ainda tinha em seus quadros alguns unionistas, foi acusado de facilitar a fuga. Antes de fugir, entretanto, Enver e Talaat estiveram ocupados enviando a Odessa oficiais da Organização Especial, bem treinados e com armamentos, numa preparação para a resistência que viria em seguida ${ }^{211}$.

\footnotetext{
${ }^{209}$ The Turkish source on the negotiations is the serialized version of Rauf [Orbay]'s memoirs, published inYakn Tarihimiz, Ankara: Türkpetrol, n.d, volume 1, p. 5; volume 2, p. 16-18; 48-50; 80-82. [Our Recent History]. ZÜRCHER, Erik Jan The Ottoman Empire and the Armistice of Moudros. Fonte de Internet: http://www.transanatolie.com/english/turkey/turks/ottomans/liddle.pdf ${ }^{210}$ Text in Yakn Tarihimiz, Vol. 2, p. 49 ZÜRCHER, Erik Jan The Ottoman Empire and the Armistice of Moudros. Fonte de Internet: http://www.transanatolie.com/english/turkey/turks/ottomans/liddle.pdf ${ }^{211}$ ZURCHER, op. cit., p. 136.
} 


\section{3 - Mustafa Kemal e os nacionalistas}

Após a fuga dos líderes do CUP, fez-se um vácuo de poder, preenchido vagamente por 20 - Mustafa Kemal (Atatürk) governantes de pouca expressão histórica. Nesse momento, destaca-se a figura de Mustafa Kemal, mais tarde chamado de Atatürk (pai dos turcos), futuro fundador da República da Turquia. Procuramos descrever a seguir o papel deste novo líder na persistência dos atos de intolerância que culminaram com mais massacres e ao final a expulsão de milhões de cristãos do Estado otomano, até 1923.

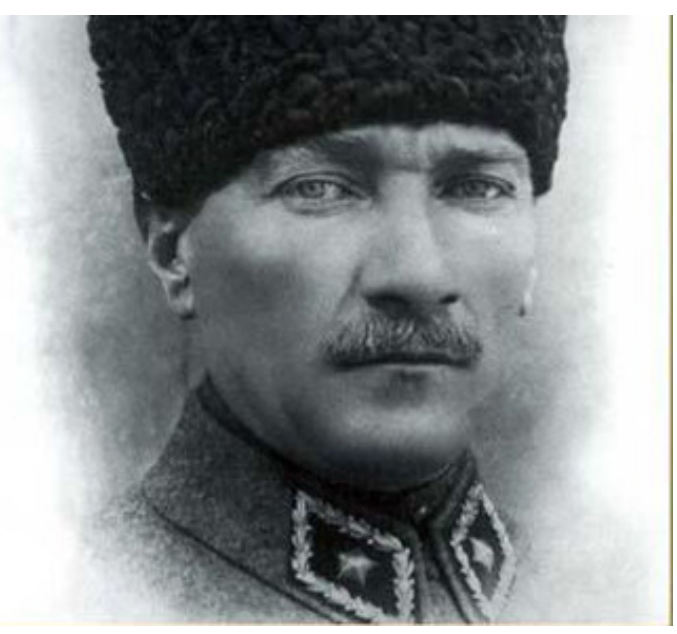

Mustafa Kemal nasceu em Thessalônica em 1881 e aos doze anos ingressou no colégio militar em Istambul. Em 1906 participava de uma célula do movimento dos "Jovens Turcos" na Síria, mas logo retornou a Thessalônica, onde atuou ao lado dos futuros líderes do CUP na preparação para o golpe. Em 1909, teve ativa participação na marcha do Exército de Ação a Istambul, para recolocar o Comitê no posto mais alto do governo ${ }^{212}$.

Ao invés de ocupar um cargo no governo do CUP, sob a liderança de Enver, Talaat e Djemal, Kemal dedicou-se à vida militar. Foi voluntário para integrar o grupo de oficiais que liderou a resistência aos italianos em Tripolitânia, em 1909. Foi durante essa aventura, segundo seu biógrafo Andrew Mango, que Kemal e Enver começaram uma rivalidade ${ }^{213}$ que teria finalmente afastado Kemal dos altos postos de governo do CUP, fato que lhe permitiu seguir com o movimento nacionalista após a queda e a perseguição aos líderes unionistas. Aliás, de acordo com Akçam, nenhum nacionalista queria ser identificado com os unionistas $^{214}$. Não desejavam associar-se às atrocidades ocorridas durante a guerra e ao

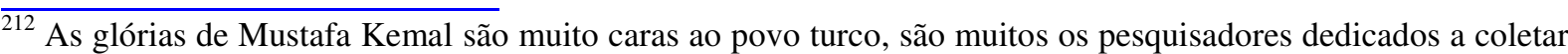
dados biográficos desse grande herói nacional. Entretanto, em inúmeras obras, o líder político é visto com um misto de fervor religioso e orgulho racial, o que faz delas obras pouco confiáveis para compreender o homem de fato. Muitos autores gostam de afirmar, por exemplo, que Kemal teve papel primordial na revolução constitucional turca, quando na verdade sua participação foi marginal.

${ }^{213}$ MANGO, op. cit., p. 105.

${ }^{214}$ Diferenciam-se os 'unionistas', os que faziam parte do Comitê de União e Progresso (CUP) dos 'nacionalistas', os que lutaram na chamada Guerra de Independência, ou Greco-Turca e seguiram com as reformas que transformaram o Império Otomano na República Turca. Embora sejam grupos distintos, muitos nacionalistas eram ou haviam sido unionistas, embora procurassem esconder isso para livrar-se das acusações dos massacres que pesaram sobre os líderes do CUP.
} 
genocídio armênio. Mas, na verdade, a grande maioria dos líderes do movimento nacionalista turco, inclusive Mustafa Kemal, eram antigos membros ou simpatizantes do CUP. ${ }^{215}$

Suas convicções a respeito da Grande Guerra não eram claras a princípio. ${ }^{216}$ No início do conflito, Kemal atuava como adido militar em Sofia e chegou a Istambul apenas em janeiro de 1915, portanto após a fatídica expedição de Sarikamiş, descrita pelo biógrafo Mango como um completo desastre: frio, despreparo e falta de vestuário adequado das tropas otomanas - a ofensiva teria sido iniciada em meio a uma nevasca, com temperaturas de $-26^{\circ} \mathrm{C}$. Mango não cita qualquer intervenção de traidores armênios que tivesse auxiliado essa derrota. $^{217}$

Ao chegar, Kemal foi designado comandante da $19^{\mathrm{a}}$ divisão, regimento que estava por ser formado para defender a costa norte do Mar de Mármara, região próxima aos Dardanelos, na península de Gallipolli. Sua atuação à frente da $19^{\mathrm{a}}$ divisão durante a campanha de Gallipolli (abril/1915 - janeiro/1916) lhe rendeu várias condecorações e uma duradoura fama de herói de guerra. Juntamente com isso, Kemal conseguiu aumentar suas diferenças com Enver e desagradar o Comandante alemão Liman von Sanders, com sua franca oposição ao envolvimento e à interferência alemã no exército otomano. ${ }^{218}$

Após desentendimentos com os alemães, Kemal transferiu-se para outras partes do front, onde teve oportunidade de desenvolver e demonstrar seus dotes como estrategista militar. As tropas o respeitavam e seguiam incondicionalmente. No momento da rendição do Império Otomano, Kemal encontrava-se em Adana e, como outros comandantes otomanos, surpreendeu-se com a continuação da ocupação aliada no Império após a assinatura do armistício. O texto do Armistício de Moudros determina que os aliados teriam direito de ocupar qualquer região do império otomano se houvesse ameaça à população. Entretanto, como 'ameaça' é um termo bastante amplo, os aliados sentiram-se à vontade para ocupar vários pontos - de interesse, é claro - utilizando esse argumento. Mosul foi ocupada em 1 de novembro pelos britânicos e poucos dias depois, Kemal enfrentou um dilema na Síria, quando os ingleses o notificaram que pretendiam ocupar também Iskenderum, pois precisavam do porto para suprir as tropas em Aleppo.

Ao opor-se à ocupação, Kemal se tornou persona non grata ao novo gabinete, que aboliu o regimento sob seu comando e o chamou de volta a Istambul. O grão vizir Ahmet Izzet Pasha enviou a ele um telegrama com a seguinte constatação: "devemos ter em mente

\footnotetext{
${ }^{215}$ AKÇAM, op. cit., p. 304.

${ }^{216}$ MANGO, op. cit., p. 137.

${ }^{217}$ Idem, p. 141.

${ }^{218}$ Ibidem, p. 156.
} 
que estamos sem forças e devemos falar e agir de acordo"219. Essa declaração teria enfurecido Kemal, mas nesse momento seus esforços de resistência não encontraram apoio: o povo não estava pronto para reagir.

Mango considera que problemas ocorreram quando as tropas francesas, ao ocupar Adana, trouxeram consigo voluntários armênios e que vários deles haviam sido deportados para a Síria em 1915 e retornaram, retomando suas antigas propriedades e tentando vingar-se dos vizinhos turcos. Não teria sido a ocupação militar europeia e sim a possibilidade de perder o país para a minorias cristãs, o que afinal levantou a resistência popular. ${ }^{220}$

Kemal voltou a Istambul por poucos meses, mas estava lá quando os aliados ocuparam a cidade. Tropas inglesas, francesas e italianas disputavam poder nas ruas e não se preocupavam em ser gentis com os moradores. Os italianos, segundo Mango, eram os mais corteses. Em um acordo secreto assinado em Londres em 1915, os italianos haviam recebido a promessa de "uma porção justa de terras na região mediterrânea da província de Adalia" por seus préstimos durante a guerra. Essa justa porção foi, mais tarde, ampliada para incluir as cidades de Esmirna e Konia ${ }^{221}$. Sabiam, é claro, que a Grécia também exigiria o mesmo quinhão e isso levava os italianos a tentar uma aproximação diplomática e cordial com os turcos.

Com a ocupação aliada em Constantinopla e o início da 'caça às bruxas' contra os membros do CUP, grande parte dos membros remanescentes do comitê fugiu ou passou a viver na clandestinidade, planejando os próximos golpes. Uma nova organização secreta foi formada, com os mesmos membros e nos mesmos moldes da Organização Especial de Enver, chamada "Karakol", cujo líder era o unionista Kara Kemal. Estes homens contavam com o apoio de Talaat e Enver e estavam em contato com Mustafa Kemal em Istambul, onde já ganhava força o movimento revolucionário. A ideia da clandestinidade lhes agradava, já que muitos haviam sido responsáveis pelo terror contra os gregos e armênios e temiam ir a julgamento $^{222}$. Muitos foram presos no final de janeiro de 1919 e Mustafa provavelmente escapou da prisão por ter muito prestígio junto ao exército, além de apoio italiano. No entanto, alguns de seus amigos foram deportados para Malta sob custódia britânica.

De acordo com Hofmann, imediatamente após o armistício, irromperam grupos espontâneos de resistência contra os vitoriosos Aliados. Em muitas regiões se formaram 'Comitês em Defesa dos Direitos Nacionais', fundados por ordem direta de Talaat e Enver ou

\footnotetext{
${ }^{219}$ MANGO, op. cit., p. 193.

${ }^{220}$ Idem

${ }^{221}$ Ibidem, p. 197.

${ }^{222}$ ZURCHER op. cit., p. 135.
} 
por iniciativa da Karakol. Estes conclamavam a população muçulmana a resistir a ocupação aliada e qualquer divisão dos territórios otomanos, bem como a repatriação dos refugiados cristãos e deportados sobreviventes. Uma vez que muitos muçulmanos haviam estado envolvidos em crimes contra armênios, gregos ou sírios, eles temiam ser acusados legalmente. Além disso, vários muçulmanos anteciparam o mesmo destino de expulsão e expropriação, como os armênios e gregos já haviam feito antes. Portanto grupos armados de partisans antialiados surgiram, com muitas adesões dos desertores do exército otomano. ${ }^{223}$

A ocupação da capital otomana pelos Aliados ocasionou também uma fuga dos oficiais e parlamentares. Os mais engajados no movimento revolucionário foram para o interior da Anatólia, lugar de difícil acesso para as tropas aliadas. Diante da necessidade de um nome para liderar o movimento, contataram primeiro o antigo Grão Vizir, Ahmed Izzet Pasha, um ardente nacionalista. Após a sua recusa, os líderes da Karakol procuraram Mustafa Kemal. $^{224225}$

No início de 1919, as notícias sobre um possível desembarque de tropas gregas em Esmirna se espalharam por todo o império, causando uma onda de repulsa. As tensões existentes entre as comunidades muçulmanas e cristãs já haviam voltado a crescer, chegando a massacres pontuais em algumas cidades, principalmente na costa do Mar Negro, na região conhecida como 'Pontus, ${ }^{226}$, onde a população grega ainda era considerável. Em Giresun, as autoridades locais empregaram contra os gregos um notório bandido chamado Topal Osman, que aterrorizou a população da cidade, em especial os gregos, mas também armênios e, até mesmo, turcos. ${ }^{227}$

Embora pareça natural que a consciência antigrega tenha aumentado ao ser anunciado o desembarque, esta informação foi ventilada apenas em fevereiro de 1919 e publicada em dezembro de 1918, pelo New York Times:

"as autoridades turcas, apesar da derrota turca, estão prosseguindo com a atitude brutal em relação às populações cristãs do império e estão incitando o povo otomano a ataques

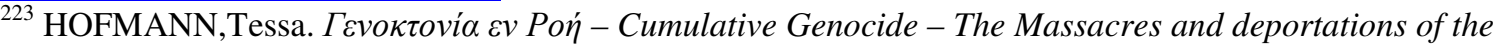
Greek Population of the Ottoman Empire (1912-1923) in HOFMANN, Tessa; BJORNLUND, Matthias; MEICHANETSIDIS, Vasileios. The Genocide of Ottoman Greeks - Studies on the State-Sponsored Campaign of Extermination of the Christians of Asia Minor, 1912-1922 and its Aftermath: History, Law, Memory. New York, Melissa International Ltd, 2011, p. 65.

${ }^{224}$ CRISS, N. Bilge. Istanbul under allied occupation 1918-1923. Leiden, E.J. Brill, 1999, p 100 apud ZURCHER, op. cit., p. 142.

${ }^{225}$ Neste episódio, mais uma vez, pode perceber o quanto Kemal se tornou um herói mítico - grande parte dos autores colocam Kemal como o precursor e idealizador do movimento nacionalista, quando na verdade ele foi escolhido como líder muito mais tarde.

${ }^{226}$ Encontrada também na literatura como Ponto, Ponto Euxino.

${ }^{227}$ MANGO, op. cit., p 213.
} 
fanáticos contra os não-muçulmanos (...) Muitos sinais de organização entre os turcos para novos massacres de cristãos, e particularmente gregos, são notados". ${ }^{228}$

Kemal foi enviado pelo Sultão à cidade de Samsun, na costa do Mar Negro, como inspetor do $9^{\circ}$ regimento, devendo restabelecer a ordem na região e investigar as notícias de que o exército estivesse auxiliando a formação de "conselhos" e, se fosse verdade, acabar com essa prática. Ele chegou a Samsun em 19 de Maio, quatro dias após o desembarque grego em Esmirna. No dia seguinte enviou telegrama ao Grão Vizir Damat Ferit em que falava da indignação do povo e do exército diante desse ato e da certeza de que o governo faria o necessário para defender os interesses nacionais.

A agitação em torno do movimento que já tomava corpo foi a primeira tarefa executada por Kemal, uma tarefa fácil após a intervenção grega, pois muitos protestos ocorreram com o desembarque. De acordo com Andrew Mango,

"em todo o país, o conflito étnico cresceu pelo deslocamento de grande número de cristãos da Anatólia e muçulmanos que fugiram da Rússia durante a guerra e aumentou ainda mais com as tentativas de repatriação. Armênios estavam retornando não só para áreas na Cilicia e Mesopotâmia sob ocupação francesa e inglesa, mas para a Anatólia central, reclamando casas tomadas por muçulmanos e ampliando o medo entre estes últimos de que seriam chamados a explicar sua participação nas deportações. O problema era particularmente agudo na costa do Egeu, onde 113 mil muçulmanos, a maioria refugiados que fugiram da Grécia após as guerras balcânicas, haviam sido assentados em casas gregas e agora estavam enfrentando a expulsão". ${ }^{229}$

Porém, a cidade de Samsun, com uma grande comunidade grega e oficiais britânicos de plantão, não era o lugar ideal para uma agitação nacionalista. Kemal deixou Samsun e se estabeleceu em Havza, onde insistiu para a formação de um ramo da 'Sociedade para a Defesa dos Direitos Nacionais'. Quando os oficiais britânicos em Samsun receberam a notícia de que muitos políticos haviam deixado Istambul para organizar uma oposição aos gregos, enviaram ao Sultão e ao Grão Vizir uma 'sugestão' para liberar Kemal de suas funções junto ao exército. O Sultão o chamou de volta à capital em 8 de junho (1919), mas Mustafa não obedeceu. Os oficiais do exército imperial que receberam ordens para prendê-lo, tampouco o fizeram. A partir desse momento, Kemal assumiu grande parte do comando do movimento e uma rede de resistência foi sendo formada no interior da Anatólia, ainda que contra a vontade do governo em Istambul. Muito pode ser dito acerca dessa personagem e muito do que se diz pode ser criado pela mitificação do homem, mas uma coisa é realmente inegável: Mustafa Kemal sabia conduzir seus subordinados, militar ou politicamente!

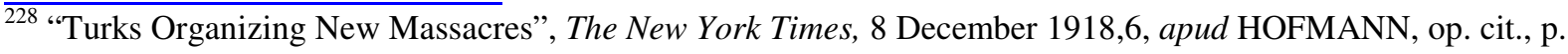
66.

${ }^{229}$ AKŞIN, I, 309-10, apud MANGO, op. cit., p. 222.
} 
Em julho de 1919, um grande congresso foi realizado em Erzerum, contando com três delegados da 'Defesa dos Direitos Nacionais' de cada região do império, sendo Kemal eleito presidente da mesa do comitê preparatório. Em 7 de Agosto, em sua sessão final, o congresso aprovou o Comitê Representativo conforme decidido por Kemal. A declaração desse congresso, o famoso "Pacto Nacional", proclamava a integridade das províncias orientais como parte do Estado Otomano e ia além defendendo o mesmo princípio para todas as terras sob domínio otomano quando o armistício foi assinado. Essa foi a primeira versão da declaração de independência turca e que leva a marca de Kemal. ${ }^{230}$

O congresso de Erzerum (Sivas) foi o primeiro ato do novo governo (não-oficial) otomano. Sem a aprovação do sultão, o "Governo Provisório", como ficou conhecido, seguiu praticando todos os atos políticos de um governo, inclusive com a justificativa de que, uma vez que a capital estava ocupada por forças aliadas, o Sultão era um refém das potências, portanto não era capaz de decidir pelo bem do país. O movimento nacionalista ganhou força e o governo provisório estabeleceu sua sede em Ankara, no centro da Anatólia, cidade de difícil acesso aos estrangeiros e também às tropas imperiais, mas bem servida pelas redes ferroviária e telegráfica, que os kemalistas utilizavam com muita eficiência. A Grande Assembleia Nacional foi estabelecida e funcionava normalmente com eleições regulares.

Em janeiro de 1920, Kemal informou ao Coronel Fahrettin sobre seus planos de combater os gregos na Anatólia Ocidental, embora seus exércitos nesse momento não passassem de promessas de alguns bandos de guerrilheiros, no máximo 50 mil homens. ${ }^{231} \mathrm{Em}$ 17 de Fevereiro, o Parlamento em Istambul aprovou o novo Pacto, por unanimidade, adicionando itens aos já declarados pelo congresso de Sivas. O pacto exigia que os habitantes dos países árabes, dos distritos perdidos para a Rússia na Anatólia Oriental em 1878 e da Trácia Ocidental pudessem escolher seu próprio futuro. Enquanto o documento dos nacionalistas se referia às terras do armistício de 1918, os parlamentares incluíram a expressão "e além". O documento anterior recebia de boa vontade a ajuda dos países estrangeiros, mas em Istambul foi decidido que o país não toleraria qualquer interferência em sua independência. Andrew Mango cita essas diferenças para demonstrar que, enquanto Kemal se concentrava em atitudes práticas e na diplomacia, os parlamentares repetiam os mesmos erros anteriores e somente conseguiam angariar a oposição dos aliados. ${ }^{232}$

\footnotetext{
${ }^{230}$ MANGO, op. cit., p. 241.

${ }^{231}$ Idem, p. 265.

${ }^{232}$ MANGO, op. cit., p. 269.
} 
A atitude conciliatória de Kemal se provaria a mais efetiva, ao longo da história. Entre todas as qualidades desse herói nacional, a mais destacada deve ser a capacidade de aproveitar as oportunidades que se colocam em seu caminho. É preciso ressaltar que durante todo esse tempo, desde 30 de outubro de 1918, quando foi assinado o armistício, os aliados ainda não haviam finalizado as tratativas da paz entre os beligerantes da Grande Guerra ${ }^{233}$. O Tratado de Sévres só foi assinado em agosto de 1920, quase dois anos mais tarde. Não faltam explicações para essa demora.

\subsection{1 - Os Aliados divergem}

Ainda antes e mesmo durante a guerra, os aliados concluíram entre si uma série de acordos com relação à divisão do Império Otomano quando fosse vencido. O primeiro deles ficou conhecido como acordo de Constantinopla, de março de 1915, no qual França e Inglaterra concordavam com algumas demandas russas. Após a derrota do Império Otomano, a Rússia ocuparia algumas partes da Anatólia oriental, Istambul e os Estreitos. ${ }^{234}$ Isso obviamente desagradou franceses e ingleses, que começaram a entender-se sobre a forma de contrabalancear essa superioridade russa. Nesse meio tempo, a Entente prometeu a porção sudoeste da Ásia Menor à Itália, como compensação, no tratado de Londres de abril de 1915.

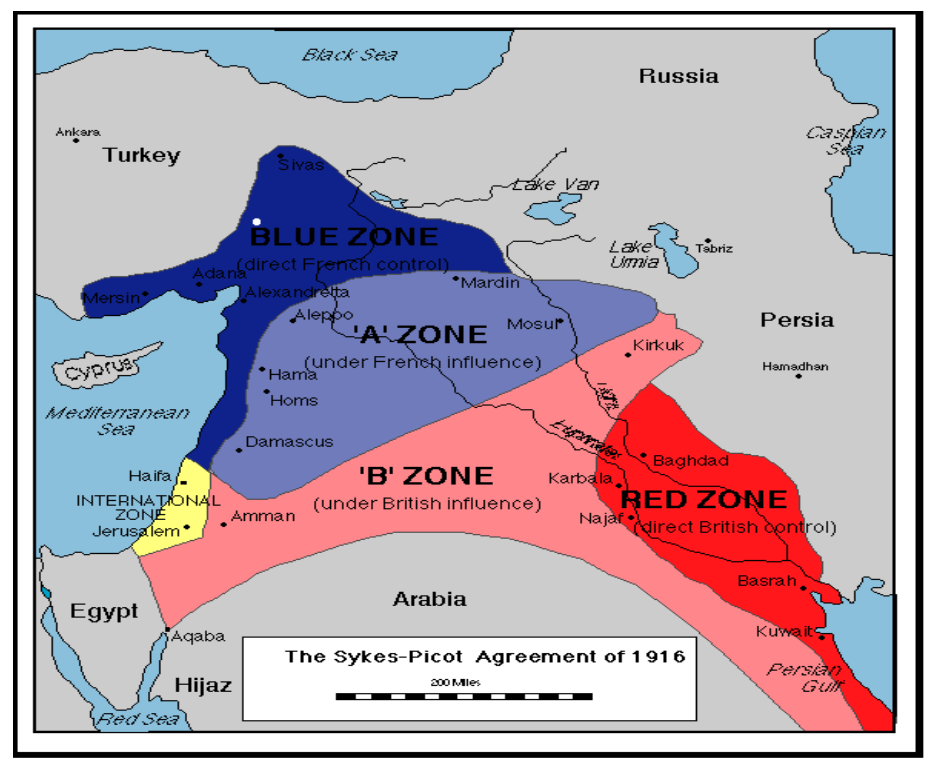

21 - Divisão do território otomano de acordo com o acordo Sykes-Picot. Reproduzido de http://www.clas.ufl.edu/users/oren/inr4204 middleeast.html

\footnotetext{
${ }^{233}$ Grande Guerra, ou Primeira Guerra Mundial - preferimos a primeira referência, uma vez que assim era conhecida naquele momento, obviamente, porque a Segunda Guerra ainda não havia ocorrido, sendo desnecessária a diferenciação.

${ }^{234} \mathrm{O}$ texto do acordo está disponível na internet em: http://muqtafi2.birzeit.edu/en/InterDocs/images/280.pdf
} 
Os entendimentos franco-britânicos levaram a um acordo entre seus representantes em 16 Maio de 1916 (Acordo de Sykes-Picot). ${ }^{235}$ Nesse acordo, a França ganhava a costa da Síria (e Líbano) e uma zona de influência exclusiva no interior da Síria, incluindo Mosul (rica em petróleo). Para a Inglaterra ficavam as províncias de Bagdad e Basra, com uma zona de influência adjacente para o oeste e alguns pontos no mediterrâneo em Acre e Jaffa. A palestina seria internacionalizada, menos os dois portos já citados. Entretanto, o acordo não previa o modo como seria a administração dessas zonas de influência e da palestina internacional. As terras do interior seriam entregues a um (ou alguns) reino árabe, o que coincidia em parte com as zonas de influência inglesa e francesa.

O acordo de Sykes-Picot foi sancionado pelos governos britânico e francês em maio e, mais tarde, o governo russo também aderiu. Este acordo permaneceu secreto até que os bolcheviques o publicaram, após a revolução. ${ }^{236}$

As negociações de paz, como seria de esperar, foram longas. A vitória aliada trouxe uma oportunidade única: o Sultão disposto a aceitar qualquer acordo que o mantivesse vivo e no trono e um império imenso, mergulhado em sangue e miséria, maleável para ser partilhado. Entretanto, as promessas proferidas durante o calor das batalhas eram as mais lembradas no momento da partilha. E para além das promessas aos pequenos servos, haviam imensos interesses nesse jogo de poderosos. Ao invés de uma reunião entre vencedores e vencidos, para discutir responsabilidades e punições, o que se viu em Sévres foi um encontro entre os vencedores, para acertar percentagens do botim.

Desde sempre, o interesse dos Aliados (e seus pequenos parceiros) era o expansionismo, ainda que por meio de influência política. Esse sempre foi também o interesse do Eixo. A Europa devia estar pequena demais para tantas aspirações. Até mesmo os Estados Unidos, que durante tanto tempo haviam mantido uma neutralidade 'filantrópica', tinham seus interesses no Oriente, especificamente no subsolo. Em Sévres, aguardavam o presidente Wilson e a decisão do congresso americano quanto a ratificar ou não os termos colocados em Versailles em junho de 1919, no qual estipulavam principalmente as medidas punitivas a serem aplicadas à Alemanha ${ }^{237}$. Neste acordo, o presidente Wilson colocou seus 'quatorze pontos', dos quais o de número 12 pode referir-se à questão armênia e divide ânimos até hoje:

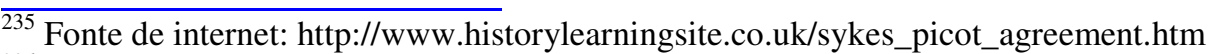

${ }^{236}$ ZURCHER, op. cit., p. 143-145.

${ }^{237}$ BLOXHAM, op. cit., p. 148.
} 
"12. The Turkish people should be governed by the Turkish government. Non-Turks in the old Turkish Empire should govern themselves" 238 .

Para os armênios, o presidente Wilson teria uma responsabilidade enorme. Em suas mãos foi depositada a tarefa de especificar as fronteiras Turquia/Armênia, referidas no Tratado de Sévres, um ano depois. Entretanto, a América não estava imbuída de filantropia o suficiente para deixar de notar que um mandato americano sobre a Armênia, especificamente, deixaria os franceses e os ingleses livres para dividir o restante da área. E a 'Armênia',239, naquele momento, não passava de uma zona desolada pela destruição.

A corrida pelo petróleo havia começado poucos anos antes e a primazia era americana, mas se os britânicos tomassem posse de uma área tão rica, sua frota poderia suplantar qualquer outra em pouco tempo. Uma outra solução foi ventilada: um mandato americano para a Turquia como um todo! Essa foi a ideia levada pelo jornalista americano Louis Browne ao congresso dos nacionalistas em Sivas, em setembro de 1919. Este senhor havia sido enviado por Halide Edib, uma revolucionária turca com importantes ligações com os kemalistas. A ideia de Edib era que 'um mandato americano em toda a Turquia era o menor dos males'.240

Uma outra razão para a lentidão das decisões sobre a paz era justamente a sobreposição das áreas prometidas aos aliados. Vários autores afirmam que o premier grego Venizelos tinha uma grande influência sobre seu colega britânico, Sir Lloyd George. É provável, dadas as circunstâncias, que houvesse certa preferência do inglês pela administração grega daquela parte do mundo. Sir Lloyd George enfrentou a oposição de muitos para manter a opção pela intervenção grega em Esmirna. Mas não significa que suas razões fossem de amizade e respeito pelo amigo grego.

$\mathrm{Na}$ verdade, a Grécia era uma ferramenta bem mais fácil de manejar que a Itália. Embora esta última tenha lutado desde o início ao lado dos ingleses e apesar de a promessa à Itália ter sido feita antes, os italianos não seriam de grande utilidade para a Inglaterra quando instalados na Ásia Menor. Ao contrário, as relações cordiais com os turcos apontavam para vantagens italianas no antigo império, o que não correspondia com as aspirações britânicas.

Já os gregos... bem, os gregos naquele momento, naquele local, eram uma verdadeira bomba relógio! Contavam-se por dias o momento em que todo o Império Otomano explodiria em pedaços. Cobiçados pedaços com donos pré-determinados.

\footnotetext{
$\overline{238} \mathrm{http} / / /$ www.historylearningsite.co.uk/woodrow_wilson1.htm - mantivemos a versão original em inglês, para que se verifique o duplo sentido que permite o questionamento até os dias de hoje.

${ }^{239}$ Entre aspas porque ainda não existia uma Armênia estabelecida.

${ }^{240}$ DOBKIN, op. cit., p. 86.
} 
É difícil saber se Venizelos, um político renomado e de merecido reconhecimento internacional, tinha ciência de sua posição de marionete. Sendo um político tão experiente, é igualmente difícil imaginar que não soubesse. Manipulado ou não, o fato é que a Grécia também tinha interesse em um dos pedaços e não abriu mão dessa possibilidade. Enfim, a bomba-relógio foi instalada. E, a partir daí, cada qual buscou abrigo onde foi possível. Um a um, os aliados foram se acomodando na melhor posição para aguardar o desfecho. Italianos e franceses assinaram acordos secretos com Kemal, os soviéticos forneceram armas e munição. Inglaterra e Estados Unidos, para manter a fama de 'filantrópicos', optaram pela neutralidade.

O resultado foram três anos de uma guerra cada dia mais sangrenta, em que lutavam homens movidos por ódios e códigos de honras, e cuja "solução" final foi a eliminação quase completa do elemento cristão das terras turcas.

\subsection{2 - Guerra greco-turca}

Existe muita controvérsia a respeito das razões que levaram à entrada da Grécia na guerra. Segundo Abbott, a pressão aliada sobre o premier grego, para que autorizasse o desembarque de tropas em Thessalônica (em 1915) tomou proporções tais que o estadista teria chegado ao ponto de falsear a autorização do rei, conseguindo que as tropas chegassem e desembarcassem, renunciando logo em seguida, quando descoberta sua estratégia ${ }^{241}$.

Ao mesmo tempo, a pressão alemã sobre o rei Constantino, pelas relações de família com o Kaiser Wilhelm, exigia a neutralidade. Não significa que o exército grego fosse tão poderoso que todos temessem sua intervenção. Mas era de conhecimento público o ódio existente entre turcos e gregos dentro do império otomano e esse tipo de sentimento sempre foi uma excelente ferramenta de manobra em tempos de guerra, em especial quando manejada por mãos hábeis. A Alemanha ofereceu e concedeu um empréstimo de grande soma à Grécia, contando com a sua lealdade. O valor foi aceito, e era muito necessário ao país, mas a oferta dos aliados era muito mais valiosa - "nós aceitamos de coração que vocês recebam as grandes concessões na Ásia Menor", disse o Ministro Russo em Atenas, em reunião com o seu colega Britânico, "mas com relação a Constantinopla, preferimos que vocês não entrem lá. ${ }^{242}$

Baseado nessas promessas, reiteradas em várias outras ocasiões, o Primeiro Ministro Grego conseguiu de fato convencer o povo de que esta seria uma forma 'segura' de alcançar

\footnotetext{
$\overline{{ }^{241} \text { ABBOTT, op. cit., location } 466}$ kindle fire reader

${ }^{242}$ 'Conversation with M. Demidoff', Politis, Athens. 25 Feb./10 March, 1915, apud ABBOTT, op. cit., location 509 kindle fire reader
} 
os objetivos traçados desde a formação do Estado Grego, um século antes. E com isso, colocou à disposição dos Aliados suas tropas e sua vontade, juntamente com toda a carga emocional que pudesse ser útil aos desígnios dos poderosos.

A intervenção grega durante a guerra pode ser descrita como 'mínima'. As tropas gregas enfrentaram os búlgaros com uma significante vitória - que levou à rendição da Bulgária em 29 de setembro de 1918 - e mais nada, pelo menos não de grande importância. Mas após a guerra, a presença grega foi, de certo modo, determinante para que todo o cenário se transfigurasse. O Império Otomano rendido, vencido e exausto, de modo geral conformado com sua derrota, recobrou forças pelas mãos dos nacionalistas, justamente porque o povo turco não aceitaria jamais a dominação grega.

Por conta desse sentimento misto de orgulho e ódio, os nacionalistas, liderados por Kemal, conseguiram levantar um exército e provisões, armamento e munições, além de disposição para a luta, literalmente a partir do que sobrou do país. Milhões haviam morrido de fome durante a guerra e quase todos os homens muçulmanos enviados para o front haviam perecido ou desertado, humilhados. As famílias nas propriedades rurais mal tinham como sobreviver. Mas o exército revolucionário kemalista se ergueu e enfrentou uma nova guerra de quase três anos. Foi a vitória nessa última empreitada que permitiu a criação da orgulhosa República Turca em 1923, cujo prestígio internacional só cresceu desde então. A Turquia é hoje um país poderoso, respeitado e bem relacionado, sendo suas condições aceitas pela comunidade internacional. "A que preço?" perguntamos.

\section{Esmirna}

Desde a antiguidade, reconstruída por ordem de Alexandre, o grande, Esmirna era o porto mais importante da Ásia Menor e uma das cidades mais importantes e mais agradáveis da região. Diplomatas europeus costumavam colocar Esmirna entre as melhores cidades para se trabalhar, algumas vezes mesmo à frente de Paris. A cultura cosmopolita da cidade atraía estrangeiros de todas as partes do mundo, suas escolas e academias eram famosas e os negócios floresciam. No século XIX, Esmirna tinha uma população de mais de um milhão de habitantes, dos quais mais de 200 mil gregos e 15 mil armênios, ${ }^{243}$ além de vários milhares de americanos, franceses, italianos, ingleses, austríacos, holandeses. Era a segunda maior cidade do Império Otomano e o destino da maior parte dos visitantes.

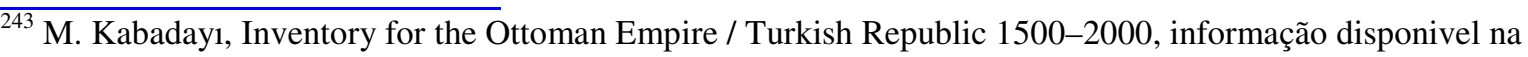
wikipedia
} 
Durante a guerra, devido à forte presença estrangeira, à exceção de boicotes e atos de terror contra os comerciantes gregos e armênios, a população de Esmirna não sofreu deportações ou massacres. Algumas tentativas foram veiculadas pelas autoridades locais, mas a repercussão internacional impediu a maior parte das agressões. Os comerciantes locais seguiram com seus negócios, os carregamentos continuaram chegando e saindo do porto e a vida continuou, na medida do possível, normalmente. Até 15 de maio de 1919, o dia em que chegaram as tropas gregas, quando a população grega, os armênios e levantinos exultavam no cais, acenando bandeiras azuis e brancas. Ao mesmo tempo, os muçulmanos realizavam protestos na cidade.
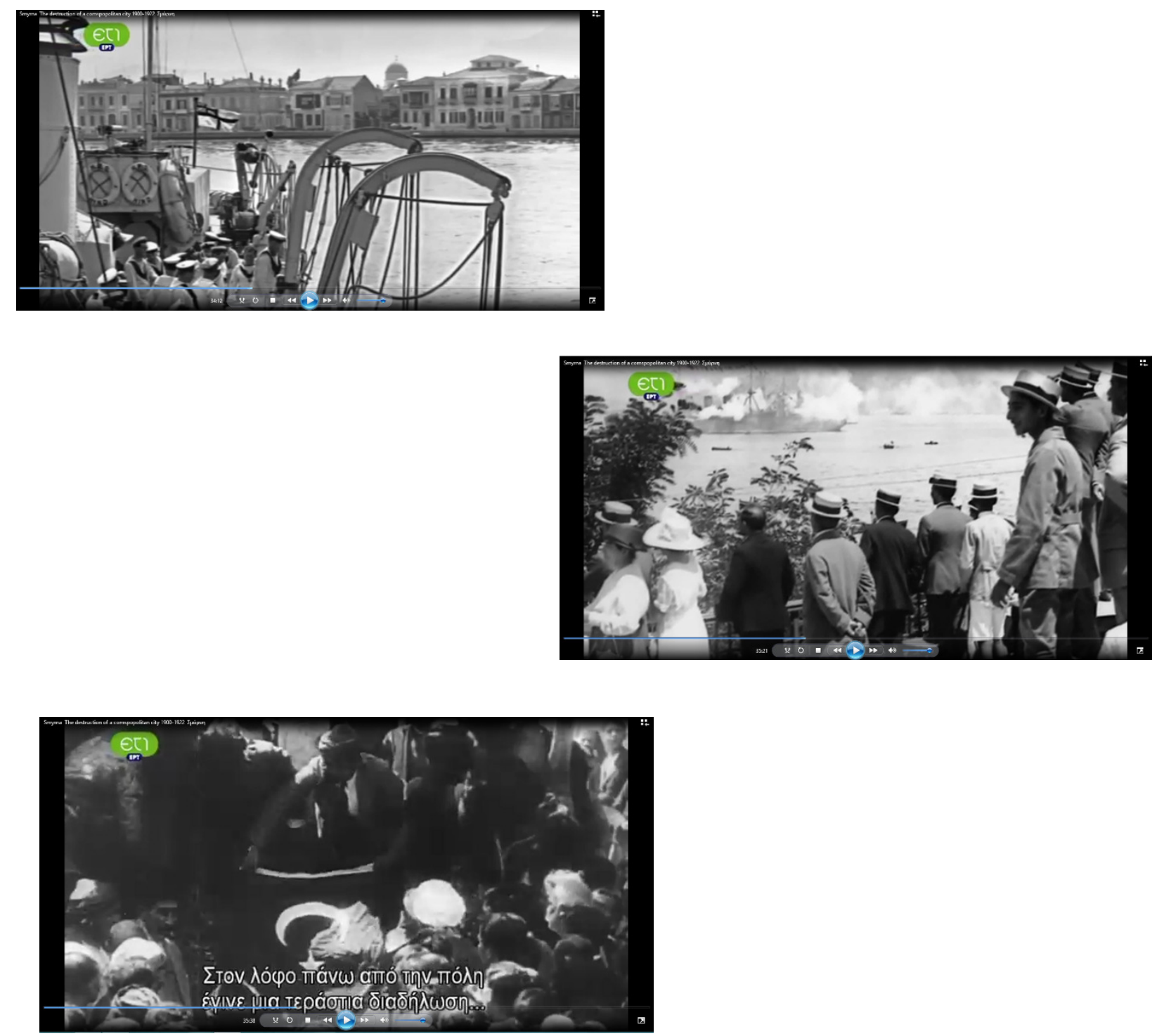

22 - A chegada das tropas gregas em Esmirna, a população saudando os marinheiros e os protestos turcos. Fotografias reproduzidas do documentário Smyrna - The Destruction of a Cosmopolitan City 1900-1922, de Maria Iliou, realizado pelo Proteus Archive Preservation Project, 2011 
Os aliados estavam cientes de que o controle grego em Esmirna podia suscitar outra guerra. ${ }^{244}$ Porém, a ascensão de um poder local leal aos seus desígnios interessava aos britânicos, por proporcionar uma base no mediterrâneo. A França e os Estados Unidos temiam a ambição italiana. Sendo assim, a petição de Venizelos vinha de encontro à política de desintegração otomana que estava em prática há tanto tempo. A perspectiva de um controle grego na região foi suficiente para acirrar os ânimos turcos.

"Nós queríamos que (os ingleses) viessem, nós queríamos que controlassem o país! Mas eles mandaram os Gregos! Isso é impossível!"’245

Na verdade, embora a população local talvez não tivesse ciência disso, a Grécia não recebeu o governo da cidade de forma perene. O que os gregos conseguiram foi uma concessão para administrar a cidade durante cinco anos, após os quais, seria feito um plebiscito para que o povo decidisse qual governo preferiria. No mesmo dia do desembarque, ocorreram problemas. Novamente, para a descrição desse episódio, pode-se encontrar divergência entre os autores pró-turcos e pró-gregos. Andrew Mango, biógrafo de Atatürk, descreve:

"o desembarque dos gregos em 15 de maio foi desastroso, mas previsivelmente, errado. Assim que as tropas gregas se dirigiram para as tendas, onde o comandante otomano Ali Nadir Pasha foi instruído a não oferecer resistência, um turco na multidão disparou um tiro, matando o porta-estandarte grego. As tropas gregas entraram em pânico e começaram a atirar nas tendas e na sede do governo. Oficiais turcos foram espancados e humilhados, propriedade turca foi roubada. Durante o primeiro dia, 300 a 400 turcos foram mortos ou feridos, contra 100 gregos, dois deles soldados. A desordem se espalhou para o interior. As aliados enviaram uma comissão de inquérito. Os gregos impuseram Lei Marcial e mandaram um Comissário duro, Aristeidis Stergiadis, que conseguiu controlar a grande comunidade grega local e manter o governador otomano em serviço. Mas o dano à coabitação de gregos cristãos e turcos muçulmanos foi irreparável, e o sentimento nacionalista turco foi inflamado ao longo do país.",246

O cônsul americano George Horton, que embora não estivesse presente no momento, recebeu informações de testemunhas americanas ao chegar à cidade, poucos dias depois, relata:

"Enquanto os gregos prosseguiam em direção ao Konak, ou Casa do Governo, receberam tiros. Fui informado por inúmeras testemunhas oculares, não nativos de Esmirna, que os tiros aumentaram para fuzilaria. Os gregos fizeram um número de prisioneiros que levaram com as mãos para cima até o cais à vista dos navios americanos e aliados. Dizem que eles atacaram vários prisioneiros com baionetas à vista das pessoas nas casas e nos navios. Não houve massacre, no sentido de matança geral de prisioneiros,

\footnotetext{
${ }^{244}$ BLOXHAM, op. cit., p. 149.

245 Protesto de um mercador turco de Esmirna a seu empregado armênio, na manhã da ocupação, apud DOBKIN, op. cit. p. 68.

${ }^{246}$ MANGO, op. cit., p. 217.
} 
mas alguns eles, de fato, mataram; esse ato parece criminoso, desprezível e idiota, e os gregos devem explicar isso como puderem. Houve um levante na cidade, como um motim, e mais turcos foram mortos. Estimativas dadas por americanos presentes contam os mortos entre 50 e 300. Também houve roubos em Esmirna e nos arredores.

Eu estava presente em Esmirna quando os líderes dos distúrbios foram condenados e executados. Eu estava aqui quando o governador geral grego mostrou grande habilidade, suprimiu as desordens completamente em curto espaço de tempo e puniu severamente os culpados. Três dos líderes, gregos, foram conduzidos a uma praça central e publicamente executados. Muitos outros tiveram sentenças menores (dos 74 sentenciados, 48 eram gregos, 13 turcos, 12 armênios e 1 judeu). A população foi informada que gregos que perturbassem a paz seriam punidos mais severamente que turcos, uma política que foi conduzida durante todo a administração grega e contribuiu não pouco para a impopularidade do governador geral entre os cristãos nativos." 247

\section{Segundo Marjorie Dobkin,}

"os gregos insistem em que os italianos teriam precipitado a violência, notando que a fumaça não havia ainda se dissipado e o oficial naval italiano já estava batendo na porta do Admiral britânico, exultando que os gregos eram obviamente incapazes de manter uma ocupação pacífica. Ninguém pode negar que elementos criminosos poderiam facilmente ter sido envolvidos, depois que a investigação descobriu que todos os prisioneiros das cadeias de Esmirna haviam misteriosamente escapado na noite anterior ao desembarque." 248

A divergência nas descrições se explica, pois a partir desse episódio foram se desenrolando os fatos que culminaram com a guerra greco-turca. Por isso, autores de um e outro lado, buscam garantir a responsabilidade do lado oposto pelo início dessa nova tragédia.

Apesar dos problemas iniciais, a administração grega da cidade não causava tantas fricções. Houve um período em que o governador Stergiadis conseguiu manter a paz e a prosperidade seguiu. A população continuou sua vida, comércio e encontros sociais. A vida social era muito importante em Esmirna, as festas eram frequentes e não deixaram de acontecer até poucos dias antes do incêndio que destruiu a cidade. ${ }^{249}$

A população muçulmana da cidade não perdeu seus direitos, principalmente devido ao rigor das leis instituídas por Stergiadis. Os gregos apoiavam as instituições educacionais com fundos do próprio tesouro nacional, inclusive as escolas muçulmanas. A saúde também foi muito melhorada durante a administração grega, bem como os trabalhos sociais que incluíam os cuidados com órfãos realizados pelas instituições estrangeiras, principalmente americanas, como a Y.M.C.A. e a Near East Relief, que recebeu dinheiro grego para dar assistência à viúvas muçulmanas. ${ }^{250}$

\footnotetext{
${ }^{247}$ HORTON, op. cit., p.48-50.

${ }^{248}$ DOBKIN, op. cit., p. 67.

${ }^{249}$ Informação retirada do Documentário de Maria ILIOU, op. cit.

${ }^{250}$ HORTON, op. cit., p. 55-59.
} 
O cônsul George Horton afirma ainda que, durante os anos de administração grega, viajava frequentemente ao interior e verificou que havia segurança e que os habitantes gregos e turcos das pequenas vilas conviviam pacificamente. Entretanto,

"com relativa frequência, dois ou três oficiais gregos eram encontrados de manhã com as gargantas cortadas, o que levava ao envio de ordens para as vilas que os nomes dos assassinos fosse revelado ou a vila seria queimada. (...) os turcos nunca revelavam os nomes dos assassinos e em duas ocasiões recebi em meu escritório cidadãos de alguma vila reclamando que sua cidade havia sido queimada. Nas duas ocasiões, perguntei 'oficiais gregos foram mortos na noite anterior?' e eles responderam 'sim, mas não revelamos os nomes, porque não sabemos quem são". ${ }^{251}$

Algumas vezes também ocorriam ataques dos chetes $^{252}$ à população grega, principalmente no campo. Essas pequenas agressões à população cristã levaram à reação do exército grego. "Para proteger os aldeões", segundo os gregos, ou "para ganhar terreno na região", segundo os turcos, o fato é que o exército grego deixou os muros da cidade e começou a avançar lentamente para o interior da região de Aydin. Em toda a região, havia uma grande população grega, os números variam de 500 mil a 1 milhão. A incorporação da região inteira, portanto, estava nos planos de Venizelos desde sempre, esse era o próprio conceito da Megali Idea. ${ }^{253}$

Não fica difícil deduzir que a expansão da área controlada pelo exército servia aos propósitos gregos e não precisava de muitas justificativas. Também não é difícil imaginar que cada metro de terreno conquistado fazia girar mais rápido o cronômetro da bomba-relógio. Os aliados não precisariam esperar por muito tempo. Com apoio principalmente inglês, mas a princípio contando pelo menos com a não-oposição americana e francesa, o exército grego iniciou essa campanha em direção ao interior, enfrentando pouca resistência e conquistando muito território, rapidamente, até o início de 1921. Embora sofrendo derrotas duras nesse início, a resistência turca crescia em força. Kemal enviou uma proclamação à nação, com ordens para requisitar suprimentos da população civil:

"roupas de baixo e botas para o exército; quarenta por cento de todo o estoque de tecido, couro, farinha de trigo, sabão e velas; os que tivessem transportes, deviam transportar os suprimentos $100 \mathrm{~km}$ por mês, sem cobrar; todas as armas deviam ser entregues ao exército; um quinto de todos os cavalos, carros e carruagens deviam ser entregues aos militares" $" 254$.

\footnotetext{
${ }^{251}$ HORTON, op. cit., p. 60.

${ }^{252}$ Chetes são os grupos de paramilitares que atuavam muitas vezes por conta própria assaltando a população, e que se juntaram ao exército de Kemal com o desenvolvimento do movimento nacionalista.

253 'Grande Ideia', um mote criado pelos políticos gregos em 1844, cujo ideal era a 'libertação' de todos os gregos que estivessem sob jugo otomano (irredentos), utilizando para isso uma campanha expansionista que deveria incorporar as regiões onde vivessem gregos.

${ }^{254}$ MANGO, op. cit., p. 318.
} 
A política em Istambul começou a se tornar mais pró-kemalista. A ocupação aliada na cidade facilitava a diplomacia, já que a França e também a Itália podiam usar a brutalidade inglesa contra a população turca, instrumento para deixar claro a Kemal que não estavam de acordo com aquela atitude, o que dava a ele uma abertura para dividir os aliados. ${ }^{255} \mathrm{~A}$ assinatura, por fim, do tratado de Sévres em agosto de 1920, trouxe mais lenha para a ardente fogueira. Segundo Dobkin, Churchill teria dito depois de ratificar o tratado: "por fim, paz com a Turquia, e para ratificar isso, guerra com a Turquia!", mas nenhuma das potências tinha intenção de ir à guerra com a Turquia e Kemal sabia disso. ${ }^{256}$

Os gregos, afinal, estavam lá para isso. E a guerra seguiu, com avanço grego considerável. No final de 1920, eleições na Grécia derrubaram Venizelos e um plebiscito trouxe de volta ao trono o Rei Constantino, o mesmo que havia sido forçado pelos aliados a deixar o país em 1917. O Rei chegou a Esmirna triunfante em junho de 1921, aclamado pela população. Essa foi a melhor oportunidade que os ingleses poderiam ter conseguido para se livrar de uma vez do problema em que se haviam metido. Nesse momento, os ingleses eram os únicos a apoiar ainda o exército grego, inclusive com armas e suprimentos. Todos os seus 'amigos' já faziam esse serviço do outro lado do front. O crescimento do movimento nacionalista e da força política de Kemal indicavam que a balança, contra todas as expectativas iniciais, podia afinal pender para aquele lado e a Inglaterra não deveria estar do lado errado.

Sob pretexto de não aceitar o retorno de Constantino ao trono grego, abruptamente, cessou o apoio inglês às fileiras gregas. Em outubro de 1921, foi firmado o acordo entre britânicos e o governo de Ankara. Entre as condições estava a liberação dos antigos companheiros de Kemal, presos em Malta desde a ocupação aliada, em troca da liberação de prisioneiros ingleses. $^{257}$

Nesse momento da guerra, o front grego se estendia por mais de $100 \mathrm{~km}$ com duzentos mil homens ${ }^{258}$ e era extremamente difícil abastecer adequadamente as tropas. Ainda assim, no início do inverno de 1921, os soldados gregos encontravam-se a menos de $100 \mathrm{~km}$ de Ankara. Seus canhões podiam ser ouvidos na cidade e apavoravam os políticos na Grande Assembleia, a ponto de terem à mão um plano de fuga para Sivas, em caso de emergência. Nesse ponto, à beira do Rio Sagarios (Sakaria em turco), ficaram estacionados os exércitos, frente a frente, por quase um ano. Kemal reunia suas forças, os gregos se mantinham como podiam.

\footnotetext{
${ }^{255}$ BLOXHAM, op. cit., p. 154.

${ }^{256}$ DOBKIN, op. cit., p. 90.

${ }^{257}$ MANGO, op. cit., p.328

${ }^{258}$ Idem, p. 315.
} 
"A Grécia estava praticamente falida, com os empréstimos ingleses e americanos cancelados. $O$ inverno foi rigoroso, roupas e comida extremamente racionados, equipamentos deteriorados, liderança desmoralizada. Os homens estavam isolados e abandonados em uma terra hostil. 'Por mais de nove meses, os turcos esperaram e os gregos aguentaram' escreveu Churchill”. 259

Segundo Mango, em junho de 1921, um navio grego bombardeou a cidade de Inebolu, perto de Samsun. O comandante Nurettin avisou o staff em Ankara que, em vista do perigo de um desembarque grego em Samsun, todos os homens gregos entre 15 e 50 anos deviam ser deportados para o interior. Kemal e seu governo concordaram com isso em 16 de Junho. De acordo com o relatório oficial (turco), cerca de 25 mil pessoas foram deportadas. Diante da indignação ocidental pelo tratamento dado aos gregos do Pontus, Kemal apontou aos representantes ingleses e franceses com quem se encontrou em 18 de junho, que

"a responsabilidade pelo sofrimento dos civis gregos e turcos era daqueles que haviam usado o exército grego para extinguir a liberdade e independência turcas". A mensagem era clara, Kemal desejava a amizade do mundo civilizado. ${ }^{260}$

Durante o verão de 1922, o exército de Kemal foi reorganizado sob novos líderes, com alguma dificuldade. O comando do Primeiro Regimento ficou a cargo de Nurettin, o 'martelo' dos gregos e curdos da Anatólia. O Exército também recebeu armamentos tanto dos franceses como dos bolcheviques. Os 'restos' deixados pelos franceses e italianos ao sul da Anatólia foram doados para os nacionalistas. ${ }^{261}$

Em 30 de agosto de 1922, os gregos sofreram o seu último revés, uma derrota fragorosa diante do primeiro regimento de Nurettin, em Dumlupinar. Mustafa Kemal liderou pessoalmente o ataque decisivo. Aqueles gregos que escaparam da morte, bateram em retirada em completa desordem. Por onde passavam os soldados em fuga, os cristãos entendiam que algo semelhante os esperava e seguiam junto. Soldados em desespero queimavam as vilas por onde passavam. ${ }^{262}$ Seu destino era, naturalmente, Esmirna, onde ficava o quartel general grego. Quando chegaram as tropas, chegaram também várias dezenas de milhares de aldeões do interior da Anatólia, trazendo poucos pertences e muita esperança de salvação pelo mar. $\mathrm{O}$ exército turco recebeu então a seguinte ordem de Kemal: "Tropas! O Mediterrâneo é seu objetivo! Em frente!". 263

\footnotetext{
${ }^{259}$ DOBKIN, op. cit., p. 95.

${ }^{260}$ MANGO, op. cit., p. 331.

${ }^{261}$ Idem, p. 335.

${ }^{262}$ DOBKIN, op. cit., p. 100.

${ }^{263}$ MANGO, op. cit., p. 342.
} 
Uma vez que era iminente a chegada das tropas turcas e que um novo encontro era impensável para o desesperado exército grego, ao chegar a Esmirna, os navios gregos disponíveis embarcaram todos os seus soldados e deixaram o porto o mais rápido possível. Os aldeões que haviam acompanhado o exército desejavam embarcar também, mas foram informados que não havia espaço para civis e deixados no porto. Espalharam-se pela cidade em desespero, buscando abrigo nos consulados e nas instituições estrangeiras. Muitos foram recebidos, mas muitos permaneceram do lado de fora. Enquanto isso, a população da cidade ainda não acreditava que pudesse haver qualquer problema imaginando que os turcos não ousariam qualquer enfrentamento diante dos 21 navios de guerra franceses, ingleses, italianos e americanos estacionados no porto.

Em 9 de setembro, as tropas de Nurettin chegaram à cidade bem alinhadas, uniformizadas e "pacíficas". Os soldados turcos distribuíram panfletos afirmando sua intenção pacífica, o que foi ratificado por inúmeras notas dos observadores desde seus navios. Kemal chegou no dia seguinte e prometeu, ostensivamente, que qualquer soldado turco que fosse visto maltratando a população ou saqueando pagaria com a vida. Nesse mesmo dia, indicou Nurettin Pasha como governador de Esmirna.

Ato contínuo, Nurettin convocou o Bispo Chrisóstomo para uma reunião. Não se sabe o que foi dito durante a entrevista, mas em seguida Nurettin conduziu o bispo, a mais alta autoridade grega da cidade, até a multidão que aguardava nas ruas. Não se sabe ao certo por que razão ele teria feito isso, mas o fato é que o Bispo foi torturado e morto pela multidão. ${ }^{264}$

Os saques e o massacre de todo e qualquer cristão que estivesse ao alcance foram relatados por sobreviventes. Soldados turcos invadiam casas, espancavam as pessoas nas ruas onde corpos se amontoavam, atrapalhando o transito:

"Capitão Hepburn contou trinta e cinco corpos em seu caminho ao consulado. Ele esteve contando corpos toda a manhã em suas viagens pela cidade, mas ainda que estivesse ansioso para manter a conta correta, estava tendo dificuldades para distinguir os novos dos velhos",265.

Aqueles que não encontraram abrigo nas instituições estrangeiras, por falta de espaço ou porque os governos dos países representados não queriam que Kemal os visse ajudando a população, permaneciam às portas, implorando, desesperados. Todas as casas do bairro armênio e grande parte das do bairro grego foram saqueadas e seus proprietários mortos. Horton conta que viu pessoalmente muçulmanos da cidade, com armas nas mãos, olhando

\footnotetext{
${ }^{264}$ HORTON, op. cit., p. 86.
}

${ }^{265}$ DOBKIN, op. cit., p. 145. 
para dentro das casas de armênios e gregos, como um caçador que espreita a caça. ${ }^{266}$ As mulheres mais jovens sofriam abusos ou eram levadas pelos soldados. Soldados turcos e também oficiais, levavam tudo o que podiam encontrar. Após vários dias de terror, soldados turcos foram vistos derramando combustível em ruas e casas de onde, em poucos minutos, subia o fogo. Aqueles que tentaram fugir da cidade encontraram um cordão de tropas turcas, com fuzis preparados, impelindo-os de volta, em direção ao cais do porto. Como testemunhas, figuram o cônsul americano George Horton, professores das escolas americanas, funcionários da YMCA local, Nino Russo (marinheiro do navio italiano Vittore Imanuele), a Sra Millie Mills, diretora do 'American International College' em Esmirna, o reverendo Abraham Hartunian, pastor da igreja Armênia, e outros sobreviventes entrevistados por Dobkin. ${ }^{267}$

O incêndio durou vários dias e deixou em cinzas os bairros grego e armênio. $\mathrm{O}$ bairro turco não foi afetado. Dezenas de milhares de pessoas se espremiam no cais; muitos lançavam-se à água tentando chegar a nado até os navios ingleses, franceses, americanos, ali atracados apenas para garantir a integridade física e as propriedades dos cidadãos de seus países, nada mais. Os marinheiros dos navios não tinham autorização para receber nem mesmo aqueles que nadavam até lá, ainda que diante do risco de afogamento.

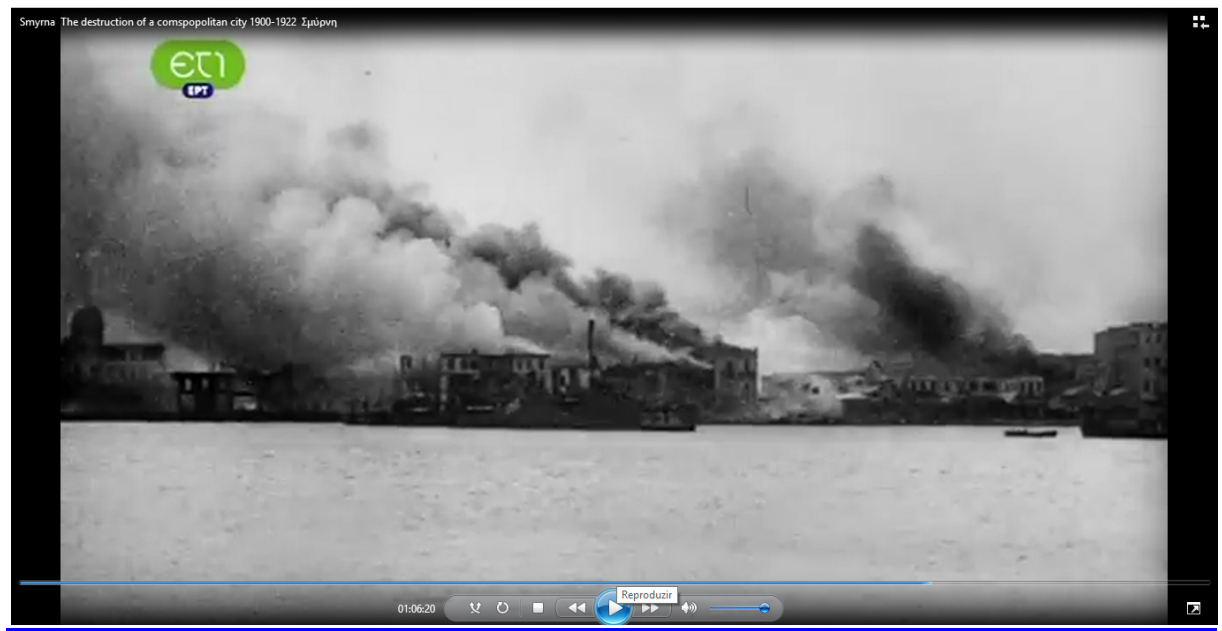

23 - Esmirna em chamas. Fotografia reproduzida do documentário Smyrna - The Destruction of a Cosmopolitan City 1900-1922, de Maria Iliou, realizado pelo Proteus Archive Preservation Project, 2011.

Durante o mês de setembro, Kemal ficou na cidade e os aliados também permaneceram aí atracados, com vista para o porto repleto de desesperados, cadastrando

\footnotetext{
${ }^{266}$ HORTON, op. cit., p 82.
}

267 DOBKIN, op. cit. p. 135. 
cidadãos de seus países e levando-os a bordo de seus respectivos navios. Ignoravam pedidos de quaisquer outros, salvo honrosas exceções.

As descrições dos sobreviventes sobre esses dias de terror e desespero são muitas e podem ser encontradas em diversos livros, principalmente gregos. O cônsul americano Horton é bastante detalhista em sua obra:

"um americano nativo me reportou que havia visto um homem apanhar até a morte dos turcos, munidos de bastões, 'até que não tivesse nenhum osso inteiro em seu corpo"”; "outro americano nativo entrou branco e tremendo em meu escritório e contou que "havia visto 'na esquina' alguns soldados turcos pararem um velho e começarem a falar com ele. $\mathrm{O}$ velho havia então levantado as mãos, com os dedos separados em atitude de súplica, quando um dos soldados cortou suas mãos com uma espada e o jogou no chão"; "Sir Harry Lamb, o cônsul geral britânico, veio pedir-me para enviar dois carros a Bournabat (subúrbio de Esmirna) para buscar o doutor Murphy, um cirurgião de exército aposentado, e sua família. Ele me relatou que turcos entraram em sua casa e disseram ao doutor não se assustar, pois não queriam machucar ninguém. Eles haviam vindo apenas para violar as mulheres. Quando o médico tentou evitar isso, foi espancado violentamente e acabou morrendo pelos ferimentos recebidos". 268

Aqueles que permaneciam no cais, nas mais precárias condições possíveis, ainda precisavam preocupar-se com os turcos que os atacavam durante a noite:

"O curioso era, ele disse, como eles gritavam toda noite à meia-noite. Eu não sei porque eles gritavam a essa hora. Nós estávamos no porto e eles no píer e à meia-noite começavam a gritar. Nós acendíamos luzes sobre eles para aquietá-los."269

\footnotetext{
${ }^{268}$ HORTON, op. cit., p. 84-85.

${ }^{269}$ HEMINGWAY Ernest - In Our Time, apud DOBKIN, op.cit., p. 183.
} 


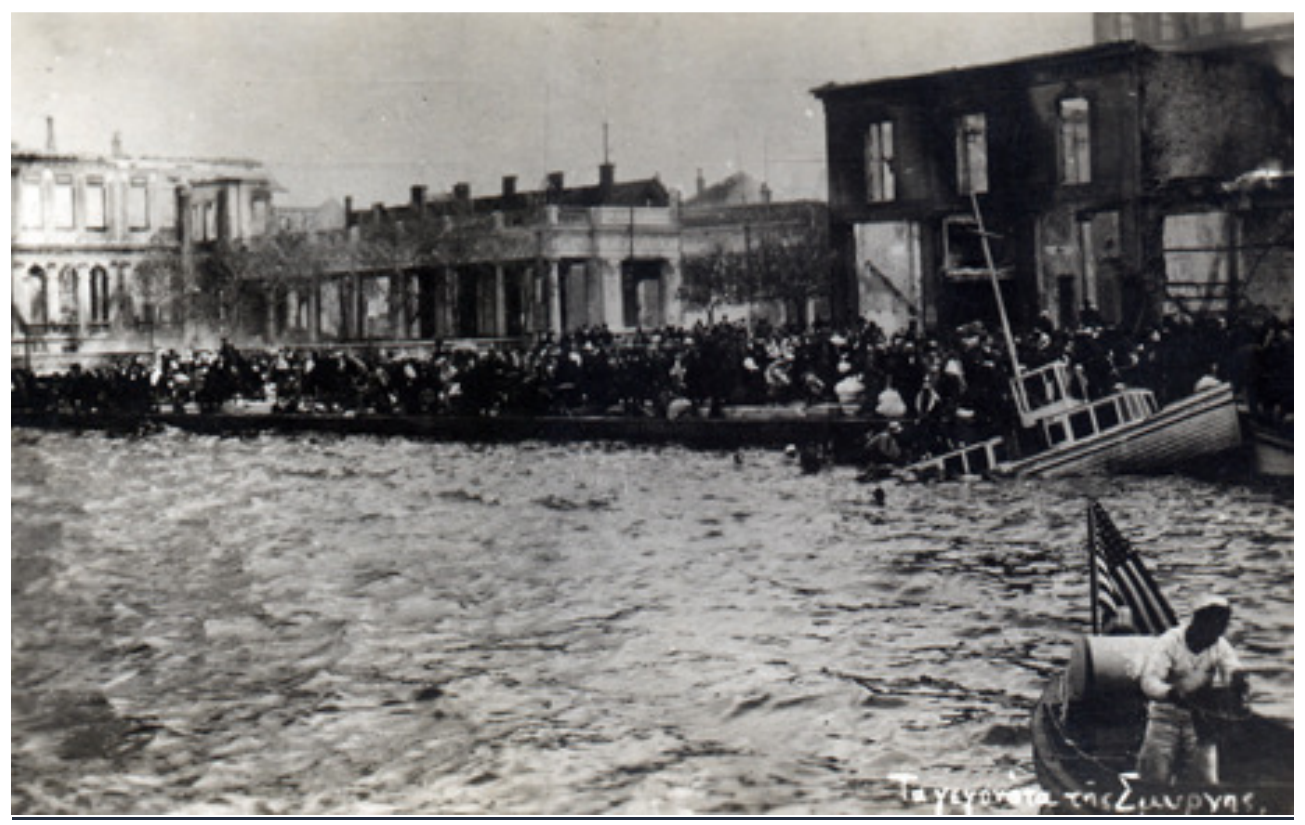

24 - Porto de Esmirna em chamas repleto de refugiados em pânico, s.d. AGMI collection (em exposição online no site do Museu do Genocídio em Yerevan.

Por fim, Kemal lançou um ultimato: aqueles gregos e armênios que ainda estivessem em Esmirna após o 30 de setembro seriam conduzidos para campos de trabalho no interior. Em vista disso, algumas boas almas começaram a buscar formas de efetuar essa retirada. Asa Jennings - um americano secretário da YMCA, que trabalhava em Esmirna há pouco mais de um ano - foi até Mitilini, a ilha grega em frente ao golfo de Esmirna, a poucos quilômetros de distância, e com alguma astúcia ${ }^{270}$ conseguiu em 23 de setembro, que navios gregos aportados ali se mobilizassem e entrassem no porto da cidade para retirar cerca de duas centenas de milhares de pessoas que ainda esperavam no cais, dia após dia, rezando por navios ${ }^{271}$. Os soldados turcos permitiram o embarque, mas basicamente só o das mulheres, crianças e velhos. Os homens em idade de trabalho que ainda podiam andar foram levados para o interior, em marchas semelhantes àquelas já utilizadas anteriormente para as 'deportações'. Alguns ainda lograram sobreviver para contar suas histórias.

"Historiadores e arqueologistas declararam que apenas a destruição de Cartago pelos romanos podia ser comparada ao fim de Smyrna, em termos de horror, selvageria e sofrimento humano. Mesmo assim, não havia nenhuma frota de navios cristãos em

\footnotetext{
$\overline{270}$ Jennings conseguiu enviar a Atenas um pedido para que autorizassem o envio de navios gregos a Esmirna, identificando-se como presidente do American Relief Committee em Mitilini, quando na verdade ocupava essa posição porque era o único americano na ilha e prometendo que os destroyers americanos iriam dar cobertura durante todo o processo, 'sem tempo para maiores detalhes'.

${ }^{271}$ DOBKIN, op. cit., p. 194.
} 
Cartago, observando uma situação pela qual seus governos eram responsáveis. Não havia navios americanos em Cartago. Uma das mais agudas impressões que eu trouxe comigo de Smyrna foi um sentimento de vergonha por pertencer à raça humana","

Apesar de Kemal estar na cidade, Nureddin Pasha foi o nome do líder associado aos desmandos dos soldados. A maioria dos autores que recorrem aos arquivos turcos, quando tratam do assunto, trazem apenas a informação de que houve um incêndio e os bairros cristãos foram destruídos. Não fazem referência aos saques anteriores ao incêndio e nem aos refugiados no porto ou aos navios impávidos diante do desespero humano. Alguns afirmam que o fogo foi iniciado pelos soldados gregos em retirada, mas as tropas gregas haviam deixado a cidade antes que os turcos chegassem, vários dias antes do incêndio.

Depois de Esmirna, outras cidades da costa do Egeu tiveram que evacuar suas populações cristãs às pressas. A onda nacionalista turca reativou o ódio aos infiéis colocando suas vidas em perigo constante. Entre outubro e dezembro de 1922, sairam da Turquia mais de meio milhão de pessoas, com destino aos portos gregos. Algumas levavam poucos pertences ou valores, outras apenas suas roupas. Muitas crianças, muitas mulheres; pouca força de trabalho.

\subsection{3 - "Gran Finale" - A República Turca livre de cristãos}

O site do Museu do Genocídio em Yerevan traz a informação:

"A Catástrofe de Esmirna se tornou o ultimo episódio do Genocídio Armênio e o ponto de partida para a política estatal de 'Turquia para os Turcos' dos kemalistas"273

Infelizmente, precisamos discordar dessa afirmação. A destruição de Smyrna, com todo o seu peso moral, com a clara abstenção dos aliados mostrando o quão preocupados estavam os governos e a maioria de seus funcionários com relação às vidas humanas desperdiçadas ali, foi apenas o começo do fim. O desespero dos cristãos pelo resgate no cais de Smyrna repetiu-se em muitas das cidades da costa do Egeu e do Mar Negro. De todos os portos possíveis, saíam navios lotados de quantos gregos e armênios conseguissem subir a bordo.

De Ayvalik, outrora uma cidade próspera, de razoável tamanho, cujas plantações de oliva e tabaco forjaram muitas fortunas entre os gregos, os homens foram levados aos batalhões de trabalho e o restante da população fugiu para as ilhas a pouca distância da costa.

${ }^{272}$ HORTON, George. The Blight of Asia. London,Sterndale Classics, 2008, p.98. [grifo nosso]

${ }^{273}$ Fonte de internet: http://www.genocide-museum.am/eng/online_exhibition_16.php 


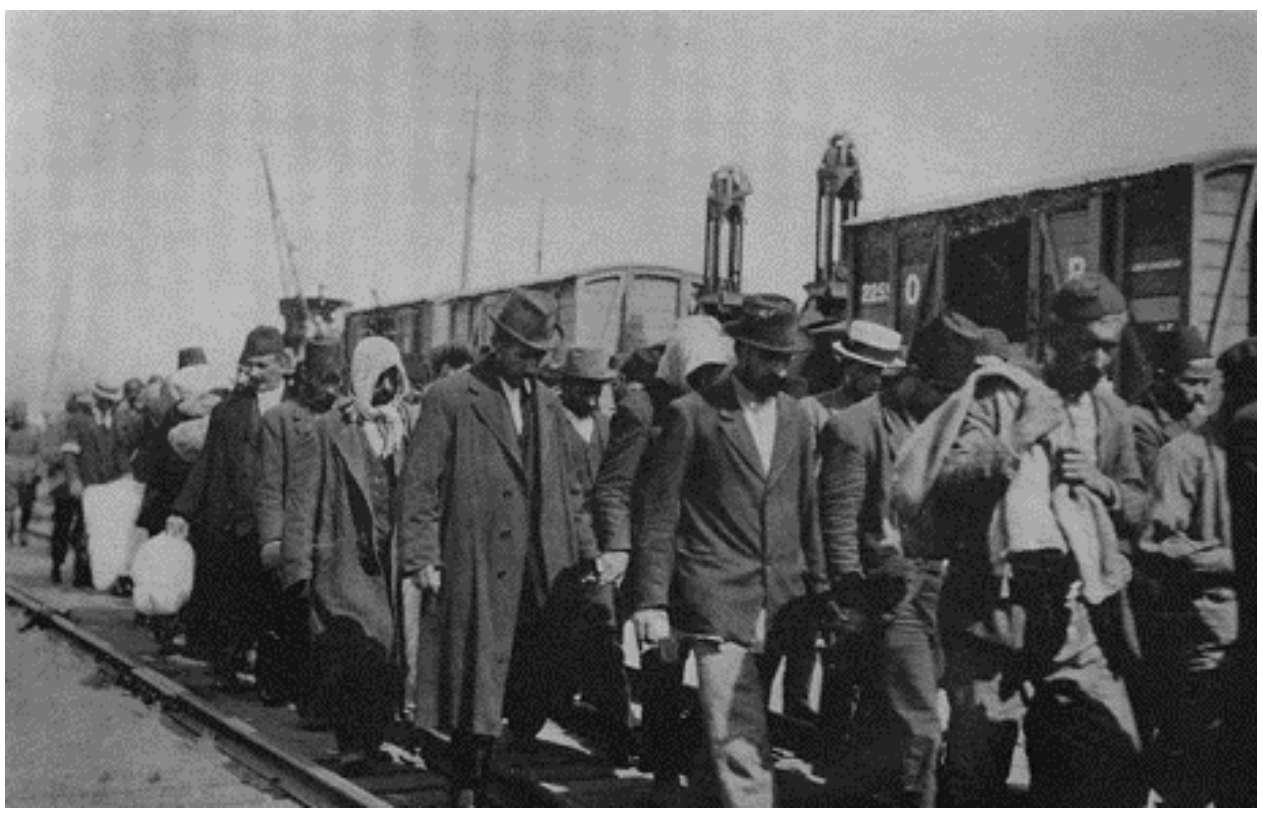

25 - Armênios e gregos presos e enviados para o exílio, Esmirna, setembro, 1922. AGMI Collection. Disponível online em http://www.genocidemuseum.am/eng/online_exhibition_16.php

O maior motivo para desespero era o ultimato de Kemal: em 30 de setembro todos os cristãos que ainda se encontrassem em solo turco seriam deportados para o interior, com destinos incertos. A essa altura, todos conheciam o significado desta ordem.

Enquanto gregos e armênios disputavam lugar nos navios de resgate, os governos aliados padeciam de outro tipo de desespero. Desde 15 de setembro, as tropas de Kemal haviam deixado Smyrna em direção ao norte, à ocupada Istambul. A intenção de Kemal era óbvia: estava determinado a seguir adiante com seu movimento nacionalista até alcançar todos os seus objetivos. Um deles era tomar de volta a capital do país. Vitorioso e vendo que seus antigos inimigos fugiam apavorados ou buscavam sua boa vontade, Kemal não tinha motivos para parar. Em 23 de setembro, suas tropas chegaram à zona neutra de Çanakkale (Península de Gallipoli), para horror dos ingleses reunidos do outro lado do arame farpado. Nesse mesmo dia, os aliados enviaram uma nota conjunta, na qual afirmavam "ver com favor" o desejo turco de recuperar a Trácia oriental, o terrritório a leste do Rio Maritza (Meriç), incluindo Edirne. Mas a área deveria permanecer neutra. Igualmente, os turcos podiam ter Istambul, mas somente após a assinatura do tratado de paz. ${ }^{274}$ Era uma meia concessão, importante, mas não o suficiente. As tropas kemalistas seguiram avançando, pressionando os ingleses e, apesar de nenhum dos lados ter disparado um tiro, o risco de confronto armado era evidente.

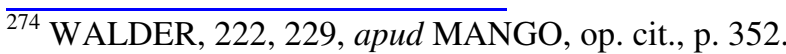


Em 28 de setembro, Franklin-Bouillon ${ }^{275}$ chegou a Smyrna com a notícia de que os aliados garantiriam a retirada dos gregos da Trácia Oriental: não apenas as tropas, mas também os civis, que somavam cerca de 250 mil. Finalmente, Kemal ordenou o 'auto' em 1 de outubro e as negociações para o armistício começaram em 3 de outubro, em uma reunião em Mudanya, onde encontraram-se três generais aliados, Harington, Charpy e Mombelli, ${ }^{276}$ com o representante enviado pelos nacionalistas, Ismet. O general grego Mazarakis se uniu a eles após algumas querelas. As negociações em Mudanya foram duras, pois os turcos estavam irredutíveis e demandavam a imediata posse da Trácia e a retirada dos gregos. Os britânicos preferiam uma transição contemporizada, com mais segurança. ${ }^{277}$

O Armistício foi assinado em 15 de outubro de 1922. Seu texto final garantia a retirada organizada da população grega da área reclamada, que deveria ser completada em 30 dias. Como consequencia imediata, começou uma imensa procissão:

"Quando à noite chegamos ao topo de um monte, eu pensei ver uma cidade inteira diante de meus olhos, com suas milhares de luzes - eram os campos [dos gregos] estendidos sobre as planícies, fogueira por fogueira, e eles dormiam no chão, sem abrigo de nenhum tipo ... Eles não sabem para onde vão e não vão encontrar abrigo quando chegarem." 278

Tamanha quantidade de refugiados dirigindo-se às já inchadas cidades gregas da Macedônia seria um imenso problema que não deixou de ser notado:

"Há 250 mil refugiados cristãos para serem evacuados apenas na Trácia Oriental... Perto de meio milhão já estão na Macedônia agora. Como serão alimentados, ninguém sabe, mas no próximo mês todo o mundo cristão ouvirá o apelo: 'Venha à Macedônia ajudar-nos.",279

Os termos do armistício já davam uma ideia do que estavam ainda por vir. Desde março de 1922, muito antes da vitoria sobre os gregos, Kemal havia enviado uma nota a Lorde Curzon, em que se dizia disposto a aceitar uma troca de populações para "ajustar" as dificuldades geo-demográficas em que viviam. Naquele momento não havia razão para considerar essa possibilidade. Curzon respondeu dizendo que seria muito complicado o transporte de tantas pessoas e que os gregos da costa do Egeu talvez não quisessem sair. ${ }^{280}$ Em outubro, a questão do 'desejo de sair' estava bastante resolvida. Por seu lado, Venizelos

\footnotetext{
${ }^{275}$ Diplomata francês, afirmava falar em nome dos aliados, mas os demais países não tinham notícia de sua incursão. Em pouco tempo, tornou-se grande amigo de Kemal.

${ }^{276}$ Representando respectivamente a Inglaterra, a França e a Itália. O representante grego a princípio não foi convidado.

${ }^{277}$ MANGO, op. cit., p. 353-354.

${ }^{278}$ Descrição de Fritjof Nansen, citada em CLARK, Bruce. Twice a Stranger - The Mass Expulsions that Forged Modern Greece and Turkey. Cambridge, Harvard University Press, 2006, p. 48.

${ }^{279}$ Trecho de notícia enviada por Ernest Hemingway, apud CLARK, idem.

${ }^{280}$ CLARK, idem, p. 58.
} 
racionalizava a condição de seu país, com 4,5 milhões de habitantes no total, receber mais de um milhão de refugiados, a maioria desprovidos de qualquer meios para sobrevivência. Como acomodar 700 mil na Macedônia? Para colocar de modo bem simples, a expulsão dos 350 mil muçulmanos que viviam ali seria uma opção. A chegada do Dr. Nansen ${ }^{281}$ com uma idéia bem semelhante era o que faltava para que a vela fosse acesa. Após trocar correspondências com Venizelos, diante do sinal verde desse último, Nansen foi a Istambul para tentar um acordo com os kemalistas. O acordo era uma questão delicada, pois os gregos já haviam saído ou estavam saindo, de uma ou de outra forma. A urgência da resolução era toda do colega grego e Kemal não parecia mesmo ter pressa nessa decisão.

Entretanto, o vazio populacional deixado principalmente na Anatólia era preocupante e o ingresso de alguma força de trabalho não faria mal. Além disso, a concordância permitiria que os governos envolvidos usufruíssem os 'benefícios' da expulsão unilteral, sem o opróbio moral de tal ato. Enfim, os dois países esperavam entrar em um bom acordo com relação a isso, bem antes de começarem as tratativas de Paz com os aliados. Porém, houve um 'pequeno' contratempo: Kemal entendia que as minorias cristãs não tinham lugar no país que estavam construindo. ${ }^{282}$ Portanto, o acordo deveria contemplar todos os gregos que viviam em território turco. Isso incluía a comunidade grega de Istambul, com mais de 300 mil pessoas, rica e poderosa. O lado grego não podia nem imaginar a possibilidade desses gregos serem também transformados em refugiados.

Além do acréscimo de mais esse número, a comunidade grega em Istambul tinha posses suficientes para ajudar a manter os refugiados do outro lado do Egeu. Refugiados, seriam apenas mais um enorme peso para a economia vascilante da Grécia. Para Venizelos, a cada dia aumentava a pressão por alimento e abrigo diante da chegada do inverno. Como descreve Clark,

"enquanto os diplomatas trocavam gentilezas em Lausanne, cada espaço público em Atenas e em Pireus, teatros, escritórios do governo, palácios reais, estava cheio de imigrantes destituídos e doentes" 283

De fato, não havia outro lugar para onde pudessem ir a não ser a Grécia, cujos portos e ilhas já ferviam com os refugiados da Anatólia. Segundo Dobkin, os aliados estavam indiferentes ao problema. O Dr. Nansen, ao tentar comprar alguns grãos abandonados para

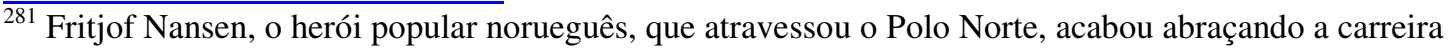
diplomática e dedicava-se, em nome da Liga das Nações, a resolver o problema dos apátridas, desde a Revolução Russa. Nansen abraçou também a causa dos expatriados gregos e turcos.

${ }^{282}$ CLARK, op. cit., p. 46.

${ }^{283}$ Idem, p. 64.
} 
ajudar os refugiados, encontrou oposição dos italianos e nenhuma ajuda dos franceses. $\mathrm{O}$ almirante americano Bristol, enviou telegrama ao Departamento de Estado dizendo que " $o$ governo grego devia se valer do trabalho voluntário de seu próprio país e nossas organizações de assistência não serem levadas a operar na Grécia". Bristol insistia para que a ajuda americana fosse destinada 'aos turcos deixados para trás'. O Departamento de Estado estava "inclinado a concordar". 284

Em dezembro, um surto de doenças pestilentas atingiu os navios que transportavam refugiados do Pontus, com tanta força que o governo grego fechou a imigração vinda dessa área. Vários navios ficaram então a meio caminho, com sua carga de desgraçados, sendo que muitos fundearam perto de Istambul ou em outros locais dos estreitos, esperando. Enviavam mensagens: "4 mil (5, 6 mil) refugiados. Sem água, sem comida. Varíola e Tifo a bordo."

O governo grego pediu ao Alto Comissariado Americano em Constantinopla que parassem os embarques de pessoas da Turquia, até que conseguissem organizar aqueles que já haviam chegado ou estavam a caminho. A resposta não foi a mais amistosa:

"se o governo grego persistisse em barrar os refugiados e estes continuassem se reunindo em Istambul e nos portos do Mar Negro, os oficiais turcos poderiam, 'com propriedade' deportá-los para o interior para prevenir epidemias - e o resultado de tais deportações já é bem conhecido para merecer comentários". ${ }^{285}$

Em janeiro de 1923, foi assinada a Convenção sobre a Troca de Populações Gregas e Turcas que, mais tarde, faria parte do Tratado de Lausanne. A convenção determina que os 'cidadãos turcos ortodoxos' que viviam na Turquia seriam relocados para território grego e os 'cidadãos gregos muçulmanos’ que viviam na Grécia, enviados para a Turquia. “Essas pessoas não poderão voltar a viver na Turquia e na Grécia, respectivamente, sem a autorização dos governos turco e grego, respectivamente". ${ }^{286} \mathrm{O}$ texto final da Convenção exclui da relocação compulsória os gregos de Constantinopla/Istambul e os turcos da Trácia Oriental. Todos os demais deveriam deixar suas casas, amigos, raízes e partir para outro país. Como a maior parte dos cristãos otomanos já estava na Grécia, a "troca" constituiu-se dos cerca de 250 mil cristãos remanencentes na Turquia e dos 350 mil muçulmanos da Grécia.

Decidida em janeiro e "agendada" para maio de 1923, o deslocamento de fato só começou em outubro. Além de adiar por tanto tempo o assentamento dos refugiados, houve

\footnotetext{
${ }^{284}$ DOBKIN, op. cit., p. 214.

285 DOBKIN, op. cit., p. 215.

${ }^{286}$ Trecho do artigo I da Convenção sobre a Troca de Populações Gregas e Turcas, de 30 de janeiro de 1923.
} 
mais uma consequencia grave: sem saber quando deviam sair, os muçulmanos não semearam os campos, comprometendo as colheitas nessas áreas. ${ }^{287}$

Mais de um milhão e meio de pessoas foram envolvidas nesse processo: 390 mil muçulmanos deixaram a Grécia de forma ordenada, com ajuda de uma comissão criada pelas provisões de Lausanne. Puderam levar os seus bens e receber pagamento pelos imóveis que deixavam. No total, 1.250.000 gregos e 100.000 armênios chegaram à Grécia, só um quinto deles sob as mesmas condições - um aumento de um terço em relação à população grega de antes da guerra. Os homens, chefes de família, ficaram retidos na Turquia. De acordo com os termos da convenção de Lausanne, deveriam ser liberados quando o tratado final fosse assinado, o que aconteceu em julho de 1923. Os poucos sobreviventes, entretanto, só chegaram à Grécia em janeiro de $1924 .{ }^{288}$

Alguns desses homens contaram suas histórias, aliás, muito similares ao que já ouvimos anteriormente:

“em grupos foram levados a pé até Magnésia, no interior da Anatólia. No caminho, os guardas tomavam seu dinheiro, seus sapatos, roupas, que vendiam aos aldeões das vilas por onde passavam. Estes aldeões, geralmente recebiam os prisioneiros com bastões, facas, adagas e armas. Às vezes atacavam aleatoriamente, outras vezes eram mais seletivos. 'Devo ressaltar que os turcos eram mais vingativos sobre os armênios', disse Bizdikian durante sua entrevista. 'Esse é um desses mistérios. Nós não sabemos porque era assim, mas era assim'. Ao chegarem a Magnésia, foram mantidos em um campo. Toda manhã eram levados à praça onde os moradores iam escolher alguns para trabalho escravo. Só os escolhidos eram alimentados."289

A assinatura de Tratado de Lausanne (24/07/1923) foi um ponto final e um recomeço. Para a Grécia, pôs fim ao sonho de ampliação do território acalentado desde a formação do país, um século antes; para a Inglaterra, foi o último suspiro da dominação política no Oriente Próximo; para a Turquia, a inauguração da nova República. Para os armênios, nada. O texto do Tratado sequer menciona os armênios. Lausanne praticamente atendeu a todos os itens do "Pacto Nacional" votado pelo governo provisório de Ankara, em 1919. A Turquia, isto é, Mustafa Kemal logrou conquistar tudo o que almejava, ainda que em detrimento de povos que há muito eram 'protegidos' pelos aliados, como é o caso dos armênios. Fica a questão: Por que? Que interesses impeliam os aliados a fazerem tantas concessões?

Essa pergunta segue sem resposta. Mustafa Kemal, a partir daí conhecido como 'Atatürk', pai dos turcos, tornou-se o primeiro Presidente da República da Turquia, cargo que ocupou durante 15 anos, até sua morte, em 1938. Como presidente, empenhou-se em

\footnotetext{
${ }^{287}$ DOBKIN, op. cit., p. 218.

${ }^{288}$ DOBKIN, op. cit., p. 219.

${ }^{289}$ Idem, p. 220-221.
} 
transformar seu país em uma nação moderna e ocidentalizada. Aboliu o sultanato e, em seguida, também o Califado. ${ }^{290}$ Pouco mais tarde, promoveu a reforma do alfabeto turco: os caracteres árabes foram trocados pos letras latinas. Essa medida, apontada como fundamental para a aproximação do país da comunidade européia, também é vista por muitos autores como uma forma deliberada de evitar ou dificultar o acesso à história pregressa do país. As novas gerações, a partir de 1928, não aprendem na escola a ler os caracteres árabes. Desta forma, a história pode ter sido silenciada e os perpetradores protegidos por ações estatais em nome do progresso.

Atatürk também fundou e manteve, inclusive com bens próprios, uma sociedade de pesquisa histórica, chamada 'Sociedade Histórica Turca', que Farrokh afirma ser uma reunião de historiadores revisionistas, com o objetivo de apagar o passado pouco glorioso dos novos heróis nacionais. ${ }^{291}$ Revisionista ou não, o fato é que a sociedade turca hoje está apenas começando a discutir seu passado, ainda com muito medo das represálias oficiais. A morte do jornalista Hrant Dink é um emblema das dificuldades encontradas pelos turcos que buscam a verdade sobre sua própria origem. Muitos foram presos ou ameaçados; outros vivem fora de seu país. O governo turco mantém a posição negativa, defensiva, apesar dos esforços internacionais, que discutiremos no próximo capítulo.

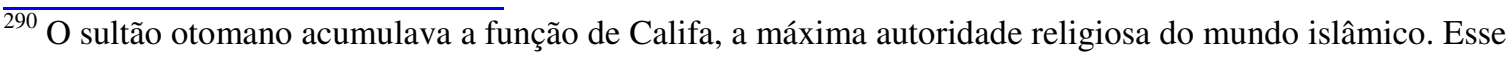
cargo foi extinto por Kemal, apesar das críticas severas dos governos dos países árabes.

${ }^{291}$ FARROKH, op. cit., p. 10.
} 


\section{III - ACORDOS E ACERTOS PÓS-GUERRA: A LUTA PELO RECONHECIMENTO}

\section{1- Armênios e gregos frente ao negacionismo}

Uma vez assinados os tratados e relocadas as minorias, o silêncio tomou conta do teatro de operações. Os turcos precisavam construir das ruínas um país totalmente novo, real apenas na fértil imaginação de Mustafa Kemal. Os gregos estavam ocupados em encontrar os bodes expiatórios de sua desgraça e descobrir uma fórmula para fazer caber em seu orçamento falido a recuperação das milhares de famílias sem esteio que se espalhavam pelas ruas e pelos campos. Os armênios, os poucos ainda vivos e que não fugiram, foram engolfados pelo turbilhão soviético e desapareceram do mundo ocidental por quase cinquenta anos.

Os armênios e gregos que se espalharam pelo mundo levaram também o seu tempo de recuperação física, emocional e econômica, durante o qual, provavelmente, o mais fácil era mesmo não lembrar, não pensar. Mas a memória de um povo é todo o seu tesouro e "não lembrar" é diferente de "esquecer". Nenhum armênio esqueceu a aniquilação, o terror, o desespero. Nenhum ser humano poderia esquecer a visão de um corpo de criança mutilado, de pilhas de corpos nus no meio das ruas. Com o tempo, o "não querer pensar" deu lugar ao sentimento de humilhação. O orgulho de uma nação, ferido, repisado, começa a pulsar novamente nas veias.

A campanha desenvolvida pelo governo de Kemal em prol do esquecimento desse "passado pouco louvável" dos heróis da nova república foi bem sucedida do ponto de vista turco. Como cita Coufoudakis,

“A política de turquificação foi construída a partir da xenofobia. No processo de criar uma nova Turquia e uma nova nação turca, Atatürk escreveu uma nova história e desenvolveu uma nova identidade turca e teoria linguística para se encaixar nos seus objetivos de sua 'nova' nação. A sua "Tese Turca da História (Türk Tarih Tezi) e sua "Teoria da Linguagem do Sol" de linguística (Güneş Dil Teorisi) apresenta a língua turca como a mãe de todas as línguas",292.

O povo turco se levantou, assumiu novas características e aprendeu a se aproximar do Ocidente. Essa mesma campanha, ainda hoje, alimenta o orgulho dos esquecidos. Na década de 1970, surgiram grupos clandestinos de armênios que orquestram uma série de assassinatos

\footnotetext{
${ }^{292}$ COUFOUDAKIS, Van. "From Lausanne (1923) to Cyprus (2009): Turkey's violations of International Law and The Destruction of Historic Hellenic Communities", in: SHIRINIAN, George N. (Ed). The Asia Minor Catastrophe and The Ottoman Greek Genocide - Essays on Asia Minor, Pontos and Eastern Trace, 1912-1923. Illinois, The Asia Minor and Pontos Hellenic Research Center, Inc., 2012, p. 251.
} 
políticos, durante quase dez anos. Conseguiram atrair a atenção para sua causa. Mas também conseguiram que o governo turco se torne ainda mais enfático em sua política negacionista. ${ }^{293}$

Para discutirmos a pertinência, a veracidade do "genocídio armênio e grego", antes de mais nada, é preciso discutir "genocídio". E essa é uma discussão árdua, que vem sendo feita desde o momento em que o termo foi cunhado. Nem mesmo a própria definição do termo é consenso entre os pesquisadores. Existem diversas definições, mais ou menos adaptadas para adequar o termo ao fato que se está tentando retratar.

A Organização das Nações Unidas (ONU), por exemplo, adota a seguinte fórmula:

"Genocídio está definido no Artigo 2 da Convenção para Prevenção e Punição do Crime de Genocídio (1948) como 'qualquer dos seguintes atos cometidos com a intenção de destruir, no todo ou em parte, um grupo nacional, étnico, racial ou religioso, tais como: matar membros do grupo; causar grave prejuízo físico ou mental a membros do grupo; infligir deliberadamente a membros do grupo condições de vida calculadas para levar a sua destruição física, no todo ou em parte; impor medidas com a intenção de prevenir nascimentos dentro do grupo; [e] transferir forçadamente crianças do grupo para outro grupo."294

Outros pesquisadores já utilizaram:

1- "Genocídio é a destruição deliberada de vida física de indivíduos humanos por serem membros de uma coletividade,295

2- "Genocídio é a tentativa bem sucedida de determinado grupo, investido de autoridade formal elou acesso preponderante ao poder, para reduzir por coerção ou violência letal o número de um grupo minoritário cuja exterminação seria desejável e útil e cuja respectiva vulnerabilidade é um fator importante que contribui para a decisão pelo genocídio" 296

3- "Genocídio é a destruição sistemática e estrutural de pessoas inocentes pelo aparato estatal ... Genocídio representa um esforço sistemático ao longo do tempo para liquidar uma população nacional, geralmente uma minoria ... [e] funciona como política fundamental para assegurar conformidade e participação do cidadão"297

293 ADALIAN, Rouben Paul. The Armenian Genocide: context and legacy. http://www.armeniangenocide.org/Education.56/current_category.117/resourceguide_detail.html

${ }^{294}$ Informação retirada do site de internet da ONU: www.un.org.

295 DROST, Peter, (1959) citado em JONES, Adam, Genocide, a Comprehensive Introduction. New York, Taylor \& Francis Group e-library, 2006, location 910 kindle fire reader

${ }^{296}$ DADRIAN, Vahakn, (1975) in JONES, op. cit., location 919 kindle fire reader.

${ }^{297}$ HOROWITZ, Irving Louis (1976), apud JONES, op. cit., location 919 kindle fire reader 
4- "Genocídio é a destruição planejada, desde o século 19, de um grupo racial, nacional ou étnico, pelos seguintes meios: a) seletivos assassinatos em massa de elites ou partes da população; b) eliminação da vida cultural e religiosa nacional (racial, étnica) com a intenção de 'desnacionalização'; c) escravidão, com o mesmo intuito; d) destruição da vida econômica nacional (racial, étnica), com o mesmo intuito; e) destruição biológica através de sequestros de crianças, ou prevenção da vida normal familiar, com o mesmo intuito. Holocausto é a aniquilação física, por razões ideológicas ou pseudo religiosas, de todos os membros de um grupo nacional, racial ou étnico." 298

5- "Genocídio no sentido genérico significa o assassinato em massa de número substancial de seres humanos, fora do contexto de ação militar contra forças militares de um inimigo declarado, em condições em que a vítima é incapaz de se defender."299

Como se nota nas definições citadas, cada autor prefere assumir determinada parte da definição, provavelmente aquela que poderá ratificar sua opinião a respeito de determinado caso. Existem muitas outras definições, de diversos autores. A maior parte deles refere-se ao Holocausto dos judeus sob o regime nazista, o mais discutido e documentado dos genocídios.

Persiste inclusive uma preocupação entre os pesquisadores de genocídio, a respeito da banalização do termo, caso seja aplicado a vários casos distintos. Ou seja, se qualquer intervenção estatal em que muitas pessoas percam suas vidas puder ser considerada genocídio, isso poderia enfraquecer ou diminuir a importância daqueles casos de genocídio 'mais importantes', pelo menos do ponto de vista legal. O caso dos judeus é, sem dúvida, o mais pungente, pela quantidade de vidas perdidas, pela quantidade de informação que o mundo recebeu a respeito e, até mesmo, pela localização do seu teatro de operações. A condição de derrotada da Alemanha Nazista também contribuiu para que o mundo pudesse ter acesso às informações sem grandes intermediários. Essa mesma condição de derrotada, a humilhação completa, permitiu que muitos alemães desejassem distanciar-se desse regime, odiá-lo e condenar suas ações. Permitiu-lhes assumir o passado desastroso e com isso, tentar limpar, ao menos parcialmente, as manchas do sangue de suas vítimas. Ainda assim, existem os que negam, os que aplaudem e os que procuram reviver a antiga glória.

\footnotetext{
$\overline{298}$ BAUER, Yehuda (1984), apud JONES, idem, location 943 kindle fire reader ${ }^{299}$ CHARNY, Israel (1994), apud JONES, ibidem, location 969 kindle fire reader
} 
Como já foi dito anteriormente em nosso estudo, nossa intenção não é discutir os aspectos legais do crime de genocídio, nem a respectiva relevância político-histórica de cada um dos casos. Nossa intenção com este estudo é discutir o peso moral de uma política de extermínio e, principalmente, da negação dessa política. Sendo assim, não faremos uma escala de 'importância' entre os genocídios modernos, reconhecidos ou não. Para nós, cada indivíduo implicado nesse tipo de política tem a mesma importância, enquanto uma vida que foi perdida, ou arrasada: cada vida conta.

Preferimos utilizar em nossa análise a definição da ONU, por ser 'mais oficial', e também porque nos parece mais completa. Entretanto, para uma discussão moral e/ou psicológica do assunto, não necessitamos de tantas palavras. O próprio termo "genocídio" é autoexplicativo. "Genos", em grego, povo + "Cídio", em latim, assassinato: "Genocídio" significa simplesmente "matar um povo".

É disso que falamos. Trata-se de um caso em que um ou muitos povos foram mortos!

Matar uma pessoa significa tirar-lhe a vida, mas no caso de um povo, de uma etnia, 'matar' não quer dizer necessariamente que todas as pessoas perderam suas vidas. Para matar um povo, também se pode apagar sua cultura, alterar as vidas das pessoas de tal forma que, a partir daquele momento, terão de reconstruir suas vidas, recriando suas raízes em outras terras. A memória de um povo que viveu um grande trauma, não importa quanto tempo passe, estará sempre marcada por aquele momento. Sendo assim, ainda que nem todos tenham perecido, o 'povo' renasce das cinzas de seus mortos. Persiste a lembrança do horror.

A história dos armênios, embora remonte quase três milênios, praticamente recomeçou em 1915. É uma nação nova, que (re)nasceu em meio ao desespero. Quando um historiador se propõe a estudar a história da Armênia, a primeira coisa que lhe vem à mente é o período de perseguição e morte. Não devia ser assim, pois a história da Armênia é rica em grandes feitos e delineada pela identidade desse povo. De um momento para o outro, entretanto, o mundo os reconhece como 'sobreviventes', 'refugiados' ou como 'traidores', dependendo da visão endossada.

O caso grego é mais difícil de explicar. O Estado grego estava constituído bem antes dos acontecimentos de que tratamos neste estudo. Nesse caso, poderíamos concluir que o 'povo' grego não teria sido afetado. Não? Antes de mais nada, é preciso fazer uma diferenciação importante: o 'povo grego' dos Bálcãs pouco tinha em comum com o 'povo grego' da Anatólia. As semelhanças estavam na religião e na língua, talvez remontassem a uma origem comum, vários séculos atrás, mas as trajetórias desses dois mundos já divergiam muito antes da revolução de 1821. Quando tratamos, ao longo deste estudo, das perseguições, 
das deportações e dos massacres de 'gregos', estamos nos referindo aos gregos da Anatólia, obviamente. Se hoje não existe virtualmente nenhum grego na Anatólia, cabe argumentar sobre seu destino. O que será que aconteceu ao 'povo' grego quando a Grécia (balcânica) recebeu a Grécia (otomana) e todos foram obrigados a conviver em um espaço exíguo? Qualquer um pode imaginar que o 'povo grego' atual é distinto daquele de um século atrás.

Essa argumentação nos leva a concluir que o 'povo turco' também passou pela mesma condição de morte traumática nesse período. É fato. Embora seja tabu admitir que os vitoriosos também sofreram, é preciso lembrar que milhares de muçulmanos foram expulsos da Macedônia pouco antes da Grande Guerra e precisaram integrar-se em um novo local. Da mesma forma, após a troca de populações, centenas de milhares de indivíduos foram forçadamente deslocadas para a Anatólia, pessoas que não falavam turco e cuja cultura era também diferente exigindo adaptação. Tais questões servem para demonstrar, ainda que fora do aspecto legal, que o momento histórico específico de que tratamos neste estudo abrigou não um, mas vários 'genocídios'.

A comunidade armênia da diáspora, principalmente, tem sido responsável por levantar e trazer a público a maior parte dos fatos indicadores dessa afirmação. Muitos autores se debruçaram sobre esse quebra-cabeças desde a década de 1970, começando por Vahakn Dadrian. É um trabalho árduo de enfrentamento às negações por parte do governo turco e seus simpatizantes. Encontramos em pesquisa na internet inúmeros sites dedicados a negar, item por item, as alegações armênias. ${ }^{300}$ Entretanto, é impossível desprezar a palavra de renomados pesquisadores dedicados a investigar a fundo a questão, apesar das ameaças recebidas, no caso dos autores de origem turca.

Como se expressou o professor Akçam, em uma conferência proferida em Geneva em junho de 2012: “o caminho para a paz e a democracia no Oriente Médio passa pelo

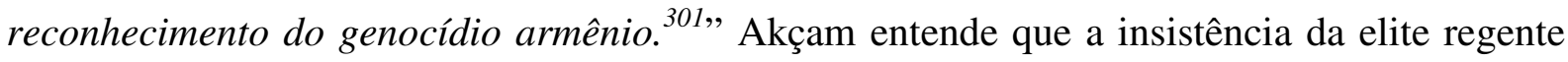
turca em evitar o debate sobre o genocídio armênio tem sua raiz na continuidade histórica que liga os atuais governantes aos perpetradores do massacre:

"Não houve um claro espaço entre eles, como aconteceu, por exemplo, na Alemanha. O moderno estado turco surgiu graças à ação direta das mesmas pessoas que sujaram as mãos com sangue armênio,"

\footnotetext{
$\overline{300}$ Existem muitos sites com conteúdo negacionista. O mais expressivo, em nossa opinião, é www.tallarmeniantale.com que traz várias citações e artigos, com comentários e se propõe a desmitificar com “fatos imparciais" o ‘chamado genocídio armênio'. Suas acusações de fraude e 'ghost-writers' armênios por trás de obras como o livro de Morgenthau, entretanto, não trazem qualquer referência documentada.

301 AKÇAM, Taner, in http://www.balcanicaucaso.org/eng/Regions-and-countries/Turkey/Taner-Akcam-to-talkabout-the-genocide-is-good-for-Turkey-118486

${ }^{302}$ AKÇAM, idem.
} 
É fato que imediatamente após a derrota em 1918, foram instauradas cortes marciais que julgaram os responsáveis pelos crimes cometidos durante a guerra. Em 2 de julho de 1919, o promotor público pediu a pena de morte para Talaat Pasha, Enver Pasha, Djemal Pasha, e Dr. Nazim, que já haviam fugido para a Alemanha nesse momento. ${ }^{303} \mathrm{O}$ próprio Atatürk afirmou que o que o CUP fez com os armênios foi "um ato vergonhoso"304. Julgar os culpados, segundo Akçam, teria sido uma calculada manobra política de Atatürk para obter um tratamento digno para um país derrotado. Pouco mais tarde, porém, os nacionalistas turcos perceberam que os aliados não pretendiam fazer concessões. E sem a respectiva compensação - o reconhecimento do território turco como um todo - não fazia sentido condenar culpados. Na mesma conferência o professor Akçam revelou ter verificado nos arquivos otomanos mais de 60 processos militares contra os responsáveis pelos massacres, o que sugere que o assunto não era um tabu na época. Em todos esses processos, os sobrenomes das testemunhas eram turcos.

"Se olhamos os documentos no arquivo do estado, descobrimos outra história da Turquia. É importante, para os turcos, que essas pessoas que foram testemunhas sejam honradas, que seus nomes sejam conhecidos. Não temos apenas assassinos, mas também heróis". 305

Os tribunais da Corte Marcial otomana foram instituídos por pressão inglesa. O ministro de relações internacionais Arthur Balfour pediu que o triunvirato do CUP fosse levado a julgamento junto com o rei Wilhelm II da Alemanha. ${ }^{306}$ Durante os julgamentos, conduzidos por autoridades otomanas, a acusação principal foi assassinato premeditado em massa, organizado pelo comitê central do CUP e executado pela Organização Especial. Os registros dos julgamentos podem ser encontrados no Takvim-i Vekayi, o jornal oficial do parlamento otomano. ${ }^{307}$

Após o desembarque grego em Esmirna em maio de 1919, o clima político mudou no Império Otomano. No verão de 1919, o governo de Damat Ferid caiu e um quadro prókemalista e menos simpático ao tribunal assumiu o governo. ${ }^{308}$ Com o crescimento da agitação nacionalista turca, aumentou também a desaprovação popular a tais julgamentos. Os

\footnotetext{
$\overline{303}$ The Scotsman, 2 de julho de 1919 , in http://www.umd.umich.edu/dept/armenian/bts/OCTOBER_7-21919_TS_TurkishCourtMartialPublicProsecutorsSpeech.pdf

${ }^{304}$ AKÇAM, Taner, A Shameful Act, op. cit., p. 12.

${ }^{305}$ AKÇAM Taner, discurso durante conferência em Geneva, op. cit.

${ }^{306}$ BALAKIAN, op. cit., p. 332.

${ }^{307}$ DADRIAN, V. A textual Analysis of the Key Indictment of the Turkish Military Tribunal Investigation the Armenian Genocide, in Armenian Review 44, no 1/173 (spring 1991), 3-4, apud BALAKIAN, op. cit., p. 334. ${ }^{308}$ BALAKIAN, idem, p. 339.
} 
britânicos mantinham cerca de sessenta prisioneiros turcos em Malta, na esperança de levá-los a um tribunal internacional, mas essa oportunidade não apareceu. Segundo Balakian, a política de negação do genocídio já se solidificava em 1920, em nome de um novo nacionalismo. $\mathrm{O}$ autor cita a resposta de Kiazim Karabekir a um ministro soviético com relação à entrega de uma porção da Armênia turca para a nova Republica Armênia:

"Na Turquia não houve nem uma Armênia nem um território habitado por armênios... Os armênios que vivem na Turquia cometeram assassinatos e massacres, e escaparam para o Irã, a América, a Europa e alguns para a Armênia. Como é possível chamar de volta esses assassinos e dar-lhes direito a voto?"309

Em 1921, por conta do assassinato de Talaat Pasha em Berlim, o assunto foi novamente levado à corte e muitos fatos e depoimentos vieram a público. Em ambos os casos, muitas provas foram apresentadas diante dos jurados que consideraram culpados os líderes do CUP, com especial referência à atuação de Talaat. O governo da Turquia afirma que as provas apresentadas foram forjadas por armênios e, com isso, alega não haverem provas suficientes para comprovar a intenção de matar. É sobre essa corda bamba que se apoiam ainda hoje, um século depois, os prós e os contras para o reconhecimento do crime de genocídio.

Ainda segundo Balakian, a partir da assinatura do Tratado de Lausanne em 1923, a política americana para com a Turquia também mudou, devido a interesses comerciais, principalmente por causa do petróleo, passando da assistência à negação. No mesmo ano, o Admiral Colby Chester escreveu no The New York Times Current History:

"os armênios foram removidos de áreas inóspitas onde não eram bem vindos e não podiam prosperar para as mais agradáveis e férteis partes da Síria... onde o clima é tão benigno quanto o da Flórida e Califórnia... e tudo isso foi feito com grande investimento de dinheiro e esforço."

Instituições educacionais e políticas governamentais promoveram coercitivamente as já citadas teorias de Atatürk para a criação de um 'novo' cidadão turco. O crescimento do Partido Democrata e a entrada de novos grupos na política no início dos anos 1950 permitiram um certo alívio nas pressões contra as minorias, mas o governo de Menderes enfrentou sérios problemas econômicos e políticos. A solução encontrada para desviar a responsabilidade foi reabilitar a ameaça comunista. Em 1955, ocorreu um pogrom contra os gregos de Istambul, uma demonstração de que as minorias pagariam o preço pela falha das instituições civis. ${ }^{311}$

\footnotetext{
$\overline{{ }^{309} \text { KARABEKIR, Isitkal Harbimiz, }}$ 736-37, citado em WALKER, Armênia, 305, apud BALAKIAN, ibidem, p. 375.

${ }^{310}$ CHESTER, Colby, “Turkey Reinterpreted”, Current History, (September 1922), 944, apud BALAKIAN, ibidem, p. 376.

${ }^{311}$ COUFOUDAKIS, op. cit., p. 251.
} 
Após um longo silêncio, em 1965, armênios rememoraram os "50 anos do Genocídio Armênio" em várias partes do mundo, utilizando o termo 'genocídio' explicitamente e, em 1966, foi publicado um artigo de Marjorie Housepian ${ }^{312}$, um primeiro sinal do renascimento da questão. A partir de então, novos pesquisadores se interessaram e também a mídia. A resposta turca foi de crescente hostilidade, com a contratação de especialistas em relações públicas para assumir essa campanha. Durante a década de 1970, o governo turco adotou medidas para pressionar a mídia a evitar a palavra 'genocídio'. Passou a empregar frases como 'o chamado genocídio armênio' e referir-se a esses fatos como 'guerra civil'. Em 1973 e nos anos seguintes ocorreram assassinatos de turcos, cometidos por armênios, o que serviu para azedar ainda mais as relações entre os dois países.

Citando Des Pres, Balakian afirma que há registro de que historiadores de várias universidades americanas receberam fundos do governo turco para apoiar o suposto 'outro lado da história'. O caso mais comentado de mudança de atitude em relação ao assunto é o do professor Bernard Lewis. Um dos mais importantes pesquisadores sobre a Turquia, Lewis usava na edição de 1962 de seu livro The Emergence of Modern Turkey, descrições como "o terrível holocausto... quando um milhão e meio de armênios pereceram" e, um pouco mais tarde, apresentava o ocorrido como "uma luta entre duas nações por uma só terra". 313

Em junho de 1998, a Associação de Pesquisadores de Genocídio (IAGS) aprovou uma resolução sobre o Genocídio Armênio e, em junho de 2000, enviou uma petição ao New York Times com o título "126 pesquisadores do Holocausto afirmam o fato incontestável do Genocídio Armênio e pedem que as democracias ocidentais o reconheçam oficialmente." Assinam a petição, entre outros, Elie Wiesel, Yehuda Bauer e Israel Charny. ${ }^{314}$ Em outubro de 2009, Roger W. Smith, presidente do Zoryan Institute ${ }^{315}$, escreveu sobre os protocolos assinados entre Turquia e Armênia ${ }^{316}$ :

"somos da opinião de que enquanto os turcos hoje não são culpados de cometer o Genocídio, eles são responsáveis por aceitar e permitir a negação oficial do Estado. A negação é considerada o último estágio do genocídio, que continua a vitimar os sobreviventes e seus descendentes, agravando uma ferida aberta que não pode cicatrizar. (...) O Genocídio Armênio é parte da história do mundo. Se queremos prevenir futuros

\footnotetext{
$\overline{312}$ HOUSEPIAN, Marjorie, "The Unremembered Genocide" in Commentary (February, 1966) apud BALAKIAN, op. cit., p. 379.

${ }^{313}$ DES PRES, On Governing Narratives, 253, apud BALAKIAN, idem, p. 381.

${ }^{314}$ BALAKIAN, idem, p. 385.

${ }^{315}$ O Instituto Zoryan (http://www.zoryaninstitute.org) é uma importante organização estabelecida em Toronto, Canadá, cuja finalidade é documentar, estudar e distribuir informação relativa a genocídio, diáspora e Armênia.

${ }^{316}$ Protocolos pelo estabelecimento de relações diplomáticas entre a Turquia e a Armênia. Assinados em 2009 e pouco depois inviabilizados, foram alvo de muitos protestos de pesquisadores, por conterem fórmulas que permitiriam um avanço da negação do genocídio armênio caso entrassem em vigor.
} 
genocídios, devemos tratar todos os casos de genocídio como parte da experiência universal, e da responsabilidade de todos." ${ }^{, 317}$

Vários países reconheceram o genocídio armênio, em especial a França, que enfrentou ameaças de rompimento de contratos multimilionários e aprovou uma lei de reconhecimento do Genocídio Armênio. Nos Estados Unidos, entretanto, as ameaças turcas parecem estar sendo mais eficazes: o governo turco conseguiu impedir que o congresso americano aprovasse um nota rememorativa dos 70 anos e depois dos 75 anos do Genocídio Armênio. O Presidente Obama, em 2008, afirmou publicamente seu compromisso com o reconhecimento do Genocídio Armênio quando fosse empossado, o que não aconteceu até hoje. As justificativas falam em 'não fomentar o desencontro entre dois países que estão conseguindo aproximar-se', mas certamente também pesa o fato da Turquia ser um aliado militar importante no cenário do Oriente Médio.

Ragip Zarakolu, editor turco e militante dos direitos humanos, afirmou que o julgamento de 1919 condenou à morte os mandantes e levou à prisão dezenas de oficiais responsáveis pela execução do plano das deportações. Os prisioneiros foram recolhidos à Ilha de Malta, onde os britânicos mantinham seus prisioneiros de guerra. Pouco tempo depois, entretanto, as autoridades britânicas liberaram esses prisioneiros, em troca de concessões acordadas com Kemal. Um dos prisioneiros liberados nesse momento foi Şükrü Kaya, o antigo comissário político responsável pelas deportações e que, mais tarde, tornou-se um dos ideólogos do Partido Republicano. O estatuto do Partido, segundo Zarakolu, teria sido copiado do estatuto do Partido Fascista. E após esse período, nunca mais houve um julgamento relacionado aos crimes cometidos em 1914-1918. ${ }^{318}$

Segundo De Zayas, o tratado de Sévres, assinado em 1920 mas não ratificado pelo governo provisório de Ankara, continha elementos preciosos para a compreensão dos fatos. Além do compromisso de julgar os oficiais turcos pelos crimes de guerra, também deveriam ser julgadas as autoridades turcas por crimes cometidos contra súditos do Império Otomano de diferentes etnias. Estava previsto ainda no texto do tratado o princípio da justa restituição para as vítimas:

"O governo turco reconhece a injustiça da lei de 1915 sobre propriedades abandonadas (Emval-I-Metruke) e suas provisões suplementares e as declara nulas e inválidas, no passado e no futuro. O governo turco se encarregará de facilitar ao máximo o retorno as suas casas e o restabelecimento dos negócios de súditos turcos de etnia não-

\footnotetext{
${ }^{317}$ SMITH, Roger W., The politics of Genocide and the Turkish-Armenian Protocols. Artigo disponível no site do Zoryan Institute: http://www.zoryaninstitute.org/news.html

${ }^{318}$ ZARAKOLU, Ragip, discurso durante o Seminário Internacional 95 Anos do Genocídio Armênio, realizado em 22-24 de Abril de 2010 no Departamento de História da Universidade de São Paulo.
} 
turca que foram forçados a abandonar suas propriedades por medo de massacre ou qualquer outra forma de pressão desde 1 de janeiro de $1914 .{ }^{319}$

Apesar de não ter nunca sido aplicado, o texto do tratado revela uma preocupação pelo reconhecimento e a punição de culpados por aqueles crimes. As provisões de Sévres - a responsabilidade do estado turco e a obrigação de providenciar restituição ou compensação, bem como a responsabilidade criminal individual - foram instituídas pelo Tratado que foi ratificado por todos os aliados e a Alemanha. Significa que as normas foram estipuladas, mas nunca foram implementadas porque o governo turco recusou-se a aceita-las e não houve pressão internacional naquele momento. ${ }^{320}$

Segundo Coufoudakis, no entre guerras e após a Segunda Guerra Mundial, a Turquia soube tirar proveito do isolamento dos Estados Unidos e da preocupação europeia com o fascismo e o nazismo:

"a Inglaterra, apesar dos protestos gregos com relação à violação do Tratado de Lausanne $^{321}$ no caso de Imbros e Tenedos, 'levou em consideração' as queixas, mas deixou de agir devido às condições da Europa no entre-guerras. Os Estados Unidos protestaram contra qualquer sanção à Turquia durante a Guerra Fria. Então, a Turquia prosseguiu com seu pogrom em Istambul em 1955, que John Foster Dulles atribuiu aos comunistas. ${ }^{322,}$

De Zayas afirma ainda que seria altamente recomendável que a Turquia apresentasse suas desculpas aos armênios, gregos e assírios, vítimas não apenas de perseguição e discriminação, mas também de genocídio, perpetrados tanto pelo Império Otomano quanto pelo novo Estado Turco. ${ }^{323}$ Tal afirmação é um caso raro na historiografia que trata desse tema. Raro por incluir os gregos e os assírios nesse contexto, como também, e principalmente, por incluir o Estado Turco, isto é, a República da Turquia, como perpetrador. A maioria dos autores prefere imputar responsabilidade apenas ao Império Otomano, sem citar a continuação das ações após a queda do Sultão. Só encontramos essa nova posição em obras publicadas a partir de 2010.

\footnotetext{
$\overline{319}$ American Journal of International Law 15. Supplement, Official Documents (1921): 235, apud DE ZAYAS, Alfred. The Ottoman Genocides in Light of the Genocide Convention in HOFMANN, op. cit., p. 317.

${ }^{320}$ DE ZAYAS, idem, p. 319.

${ }^{321} \mathrm{O}$ tratado determinou que as ilhas de Tenedos e Imbros, de população grega, localizadas na entrada dos Dardanelos fossem cedidas à Turquia, mas para proteger a população, a artigo 14 define medidas de proteção e isenção da troca de populações acordada com a Grécia.

${ }^{322}$ VRYONIS, The Mechanism of Catastrophe, 29, apud COUFOUDAKIS, op. cit., p. 255.

${ }^{323}$ DE ZAYAS, op. cit., p. 340.
} 
Como já foi dito anteriormente, após os julgamentos de 1919, não se falou novamente nesse assunto na Turquia. O cenário foi totalmente reconfigurado após a entrada em cena de Mustafa Kemal. Provavelmente por conta do espírito nacionalista e da veemência com que Kemal colocava a necessidade de se alimentar o orgulho nacional, a causa "Turquia para os turcos" conseguiu superar as questões de ordem menos prática, como os direitos das minorias.

Os acordos de Lausanne (1923) não tratam dessas questões. O Tratado final sequer menciona os armênios, mas um dos artigos nos chamou especialmente à atenção ao afirmar que:

"A Grécia reconhece sua obrigação de fazer reparações pelos danos causados na Anatólia pelos atos do exército grego ou administrativos que tenham sido contrários às leis de guerra. Por outro lado, a Turquia, em consideração à situação financeira da Grécia resultante do longo período em guerra e suas consequências, por fim, renuncia a toda exigência de reparação contra o Governo Grego." 324

Diante do ódio greco-turco analisado nos capítulos anteriores e diante do crescente orgulho nacionalista turco após a vitória retumbante sobre os gregos menos de um ano antes, nos parece difícil acreditar que o governo kemalista tenha realmente pensado em 'considerar a situação financeira da Grécia' nesse momento. Principalmente porque a Turquia também estava em frangalhos após o mesmo longo período em guerra. Ainda que seja somente uma especulação e uma provocação para futuros estudos, nos parece mais coerente que este artigo tenha sido fruto de um 'pacto de silêncio' entre as partes interessadas, no caso, Venizelos e Kemal. É fato conhecido que estes dois estadistas voltaram a negociar alianças pouco tempo depois, culminando com a visita de Venizelos a Ankara em 1930, para assinar um acordo de cooperação.

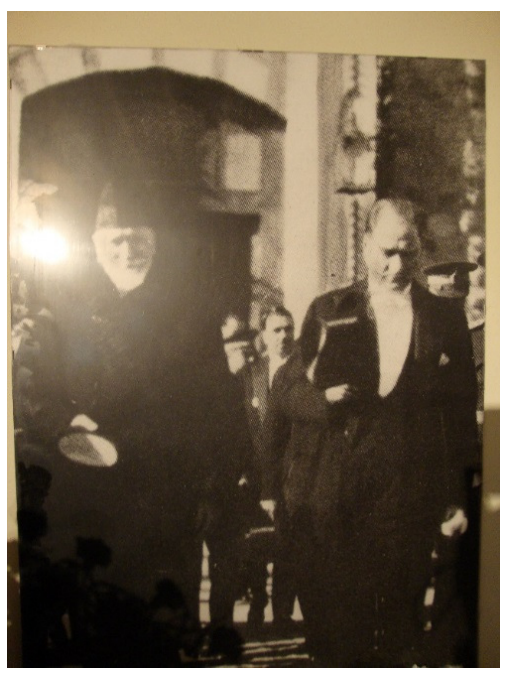

26 - O primeiro-ministro húngaro Conde Betlem e primeiro-ministro grego Venizelos, com Kemal Atatürk diante da Assembléia em Ankara, 29 outubro de 1930. Fotografia em exibição no Museu da Casa de Atatürk em Thessalônica, Grécia. Reproduzida por Ligia Sanchez, 2009.

\footnotetext{
$\overline{324}$ Artigo 59 do Tratado de Lausanne - retirado do site de internet: http://www.hri.org/docs/lausanne. [grifo nosso]
} 
É fato também que o governo grego manteve-se em silêncio a respeito dos massacres por um período bastante significativo. A primeira lei aprovada pelo congresso grego pelo reconhecimento do genocídio grego data de 1994. De acordo com Bruneau e Papoulidis, esse silêncio buscaria preservar as relações com a vizinha Turquia, conseguindo com isso não atrapalhar as potências ocidentais, que precisavam do apoio turco durante a Guerra Fria ${ }^{325}$. Coufoudakis ratifica essa afirmação ao citar a "timidez do governo grego, que durante as três primeiras décadas da Guerra Fria era fraco e dependia economicamente do apoio dos Estados Unidos. ${ }^{326}$

Somente a partir de 1970 é que as associações de refugiados teriam se tornado mais ativas no trabalho de cultivar a memória daqueles eventos, promovendo congressos internacionais da organização pan-pontiana em 1985, 1988, 1993, 1997 e 2002. O objetivo seria de obter desculpas formais do governo turco, de modo similar ao alcançado pelos judeus por parte da Alemanha.

Para demonstrar sua afirmação de que o governo kemalista prosseguiu com a política de 'limpeza étnica' com vistas à homogeneização do país, Coufoudakis cita o pogrom de 1955 e a invasão de Chipre em 1974. Segundo ele, tais violências foram levadas a termo com os mesmo elementos utilizados no passado: expulsão, deportação, intimidação, saques, bombardeios indiscriminados, assassinatos de civis a sangue frio, separação de famílias, tortura e batalhões de trabalho. Segundo o autor, a invasão de Chipre visava a partição da ilha com a criação de dois governos. Durante a operação, grande parte da herança cultural foi destruída, assim como aconteceu no passado. ${ }^{327}$

Em março de 1994, o congresso grego aprovou a lei que estabelece o dia 19 de maio como dia de "lembrança do genocídio contra os gregos do Pontus". Foi em 19 de maio de 1919 que Mustafa Kemal chegou a Samsun e a data marca a intensificação dos massacres contra gregos por milícias turcas. E, em outubro de 1998, o governo grego fixou a data de 14 de setembro como "lembrança do genocídio contra o povo grego da Ásia Menor". Este é o dia em que teve início o incêndio da cidade de Esmirna. Embora essas duas leis tenham sido aprovadas por unanimidade, a sua publicação aconteceu somente em 2001, o que demonstra que persiste ainda certa relutância do governo grego, devido às ligações com a Turquia. ${ }^{328}$

\footnotetext{
$\overline{325}$ BRUNEAU, Michel; PAPOULIDIS, Kiriakos.” Remembering the Genocide”, in: HOFMANN, op. cit., $p$. 353-354.

${ }^{326}$ COUFOUDAKIS, op. cit., p. 256.

${ }^{327}$ COUFOUDAKIS, op. cit., p. 262.

${ }^{328}$ BRUNEAU, op. cit., p. 355
} 
Ainda há muito o que ser feito pelo reconhecimento do Genocídio Grego, mas atualmente estamos vivendo momentos muito frutíferos de produção de conhecimento sobre este fato. Desde 2010, foram publicadas importantes obras que tratam da questão, sempre incluindo, além dos gregos, os assírios entre as vítimas de genocídio perpetrados pelo estado turco. Enquanto finalizamos este estudo, o parlamento australiano em New Wales aprovou em 2 de maio de 2013, uma moção de reconhecimento dos genocídios grego e assírio e reafirmação do genocídio armênio. ${ }^{329}$ Tais posturas demonstram que, mesmo após tanto tempo, o tema ainda é motivo de preocupação e pede (re)consideração. A negação contínua transforma o assunto em um tabu, algo que se molda a partir da mentira e deturpações propositais da História.

Segundo Israel Charny, existem vários segmentos de pessoas interessadas em apoiar a negação de um genocídio conhecido. Um fenômeno impressionante é o das vítimas de genocídio que procuram negar, minimizar ou ignorar outras vítimas do "seu" genocídio. O Professor Charny cita, por exemplo, os ciganos, soviéticos, homossexuais e testemunhas de Jeová que morreram nas câmaras de gás "dos judeus". Segundo ele, muitos judeus vítimas do nazismo não admitem com facilidade a existência destas outras vítimas e elas raramente são lembradas em eventos em rememoração do Holocausto. ${ }^{330}$

Seguindo essa linha de raciocínio, Charny relaciona esse fenômeno com o caso dos armênios e associando-o a sua própria experiência:

"Durante um seminário em Yerevan, de grandes intelectuais, a maioria armênios, mas também internacionais, em que um renomado pesquisador armênio dos Estados Unidos, que presidia uma sessão, propôs que o seminário reconhecesse oficialmente as vítimas arameas/assírias, gregas e yazidi do genocídio, juntamente com os armênios, e essa foi uma cena em que o inferno abriu suas portas.(...) A proposta foi derrotada naquele dia em Yerevan, não por voto, que acredito teria se mostrado pelo menos equilibrado, mas pela força da raiva e a veemência dos protestantes e insinuações, como já vi entre os judeus, de que aqueles que propõem tal reconhecimento são traidores da real causa Armênia." ${ }^{, 331}$

Essa mesma proposta foi colocada em discussão pela Associação Internacional dos Pesquisadores de Genocídio - IAGS e, ainda segundo Charny, então presidente da instituição, também ali houveram calorosos protestos de importantes pesquisadores, demandando documentação comprobatória, providenciada principalmente por Thea Halo e Adam Jones ${ }^{332}$.

\footnotetext{
${ }^{329}$ http://www.tert.am/en/news/2013/05/02/newwales/

${ }^{330}$ CHARNY, Israel W. "Integrity and Courage to Recognize All the Victims of a Genocide”, in: HOFMANN, op. cit., p. 29.

${ }^{331}$ CHARNY, op. cit., p. 32-33.

${ }^{332}$ HALO, Thea; JONES, Adam, "Notes on the Genocide of Christian Populations of the Ottoman Empire: Submitted in support of a resolution recognizing the Armenian, Assyrian and Pontic and Anatolian Greek Genocides of 1914-23" presented to the membership of the International Association of Genocide Scholars (IAGS), 2007, Sarajevo, Bosnia and Herzegovina, July 2007, apud Charny, idem, p. 35.
} 
A discussão prosseguiu por várias semanas e, mesmo após a aprovação pelo Conselho Executivo, houve tentativa de impedir que a resolução fosse levada a voto dos membros. De acordo com Charny, entre os opositores estavam incluídos pesquisadores respeitados por suas contribuições:

"Intrigantemente, a maioria deles estava ligada a uma mesma instituição e obviamente estavam unidos nessa decisão entre eles, o que levou alguns a questionar se haveria um financiador específico ao seu trabalho a quem procuravam conciliar, mas não havia qualquer informação que apoiasse essa conjectura e pessoalmente considero inconcebível que pesquisadores reconhecidos fossem suscetíveis a uma realpolitik econômica." 333

Por fim, após a determinação de mais tempo para que estudassem a questão, a Resolução IAGS 2007 foi finalmente aprovada, como segue:

"Considerando que a negação do genocídio é amplamente reconhecida como o estágio final de genocídio, conservando a impunidade para os perpetradores de genocídio e marcando o caminho para futuros genocídios;

Considerando que o genocídio Otomano contra as populações minoritárias durante e após a Primeira Guerra Mundial é geralmente citado como um genocídio contra Armênios apenas, com pouco reconhecimento dos genocídios qualitativamente similares contra outras minorias cristãs do Império Otomano;

Fica resolvido que é convicção da IAGS que a campanha Otomana contra minorias Cristãs do Império entre 1914 e 1923 constituiu genocídio contra Armênios, Assírios e Gregos do Pontus e da Anatólia.

Fica resolvido ainda que a Associação exige que o governo da Turquia reconheça os genocídios contra essas populações, expresse desculpas oficialmente e tome medidas significativas para a restituição."

A IAGS é uma instituição reconhecida mundialmente, da qual participam a maioria dos pesquisadores de genocídio. O fato de uma organização desse peso ter aprovado esse reconhecimento é um passo importante, mas cada passo adiante da comunidade internacional, geralmente corresponde a um passo atrás do governo turco. A negação oficial recrudesce e aumenta a repressão às vozes que se levantam.

\section{2 - Turquia: negação dos fatos e controle da história}

Os partidos neonazistas estão crescendo novamente, em todo o mundo, fato que deveria preocupar a todos que procuram meios para evitar novos genocídios. Entretanto, recentemente fomos informados de que os membros da Associação Internacional de Pesquisadores de Genocídio (IAGS) estão divididos, disputando poder entre si. Esta informação decorre de uma série de e-mails recebidos pelos associados, com relação à nova

$\overline{{ }^{333} \text { Charny não cita os nomes destes }}$ opositores 
eleição, ao cancelamento do contrato de publicação de periódicos com o Zoryan Institute e a mudança de foco da presidência. Israel Charny, um dos criadores da Associação, enviou recentemente uma mensagem pessoal aos associados, uma vez que seu artigo sobre o assunto foi vetado pela atual direção, declarando-se consternado pela disputa interna no IAGS, informando sua intenção de 'aposentar-se'.

Esse tipo de informação somente ratifica, em nossa opinião, a necessidade de uma discussão sobre genocídio que inclua a questão moral, a vida humana e seus indeléveis direitos, não importando as disputas acadêmicas e os embates personalizados.

O próprio Lemkin iniciou seus questionamentos após chocar-se com a "frequência do mal e acima de tudo, com a impunidade em que se apoiavam friamente os culpados" ${ }^{334}$. A impunidade que proporcionou tantas reedições do mesmo horror somente começou a ser enfrentada após a derrota dos nazistas. Ainda assim, com muita dificuldade, principalmente quando os 'culpados' estão do lado vitorioso. A discussão acerca da veracidade do Genocídio Armênio cruza justamente essa questão. Hoje existem alguns países cujos parlamentos reconheceram oficialmente o caso armênio como genocídio. São eles: Argentina, Bélgica, Canadá, Chile, Chipre, França, Alemanha, Grécia, Holanda, Itália, Líbano, Lituânia, Polônia, Rússia, Eslováquia, Suécia, Suíça, Uruguai, Vaticano e Venezuela. ${ }^{335}$ Apesar de figurar na lista, os Estados Unidos, mesmo após aprovar uma deliberação em março de 2010 assumindo o termo 'genocídio' para os massacres dos armênios durante a Primeira Guerra, ainda não empregam o termo abertamente. O forte protesto turco após a deliberação, inclusive com a retirada do embaixador que ameaçou cortar relações, teve seu peso e o presidente Obama segue chamando os fatos de "massacre".

A diplomacia americana tem motivos para evitar um confronto com o governo turco pois a Turquia tem sido um bom aliado. Funcionou como 'tampão' nos tempos da cortina de ferro e funciona também hoje como 'tampão' contra o avanço do Islã em direção ao Ocidente. Mais ainda, foi um aliado importante durante a guerra do Iraque, seguindo em posição de intervir nas questões de interesse para a América naquela parte do mundo. Esses são, sem dúvida, motivos consideráveis para que os Secretários de Estado se abstenham de pronunciar opinião. O governo turco sabe disso e procura apoiar-se nessa escora. No entanto, esses motivos não são bons o suficiente para calar manifestantes, nem para impedir que pesquisadores pesquisem, que autores escrevam e editores publiquem. Os últimos anos têm

\footnotetext{
$\overline{{ }^{334} \text { Lemkin, Raphael, apud Jones, op }}$. cit., location 1428 kindle fire reader.

${ }^{335}$ A lista está disponível no site: www.armenian-genocide.org, um dos mais atualizados e mais utilizados para informação sobre o genocídio armênio.
} 
sido prolíficos nesse aspecto. Mesmo diante de perigo real, alguns estudiosos, inclusive turcos, levantam suas vozes tentando desmistificar o passado incômodo de seu país.

O editor e ativista político Ragip Zarakolu, ao apresentar a premiação "Freedom to Publish", iniciativa que premia autores, editores e distribuidores turcos que publicam livros 'proibidos' na Turquia, cita alguns dos casos de recente perseguição estatal contra intelectuais turcos. Zarakolu foi preso e recolhido a uma prisão de máxima segurança em 1 de Novembro de 2011 (um mês depois de ter feito o comunicado abaixo) e liberado em Abril de $2012^{336}$. Em Janeiro desse ano, havia sido indicado ao Prêmio Nobel da Paz.

"Todo ano, desejamos que a Turquia se torne um país em que escrever e criar, o direito dos editores de disseminar esses escritos e obras, o direito do público de receber informação e ler não seja mais limitado, e então estes prêmios não serão mais necessários. Apesar dos nossos desejos, as condições não melhoram e vários incidentes nos levam a entregar novamente esta premiação. Temos testemunhado diversos esforços para reduzir a liberdade de pensamento e expressão. Em janeiro de 2011, grupos atacaram e ameaçaram livrarias em Istambul por vender o calendário 2011 com o tema "Racismo, Discriminação e Crimes de Ódio", publicado pela editora Métis. Ainda em janeiro, o Primeiro Ministro Erdoğan chamou de 'monstruosidade' o Monumento à Humanidade de Mehmet Aksoy em Kars e pediu que fosse demolido, o que de fato está sendo feito.

No final de março, Orhan Pamuk foi condenado a pagar seis mil liras turcas como indenização a seis pessoas, devido a sua declaração 'nós matamos 30 mil curdos e um milhão de armênios' feita a um jornal Suíço, o que abre precedente para que todos os cidadãos turcos o processem. Ele só foi salvo de pagar indenização a milhões de pessoas devido a um estatuto de limitação.

Enquanto isso, não satisfeita em bloquear milhares de sites de internet, a Autoridade de Tecnologias de Informação e Comunicação decidiu introduzir um filtro para prevenir livre acesso à internet. A outra agencia reguladora, Alto Conselho de Telecomunicações (TIB) enviou uma lista de palavras a serem bloqueadas para as empresas servidoras, que nenhum domínio incluindo essas 132 palavras deveria ser acessado.

A lista de autores julgados em cortes marciais durante os anos do golpe militar (década de 1970) por seus livros, traduções e mesmo caricaturas inclui nomes como Mete Tunçay, Atilla Tokatlı, A. Kadir, Müjdat, Gezen, Savaş Dinçer, Asım Bezirci, Atilla Tokatlı, Yaşar Miraç, Pınar Kür, Adalet Ağaoğlu, Demirtaş Ceyhun, Emil Galip Sandalcı.

Em 1983 a nova Lei de Imprensa passou a responsabilizar também editores pelas publicações, o que suscitou um protesto dos editores e estes ficaram com a missão da autocensura. Após 1980, os editores não se atrevem a publicar livros sobre socialismo e nem pensam em publicar livros sobre a questão Curda ou os eventos Armênios.

Como se as restrições já existentes não fossem suficientes, o Governo de Özal estabeleceu uma Banca para a Proteção de Crianças contra Publicações Perigosas, que passou a trabalhar contra as obras de literatura.

O jornalista Nedim Sener, por seu livro 'Assassinato de Hrant Dink e as Mentiras da Inteligência', enfrentou acusações como 'tentativa de influenciar a justiça de um julgamento', 'violação de segredo de comunicação interpessoal', 'expor como alvos os que lutaram contra o terrorismo'. Muitos jornalistas estão em julgamento com acusações similares e milhares de casos.

Um desdobramento muito negativo foi a inclusão do Artigo 301 como base para indenização pessoal.

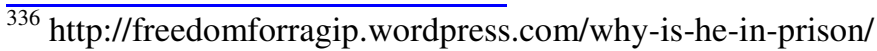


Como foi dito por Öztürk Özdoğan, presidente da Associação dos Direitos Humanos, 'infelizmente, um sistema judiciário realmente neutro e independente que iria legalizar os modernos princípios de lei penal baseada na regra da lei ainda não existe na Turquia'. De fato, o judiciário nunca foi uma força independente apoiada na lei e nos direitos humanos na Turquia. Ele sempre esteve sob a tutela do Executivo.,"337

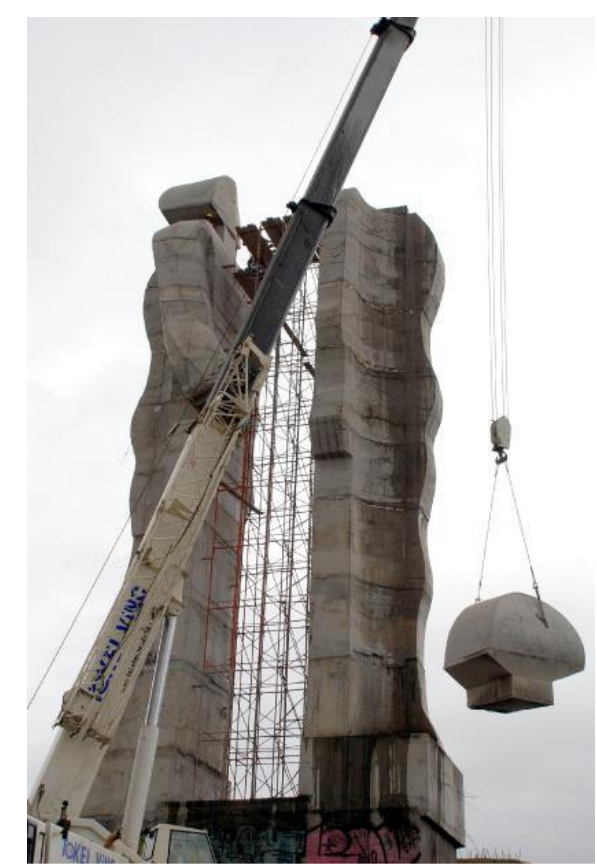

27 - Demolição do Monumento à Humanidade, de Mehmet Aksoy, em Kars. De acordo com o escultor, sua obra mostra a dor da divisão entre Turquia e Armênia e promove a paz, irmandade e reaproximação entre os dois países. Imagem disponível em http://www.armenianweekly.com/2011/05/11/ ucubedecapitated-in-kars/

O Artigo 301 do Código Penal Turco é muito citado por todos os ativistas de direitos humanos interessados nesse tema. É um artigo bastante controverso, que já recebeu diversas emendas desde quando foi redigido em 1926, sendo que a sua 'nova versão' foi introduzida por um pacote de reforma penal que antecedeu a abertura de negociações para a entrada da Turquia na União Europeia. Nesse artigo está descrita a punição para aqueles que "denigrem a turquicidade". A tradução de "turkishness" para o português não é fácil, mas a ideia é simples: um cidadão turco não pode declarar ou escrever algo que possa diminuir a grandeza nacional turca. O Artigo 301 assim determina:

“1. Uma pessoa que publicamente denigra a Turquicidade, a República ou a Grande Assembleia Nacional da Turquia, deve ser sentenciada a pena de prisão de 6 meses a 3 anos.

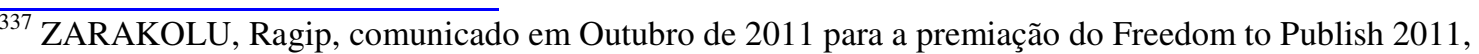
disponível em http://www.internationalpublishers.org/images/stories/FtP/ReportsLetters/2011_report_on_the_ freedom_of_publication_son.pdf
} 
2.Uma pessoa que publicamente denigra o Governo da República da Turquia, o corpo judiciário do Estado, as organizações militares ou de segurança, deve ser sentenciada a pena de prisão de 6 meses a 2 anos.

3. Se a ofensa à Turquicidade for cometida por um cidadão turco em outro país, a pena imposta deve ser aumentada em um terço.

4. Expressões de pensamento com a intenção de crítica não constituem crime." 338

Por conta desse artigo, por exemplo, o prêmio Nobel Orham Pamuk foi julgado, como relatado anteriormente. Pela mesma razão, Elif Şafak foi julgada por seu livro Father and Bastard, em que consta a seguinte passagem: "Eu sou a neta de sobreviventes do genocídio, que perderam todos os seus parentes nas mãos dos açougueiros turcos em 1915, mas eu mesma sofri lavagem cerebral para negar o genocídio porque fui criada por um turco de nome Mustafa."

Vários autores e ativistas políticos, como Ragip Zarakolu, questionam a existência de tal artigo no código penal de um país que pretende ser democrático. Esse pensamento unido ao que já foi dito sobre a censura à imprensa pode levantar alguma suspeita de que existe algo que o governo turco deseja manter em segredo. De acordo com Coufoudakis, a Turquia tenta explicar e defender suas ações que levaram à eliminação quase completa das minorias com racionalizações:

“- a deslealdade dos grupos minoritários - armênios e gregos eram vistos como 'quinta coluna' dentro do império e, mais tarde, na República;

- a necessidade de trazer união e coesão ao Estado Turco através da recuperação do controle econômico;

- a ameaça do comunismo (por exemplo, o Primeiro Ministro Menderes tentou atribuir o pogrom de 1955 ao banido Partido Comunista Turco);

- a negação: as ações atribuídas aos líderes turcos são forjadas e pretendem arruinar o país e seu prestígio;

- medidas tomadas em represália aos atos de terceiros. A expulsão em 1964 dos gregos de Istambul foi justificada pelos eventos em Chipre."

Por fim, para encontrar a mais pormenorizada explicação de todos os eventos de 1915, basta buscar na página do Ministério de Relações Exteriores da Turquia, a seção 'Frequent Asked Questions'. ${ }^{339}$ Não há, entretanto, referência ao que aconteceu após esse ano com as minorias cristãs. No site do Centro Cultural Brasil-Turquia, com sede em São Paulo,

\footnotetext{
$\overline{338}$ ALGAN, Bulent. The Brand New Version of Article 301 of Turkish Penal Code and the Future of Freedom of Expression Cases in Turkey. German Law Journal, v. 9, nº. 12, p. 2237-2238.

${ }^{339} \mathrm{http}: / /$ www.mfa.gov.tr/questions.en.mfa
} 
encontramos referências aos terroristas armênios e a afirmação de que "foram transferidos não por causa de sua raça, etnia ou religião, mas por causa de suas atividades militantes"340.

Curioso notar que, em nenhuma dessas fontes oficiais de informação, existe referência aos depoimentos dos sobreviventes, dos diplomatas e agentes de assistência que testemunharam tais fatos. Mas a informação de que não foi encontrado nenhum documento que comprove a intenção estatal de matar está em toda parte. Importante também notar que tais fontes não citam os fatos ocorridos após a fundação da República da Turquia, que, a nosso ver, são nada menos que uma continuação, sem interrupção, da mesma política de extermínio das minorias em prol da homogeneização social do país.

Apesar de não existirem provas irrefutáveis da 'intenção de matar', entendemos que estas são desnecessárias para concluir-se que era essa a intenção. Não é possível imaginar que um líder político, por mais alienado da realidade que estivesse, pudesse pensar em ordenar tais marchas sem perceber que isso resultaria na morte da maior parte das pessoas. Ou que ordenasse a liberação dos condenados das prisões para auxiliar em uma operação estatal e não atinar que estes tinham poucos motivos para ajudar voluntariamente o governo. Da mesma forma, entendemos que o confronto das 'alegações' com as 'negações' pode prescindir de provas documentais. Não haveria razão para a promulgação de leis que restringem o acesso popular a sites de internet ou a publicação de livros; não haveria razão para punir com prisão o uso da palavra genocídio, se não houvesse algo a ser escondido, a ser esquecido. Infelizmente, a contínua negação do passado mantém como reféns da História tanto os armênios como os gregos e os turcos.

\section{3- Consequências do Negacionismo}

Não é de surpreender que uma grande parte dos pesquisadores de genocídio tenha formação em psicologia. O que surpreende é que suas descobertas façam pouco efeito no processo de reconhecimento do genocídio. O trauma psicológico das vítimas tem características específicas, reconhecidas pela comunidade científica, porém não serve como testemunha de acusação.

\footnotetext{
$\overline{340}$ http://www.brasilturquia.com.br/index.php/a-turquia--informacoes-gerais/historia-otomano-turquiaregiao/alegacoes-infundadas-dos-armenios
} 
Para que a comunidade internacional se mobilize para pressionar pelo reconhecimento é preciso que as vítimas apresentem documentos. Mais que isso, é preciso que possam provar que os documentos não são forjados. Não bastam as vozes de milhares de testemunhas, não bastam as evidências como a montanha de ossos espalhada pelo deserto ou os escombros de igrejas queimadas com centenas de pessoas dentro. Não bastam as palavras de diplomatas estrangeiros, não bastam as fotografias. É necessário apresentar documentos!

E se até hoje tais "provas" não foram apresentadas, daqui para a frente, menor será a probabilidade de que essas provas apareçam. Portanto, o melhor seria "esquecer o passado e seguir em frente..." Segundo Herman, essa é uma das frases muito utilizadas pelos negacionistas de genocídio, assim como 'isso nunca aconteceu' ou 'estão mentindo ou exagerando'. As versões das vítimas tornam-se “alegações, sentimentos, reclamações ou rumores, sugerindo que pessoas que sobrevivem a atrocidades podem não ser capazes de contar suas histórias de modo coerente. Sobreviventes geralmente se expressam com muita emoção, as vezes de forma contraditória e fragmentada, e isso é usado por outros para diminuir a sua credibilidade." 341

Os eventos de 1915, entretanto, ainda são a maior razão para que os armênios se encontrem no meio de suas rotinas de vida. A celebração do último 24 de maio em São Paulo reuniu dezenas de armênios que raramente se apresentam nos demais eventos da comunidade. E é assim que acontece em muitas partes do mundo: esta não é uma atitude isolada. As pessoas mobilizam-se em nome do reconhecimento do genocídio muito mais do que fariam por qualquer outra questão cívica. De acordo com Alayarian,

"para muitos armênios, a sua identidade está associada à cultura de violência ou de violação, ao invés de sua cultura original. O modo como interagem com sua cultura está muitas vezes influenciado por sentimentos associados à perda, raiva. Muitas vezes, especialmente para aqueles que vivem na Turquia mas têm sobrenomes armênios, há uma percepção de ser um pária, alguém que é de alguma forma suspeito e portanto, em risco". 342343

Em uma análise psicológica, poder-se-ia dizer que essa forma de ver a si mesmo está ligada à inadequação que deriva da ausência do luto. A contínua negação do genocídio impede que os sobreviventes vivenciem as suas perdas e chorem por seus mortos. Com isso, ficam permanentemente presos àquele momento, não sendo capazes de compreender, nem de

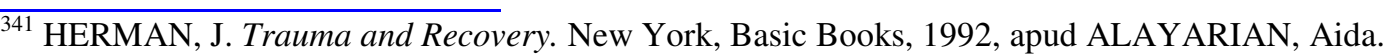
Consequences of Denial - The Armenian Genocide. London, Karnac Books, 2008. Loc 861 kindle reader.

${ }^{342}$ ALAYARIAN, op. cit., location 272 kindle fire reader.

${ }^{343}$ Esta última afirmação nos foi confirmada em uma conversa com uma tradutora brasileira, casada com um turco, que preferiu não ser identificada. A tradutora nos relatou que vive em Istambul e que tem alguns amigos armênios. Quando perguntamos como vivem essas pessoas hoje, na Turquia, ela respondeu: "normalmente, mas com medo".
} 
libertar-se do trauma para seguir vivendo. Esta situação está relacionada também aos turcos. Alayarian mostra que em um genocídio, a crueldade mais característica é a mentalidade coletiva, que requer uma cooperação de grupo, organização e união para torturar, assassinar e destruir. Para unir-se a esse tipo de constituição, o indivíduo coloca-se em uma tal condição que lhe permite representar as repressões de seus próprios impulsos instintivos de uma forma “socialmente aceitável”. Sendo assim, pode ser visto como herói e não como criminoso. ${ }^{344}$

Ao participar de genocídio, o indivíduo age enquanto membro do grupo, e essa identificação requer fortes laços emocionais. No caso dos armênios e turcos, essas ligações ainda estão presentes, reforçando a necessidade de pertencer a um grupo ou ser parte de uma sociedade. De acordo com Bion, "para pertencer a seu grupo, o indivíduo precisa seguir, ou fingir que segue, o superego do grupo, suas crenças e funções."

Para Cox, antes de interpretar os motivos da negação, é preciso levar em conta a diferença teológico-cultural com relação ao reconhecimento da culpa em uma cultura de raiz judaico-cristã e outra que preza os conceitos de vergonha e honra. Segundo a autora, a primeira se contrapõe ao pecado e à culpa, a possibilidade de arrependimento, o perdão e a reconciliação, enquanto que em culturas como a islâmica, as respostas mais adequadas à culpa são a expiação e a punição, pode-se verificar reflexos dessa visão nas chamadas "violências em nome da honra". A autora define como um grande desafio para o povo turco encontrar um modo apropriado de reconhecer essa evidência massiva de culpa e vergonha. ${ }^{346}$

Como já citamos anteriormente, alguns autores, como Akçam, atribuem a negação oficial turca ao fato de que os perpetradores seriam os mesmos heróis nacionais, o que parece coerente com a explicação psicológica sobre a vergonha. Quaisquer que sejam as razões, devem ser consideradas como importantes, uma vez que o governo turco dispende esforços nessa direção.

Um desafio ainda maior deve colocar-se para os pesquisadores de grande renome que se esforçam pelo reconhecimento de um genocídio quando alguns de seus colegas procuram negar os mesmos fatos. Como já vimos, existem instituições de pesquisa americanas cujos pesquisadores recebem verba do governo turco para escrever a história daquele país. Em um artigo para o Holocaust and Genocide Studies, três grandes pesquisadores de genocídio discorrem sobre como o embaixador turco nos Estados Unidos 'contratou' os serviços de um outro pesquisador americano - Dr Heath W. Lowry - para levantar 'possíveis riscos' nas obras

\footnotetext{
${ }^{344}$ Idem, location 1523 kindle fire reader.

${ }^{345}$ BION, W. R. Learning from Experience. London, Heinemann, 1962a, apud ALAYARIAN, ibidem, location 1536 kindle fire reader.

${ }^{346}$ COX, Caroline, citada em ALAYARIAN, op. cit., location 158 kindle fire reader.
} 
de autores que citam o genocídio armênio e como neutralizar essas ameaças. $\mathrm{O}$ artigo apresenta documentos contidos em uma correspondência enviada para Robert Lifton, que incluem uma carta assinada pelo embaixador turco, em que pede que "o autor seja mais cuidadoso ao citar 'de modo descuidado' fatos que desconhece". Refere-se a algumas referências a Dadrian feitas pelo autor em seu livro The Nazi Doctors, Medical Killings and the Psychology of Genocide. ${ }^{347}$

O memorando escrito por Lowry “indica que ele tem estado engajado em uma relação com o governo turco e que tem oferecido conselhos regularmente sobre a negação, tanto para o embaixador turco para os Estados Unidos quanto para outras pessoas na Turquia"348 De acordo com estes autores, algumas das formas pelas quais a negação de genocídio causa "violência a outros" foram identificadas por Israel W Charny em seu artigo The Psychology of Denial of Known Genocides, no qual enfatiza que a negação oculta o horror dos crimes e isenta da responsabilidade por isso. Esse ponto é ratificado por Deborah Lipstadt, que escreve que "negação busca reformar a história para reabilitar os perpetradores e demonizar as vítimas". 349

Negar, de acordo com Charny, "ataca o espírito e a moral histórica" dos sobreviventes e descendentes dos mortos e coloca "maiores cargas em sua recuperação". Em resumo, negar impede a recuperação das feridas infringidas pelo genocídio. Mais ainda, constitui um "ataque à identidade coletiva e continuidade cultural nacional do povo vítima". ${ }^{350}$ Ainda segundo os mesmos autores, a negação de genocídio é uma ofensa que permite contribuir para a violência genocida. A negação contribui para o genocídio pelo menos de duas formas: primeiro, o genocídio não termina com a última vítima; a negação continua o processo de morte. Mas se essa negação aponta para o passado e para o presente, também tem implicações para o futuro. Absolvendo os perpetradores dos genocídios passados de sua responsabilidade e borrando a realidade do genocídio como uma forma de política de estado largamente praticada no mundo moderno, a negação pode aumentar o risco de novos genocídios futuros. $^{351}$

\footnotetext{
${ }^{347}$ SMITH, Roger; MARKUSEN, Eric; LIFTON, Robert J. Professional Ethics and the Denial of the Armenian Genocide. Holocaust and Genocide Studies, V9 N1 Spring 1995, p. 5.

${ }^{348}$ Idem, p. 6.

${ }^{349}$ CHARNY, Israel W, "The Psychology of Denial of Known Genocides," in CHARNY, ed., Genocide, 2:23 and LIPSTADT, Deborah E, Denying the Holocaust The Growing Assault on Truth and Memory (New York. The Free Press, 1993), p. 217, apud SMITH, op. cit., p. 13.

${ }^{350}$ CHARNY, Israel W, "The Psychology of Denial of Known Genocides, idem, p.13.

${ }^{351}$ Ibidem, p. 14.
} 
Com relação aos pesquisadores que apoiam o negacionismo, os autores do artigo citam novamente Charny, que identificou nas respostas de vários estudiosos a um determinado questionário, "mecanismos de defesa do pensamento" que favorecia a "negação do genocídio". Esses mecanismos incluíam o que o autor chamou de "cientificismo a serviço da negação", ou seja, a alegação de que não haveria evidencia empírica suficiente para justificar uma posição inequívoca da realidade do genocídio; e "definicionalismo" isto é, reconhecimento das mortes, mas negação de que seriam produto de "genocídio", desviando portanto a responsabilidade do governo turco e trivializando a morte de mais de um milhão de armênios como resultado da fome, guerra e doenças. ${ }^{352}$

Em nossa opinião, uma das mais graves consequências do negacionismo é a perpetuação do ódio. Hoje, no século XXI, ano 2013, cem anos depois, muitas relações entre turcos e armênios ou turcos e gregos ainda são regidas pelo ódio mútuo. Em uma conversa despretensiosa com um armênio, citamos a intenção de visitar a Turquia. A resposta imediata, sem ao menos tomar fôlego, foi um "para quê?", cheio de desprezo. Em outra ocasião, fizemos uma palestra no Centro de Estudos Helênicos Areté, em São Paulo, cujo título era "Gregos Otomanos". A plateia, 90\% descendentes de gregos, reagiu quase em uníssono ao primeiro slide: “não existem gregos otomanos!!”.

O documentário de Nefin Dinç, The Other Town - why do nations clash?, realizado em 2011, sobre um grego nascido na Turquia e que se mudou para a Grécia com os filhos pequenos, mostra essa realidade de modo bem evidente. Quando os filhos iam à escola na Turquia, aprenderam nas aulas de história que os gregos foram muito maus, que destruíram muitas coisas, etc.. Ao se mudar para a Grécia e matricular os filhos em uma escola grega, descobriu que a história ali era outra. Os turcos era opressivos e faziam os gregos de escravos... O mesmo documentário traz entrevistas com habitantes de duas cidades, uma no interior da Turquia e outra no interior da Grécia. Todas as pessoas entrevistadas mostram raiva e desprezo pelo povo do país vizinho.

Entendemos que essas manifestações cotidianas são reflexo de séculos de ódios, e essa linha não poderá ser interrompida enquanto não houver um esforço das populações e, principalmente, dos seus governos, pela paz. A paz, é claro, passa necessariamente pelo reconhecimento dos erros do passado e pela tentativa de perdoar o que for possível. $\mathrm{O}$

\footnotetext{
352 Ibidem, p. 15.
} 
reconhecimento dos erros do passado não apenas do lado turco, mas também dos outros lados. Armênios e gregos também cometeram erros que precisam ser reconhecidos, embora seja senso comum que o peso maior está do lado turco. Essas pessoas ainda trabalham com a visão do outro como "o bárbaro":

"A barbárie resulta de uma característica do ser humano; aparentemente, seria ilusório esperar que, um dia, ela possa ser definitivamente eliminada. Portanto, para nós, a barbárie não corresponde a um período específico da história da humanidade, antiga ou moderna, nem a qualquer população que ocupasse uma região particular do planeta: ela está em nós, assim como nos outros; nenhum povo, nem indivíduo, está imunizado contra a possibilidade de executar atos bárbaros. O homem pré-histórico que mata o semelhante da grota vizinha, Caim que assassina Abel, o tirano contemporâneo que tortura seus adversários - todos participam do mesmo instinto de barbárie, a do sentimento de rivalidade e índole assassina que nos leva a recusar aos outros o direito de acesso às alegrias e aos bens que são objeto de nosso desejo.",353

Uma coisa é certa, neste mundo de tantas incertezas: não haverá paz e respeito ao Outro enquanto os erros do passado não forem reconhecidos e perdoados.

$\overline{353}$ TODOROV, Tzvetan. O medo dos bárbaros - para além do choque das civilizações. Petrópolis, Vozes, 2010, p 31-32. 


\section{CONSIDERAÇÕES FINAIS}

Com base na reconstituição histórica e historiográfica que marca a polêmica sobre o genocídio praticado contra os armênios e gregos entre 1914 e 1923 podemos afirmar que ainda, em pleno século XXI, persistem versões que procuram manipular os fatos históricos de forma a negar a ocorrência de um genocídio. Obviamente que não compartilhamos destas versões, mas não podemos ignorá-las, até mesmo como uma forma estratégica para minimizar ou anular contra focos produtores do negacionismo. Consideramos que a região em que se desenrolaram os acontecimentos, no caso o Império Otomano, foi, desde sempre, um território disputado e convulsionando por vários grupos comprometidos com o Poder e um pensamento intolerante para com as minorias. Não devemos nos esquecer, que interfere, também, o fato desta região ter sido o berço de inúmeras civilizações cujas histórias se superpõem dificultando afirmar qual dessas culturas têm, de fato, o "direito original" sobre a terra. Ainda assim, se insistirmos em designar um 'habitante original', a escolha recairia necessariamente sobre persas, gregos, sassânidas, armênios, romanos e mais alguns. Os turcos, com certeza, não figuram entre os primeiros habitantes da Anatólia, pois sua primeira aparição ocorre por volta do ano 800 d.C..

Desde a antiguidade e até meados do século XVIII, a região foi regida por enormes impérios, cujos governantes pouco sabiam do que se passava com os povos e regiões vizinhas. Por tradição, a população deveria aceitar a vontade dos imperadores e aceitá-la sem contestação sob a ameaça da perda dos seus direitos, prisão ou morte.

Exemplo a ser observado é o poder comum que os imperadores dispunham de movimentar as populações de um lugar para outro de acordo com os interesses e acordos políticos, como se verifica desde os tempos dos romanos. Outra situação exemplar da disposição popular em não enfrentar as ordens superiores é o Devshirme. Esta prática, muito utilizada desde que os otomanos começaram a ganhar terreno outrora bizantino, consistia no recolhimento de meninos de famílias cristãs, que nunca mais voltariam a vê-los, perdendo-os para sempre. Por conta desta apropriação, a maioria odiava profundamente o sultão. Alguns gregos ainda hoje se lembram dessa prática ao tentar explicar a razão para o ódio atual entre gregos e turcos. Centenas de milhares de meninos cristãos 
foram convertidos ao islamismo e serviram aos sultões durante os quatro séculos de dominação otomana, sem grandes protestos da população.

A retrospectiva histórica que apresentamos também nos leva a compreender que as diferenças religiosas faziam vítimas mil anos antes da ocorrência do genocídio contra os armênios e os gregos. As religiões nascentes faziam adeptos convictos, dispostos a morrer em nome da fé. E cada ramificação criava grupos ainda mais convictos, como aconteceu com os bizantinos monofisitas, diofisitas e a Igreja Armênia. De certa forma, esse movimento se repete hoje no Islã, entre os sunitas e os xiitas. São fendas profundas que dividem esses povos, ainda que se reconheçam como cristãos ou muçulmanos. Querelas da intolerância enraizada na mentalidade atrofiada pelos mitos políticos e pelo ódio sem limites.

Estes fatos repercutiram na política de subsistência utilizada pelas minorias durante o Império Otomano. A historiografia cita os armênios como o "millet fiel”, o que necessariamente coloca os demais millets como desleais, ou pelo menos, não tão confiáveis. Implica em disputas entre os millets, que unidos teriam sido muito mais fortes. Essa divisão ainda pode ser notada nos dias atuais, quando um pesquisador de renome, como Israel Charny, refere-se às disputas entre os seus pares pela "posse" da desgraça. Olhando tais interpretações com o devido distanciamento, essa disputa, - que poderia ser hilária não fosse o peso que carrega - constatamos que elas dificultam a união das forças em nome do reconhecimento que buscam.

No caso dos armênios, que sempre estiveram divididos entre dois impérios, percebemos que tiveram de aprender a conviver com essa realidade, assim como com o fato de serem tratados um "estorvo" para ambos. Servir a dois senhores não é tarefa fácil, muito menos quando são inimigos. Ainda mais complicada é a tarefa do Patriarca desse millet, que deveria manter sob controle uma comunidade tratada de formas distintas, por exemplo, como armênios turcos e armênios russos. É natural que, com o tempo, começassem a surgir entre os armênios e os gregos, vozes insatisfeitas com essa condição de desigualdade. Apesar da imagem de tolerância sustentada pelos senhores otomanos, vimos que a vida para estes cidadãos de segunda classe não era fácil, ainda que, comparada com os demais países, oferecesse melhores possibilidades de sobrevivência. 
Certamente a condição de inferioridade à que eram submetidos incomodava e, a seu tempo, esse povo haveria de buscar por saídas de emergência.

Por outro lado, após seis séculos de expansão constante do Islã, parece natural que os otomanos estivessem habituados à manter uma certa postura de superioridade. Afinal, apesar de serem uma minoria no poder, o controle estava nas mãos dos sultões e suas cortes.

Ao serem derrotados em Viena, em 1683, quebrou-se o encanto e a Sublime Porta, o centro administrativo do Império, não tinha um plano B. Justamente no momento em que o mundo mudava de forma, o Império Otomano se estagnou. A decadência não demorou muito. Todos os esforços dos sultões e vizires resumiram-se a recolher os fragmentos de um império em desmoronamento.

Todas as revoltas nacionalistas que assolaram o império em tão curto período nasceram com a fraqueza do poder otomano. Enquanto a Sublime Porta manteve a cobrança de altos impostos, os povos dominados mantiveram as cabeças baixas, mas aguardando uma oportunidade para romper com a ordem estabelecida. Mas, as grandes potências europeias também estavam vigilantes aguardando o momento da partilha. É pouco provável que qualquer um dos povos que alcançaram sua independência durante o século XIX o tivesse feito sem o apoio dos 'grandes'. Nem mesmo as grandes fortunas de gregos e armênios, citadas diversas vezes durante este nosso estudo, teriam sido possíveis sem a interferência dos vizinhos europeus. A questão é que nenhuma dessas potências estava realmente interessada em ser solidária aos grupos espoliados. Estavam sim interessados em forjar alianças (como aconteceu com a França, Países Baixos, Reino Unido e Rússia), observar ou favorecer o desmantelamento do império para, em seguida, compartilhar da divisão dos despojos, pura e simplesmente.

Devemos considerar que as políticas imperialistas do final do século XIX e XX eram marcadas pela expansão e domínio territorial, cultural e econômico de uma nação sobre outras, ou sobre uma região ou várias regiões geográficas. $\mathrm{Na}$ maioria das vezes, estas práticas eram justificadas por visões etno-centristas e racistas, influenciadas pelo ascensão do nacionalismo que varreu vários países, dentre os quais o Império Otomano. Daí os conflitos étnicos e revolucionários que culminaram com os atos genocidas praticados pelos "Jovens Turcos". Nada justifica o assassinato de milhões de pessoas, qualquer que seja a causa. 
Não é por acaso que uma corrente de historiadores apontam o Congresso de Berlim (1877) como "ponto de virada" da sorte dos cristãos no Império Otomano. Nesse momento fica evidente para o sultão o quanto seus vizinhos cobiçavam os seus domínios, a ponto de "guerrearem" entre si, em público.

O Sultão do Império Otomano e Califa de todo o mundo muçulmano reagiu, provavelmente, com o objetivo de mostrar que ainda estava no comando. Por mais uma década, até 1908, o 'Sultão Vermelho' seguiu no comando driblando a cobiça e os interesses dentro e fora de suas fronteiras.

Aqueles que tinham, por tratado, o dever de proteger as minorias, esquivaram-se dessa responsabilidade, valendo-se de discursos evasivos, insensíveis aos mínimos direitos humanos. Da mesma forma como, ainda hoje, fogem da responsabilidade de pressionar as grandes nações à resolver esta querela e a condenar os perpetradores dos atos genocidas que marcaram o início do século XX. Raros são os autores que comentam, e mesmo assim superficialmente, sobre a responsabilidade e o silêncio das Potências. Evitam discutir e a ouvir as vozes que questionam se a Turquia é ou não culpada, deixando-se levar por interesses políticos e econômicos imediatos. À Inglaterra, à França, à Rússia, não se imputa nenhuma culpa. Pelo menos, a França e a Rússia tiveram a hombridade de reconhecer o genocídio. A Inglaterra prefere não tocar nesse assunto.

Como foi dito diversas vezes, as mortes de armênios e gregos, as deportações e a ocupação de suas casas nunca foram negadas. Os números podem ser questionados, mas o governo turco reconhece que muitos, principalmente armênios, morreram nos anos de 1914 a 1916. Só não reconhece, o que é fundamental, que houve intenção premeditada por parte do Estado de incitar as matanças. Fundamenta sua argumentação (negativa) em declarações vazias, como o fato de terem apenas enviado aquelas famílias para outro lugar, prática ancestral utilizada em várias ocasiões. É inaceitável, para qualquer cidadão que preze os ideais de justiça, verdade e dignidade humana, que um líder político afirme que autorizou "apenas a deportação e não o massacre". Ou seja, somente pela Lei de Deportação, cuja autoria o governo reconhece, o Estado turco já deveria assumir a responsabilidade sobre as atitudes estatais que levaram à morte ou ao exílio milhares de pessoas.

Entretanto, pelo aspecto legal, a responsabilidade da Turquia depende, ainda, de "documentos comprobatórios" que provem que foi "genocídio" e não 
apenas deportação ou massacre, como querem fazer crer. Enquanto isso, armênios, gregos, turcos, assírios, curdos e outros, esperam para poder, simbolicamente, enterrar seus mortos ou conhecer seu passado... Estamos diante de um negacionismo alimentado por ódios seculares que mantêm a ferida aberta, diante de múltiplos diagnósticos, nem sempre confiáveis. Enquanto não houver pressão internacional e não forem apresentadas "provas irrefutáveis" da intenção estatal, a Turquia não precisará mudar o seu discurso negacionista. A humanidade como um todo, e não apenas os historiadores e mídia globalizada, têm aqui um importante papel de fazer cumprir com o direito à verdade e o direito à memória, valores universais tão caros aos Direitos Humanos. 


\section{FONTES}

\section{Testemunhos}

HORTON, George. The Blight of Asia, London, Sterndale Classics, 2nd Ed., 2008

MORGENTHAU, Henry. Ambassador Morgenthau's Story. New York, Doubleday, Page \& Co., 1918.

\section{Iconografia}

1 - Mapa do Oriente Próximo em 540 a.C. Derived from Image:Oriente Medio 600 dC (vacío).svg; modified to follow the map of the Achemenid empire of Persia - 559-480 BC in the Concise Atlas of World History (Andromeda, 1997). Fonte de internet: http://commons.wikimedia.org/wiki/File:Ancient_near_east_540_bc.svg

2 - Império Romano em 116 d.C. Fonte de internet: http://www.romanempire.net/maps/empire/extent/trajan.html

3 - Império Persa 539 a.C. fonte de internet: http://www.ushistory.org/civ/4e.asp

4 - Conquistas Otomanas de internet: http://www.theopavlidis.com/MidEast/part50.htm

5 - Perdas de território otomano Séculos XIX e XX. Fonte de internet: http://westernciv2.umwblogs.org/2010/11/21/maps-of-nations-during-the-consolidationof-nation-states/

6 - "Abdul Hamid - Band de pirates - o desmembramento do Império Otomano" - Em exibição no Museu da Torre Branca, Thessalônica. Início do século XX. Reproduzido por Ligia Sanchez, 2009.

7 - O Estado Grego independente em 1829. Intervenção nossa sobre mapa atual, disonível na internet em: www.maps.google.com

8 - Composição etnológica da Asia Menor e região, antes de 1910. fonte de internet: http://upload.wikimedia.org/wikipedia/commons/7/75/AsiaMinor1910.jpg

9- Sultão Abdul Hamid II fonte de internet: http://www.globalsecurity.org/military/ world/europe/ot-sultan-abdul-hamid-ii.htm

10- "Massacres em Adana, Abril 1909: "crianças armênias cuja carne foi decepada com tesouras de tosquia e cujos tendões dos joelhos foram cortados".De Ernst Jäckh, The Rising Halfmoon. Berlin-Schöneberg, 1911. (Cortesia de Informations-undDokumentationszentrun Armenien, Berlin) apud Balakian, Peter. The Burning Tigris - The Armenian Genocide and America's Response. New York, Perennial Ed., 2003

11 - Da esquerda para a direita: Talaat Pasha, Djemal Pasha e Enver Pasha, os líderes do Cup de 1913 a 1918 Fontes de internet: http://www.evi.com/q/facts_about_mehmed_talat_pasha; http://www.psywarrior.com/WWIAllies.html;http://www.wereldoorlog1418.nl/gallipoli/buite nlandse-inmenging/

12- Caravana de deportados armênios de Harput sob vigilância armada, maio de 1915. A Fotografia foi tirada por um comerciante alemão, de sua janela. (Cortesia de doador anônimo 
para o projeto SAVE) apud Balakian, Peter. The Burning Tigris - The Armenian Genocide and America's Response. New York, Perennial Ed., 2003

13 - Armênios deportados. Armin T. Wegner, Wallstein Verlag, Germany, 1915. Arquivo Genocide museum Yerevan - http://www.genocide-museum.am

14 - Armênios durante as deportações. Library of Congress Prints and Photographs Division Washington, D.C. 20540 USA. Sem data. http://hdl.loc.gov/loc.pnp/cph.3a48241.

15 - Criança armênia morta de fome. Armin T. Wegner, Wallstein Verlag, Germany, 1916. Arquivo Genocide museum Yerevan - http://www.genocide-museum.am

16 - Restos mortais de armênios queimados vivos em carro de boi em Aly-Zrna. Arquivo do Genocide Museum Yerevan, s. d. - http://www.genocide-museum.am

17 - Oficial turco provoca crianças deportadas famintas com um pedaço de pão. 1915 Collection of St. Lazar Mkhitarian Congr., http://www.armgate.com/genocide/pictures/stlazar/

18 - Telegrama do embaixador americano Morgenthau ao Secretário de Estado, 16 de julho de 1915 (National Archives, State Deptartment, Record Group 59.867.4016/76), apud Balakian, Peter. The Burning Tigris - The Armenian Genocide and America's Response. New York, Perennial Ed., 2003

19 - Quarenta armênios mortos em massacre na Asia Menor em Fevereiro de 1919. Arquivo da Library of Congress Prints and Photographs Division Washington, D.C. 20540 USA

20 - Mustafa Kemal (Atatürk) Fonte de internet: http://www.quotecollection.com/imageview.php?img=mustafa-kemal-ataturk-2.jpg

21 - Divisão do território otomano segundo o Acordo Sykes-Picot. Disponível em: http://www.clas.ufl.edu/users/oren/inr4204middleeast.html

22 - A chegada das tropas gregas em Esmirna, a população saudando os marinheiros e os protestos turcos. Fotografias reproduzidas do documentário Smyrna - The Destruction of a Cosmopolitan City 1900-1922, de Maria Iliou. Realizado pelo Proteus Archive Preservation Project, 2011

23 - Esmirna em chamas. Fotografia reproduzida do documentário Smyrna - The Destruction of a Cosmopolitan City 1900-1922, de Maria Iliou. Realizado pelo Proteus Archive Preservation Project, 2011.

24 - Porto de Esmirna em chamas repleto de refugiados em pânico, s.d. AGMI Collection, em exposição online no site do Museu do Genocídio em Yerevan. http://www.genocidemuseum.am/eng/online_exhibition_16.php

25 - Homens armênios e gregos presos e mandados para o exílio, Esmirna, Setembro, 1922. AGMI collection. Disponível online em http://www.genocidemuseum.am/eng/online_exhibition_16.php

26- O primeiro-ministro húngaro Conde Betlem e primeiro-ministro grego Venizelos, com Kemal Atatürk diante da Assembléia. (29 outubro de 1930). A fotografia está em exibição no museu da Casa de Atatürk em Thessalônica, Grécia e disponível online em http://www.isteataturk.com Adresinden 01.06.2013 Tarihinde Yazdırılmıştır.

27 - Demolição do Monumento à Humanidade, de Mehmet Aksoy, em Kars. De acordo com o escultor, sua obra mostra a dor da divisão entre Turquia e Armênia e promove a paz, irmandade e reaproximação entre os dois países. Imagem disponível em http://www.armenianweekly.com/2011/05/11/ucube-decapitated-in-kars/ 


\section{Filmes}

ILIOU, Maria. Smyrna - The Destruction of a Cosmopolitan City 1900-1922. Documentário realizado pelo Proteus Archive Preservation Project. 2011

DINÇ, Nefin. The Other Town - why do nations clash?. Documentário. 2011.

\section{Apresentação}

The Turkish crime of our century. Asia Minor Refugees Coordination Committee. 1985. Apresentação em Cd rom - acervo Biblioteca Central da FFLCH - USP 


\section{BIBLIOGRAFIA}

\section{Obras Específicas}

ABBOTT, George Frederick. Greece and the Allies 1914-1922. Domínio público. (Livro eletrônico)

AKÇAM, Taner. A Shameful Act. Translated by Paul Bessmer. New York, Metropolitan Books, 2006

ALAYARIAN, Aida. Consequences of Denial - The Armenian Genocide. London, Karnac Books, 2008. (Livro eletrônico)

ARRUDA, José Jobson de A. História Antiga e Medieval. São Paulo, Ática, 1982.

BALAKIAN, Peter. The Burning Tigris - The Armenian Genocide and America's Response.

New York, Perennial Ed., 2003

BLOXHAM, Donald. The Great Game of Genocide - Imperialism, Nationalism and the Destruction of the Ottoman Armenians. New York, Oxford University Press, 2005.

BREWER, David. Greece, the Hidden Centuries - Turkish rule from the fall of Constantinople to Greek Independence. New York, I.B.Tauris, 2010.

CAMERON, Averil, ed.. The Cambridge Ancient History - vol 14 - Late Antiquity: Empire and Sucessors, A.D. 425-600. Cambridge, Cambridge University Press, 2008.

CLARK, Bruce. Twice a Stranger - The Mass Expulsions that Forged Modern Greece and Turkey. Cambridge, Harvard University Press, 2006

CLOGG, Richard, A Concise History of Greece. 2nd Ed. Cambridge, Cambridge University Press, 2002.

DEMANT, Peter R. O Mundo Muçulmano. São Paulo, Ed. Contexto, 2004.

DOBKIN, Marjorie H. Smyrna 1922, The destruction of a City, New York, Newmark Press, 1998.

FERRO, Marc. Os Tabus da História - A Face Oculta de Acontecimentos que Mudaram o Mundo. Rio de Janeiro, Ediouro, 2002.

HALDON, John. The Palgrave Atlas of Byzantine History. New York, Palgrave Macmillan, 2005.

HOFMANN, Tessa; BJORNLUND, Matthias; MEICHANETSIDIS, Vasileios. The Genocide of Ottoman Greeks - Studies on the State-Sponsored Campaign of Extermination of the Christians of Asia Minor, 1912-1922 and its Aftermath: History, Law, Memory. New York, Melissa International Ltd, 2011.

IORDANIDOU, Maria, Loxandra, Barcelona, Ed Lúmen, 2000.

JONES, Adam, Genocide, a Comprehensive Introduction. New York, Taylor \& Francis Group e-library, 2006

JONES, AHM. The Later Roman Empire, 284-602, vol 1. Baltimore, University of Oklahoma Press, 1964.

LEWIS, Bernard. The Emergence of Modern Turkey. 3a. Ed. New York, Oxford University Press, 2002.

The Jews of Islam. Princeton, Princeton Univ. Press, 1984.

LEWIS, David Levering - O Islã e a formação da Europa. Amarilys, Barueri, 2008.

LEWY, Guenter. The Armenian Massacres in Ottoman Turkey. Utah, University of Utah Press, 2005.

MANGO, Andrew, Atatürk - the Biography of the Founder of Modern Turkey, New York, The Overlook Press, 2002.

MILLER, Donald. E; Miller, Lourna T. Survivors - An Oral History of the Armenian Genocide. Berkeley, University of California Press, 1999.

PASCHOAL, Erlon (trad.) Um Genocídio em Julgamento - o Processo de Talaat Pasha na República de Weimar. São Paulo, Paz e Terra, 1994 
SAPSEZIAN, Aharon. História Sucinta e Atualizada da Armênia. São Paulo. Emblema. 2010.

SHAW, Stanford, History of the Ottoman Empire and Modern Turkey 1808 - 1975 v. II. New York, Cambridge University Press, 1977.

SHIRINIAN, George N. (Ed). The Asia Minor Catastrophe and The Ottoman Greek Genocide - Essays on Asia Minor, Pontos and Eastern Trace, 1912-1923. Illinois, The Asia Minor and Pontos Hellenic Research Center, Inc., 2012

TODOROV, Tzvetan. O medo dos bárbaros - para além do choque das civilizações. Petrópolis, Vozes, 2010.

TOYNBEE, Arnold, BRYCE, James, Atrocidades Turcas na Armênia. São Paulo, Paz e Terra, 2003.

ZURCHER, Eric J. Turkey, a Modern History. New York, I.B. Tauris \& Co Ltd, 2005.

\section{Artigos}

ADALIAN, Rouben Paul. "Adana Massacre", disponível no site: http://www.armeniangenocide.org/adana.html

Adalian, Rouben Paul. "The Armenian Genocide: context and legacy". Disponível no site: http://www.armenian-

genocide.org/Education.56/current_category.117/resourceguide_detail.html

AKÇAM, Taner. "To talk about the genocide is good for Turkey". Disponível no site: http://www.balcanicaucaso.org/eng/Regions-and-countries/Turkey/Taner-Akcam-to-talk-

about-the-genocide-is-good-for-Turkey-118486

AKȘIN, I, 309-10, apud MANGO, Andrew. Atatürk - The Biography of the Founder of Modern Turkey.

ALGAN, Bulent. "The Brand New Version of Article 301 of Turkish Penal Code and the Future of Freedom of Expression Cases in Turkey". German Law Journal, v. 9, nº 12, pp. 2237-2238.

ARKUN, "Les relacions armeno-turques et les massacres de Cilicie", 64-6, apud BLOXHAM, Donald. The Great Game of Genocide - Imperialism, Nationalism and the Destruction of the Ottoman Armenians.

ASTOURIAN, "Genocidal Process", 61-2, 66-7, apud BLOXHAM.

BAYAR, Ben de Yazdim, vol. 5 p. 1576, apud AKÇAM, Taner. A Shameful Act.

BAYUR, Y.H., "Türk Inkilabi Tarihi", apud LEWIS, B. The Emergence of Modern Turkey.

BION, W. R. "Learning from Experience". London, Heinemann, 1962a, apud ALAYARIAN, Aida. Consequences of Denial - The Armenian Genocide.

BLISS, "Turkish Cruelties upon the Armenian Christians", p. 557, apud LEWY, Guenter. The Armenian Massacres in Ottoman Turkey.

BRUNEAU, Michel; PAPOULIDIS, Kiriakos. "Remembering the Genocide", in: HOFMANN, Tessa; BJORNLUND, Matthias; MEICHANETSIDIS, Vasileios. The Genocide of Ottoman Greeks - Studies on the State-Sponsored Campaign of Extermination of the Greeks.

BRYCE, James. "Transcaucasia and Ararat: Being Notes for a Vacation Tour in the Autumn of 1876", apud LEWY.

CHARNY, Israel W, "The Psychology of Denial of Known Genocides," in: CHARNY, ed., Genocide, 2:23 and LIPSTADT, Deborah E, Denying the Holocaust The Growing Assault on Truth and Memory (New York. The Free Press, 1993), p 217 apud SMITH, Roger W. "The Politics of Genocide and the Turkish Armenian Protocols". 
CHARNY, Israel W. "Integrity and Courage to Recognize All the Victims of a Genocide". In HOFMANN.

CHESTER, Colby, “Turkey Reinterpreted”, Current History, (September 1922), 944, apud BALAKIAN, Peter. The Burning Tigris.

COUFOUDAKIS, Van. "From Lausanne (1923) to Cyprus (2009): Turkey's violations of International Law and The Destruction of Historic Hellenic Communities", in: SHIRINIAN, George N. (Ed). The Asia Minor Catastrophe and The Ottoman Greek Genocide - Essays on Asia Minor, Pontos and Eastern Trace, 1912-1923.

CRISS, N. Bilge. "Istanbul under allied occupation 1918-1923". Leiden, E.J. Brill, 1999, apud ZURCHER, Eric J. Turkey, a Modern History.

DADRIAN, V. "A textual Analysis of the Key Indictment of the Turkish Military Tribunal Investigation the Armenian Genocide", in Armenian Review 44, no 1/173 (spring 1991), 3-4 apud BALAKIAN.

DADRIAN, Vahakn. "Warrant for Genocide", apud LEWY.

De ERNST, Jäckh, "The Rising Halfmoon". Berlin-Schöneberg, 1911. (Cortesia de Informations-undDokumentationszentrun Armenien, Berlin) apud BALAKIAN.

DE ZAYAS, Alfred. "The Ottoman Genocides in Light of the Genocide Convention", in: HOFMANN.

DES PRES," On Governing Narratives", apud BALAKIAN.

DROST, Peter, (1959) citado em JONES, Adam, Genocide, a Comprehensive Introduction. New York, Taylor \& Francis Group e-library, 2006

FARROKH, Kaveh, "Pan-Turanism Takes Aim at Azerbaijan: A Geopolitical Agenda". Disponível em: http://www.rozanehmagazine.com/NoveDec05/aazariINDEX.HTML

GRAVES, "Storm Centers of the Near East", apud LEWY.

HALO, Thea; JONES, Adam, "Notes on the Genocide of Christian Populations of the Ottoman Empire: Submitted in support of a resolution recognizing the Armenian, Assyrian and Pontic and Anatolian Greek Genocides of 1914-23" presented to the membership of the International Association of Genocide Scholars (IAGS), 2007, Sarajevo, Bosnia and Herzegovina, July 2007, apud CHARNY, Israel. "Integrity and Courage to Recognize all the victims of Genocide".

HEMINGWAY, Ernest. "In Our Time" apud DOBKIM, Marjorie. Smyrna, 1922 - The Destruction of a City.

HERMAN, J. "Trauma and Recovery", apud ALAYARIAN.

HOUSEPIAN, Marjorie, "The Unremembered Genocide" in Commentary (February, 1966) apud BALAKIAN.

HOVANNISIAN, Richard "Armenia on the Road to Independence", apud LEWY.

KARABEKIR, "Isitkal Harbimiz", citado em WALKER, Armênia, 305, apud BALAKIAN.

KENNEDY, Hugh. "Syria, Palestine and Mesopotamia". Cap 21b, in CAMERON, Averil, ed.. The Cambridge Ancient History - vol 14 - Late Antiquity: Empire and Sucessors, A.D. 425-600.

KUTAY,"Birinci", apud AKÇAM.

NURDOĞAN Taçalan, "Ege'de Kurtuluş Savaşi Başlarken" (Istambul, 1970) apud AKÇAM. ROUECH, Charlotte."Asia Minor and Cyprus". Cap. 21a, in CAMERON.

SALT, "Imperialism", apud AKÇAM.

SATOGLU Mithat citado em AKÇAM.

SIMSIR, "British Documents on Ottoman Armenians", vol 3, apud LEWY.

SMITH, Roger W., "The politics of Genocide and the Turkish-Armenian Protocols". Disponível em: http://www.zoryaninstitute.org/news.html

SMITH, Roger; MARKUSEN, Eric; LIFTON, Robert J. "Professional Ethics and the Denial of the Armenian Genocide". Holocaust and Genocide Studies, V9 N1 Spring 1995. 
SUNY, "Looking Toward Ararat", apud LEWY.

SUNY, Ronald G, "Empire and Nation: Armenians Turks and the End of the Ottoman Empire", Armenian Forum I, nº 2 (Summer 1998):33, apud LEWY.

STODDART, Philip (1963) "The Ottoman government and the Arabs 1911-1918: a preliminary study of Teşkilât-I Masusa", Tese de Doutorado (não publicada) Princeton, fl. 52, apud ZURCHER.

The Scotsman, 2 de julho de 1919, in http://www.umd.umich.edu/dept/armenian/bts/ OCTOBER_7-2-1919_TS_TurkishCourtMartialPublicProsecutorsSpeech.pdf

THOMPSON, R. W. "Armenia in the Fifth and Sixty Century" cap 22b, in: CAMERON.

VRYONIS, "The Mechanism of Catastrophe", apud COUFOUDAKIS, "From Lausanne (1923) to Cyprus (2009): Turkey's violations of International Law and The Destruction of Historic Hellenic Communities".

WALDER, 222, 229, apud MANGO.

WHITBY, Michael. "Armies and Society in the Later Roman World". Cap 17, in: CAMERON.

ZARAKOLU, Ragip, comunicado em Outubro de 2011 para a premiação do Freedom to Publish 2011, disponível em http://www.internationalpublishers.org/images/stories/FtP/ ReportsLetters/2011_report_on_the_freedom_of_publication_son.pdf

ZARAKOLU, Ragip, discurso durante o Seminário Internacional 95 Anos do Genocídio Armênio, realizado em 22-24 de Abril de 2010 no Departamento de História da Universidade de São Paulo.

ZÜRCHER, Erik Jan "The Ottoman Empire and the Armistice of Moudros". Disponível em: http://www.transanatolie.com/english/turkey/turks/ottomans/liddle.pdf

\section{Obras de Referência}

BLOCH, Marc - Apologia da História. Rio de Janeiro, Jorge Zahar, 2002.

CONSTANTINIDOU, Vassiliki T., Os Guardiões das Lembranças - memória e história de imigrantes gregos no Brasil. São Paulo, Ed. Do Autor, 2009.

CORDÁS, Táki Athanássios. Matzá com Moussaká - histórias de judeus e gregos. Cotia, Ateliê Editorial, 2007.

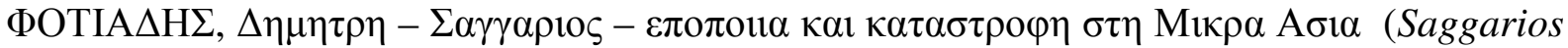

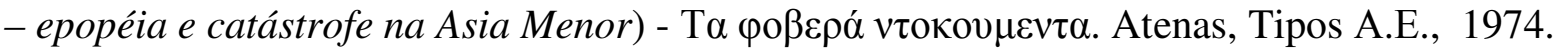

HOBSBAWM, Eric J. A Era dos Extremos: o breve século XX: 1914-1991. São Paulo, Companhia das Letras, 1995.

A Era dos Impérios. 1874-1914. Rio de Janeiro, Paz e Terra, 1989.

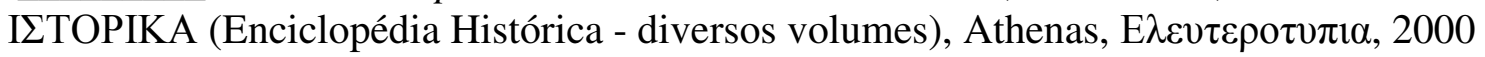

LEWIS, Bernard. O que deu errado no Oriente Médio. Rio de Janeiro, Jorge Zahar Ed., 2002.

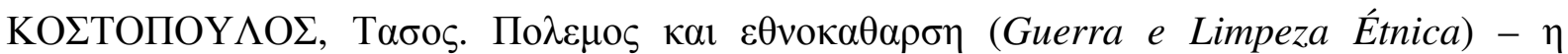
$\xi \varepsilon \chi \alpha \sigma \mu \varepsilon v \eta \pi \lambda \varepsilon v \rho \alpha \mu 1 \alpha \varsigma \delta \varepsilon \kappa \alpha \varepsilon \tau о \nu \varsigma \varepsilon \theta v i \kappa \eta \varsigma \varepsilon \xi о \rho \mu \eta \sigma \eta \varsigma 1912$ - 1922. Atenas, Ed. Biblorama, 2007.

MAZOWER, Mark. Salônica - cidade de fantasmas: cristãos, muçulmanos e judeus, 14301950. Tradução de Ivo Korytowski. São Paulo, Companhia das Letras, 2007.

SCHNERB, R. O Século XIX. História Geral das Civilizações, Vols XIII e XIV, São Paulo, Difel, 1977.

WATERFIELD, Robin. Athens - a history, from ancient ideal to modern city. Cambridge, Basic Books, 2004. 


\section{Sites}

http://an.uol.com.br/2003/set/21/0ane.htm

http://freedomforragip.wordpress.com/why-is-he-in-prison/

http://freedomforragip.wordpress.com/why-is-he-in-prison/

http://muqtafi2.birzeit.edu/en/InterDocs/images/280.pdf

http://sri000.wordpress.com/2013/02/26/the-conditions-dhimmis-have-to-live-by-under-

islamic-sacred-law-sharia/

http://www.armenia.com.br

http://www.armenian-genocide.org

http://www.armenian-genocide.org

http://www.armenianhouse.org

http://www.armenianpress.am

http://www.brasilturquia.com.br/index.php/a-turquia--informacoes-gerais/historia-otomano-

turquia-regiao/alegacoes-infundadas-dos-armenios

http://www.britannica.com/EBchecked/topic/931/Abdulhamid-II

http://www.dhimmi.org/

http://www.e-history.gr

http://www.ermenisorunu.gen.tr/english/relocation/law.html

http://www.fhw.gr/chronos/11/el/en/religion/conflict/index.html

http://www.firstworldwar.com

http://www.firstworldwar.com/timeline/1917.htm

http://www.globalsecurity.org/military/world/europe/carbonari.htm

http://www.greece.org/main/index.php?option=com_content $\& v i e w=a r t i c l e \& i d=580 \& I t e m i d=$ 820

http://www.greece.org/poseidon/work/articles/polemis_one.html

http://www.greek-genocide.org/

http://www.gregosnobrasil.com.br

http://www.historylearningsite.co.uk/sykes_picot_agreement.htm

http://www.historylearningsite.co.uk/woodrow_wilson1.htm

http://www.hri.org/docs/lausanne

http://www.internationalpublishers.org/images/stories/FtP/ReportsLetters/2011_report_on_the _freedom_of_publication_son.pdf

http://www.kultur.gov.tr

http://www.kultur.gov.tr/EN,32372/did-the-turks-engage-in-massacring-the-armenians-as-of-

.html

http://www.mfa.gov.tr

http://www.mfa.gov.tr/faq - Site oficial do Ministério de Relações Exteriores da Turquia

http://www.redstate.com

http://www.tallarmeniantale.com

http://www.tert.am/en/news/2013/05/02/newwales

http://www.transanatolie.com/english/turkey/turks/ottomans/liddle.pdf

http://www.umd.umich.edu/dept/armenian/facts/genocide.html

http://www.un.org

http://www.zoryaninstitute.org 